\title{
CALIFORNIA GRASSLANDS AND RANGE FORAGE GRASSES
}

ARTHUR W. SAMPSON

AGNES CHASE

DONALD W. HEDRICK

BULLETIN 724

MAY, 1951

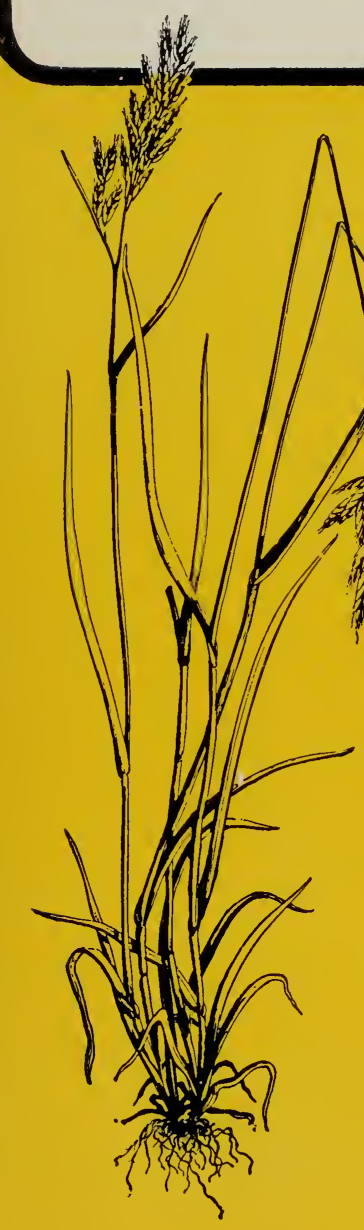

CALIFORNIA AGRICULTURAL EXPERIMENT

STATION - THE COLLEGE OF AGRICULTURE

UNIVERSITY OF CALIFORNIA 


\section{CALIFORNIA GRASSLANDS AND RANGE FORAGE GRASSES}

provides useful and technical information on the uncultivated or wild grasslands, and the native and naturalized range forage grasses of California. This bulletin will be helpful to you if you are among these readers:

1. Stockmen who have had some botanical training and who will want to use the illustrated keys and descriptions to determine the identity and the relative usefulness of the grasses growing on their range;

2. Range technicians and range appraisers who are chiefly concerned with management, evaluations, and economic considerations of the state's range lands; and

3. Students of range management and related fields whose knowledge of ecology, forage value, and taxonomy of the range grasses is an essential part of their training or official work.

\section{THE AUTHORS:}

Arthur W. Sampson is Professor of Forestry and Plant Ecologist in the Experiment Station, Berkeley.

Agnes Chase is Research Associate, U. S. National Herbarium, Smithsonian Institution; formerly Senior Agrostologist, U. S. Department of Agriculture.

Donald W. Hedrick is Research Assistant in the Department of Forestry; on leave from the Soil Conservation Service, U. S. Department of Agriculture.

Manuscript submitted for publication August 22, 1949. 


\section{CONTENTS}

PAGE

Introduction

Where Grasses Grow

Topography, climate, grassland soils, life zones, grasslands in relation to other plant associations

Plant Succession and the Climax Cover . . . . . . . . . 17

The Nutrition of Range Grasses . . . . . . . . . . . 18

Annual vs. perennial nutrition, nutrition and plant growth, nutrient deficiencies

Condition and Utilization of Grassland Ranges . . . . . . . 22

Range condition classification, range utilization standards

Artificial Range Reseeding

Characteristics of Grasses

Vegetative part, length of life and vegetative reproduction, flowers and seed

Important Range Forage Grasses (See Contents, Next Page)

Keys to tribes, genera, species; botanical distinctions, distribution, habitat, forage value, and reproduction of the more prominent individual species

A Checklist of California Grasses

Includes all grasses growing naturally in California, arranged by tribes and genera

Literature Cited

A List of Technical Words Used in This Bulletin, and Their Meanings 126

Index to California Range Forage Grasses .

Includes all grasses referred to in the section, "Important Range Forage Grasses" 


\section{IMPORTANT RANGE FORAGE GRASSES}

\section{CONTENTS TO MAIN DESCRIPTIVE SECTION, PP. 31-115}

Key to tribes, 33

Fescue-bluegrass-bromegrass tribe (Festuceae), 34

Bromegrasses (Bromus), 34

Fescuegrasses (Festuca), 42

Bluegrasses (Poa), 47

Saltgrasses (Distichlis), 53

Melicgrasses (Melica), 54

Mannagrass (Glyceria), 59

Orchardgrass (Dactylis), 60

Lovegrasses (Eragrostis), 61

Alkaligrass (Puccinellia) , 62

Wheatgrass and barleygrass tribe (Hordeae), 62

Wheatgrasses (Agropyron), 63 Wild-rye grasses (Elymus), 65

Squirreltails (Sitanion), 68

Bottlebrush (Hystrix), 69

Barleygrasses (Hordeum), 70

Ryegrasses (Lolium), 72

Goatgrass (Aegilops), 73

Oat tribe (Aveneae), 74

Wild oats (Avena), 74

Oatgrasses (Danthonia), 75

Hairgrasses (Deschampsia), 77

Junegrass (Koeleria), 79

Trisetum (Trisetum), 79

Tall oatgrass (Arrhenatherum), 81

Velvetgrass (Holcus), 81

Timothy tribe (Agrostideae), 82

Redtops (Agrostis), 83
Needlegrasses (Stipa), 86

Reedgrasses (Calamagrostis), 91

Timothy (Phleum), 95

Muhlygrasses (Muhlenbergia), 96

Alkali sacaton (Sporobolus), 99

Ricegrasses (Oryzopsis), 100

Threeawns (Aristida), 102

Drooping woodreed (Cinna), 103

Nitgrass (Gastridium), 104

Curly mesquite tribe (Zoysieae), 105

Big galletagrass (Hilaria), 105

Grama tribe (Chlorideae), 105

Gramagrasses (Bouteloua), 106

Sloughgrass (Beckmannia), 107

Bermudagrass (Cynodon), 107

Feather fingergrass (Chloris), 108

Canarygrass tribe (Phalarideae), 109

Canarygrass (Phalaris), 109

Sweet vernalgrass (Anthoxanthum), 110

Veldtgrasses (Ehrharta), 110

Millet tribe (Paniceae), 111

Dallisgrass (Paspalum), 111

Pacific panicum (Panicum), 112

Barnyard grass (Echinochloa), 112

Kikuyu grass (Pennisetum), 113

Sorghum tribe (Andropogoneae), 114

Cane beardgrass (Andropogon), 114

Johnsongrass (Sorghum), 114 


\section{CALIFORNIA GRASSLANDS AND RANGE FORAGE GRASSES}

THE GRASSES ARE BY FAR the most important forage plants occurring naturally on the ranges. Many broad-leaved herbs (forbs or weeds) and shrubs add to the natural range forage, but grasses probably supply the major sustenance for livestock on California range lands. The maintenance of a vigorous and luxurious stand of the better grasses goes hand in hand with a well-planned livestock production program.

Another important function of grasses is their capacity to protect the soil from excessive erosion. Soil well covered with grass absorbs rain or melting snow rapidly and resists the inroads of erosion to a remarkable degree. This is because the leaf blades and stems of a well-established grass area break the force of the individual raindrops, and the numerous fibrous roots bind the soil firmly. Runoff is held to a minimum on well-grassed lands. On the other hand, where overgrazing, especially of sloping areas, has resulted in exposing the soil to the elements, wind and water erosion may soon remove so much topsoil as to make regrassing difficult if not impossible.

\section{RESEARCH ON GRASSES}

Even though grass stands are usually highly nutritious and palatable, agricultural science has not overlooked the possibility of improving individual grass species or their variants. To this end, geneticists of the College of Agriculture of the University of California are striving to augment the grass forage of wild range lands through selective breeding and cross pollination $(35,55) .^{1}$

The grass family, like many other economically important plant groups, in-

"See "Literature Cited" for references made in the text by number. cludes a few troublesome species (22). Some cause mechanical injury to livestock because of the sharp or barbed awns of the mature seed heads, but may be good forage plants in the earlier growth stages. The awns become attached to the wool of sheep, and to the skin, nostrils, mouth, throat, and eyes of grazing animals generally, causing sores and occasionally death. Other troublesome species are those, such as the wild barleygrasses (Hordeum spp.) and the squirreltail grasses (Sitanion spp.), whose heads break up at maturity liberating several sharply barbed bristles. Goatgrass (Aegilops triuncialis), a relative of wheat, is a despised Mediterranean invader, its long rigid barbed bristles causing great suffering to cattle, sheep, and goats. A few common bromegrasses (Bromus spp.) of Mediterranean origin, notably ripgut grass (B. rigidus), also cause mechanical injury. The geneticists are hopeful of perfecting range species which may partly replace these mechanically troublesome species.

\section{HOW THIS BULLETIN IS ORGANIZED}

In presenting California grasses the authors first discuss where grasses grow. This is followed by considering the succession of plants on the range, and the "climax cover." Then comes a discussion of grass as forage, including the nutrition, utilization, and management of grasslands. With the foregoing as background material, the characteristics of true grasses are presented; and finally there is a discussion of the more important individual forage species. A checklist of the more than 400 grass species of the state is given as an appendix. 


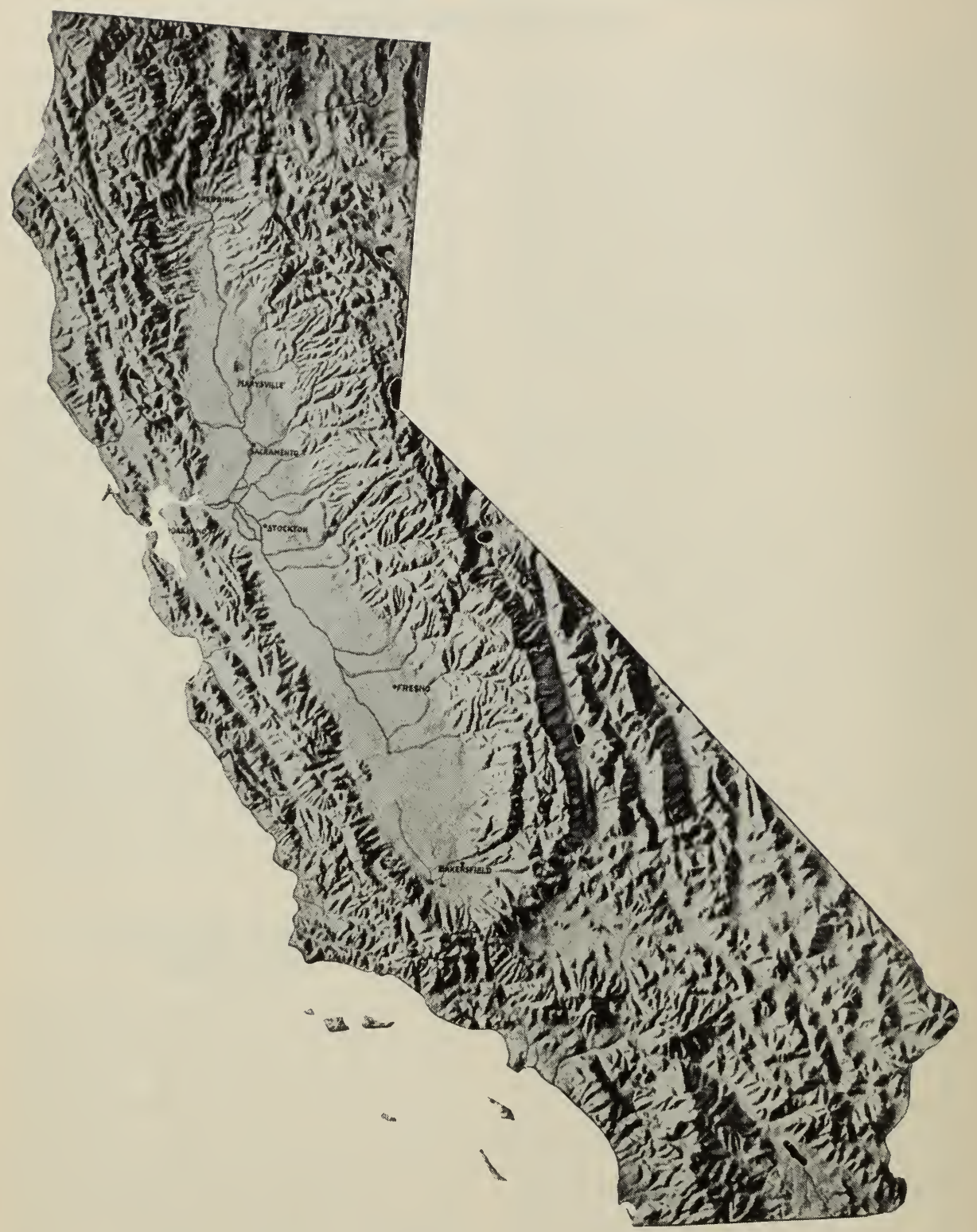

Fig. 1. Relief map of California showing topographical features. 


\section{WHERE GRASSES GROW}

The varied physiography of California largely determines the distribution, composition, and zonal relations of the grasslands and associated vegetation. The great range in elevation, the extremes of climate, and the variation in soils found within the state all influence the growth of grasses. If grasslands are to be grazed properly, effects of topography, climate, soil, life zone, and relation to other plant associations must be considered.

\section{TOPOGRAPHY}

The main topographic features are simple in broad outline but complex in detail. (Fig. 1.)

Mountain ranges along the eastern and western boundaries enclose the large Central Valley, which is bounded on the north by cross mountains between the Coast Range and the Cascades and on the south by the Tehachapi Mountains. A narrow coastal belt parallels the ocean, and east of the Sierra Nevada Range lies the high arid section of the Great Basin. The Colorado and Mojave deserts occupy most of the dry, barren area in southeastern California. Two large rivers drain the major portion of the state. The Sacramento River flows south through the northern half of the Central Valley and the San Joaquin flows north through the southern half. They converge near San Francisco Bay and empty into the ocean through the only large break in the Coast Range.

The Sierra Nevada Range along the eastern border is the highest mountain chain in the state, with elevations generally above 6,000 feet. The west slope of this range rises from near sea level and is dissected by numerous canyons and gorges leading into the Central Valley. In contrast, the Coast Range is interspersed by several large river valleys that drain into the ocean.

The Central Valley is some 450 miles long and averages about 40 miles wide.
The valley floor is covered with rich, alluvial, highly productive soils. Most of the valley land is cultivated or in irrigated pasture, but the more alkaline areas are in native grassland which is annually grazed.

Two smaller topographic units are found outside the main mountain chains. The high arid plateau lying to the east of the Sierra Nevada Range belongs to the Great Basin drainage area. This section is similar to much of Nevada and Utah in local relief and vegetation. Next to the ocean a narrow coastal plain, which widens out below Point Conception in Santa Barbara County, supports grasslands of local importance.

The deserts of California are found south of the Tehachapi Mountains and east of the Coast Range. The relief in this area is characterized by numerous low mountains and valleys with the only drainage outlets leading into the Colorado River. Except for irrigated sections this region is generally dry and barren.

\section{CLIMATE}

The ocean and the mountains are important influences on the climate of the state. The ocean modifies the temperature fluctuations along the coast and in some areas well inland. Indeed the high mountain chain along the eastern border serves as a barrier to air mass movement, which affects the continental climate of the interior United States. Together these influences produce an effect commonly referred to as a Mediterranean climate, which is characterized by cool rainy winters and warm dry summers. Division of the year into two well-defined seasons is a striking feature of the California climate. These unusual climatic conditions typical of the valley and foothill lands have encouraged the growth of winter annuals on some 20 million acres of grassland. Native and introduced annual grasses and forbs have become estab- 


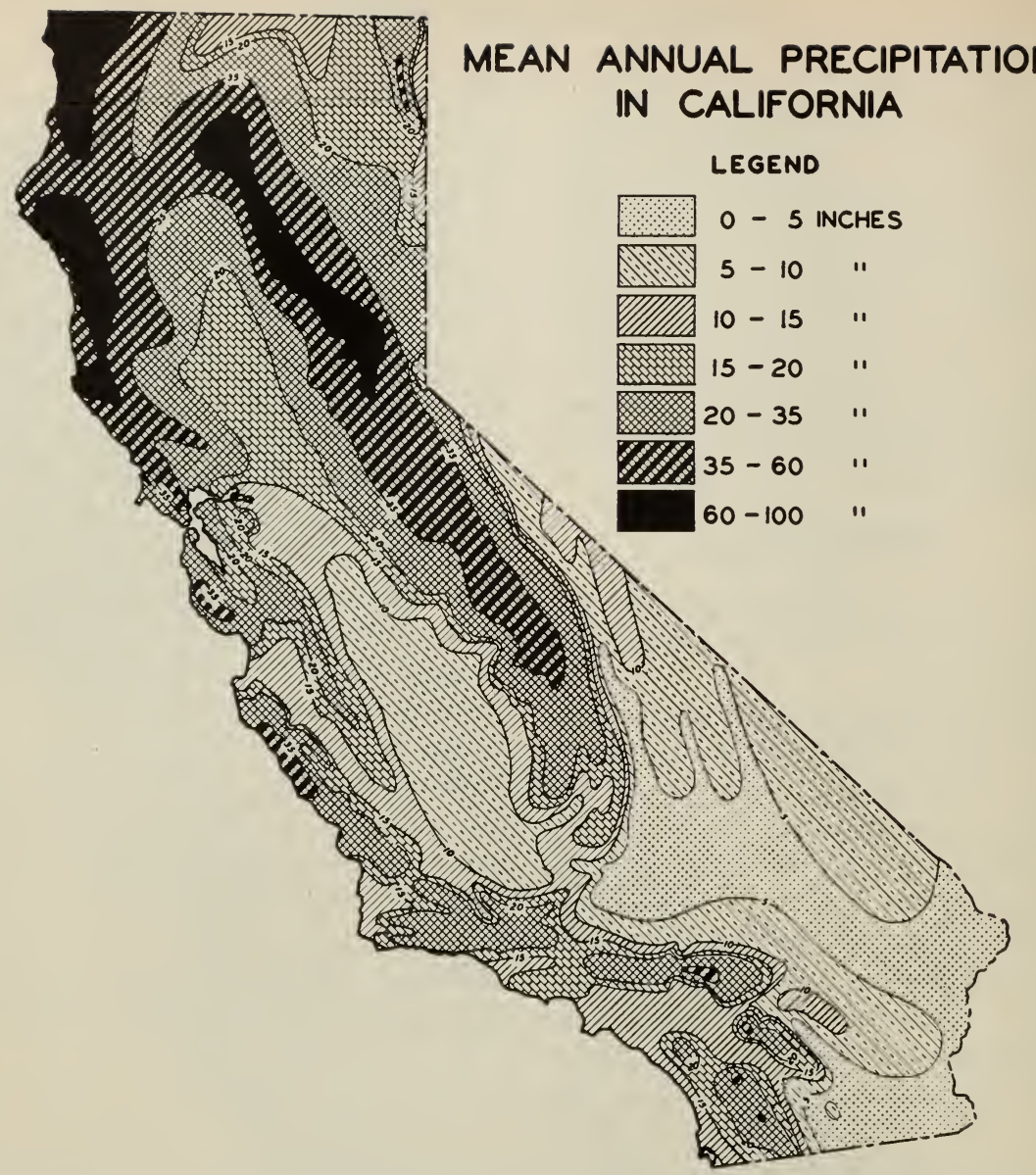

Fig. 2. Mean annual precipitation in California. (After Crawford and Hurd, Calif. Agr. Expt. Sta.

Bul. 654.)

lished over this vast area to the near exclusion of the formerly more abundant perennials.

Precipitation: The rainfall generally decreases from west to east (an exception being in the northern Sierras), and from north to south (fig. 2). Comparison of fig. 2 with the topographic map (fig. 1) shows a definite correlation between elevation and amount of precipitation.

The amount and the seasonal distribution of precipitation markedly affect the composition of California grasslands. Rainfall areas of 17 inches or less a year (occurring in winter) are generally dominated by annuals, whereas in the high mountain areas of heavier precipitation perennial grasses are abundant. In California the greatest grassland area lies between sea level and about 4,000 feet. Within this range, rainfall varies from less than 10 inches in the southern part of the state to more than 40 inches in the northern foothills. A greater percentage of perennials is accordingly found in the higher elevations receiving more precipitation. Perennial grasses also occur sparingly on desert areas receiving limited amounts of summer rainfall.

Temperature: Spring and summer temperatures, and length of growing season (as affected by temperature), are 
(Note: no attempt has been made to classify the large number of recent alluvial soil series here, since most of those soils are in use for cultivated crops.)

\section{a. Upland grassland soils}

1. Prairie-like soil is dark in color, of high organic content, and slightly acid. This soil constitutes the better grasslands of the state. Cayucos, Los Osos, Colma, and Sweeney soil series belong to the group. They are commonly found near the coast.

2. Chernozem-like soils are of dark color, fairly high organic content, neutral surface with calcareous subsoil. They are good grassland soils, and are typified in the Altamont and Diablo soil series. They occur commonly in Contra Costa, San Benito, eastern Santa Clara and eastern Alameda counties.

3. Rendzina soils are calcareous and of dark color. They are usually good grasslands. Typical are the Ayar, Linne, and Zaca soil series. These soils commonly occur throughout the southern Coast Range of California in San Diego, Orange, Los Angeles, Ventura, and San Luis Obispo counties.

\section{b. Terrace grassland soils}

1. Prairie-like soils having dense subsoils. Although subject to serious erosion, they are fair to good grassland soils. They are illustrated by McClusky, Tierra, and Watsonville soil series. These soils occur along the coastal plain, principally in Santa Barbara, San Luis Obispo, Monterey, and Santa Cruz counties.

2. Chernozem-like soils having dense calcareous subsoils. These are usually good grasslands. Illustrations are those of the Montezuma, Porterville, Ambrose and Antioch soil series. These soils occur as terrace lands in the Coast Range valleys and in the Sacramento and San Joaquin valleys.

\section{c. Basin grassland soils}

These soils are formed under poor drainage. They are generally of clay texture, high in organic content, and have ample calcium carbonate. As a rule they are good grasslands. These soils are illustrated by Merced, Sacramento, Dublin, Clear Lake, Stockton, Pit, Conejo and Carson soil series. They occur in the Sacramento and San Joaquin valleys as well as a number of the intermountain valleys of the state.

d. Upland oak-grasslands

These are brown soils of about neutral reaction (noncalcic brown group) and are subject to considerable erosion. They are generally fair grasslands. They are illustrated by Vista, Fallbrook, Gaviota, Vallecitos and Contra Costa soil series. These soils occur throughout the eastern Coast Range and in southern California.

\section{e. Terrace oak-grasslands}

These brown soils are about neutral in reaction (noncalcic brown group) and are generally fair grasslands. They are illustrated by Ramona, Pleasanton, Hames, and Tehama soil series. These soils occur as terrace lands in many places throughout the state.

\section{f. Upland shrub-grasslands}

These are brown or desert-like soils of the lower rainfall region. They form the poorer grasslands and are quite erosive. These soils are illustrated by the Lassen, Caliente, and Kettleman soil series. They occur in the lower rainfall parts of the state, as in the southern San Joaquin Valley.

\section{g. Alkali lands}

These soils form the flat valley lands, and support alkali-tolerant plants which provide fair to good pasturage. These soils are illustrated by the Fresno, Pond, Canby, Lethent, and Solano soil series. They occur principally in the San Joaquin Valley.

${ }^{2}$ R. Earle Storie and Walter W. Weir: Manual for Identifying and Classifying California Soil Series. Published by Associated Students Store, University of California, Berkeley. 1948. 
are calcareous throughout. Even in the higher-rainfall areas, where some of the so-called "prairies" occur, the soils are typically more basic with increased depth, in contrast to good commercial timber soils which become more acid with depth. Otherwise stated, grasses do better where there is a supply of calcium. Grasses grow on much shallower soils than timber, assuming ample rainfall. Many of the good residual grassland soils of the state have a depth of only about two feet to bedrock. Also, many good grassland soils have claypan subsoils which are unsuited to timber and are of poor quality for orchard purposes. Many of California's imperfectly drained soils are satisfactory for grass production while of poor quality for timber and the growing of cultivated crops.

Effect of soil-forming factors on grassland soil characteristics: Soil-forming factors that contribute most to grassland soil characteristics are climate, parent material, and drainage.

Climate: The best grassland soils in California are those where the average annual rainfall is between 15 and 30 inches and where there is a mild temperate climate, such as that along the coast. Very high rainfall generally leaches the soil of its bases, making it strongly acid. There are, however, occasional areas of high rainfall where the soil may not be extremely acid because of the basic nature of the parent material and the young age of the soil.

Soil parent material has an important effect on many soil characteristics, such as soil texture and the amount of bases (e.g., calcium) in the resultant soil. Fine-textured parent material produces fine-textured soils, such as clay loams and clays, whereas the coarser-textured materials produce such coarse-textured soils as sands and sandy loams. Many good grassland soils come from the decomposition of shale rocks. The coarse-textured sandstones and granitic rocks produce poorer grassland soils. This is so because the soils from the coarse-textured materials have a lower water-holding capacity than those from the finer-textured parent materials. Many sedimentary types of rocks, as well as basic igneous rocks, liberate carbonates in the soil which are desirable for grass growth.

Drainage: Many soils occupying lowlying poorly drained positions are desirable for certain types of grasses. Such soils usually are of high water-holding capacity, of dark color, are high in organic content, and contain ample calcium carbonate. These are often called the "basin grasslands." They occupy the trough of the Sacramento and San Joaquin valleys, and smaller valleys of the state where there is stream overflow.

Resistance of grassland soils to grazing pressure and erosion: This depends to a large extent on the type of soil, the slope, and the rainfall. Dark colored, fine textured, upland soil types of potentially high grazing capacity, such as Cayucos clay; Los Osos clay; Colma loam; Altamont clay loam; and Diablo clay; (group $a$ ), will stand considerable pressure without much erosion, whereas the sandier soil types occupying sloping areas will not stand much grazing pressure and will erode badly if the cover is scanty.

Most of the soil types belonging to group $d$ (noncalcic brown group), which occur with about 12-20 inches annual rainfall, such as Vista sandy loam, Vallecitos stony loam, and Gaviota sandy loam, do not stand much grazing pressure. They are fairly erosive. Most upland soils occurring under low rainfall have a low grazing capacity, and are readily erosive if grazed too closely.

Soil profile also plays an important part in erosion. Permeable profiles will absorb the rainfall, whereas those having slowly permeable subsoils will only absorb the rainfall slowly, and the excess will run off causing erosion on those areas with little vegetation. 


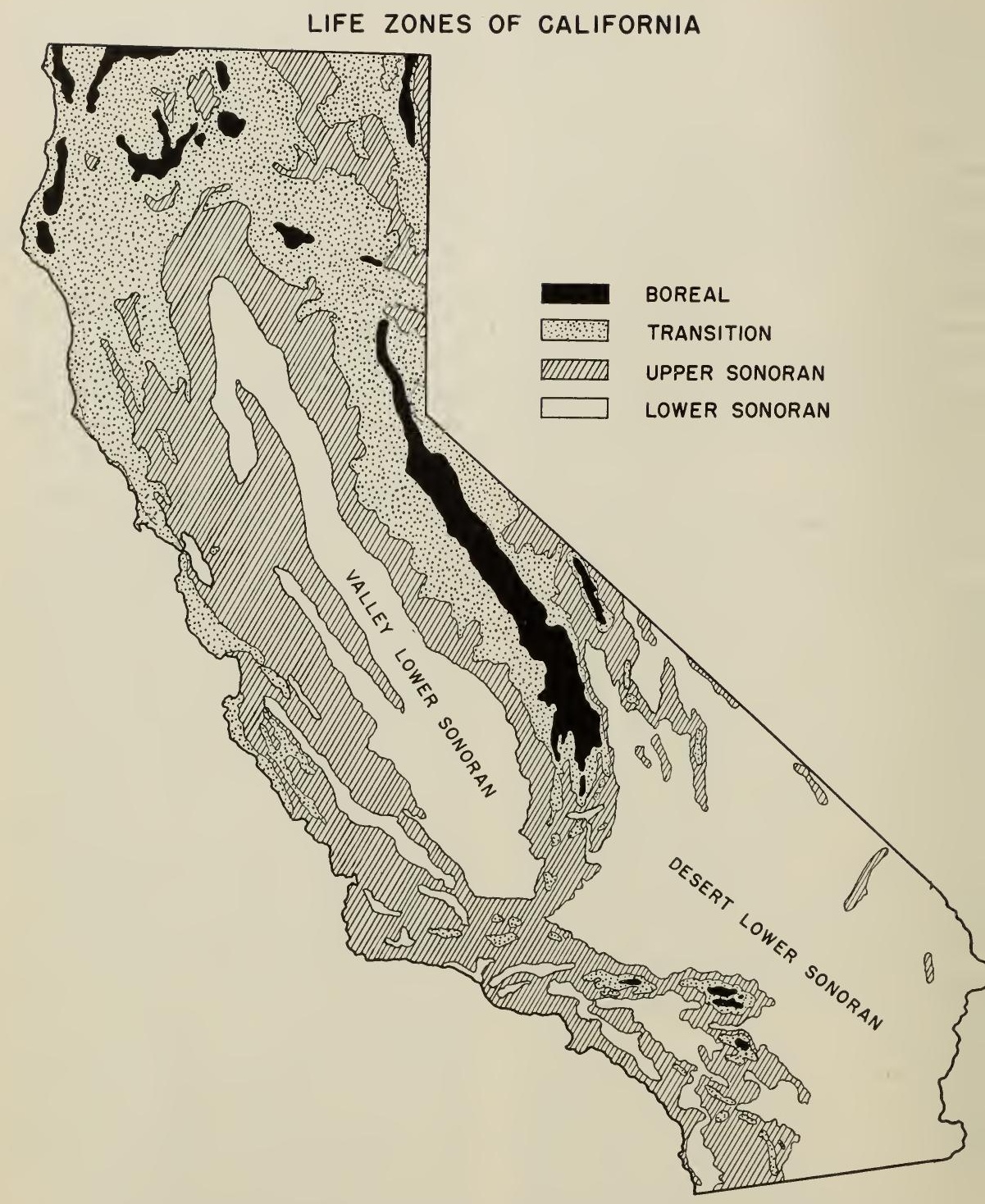

Fig. 4. Life zones of California. (After Dr. Joseph Grinnell, Calif. Univ. Zool. Pub. 40(7).) 


\section{LIFE ZONES}

Grasslands, like other areas supporting different vegetal growth forms, reflect the environmental conditions under which they develop. Accordingly, it is desirable in delimiting grassland associations to recognize the presence of the four life zones which occur in the state. (Fig. 4.) Considered in order of elevation these are: Lower Sonoran, Upper Sonoran, Transition, and the Boreal region (embracing the Canadian, Hudsonian, and Alpine-Arctic zones). Reference will occasionally be made to these zones in discussing grassland associations and the individual grass species.

1. The Lower Sonoran zone covers about 36.5 per cent of the state. This area includes lower elevations of the Central Valley and desert regions where temperatures are high and rainfall is low. In the southeastern desert the Lower Sonoran zone extends from below sea level to about 5,000 feet, whereas in the Central Valley it is confined to areas below 500 feet. Vegetation in this zone is typically sparse. The cover usually consists of scattered desert shrubs and a few species of annual and perennial grasses. Except for irrigated pastures, forage production on grasslands in this zone is extremely low. Grazing is confined chiefly to the winter and early spring months.

2. The Upper Sonoran zone covers approximately 33 per cent of California. It lies immediately above the Lower Sonoran zone and extends to elevations of $3,000-5,000$ feet. This belt includes the foothill and valley lands where mean precipitation is slightly higher and the temperature somewhat lower than the zone below. Native and introduced annuals predominate. In the chaparral cover of this zone annual and perennial grasses and forbs form much of the understory.

3. The Transition zone contains the commercial timber area of California and occupies some 26 per cent of the total land area of the state. Along the north coast this zone reaches from sea level to about 6,000 feet, whereas inland it occupies a narrower elevational range between 2,000 and 5,000 feet just above the Upper Sonoran zone. The Transition zone includes the relatively humid redwood and Douglas fir areas in the northwestern part of the state, and the more arid ponderosa pine and mixed conifer area of the Sierras. Rainfall is higher and temperatures are lower than in the zone below. An appreciable amount of summer grazing is provided by grasses which occupy the meadows and parks in open timber stands.

4. Boreal zone: Immediately above the Transition zone is a relatively small area comprising three zones, the Canadian, the Hudsonian, and the AlpineArctic. These are here treated together under the designation "Boreal." This combination of zones makes up only about 4.5 per cent of the area of the state. Of them, the Canadian life zone is best represented. It borders the upper limits of the Transition zone and is characterized by Jeffrey pine and true fir. It extends up to approximately 7,000 feet. The Hudsonian zone covers the timberline area between 7,000 and 9,000 feet. Lodgepole and whitebarked pine are typical indicators of this belt. The true AlpineArctic zone occurs above timberline and includes all of the highest areas, extending upward from about 9,000 feet. It is characterized by spike trisetum, shorthair sedge, and various forbs with colorful blossoms. The Boreal zones are characterized by low temperatures and precipitation which comes mainly as snow. Grazing is limited to a short mid- and late-summer period, the subalpine grasslands and meadows furnishing most of the forage. Most of the Boreal zone lies within the national forest and park boundaries. Because of the rugged topography much of this zone is best adapted to sheep grazing. 
CALIFORNIA GRASSLANDS AND ASSOCIATED VEGETATION

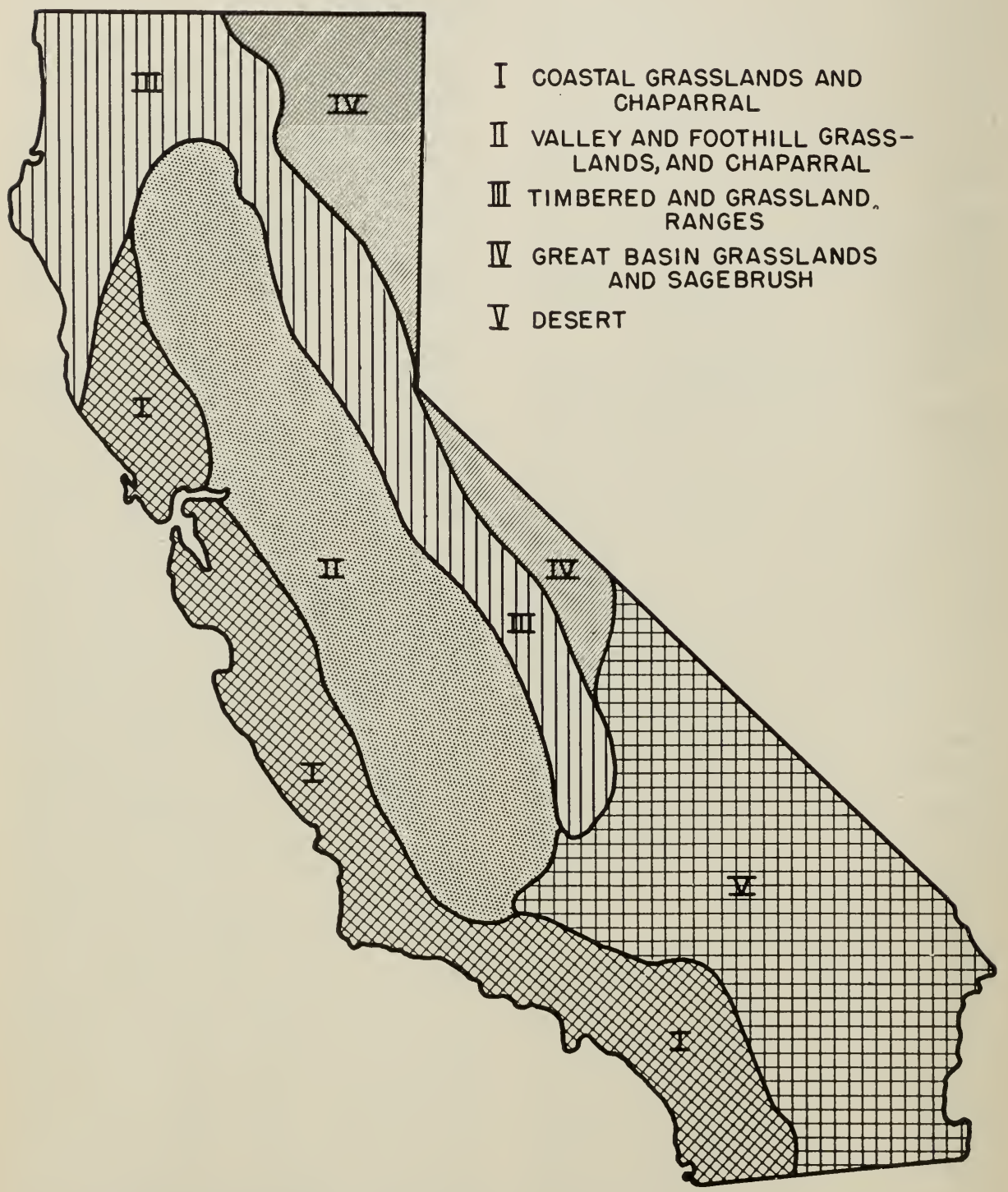

Fig. 5. General distribution of California grasslands and associated vegetation. 
GRASSLANDS IN RELATION TO OTHER PLANT ASSOCIATIONS

A large part of the natural vegetation of California has been mapped and classified by the Forest and Range Experiment Station of the U. S. Forest Service. A map of the vegetation prepared under the direction of A. E. Wieslander (29) has been adapted (fig. 5) to show the general distribution of California grasslands and associated vegetation.

The area dominated by ponderosa (yellow) pine, which occupies lands of intermediate elevations, includes a large acreage of timber-grassland in the northern counties of the state. It composes the driest of the timber associations and is confined to the Arid-Transition life zone (fig. 4). The parks, glades, and meadows within open stands of ponderosa pine are valuable for early summer grazing in the eastern portion of the Coast Range, the southern Cascades, and the western part of the Sierra Nevada. Some of the more common perennial grasses of this open timber country are: smooth wildrye (Elymus glaucus), needlegrasses, also called stipas (Stipa spp.), Idaho fescue (Festuca idahoensis), squirreltail (Sitanion hystrix), Junegrass (Koeleria cristata), tufted hairgrass (Deschampsin caespitosa), and bluegrasses (Poa spp.) (62).

The area known as the "redwcod belt" is located along the relatively moist coast north of San Francisco Bay in theHumidTransition life zone (fig. 4). Virgin forests or dense stands of second-growth redwood produce little if any grazing. Accordingly, grasslands are restricted to portions of the cut-over burned-over, and cleared areas, some of which are reseeded to cultivated species.

The belt composed of Douglas fir and associated fir species borders the redwood belt along the coast and lies above the ponderosa pine in the interior. The firs occupy an intermediate position in the Transition life zone between the cool, moist habitat of the redwoods and the dry, warm sites supporting ponderosa pine. As in the redwood belt, grazing is here essentially confined to openings in the timber stand.

The belt occupied by lodgepole pine and whitebark pine occurs in the high mountains of the Sierra Nevada just below timberline. This forest, lying wholly within the Boreal life zone, is intermixed with subalpine grasslands and is dominated by needlegrasses (Stipa spp.), bluegrasses (Poa spp.), greenleaf fescue (Festuca viridula), spike trisetum (Trisetum spicatum), hairgrasses (Deschampsia spp.), and sedges (Carex spp.). These grassland areas occur on glades of a few to many acres and furnish appreciable amounts of mid- and late-summer grazing, mostly on the national forests.

The forest composed of piñon pine and juniper occurs on elevated sites east of the Sierra Nevada divide in the AridTransition life zone. Here wheatgrasses (Agropyron spp.) and wild-rye grasses (Elymus spp.) are among the most abundant of the grasses, while Sandberg bluegrass (Poa secunda) and downy chess (Bromus tectorum) also furnish grazing.

The foothill region of woodland-grass, occupying intermediate elevations surrounding the Central Valley, lies almost entirely within the Upper Sonoran life zone. Although this belt is dominated by hardwoods, notably oaks, the understory is essentially herbaceous. Most of the forage is composed of annual species. The more important grasses are bromes (Bromus), wild oats (Avena), and fescues (Festuca). A few perennial needlegrasses (Stipa spp.) and oatgrasses (Danthonia spp.) are of local importance, but these probably contribute less than 5 per cent of the herbaceous cover over most of this region (3).

The largest area of open grassland in California lies along the edge of the Central Valley and surrounding foothills. It is principally in the Lower and Upper Sonoran life zones and is dominated by 
annual species. Nearly all the Central Valley was formerly grassland, but the development of California's great agricultural enterprise has left only a narrow fringe of grassland bordering the woodlandgrass association of the foothills. In fact, the only valley lands now remaining in grass are usually too alkaline for crop production. These alkali areas support nearly pure stands of saltgrass (Distichlis stricta) and alkali sacaton (Sporobolus airoides), which are grazed in late fall, winter, and early spring.

Extensive stands of chaparral occur in the Coast Range, mostly within the Upper Sonoran life zone. The grazing value of the area is largely determined by the amount of brush present. Dense, fully developed stands of chaparral provide little if any grazing, whereas open stands support considerable forage. The more common grasses of the chaparral areas are: foxtail fescue (Festuca megalura), red brome (Bromus rubens), silver hairgrass (Aira caryophyllea), and nitgrass (Gastridium ventricosum) (51). Needlegrasses (Stipa spp.) are occasionally abundant in localized areas.

Two sagebrush associations are found in California. Big sagebrush (Artemisia tridentata) occurs east of the Sierras in the Upper Sonoran and AridTransition life zones. Coastal sagebrush (Artemisia californica) also occurs in the Upper Sonoran life zone, but is confined to a strip near the coast, chiefly in the southern Coast Range. The understory of big sagebrush consists principally of perennial grasses. Big sagebrush lands in good condition are occupied by wheatgrasses (Agropyron spp.), wild-rye grasses (Elymus spp.), and Indian ricegrass (Oryzopsis hymenoides). Where stands of these grasses have been depleted by excessive grazing, Sandberg bluegrass (Poa secunda), Nevada bluegrass ( $P$. nevadensis), and downy chess (Bromus tectorum) provide most of the forage. In the coastal sagebrush areas annual grasses predominate but some perennial bunch- grasses, notably needlegrasses (Stipa spp.) and California oatgrasses (Danthonia californica and $D$. californica var. americana), occur where the sagebrush is sparse.

Desert grasslands are confined to the southeastern portion of the state and lie almost wholly within the Lower Sonoran life zone. The vegetation is sparse and consists mostly of desert scrub, notably creosote bush, yucca, and cacti. A few perennial grasses such as Indian ricegrass (Oryzopsis hymenoides), big galleta (Hilaria rigida), desert saltgrass (Distichlis stricta), desert stipa (Stipa speciosa), threeawns (Aristida spp.), and gramagrasses (Bouteloua spp.), as well as various annual grasses make up most of the cover. Winterfat (Eurotia lanata) and fourwing saltbush (Atriplex canescens) are frequently common and are valuable browse plants.

Acreage of Grazing Lands: The above discussion makes clear that California's grazing lands are greatly diversified. The acreage of these lands as compared to that of areas put chiefly to other uses is summarized as follows:

1. Grazing

Acres

A. Valley and foothill lands. . 22,000,000

B. Mountain ranges, largely on

national forests . . . . . . 15,000,000

Subtotal ......... $\overline{37,000,000}$

2. Timber, watershed, and recre-

ation (no grazing) . ......26,000,000

3. Cultivated, urban, and industrial $14,000,000$

4. Waste (desert, marsh, barren). .23,000,000

Total. ..........

It is evident that 63 per cent (item 1 plus item 2 above) of total California acreage is wild land suitable for range (grazing) and timber production, and has important watershed and recreation values. Approximately 37 per cent of total acreage, or a total of 37 million acres (A plus B above) are grazed annually. 


\section{THE NUTRITION OF RANGE GRASSES}

In planning a grazing program, the more experienced and successful stockman will arrange to utilize the forage when it is succulent, nutritious, and amply available for grazing. He will avoid putting the animals on a previously fully utilized range before the seedling grasses and other plants are well rooted, or before perennial tufts have produced a fair bite of new growth. Also he will avoid holding the animals overly long in the summer and fall on dry, sun-bleached range forage, unless they are given suitable supplemental feed to maintain body weight and condition $(15,54)$.

\section{ANNUAL VS. PERENNIAL NUTRITION}

The winter annual grasslands of valleys and foothills are frequently deficient for livestock grazing, especially from December to about March and from July to October. Unless one or more heavy rains occur in early autumn to favor abundant forage growth, the feed will be short despite heavy rainfall in December and January, when temperatures are generally too low to promote much leaf development (16). Often the volume of autumn and winter forage is so small as to require additional feed or hay concentrate, since in years of limited autumn rains the animals must subsist largely upon the dry forage of the previous season's growth.

Less complicated is the winter feed situation on ranges which support an abundance of perennial grasses, for they make measurably more growth in fall and early winter than do the annual species (53). Perennial stands are well rooted and ready to start leafing out from established clumps after the first good autumn rain, whereas the annual cover must go through the seed germination and seedling establishment stages before much leafage can be produced. Evidence supports the claim that before California's valley and foot- hill ranges were grazed extensively by domestic livestock, the plant population consisted to a large degree of palatable perennial grasses (9). Overgrazing, droughts, and introductions of Mediterranean plants (18)-some of which were good, others undesirable-gradually transformed these grasslands into a predominantly annual association (61).

Aside from its relatively slow forage growth, the annual grass cover also matures earlier, hence declines more rapidly in nutrition than a perennial grass stand. Chemical studies have revealed that the low nutrition of annual grasses, and of most other grass species, is directly correlated with the time of their maturity.

\section{NUTRITION AND PLANT GROWTH}

As long as new tissue is being formed, nutrition of the forage for livestock is generally satisfactory. The period of growth and food elaboration by grasses and other plants is long or short according to the inherent life span. Carbohy. drates (sucrose, glucose, and starch) -end products of photosynthesis-are formed in the chloroplasts of green leaves in the presence of solar radiation (light) from the combination of water and carbon dioxide. Photosynthesis can take place only when the tissues are active and succulent. The energy required by plants to carry out their life processes is obtained from the breakdown of the products of photosynthesis. Fatty substances as well as proteins are also formed in the cells, and are indirectly derived from the carbohydrates. The nitrate nitrogen, $\mathrm{NO}_{3}$, which enters into formation of proteins is absorbed by the roots and transported to the top growth. Soils rich in nitrogen and other essential nutrients tend to produce a luxurious grass stand which, under proper grazing use, is not likely to be replaced by other vegetation. On the contrary, impoverished soils, such as are characteristically found when the pro- 
tective plant mantle has been destroyed and the topsoil has eroded away, tend to support but a sparse stand of annual grasses and weedy plants which mature early and whose botanical composition fluctuates widely from year to year. Severe soil depletion may also be reflected in deficient inorganic compounds of phosphorus, calcium, potassium, and other elements essential to both plant and animal nutrition (13).

Study of the chemical composition of forage plants in their different stages of development and on different soil types has a direct practical application to the nutrition of range livestock. True, chemical analyses of pasture plants alone do not afford a complete measure of their nutritive value for animals; but they do indicate the approximate feeding value of pasturage when compared with digestion trials conducted with similar plants or feeds.

Correct appraisal of the livestock food value of range grasses and other forage plants presupposes knowledge of the seasonal pattern of their more important organic and mineral constituents. Indeed, such information is essential for efficient supplement-feeding, by which the ani-

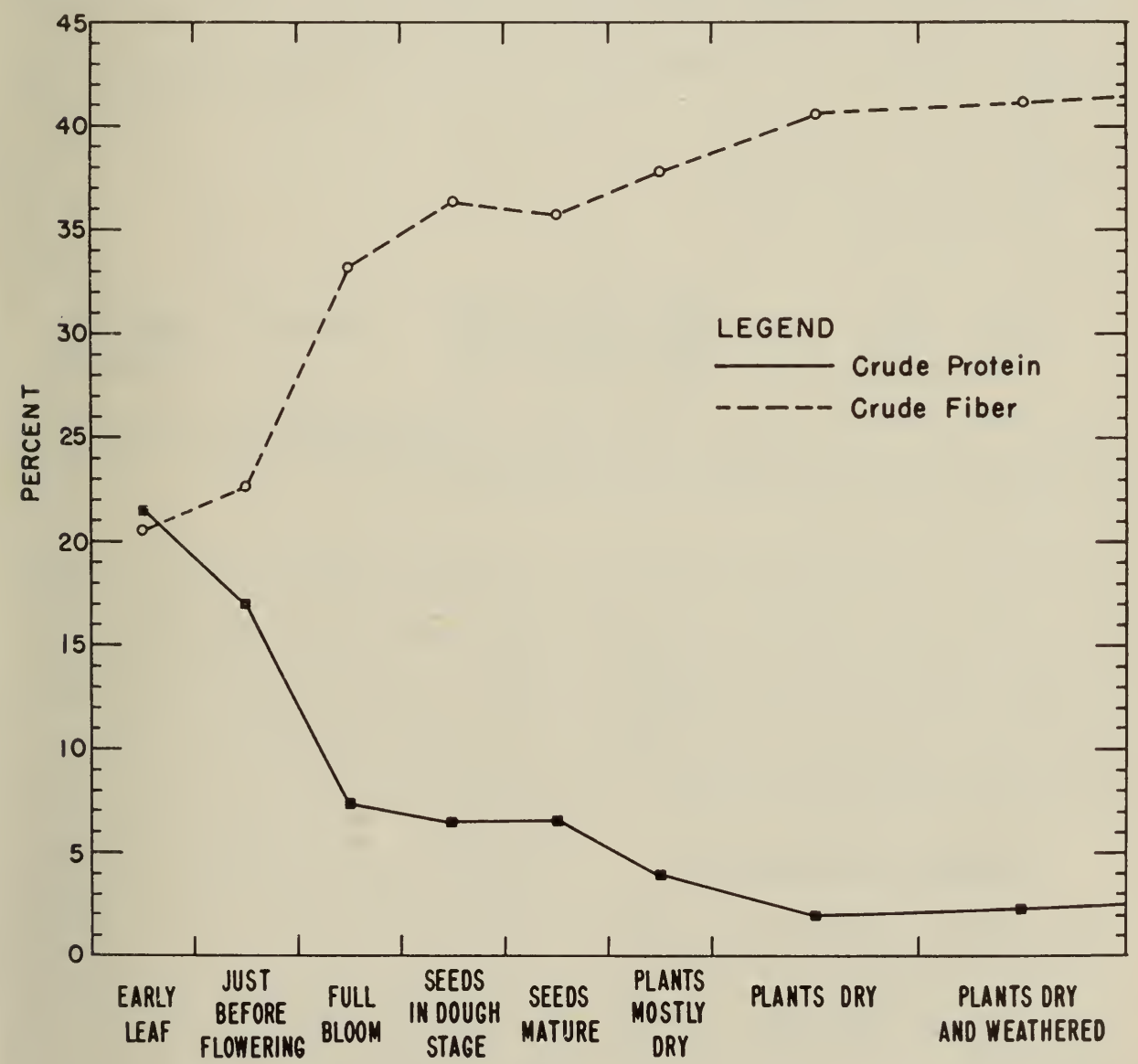

Fig. 6. March of crude protein and crude fiber in slender oatgrass (Avena barbata) ranging from the early leaf stage in the spring to dry and weathered growth in midsummer. The patterns of seasorial change here shown are typical of annual grasses. The protein content is inadequate for livestock after the seeds are mature and have been shed. 


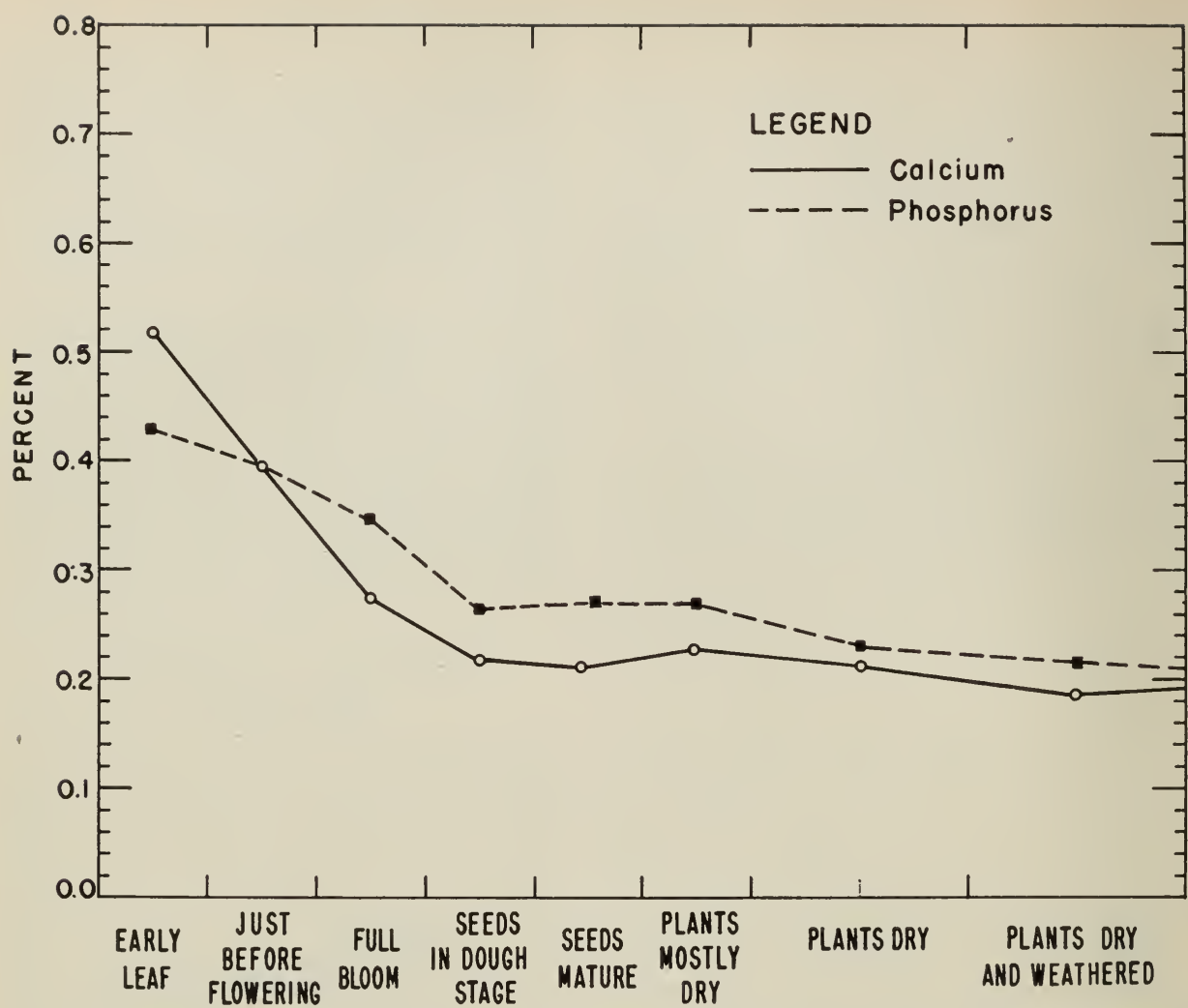

Fig. 7. Levels of calcium and phosphorus in slender oatgrass (Avena barbata) from the early leaf stage to a mature and weathered condition. Note the rapid decline in these constituents from early leaf stage to the time the seeds are in the dough stage

mals may at all times receive an adequate diet. Guilbert and associates (15) have shown that greatest efficiency in cattle production is obtained from a high plane of nutrition which will assure continuous growth and development; and Miller (38) has emphasized essentially this same point in range sheep raising.

\section{NUTRIENT DEFICIENCIES}

The organic constituents most likely to be deficient on California ranges, other than total digestible nutrients, are vita$\min \mathrm{A}$ and protein. The most common inorganic deficiency is phosphorus (16, 39).

Vitamin A deficiency: The vitamin A content of grasses and other plants is lost rapidly when they reach maturity, or when the leafage is leached by rains or bleached in the sun. Animals held for many weeks on predominantly dry feed will show various symptoms of this deficiency. According to Hart and Guilbert (17) some of the symptoms in cattle are: night blindness, which is associated with eye lesions; birth of weak or dead calves, a condition which simulates infectious abortion; and severe diarrhea of weakborn calves. The body, however, usually accumulates a reserve supply of vitamin A during the growing season, which, with the eating of vestiges of green feed, is usually adequate to protect the animal's health during a prolonged dry season on most ranges. Where almost no palatable green feed is available, green, properly cured hay will correct the deficiency. 
Protein deficiency: Changes in the levels of other organic constituents of grasses with advancement in the growing season are also conspicuous. Thus, the crude protein percentage of grass leafage decreases gradually from earliest appearance of leaf blades to plant maturity. (Fig. 6.) Highest percentage of crude protein and lowest percentage of crude fiber occur in the early leaf stage of highly succulent herbage. The percentage of crude protein declines most sharply from early leaf to full bloom, and more gradually thereafter, reaching lowest levels when the plants are dry and weathered, a stage reached among an- nual grasses in early summer in the foothills. At that time the crude protein percentage may decline to 5 per cent or less, levels which are inadequate for animal nutrition.

As the levels of crude protein decline, the percentage of crude fiber (and indigestible lignin) increase in nearly inverse proportion. This results in a decrease in palatability and digestibility of the herbage, which is at its lowest when the plants are fully mature and the seeds are cast $(13,58)$. On foothill and valley grassland of annual growth this stage is reached during April and May, depending on the locality, and somewhat later

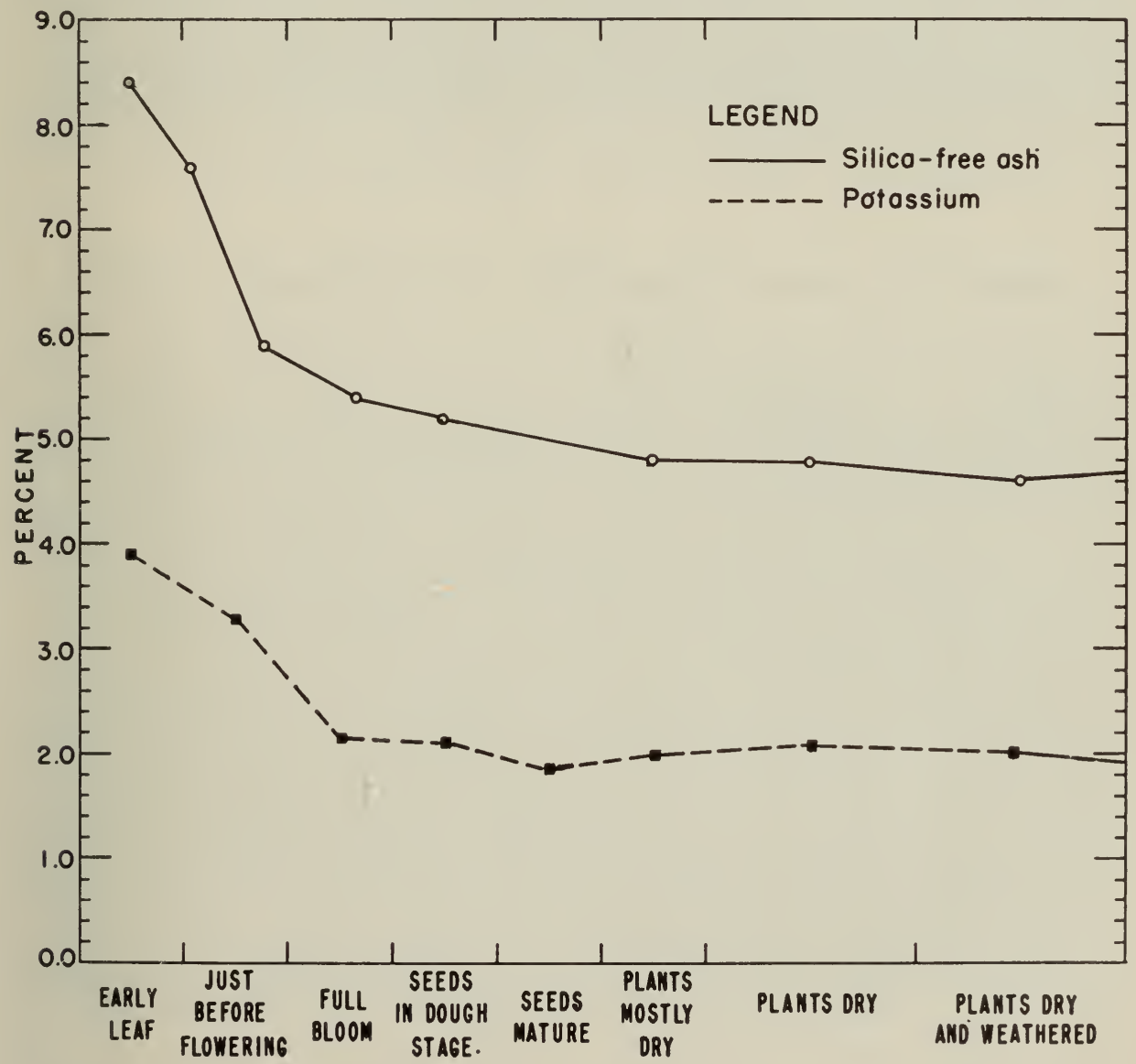

Fig. 8. Changes in silica-free ash and potassium in slender oatgrass (Avena barbata) from early growth to full maturity. Note the rapid decline in these constituents from the early leaf stage to the time of full bloom. 
in the perennial grass stands of these regions.

Inorganic constituent deficiencies: Patterns similar to that of crude protein also occur in the percentages of such inorganic constituents as silica-free ash, calcium, phosphorus, and potassium. (Figs. 7, 8.) Levels of these constituents are highest in the young leaf stage of grasses and lowest in the mature, bleached stage. Phosphorus is most likely to be deficient in livestock nutrition on California foothill and valley ranges of mixed annual forage stands, although where an ample supply of palatable grasses abounds, phosphorus inadequacy probably seldom occurs. This is because, first, the minimum percentage of around 0.10 per cent phosphorus-regarded as the danger signal by Ingel (28) and others-is probably seldom reached in California grasslands; further, whereas in other weeds and shrubs calcium pre- ponderates over phosphorus at plant maturity, a condition unfavorable to best assimilation of phosphorus by livestock, the ratio of calcium to phosphorus in the grasses studied is not far from a favorable $1: 1$ in any growth stage.

Any management plan favoring increase of the more desirable perennial grasses on the annual ranges will help to tide over the dry summer period of low nutrition. Establishment of meadows or irrigated pasture of perennial grasses and legumes, where the animals may feed during the critical period on the natural range, is also highly recommended. Moreover, supplemental feeding of concentrates to supply the deficiency of protein and minerals in range forage is usually sound economics.

Further information about the nutritional value of the various California range grasses will be found in the descriptive section, beginning p. 31 .

\section{CONDITION AND UTILIZATION OF GRASSLAND RANGES}

Sustained production from grasslands is possible only if the important palatable grasses are kept in vigorous condition. Essential to the maintenance of such condition is the application of standards by which the effects of past and present grazing practices may be accurately evaluated. Two such standards are range condition and range utilization. The first, range condition, classifies range areas by comparing present yield of forage to maximum yield under conservative or proper grazing. The second, range utilization, classifies by comparing present intensity of grazing to ideal intensity under proper range management.

Care must be taken to distinguish between range condition and range utilization. The first evaluates the productivity of the range; the second, on the basis of this evaluation, sets up the degree of utilization that will best maintain range condition-that is, it sets up practical guides by which stockmen may judge how close the grazing may be without injuring the important forage plants. The poor condition of many grassland ranges is the result of past overutilization or repeated close grazing. Ranges in good condition are usually the result of continued proper grazing use.

\section{RANGE CONDITION CLASSIFICATION}

Range condition compares the present production capacity of an area to a desirable standard-as, for example, a similar area grazed on a sustained-yield basis. Range condition, then, is the product of long-time grazing management, and its evaluation serves as a basis for management planning.

Condition and plant succession: Judging range condition is essentially a means of interpreting range history. Studies on subalpine ranges, for example, have revealed that vegetation and soil develop interdependently. Several well 


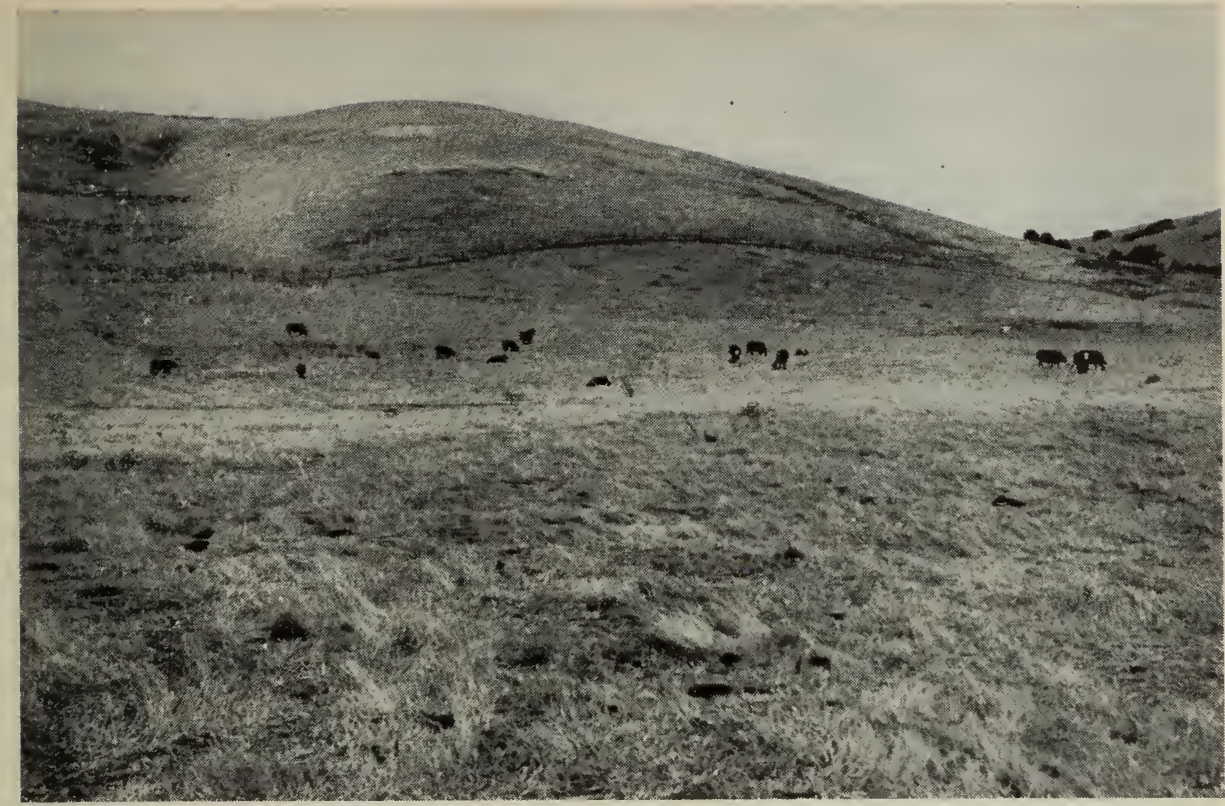

Fig. 9. An annual range in excellent condition. Note the absence of undesirable plants and the abundance of ungrazed forage residue. Photo taken Sept. 10, 1948.

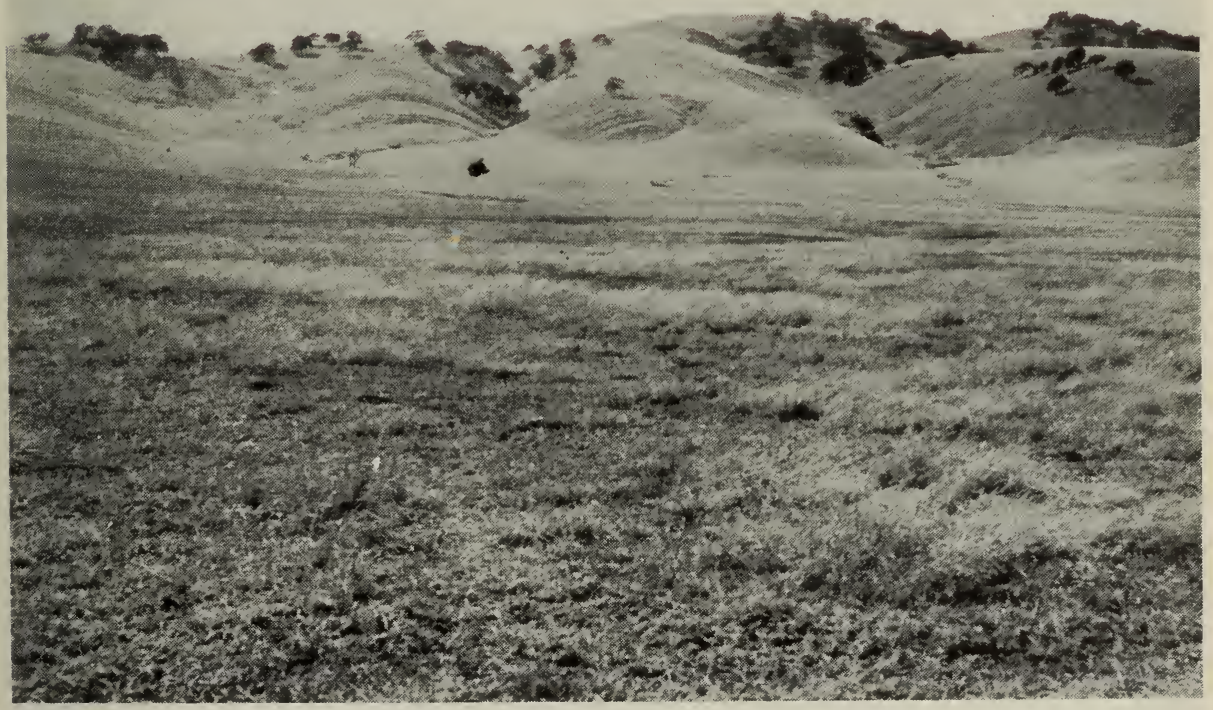

Fig. 10. An annual range in good condition. Although this range is producing less forage than the one shown in fig. 9 , it has a protective covering of desirable forage plants. Photo taken Sept. $10,1948$. 


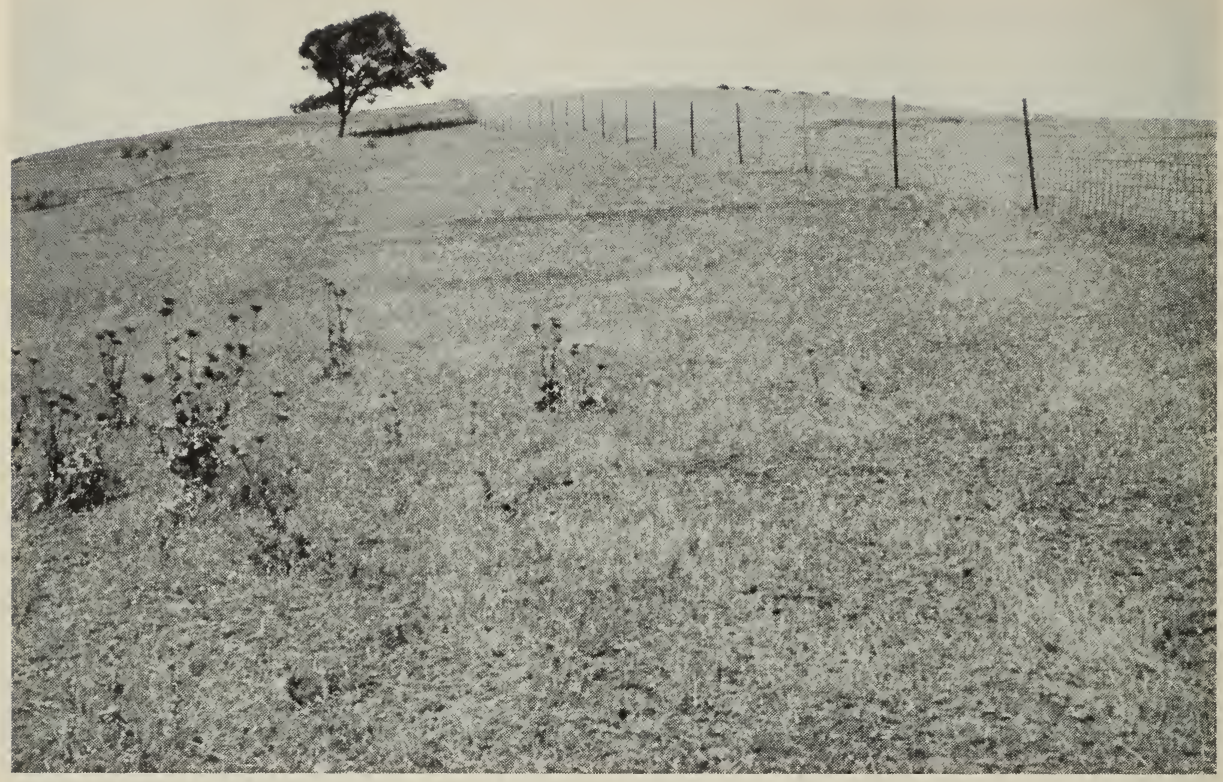

Fig. 11. An annual range in fair condition. This range is producing much less forage than it could under improved grazing management. Note the lack of forage residue and the undesirable plants in the foreground. Photo taken Sept. 10, 1948.

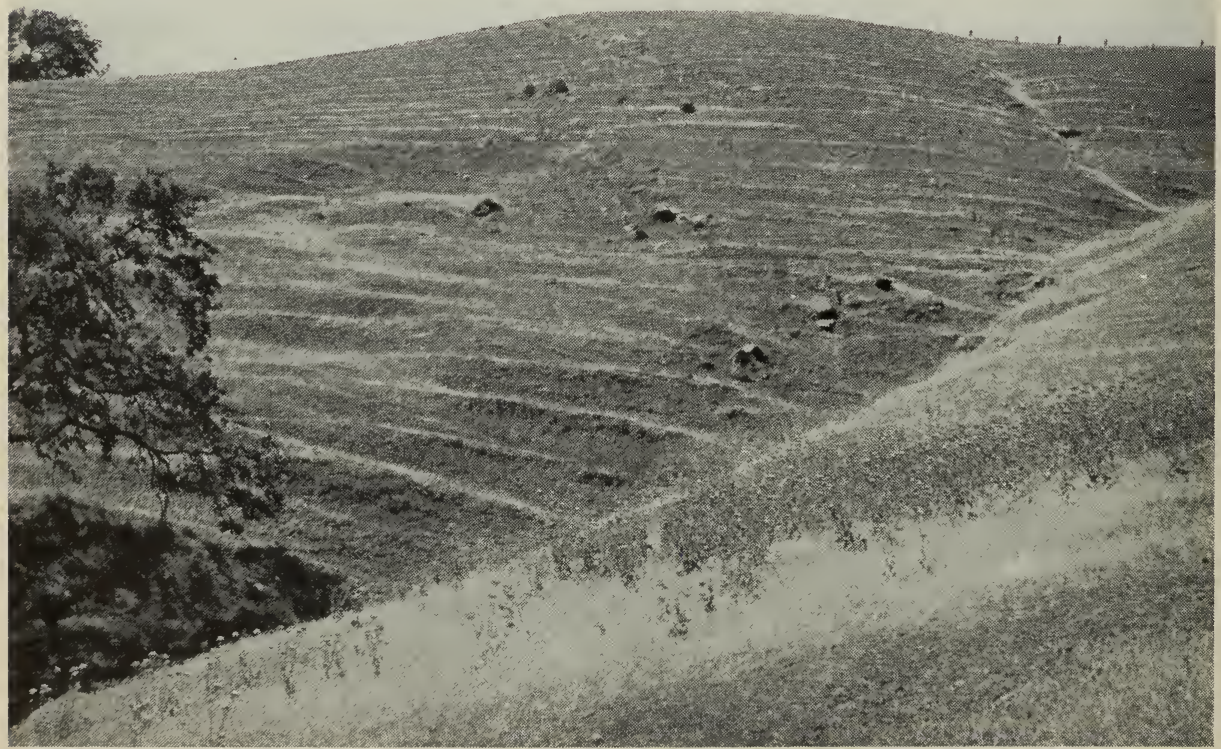

Fig. 12. An annual range in poor condition. Continued heavy grazing has greatly reduced forage production on this range. Note the abundance of undesirable plants and the almost complete lack of forage residue to protect the soil from trampling. Photo taken Sept. 10, 1948. 
defined forms of vegetation succeed each other coincidentally with soil changes (49). Most investigators have made use of this relationship between range condition and successional stages of the plant cover in rating perennial grasslands. Thus on subalpine ranges in eastern Oregon and eastern Washington, a heavy stand of green fescue (Festuca viridula) has been found to indicate ranges in good condition, whereas large quantities of subalpine needlegrass (Stipa columbiana) indicate ranges in poor condition (42). Condition of mountain meadows in the same area (44) is determined by the abundance of tufted hairgrass (Deschampsia caespitosa). This grass is abundant in meadows in good condition where it furnishes about 80 per cent of the forage; on meadows in fair condition it comprises only a fourth of the volume.

Trend: A phase of range condition not to be overlooked is trend, that is, whether the range is improving or declining. The most important indicator of trend is the scale of plant succession. Knowledge of plant succession is therefore necessary in order to make proper seasonal or yearly adjustments in the degree or season of grazing. Improving perennial ranges generally display an increase in density and vigor of palatable plants; deteriorating ranges show a corresponding decrease $(40,60)$. On California annual ranges, trend may be indicated by change in relative abundance of the more palatable grasses and forbs.

Other plant and soil indicators of trend are the amount and rate of nulch accumulation, and erosion conditions. Here it is important to distinguish between what has happened and what is happening. For example, if no new gullies are being formed, or if profiles of existing gullies are less sharp-angled and the plant cover is vigorous, the trend is likely to be stable or upward. On the other hand if new gullies are being formed, or if profiles of the older ones are sharp-angled and the plant cover is thinning, the trend is probably downward.

Evaluation: In evaluating range condition it is important to classify site productivity within broad ecological associations (27). In this way the stockman avoids judging differing areas without a true basis of comparison. Differences in yield may in some cases be more directly due to slope or expossure than to condition of the range. And on some annual ranges of California, plant composition and yield may be influenced more by soil type. The cover found on a sandy soil, for example, should not be compared directly with that occupying clay or adobe soils.

Production standards: Since range condition classification is essentially a rating of forage production, a definite relationship exists between class and production. Most range condition classifications involve the following ratings:

Condition

Production (per cent of potential forage capacity)

Excellent . . . . . . . . . 75-100\% (fig. 9)

Good ................50- 75\% (fig. 10)

Fair ...............25-50\% (fig. 11)

Poor-very poor ...... less than $25 \%$ (fig. 12)

Condition classifications for California annual ranges in various areas of the state have been prepared by the Soil Conservation Service. Here, however, primary emphasis has been placed on species composition of the forage cover (14). Other factors also used in the ratings are forage density, plant vigor, erosion, and mulch (46).

\section{RANGE UTILIZATION STANDARDS}

Proper range utilization is based on the degree of use of certain so-called key species, that is, a few important kinds of forage plants which must be maintained or increased to insure satisfactory range condition, or production of forage at a satisfactory level. 
Annuals: On the annual ranges, utilization standards are based on the amount of the current year's forage crop that should remain on the ground at the time the next year's crop starts growth (25). The examiner can best judge utilization of the annual cover by making use of photographs showing different grazing intensities. Degree of utilization is then determined by comparing the vegetation remaining on the ground with photographs showing desirable amounts of plant residue. If the check on utilization is made earlier than at the time growth starts in the fall, loss of forage through weathering and/or grazing must be estimated and appropriate allowance made for any loss. Not less than 300 to 600 pounds of forage per acre should remain unutilized at the end of the grazing sea- son to maintain or improve range condition (65). Such use is generally referred to as moderate grazing, and is recommended as the best management for annual ranges throughout the state (24).

Perennials: Various techniques are employed to determine utilization on perennial grassland ranges. These may involve description of the cover or actual measurement (41). Since the relation of height to weight of grasses has been studied segment by segment for the entire length of selected perennial species, more exact quantitative methods have been devised for measuring utilization on perennial grasslands than on the annual cover $(34,64)$. Use of stubble height measurements of certain key species as indicators of volume removed has proved popular, practical, and generally reliable (5).

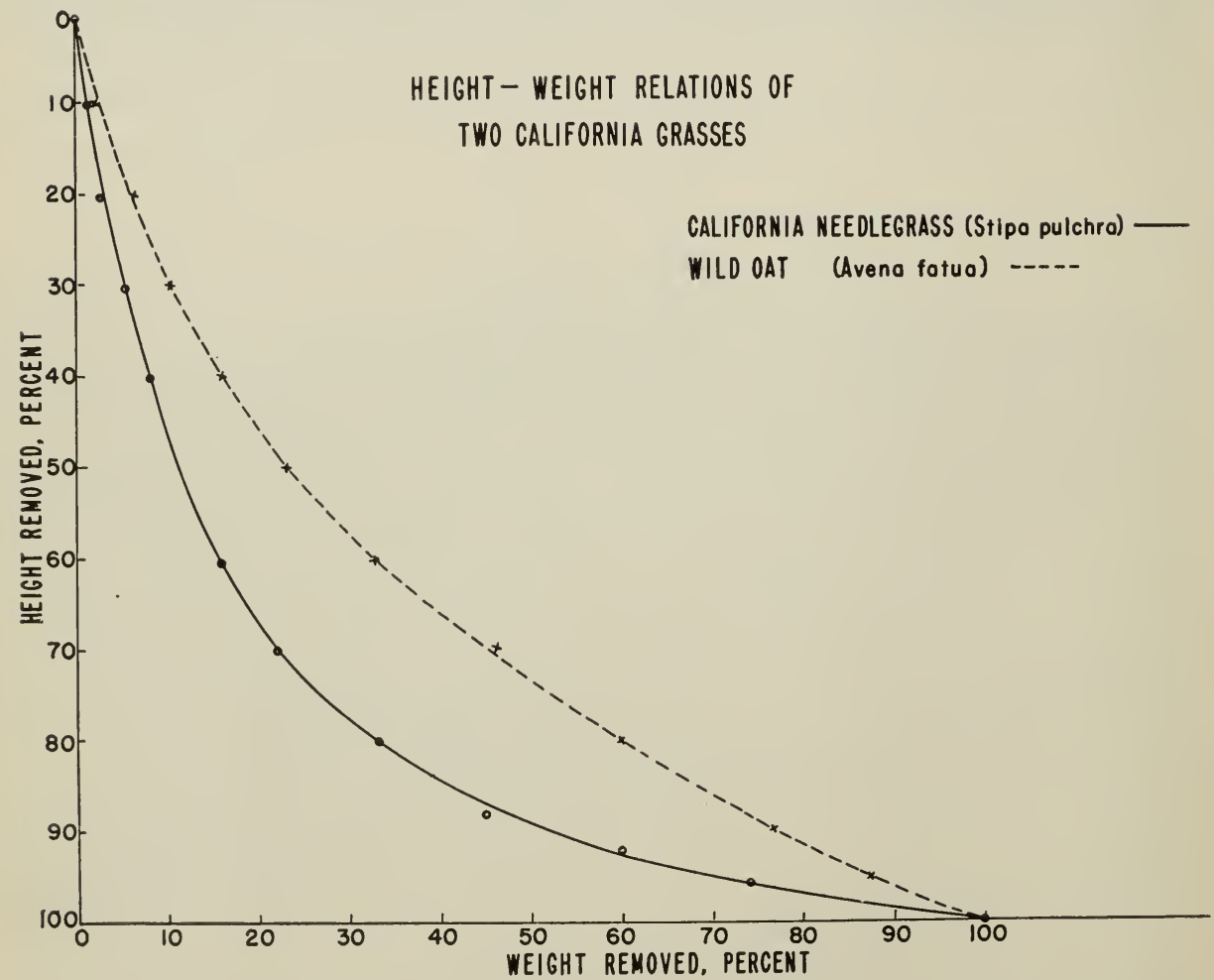

Fig. 13. Graph showing distribution of weight (volume) of forage in relation to height of two representative grass species found on California ranges. The greater amount of basal leafage typical of perennials, here represented by California needlegrass (Stipa pulchra), is shown by comparing the height-weight curve of needlegrass with the more nearly linear curve of wild oat (Avena fatua), an annual. 
The degree of comparative utilization is derived by sampling the volume of grazed versus ungrazed plants. Differences in height of grazed and of ungrazed plants, expressed in percentage, are then converted into percentage vol- ume (weight) removed by consulting a utilization chart, or specially prepared "slide rule." The charts or rules are so constructed as to depict height-weight relations for any height of any of the different key species. (Fig. 13.)

\section{ARTIFICIAL RANGE RESEEDING}

Demands of an increased human population and a rising per capita consumption of meat in California have awakened livestock men to the need of improving feed supplies from the native ranges. The value of good livestock and forage management in getting the best use from grasslands has already been pointed out. Artificial reseeding of suitable range areas is another means of increasing the forage output. Little is known at present of the economics of reseeding wild lands, but successful revegetation by this means apparently is restricted to sites of high productivity. Even on good sites few studies have been conducted long enough under actual grazing conditions to deter. mine the practicability of such reseeding; and few of the failures have been appraised as one of the risks inherent in attempting to reseed different range sites. Conservative grazing and proper season of use are important follow-ups after reseeding if success is to be obtained (4); otherwise the reseeding effort is almost certain to fail.

\section{CHARACTERISTICS OF GRASSES}

Grazing lands produce plants other than the true grasses, but the most important plants on the range are the grasses. They are not necessarily more palatable and nutritious than some of the better forbs or browse (broad-leaved plants) like bur clover or bitterbrush, but all factors considered they rank first as livestock forage. The perennial grasses fluctuate relatively little in forage production from one year to another; they are wholesome, never causing bloat, and are nutritious and palatable; and since the leafage cures well on the ground it provides valuable food for livestock at all seasons. Grasses in addition endure closer and more frequent grazing than most other plants. Growth of the grass leaf is localized at the base of its two constituent parts, the sheath and the blade, instead of taking place throughout

${ }^{3}$ References extensively consulted in preparation of this section are: Abrams (1), Chase (6), Hitchcock $(19,20,21)$, Jepson (30), and Sampson and Chase (52). the leaf area as in forbs. When the leaf of a forb is grazed off no new growth can take place except by new shoots, but when a grass blade or stem is cropped back, growth continues at the base until either or both of the grazed members have been replaced.

Grasses are herbs with fibrous roots and jointed stems (culms), hollow (rarely pithy), except at the nodes, which are solid. (Fig. 14.) The culms may be simple (not branching), though there is a potential branch at every node, and, if the main culm is cut off as in grazing, one of the latent branches will develop. Or the culms may bear branches at one or all the nodes. The branching habit is fairly uniform for any given species, and mostly so for a whole genus.

\section{VEGETATIVE PART}

The root, stem, and leaves form the vegetative part of the grass and are all that are concerned with the life of the individual plant. The flowers have to do 

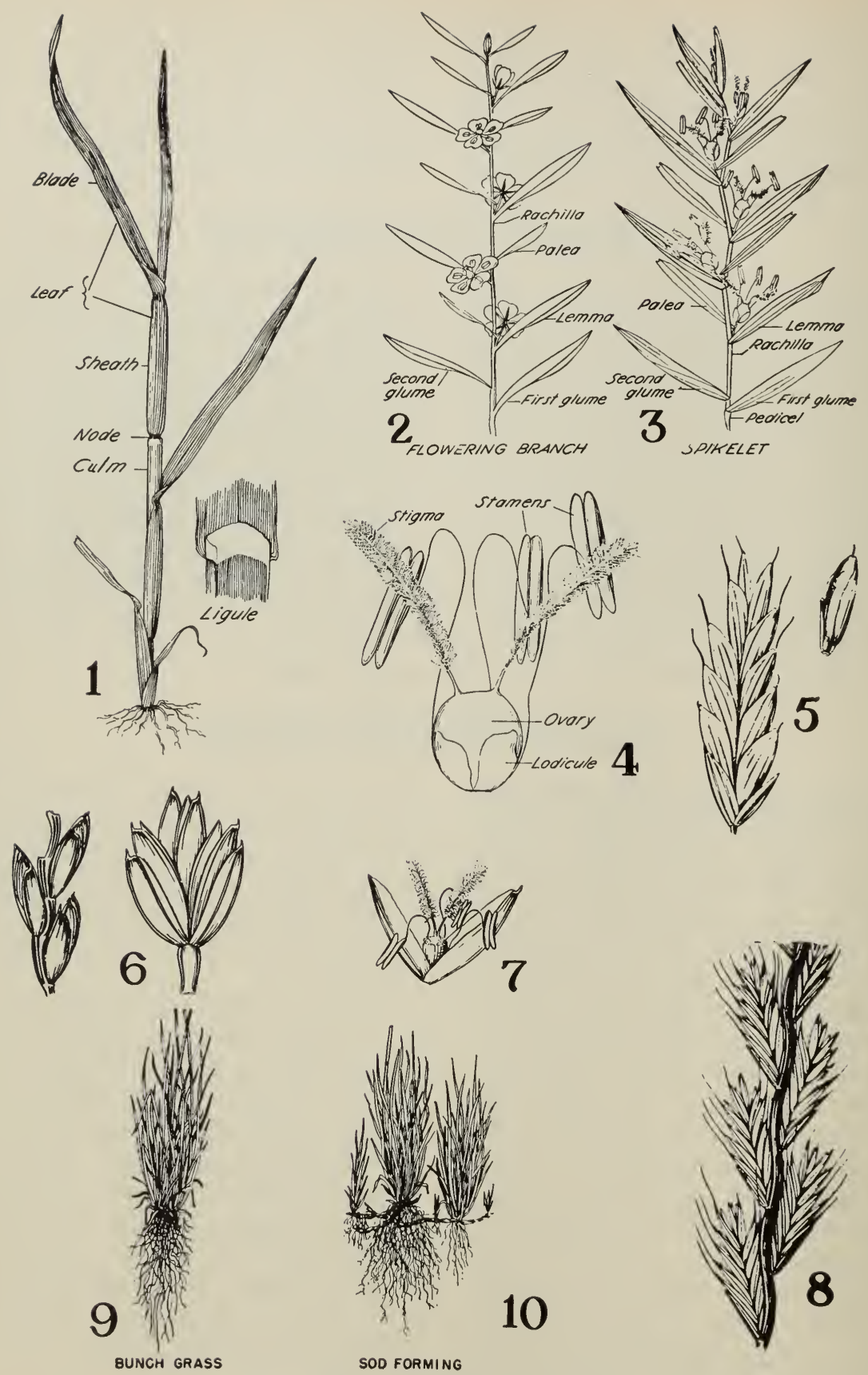

Fig. 14. Vegetal and floral characteristics of grasses. (1) Simple culm with roots, leaves, and ligule. $(2,3)$ Comparative diagrams of a flowering branch and a grass spikelet. (4) Details of a typical grass flower. (5) Spikelet and floret. (6) Three joints of a spike of wheat and a single wheat spikelet shown laterally. (7) A floret of wheat. (8) Part of a spike of Italian ryegrass (Lolium multiflorum). $(9,10)$ Comparative diagrams of a bunchgrass and a sod-forming grass. 
with perpetuating the species. In grasses the vegetative parts are more uniform and characteristic than in most other families. Stem and leaves alone of any plant will tell whether or not it is a grass.

The leaves are borne one at each node, always in two ranks. They are parallelveined and composed of two parts, the sheath, which surrounds the culm like a split tube, and the blade, which is usually strap-shaped. At the junction of sheath and blade, on the inside, is a small appendage-the ligule-consisting of a thin membrane or a ring of hairs. Sedges, some of which are commonly called sloughgrasses, resemble grasses, but their stems are solid and their leaves are in three ranks. Some rushes resemble grasses but their stems are not jointed; their flowers are in form like very minute lilies, borne in large or small heads, not in two ranks in spikelets, as in grasses.

\section{LENGTH OF LIFE AND VEGETATIVE REPRODUCTION}

Grasses may be annuals-germinating, seeding, and dying in a single season, like the annual bromegrasses-or perennials, the individual plants living from two to several years and seeding year after year. Perennial grasses, besides producing seed, increase vegetatively. Shoots are formed at the basal nodes and live over the winter. If these shoots grow up inside the sheaths of the parent stems, a bunch grass, such as fescue, is formed. If the shoots push through the sheath and run along the surface of the soil, a mat is formed as in Bermudagrass. If the shoots run underground a tough sod is formed, as in Kentucky bluegrass and the sod-forming wheatgrasses. These modified stems (rhizomes or rootstocks) are jointed and bear scales (which are reduced leaves). Roots develop from the lower side of the nodes and leafy shoots from the upper. These underground shoots develop into new plants which send out new rhizomes. Thus a dense network is formed below ground, new plants developing continually and replacing the old ones that die, and forming a permanent sod. For this reason grasses of this type withstand grazing and trampling better than bunch grasses. In bunch grasses the tuft enlarges year by year as new shoots are produced from the lower nodes of each culm, two or more being sent forth each year. The dense tufts of foliage of pine bluegrass and Idaho fescue and similar grasses are composed of the young leafy shoots that are to bear the seed stalks the following year. In very densely tufted grasses, however, only a few of these shoots actually flower.

\section{FLOWERS AND SEED}

The flowers of grasses are small and inconspicuous, being reduced to the essential organs-a single ovary with two styles (one in corn) bearing feathery stigmas, and three stamens (rarely one or six). The ovary contains an ovule which when fertilized develops into the seed; the stamen consists of a two-celled anther borne on a long filament. The cells of the anther contain innumerable pollen grains. At flowering time the cells split and the minute pollen grains are scattered by the wind. Those that fall on the sticky stigmas of flowers of the same kind of grass germinate and form a minute tube which pushes down through the style and carries their contents to the ovule, fertilizing it. Each of these tiny flowers is borne in the axil of a small green bract (the lemma) and is enveloped in a smaller inner bract (the palea). The flower with its lemma and palea is termed the floret. The hull on a grain of barley, wheat or oats, and the hard shell-like covering of a grain of millet, consist of lemma and palea. The florets, like the leaves, are borne in two ranks upon a little axis or rachis (the rachilla). Below the florets are two bracts without flowers (the glumes). The glumes, rachilla, and floret together are called the spikelet. The spikelet is a miniature leafy branchlet, with sessile (stemless) flowers in the axil 
of all but the lowest pair of leaves, the glumes and lemmas being altered or specialized leaves. The jointed rachilla corresponds to the jointed culm and, like it, usually breaks at the nodes, the internode (the part between the nodes) remaining attached to the floret at its base; just as in a broken grass stem the internode of the culm remains with the sheath that surrounds it, that is, the break normally comes just under the node.

Glumes and lemmas, axis and rachis are all subject to specializations and modifications. The classification of grasses is largely based upon the combination of these modifications.
In oatgrasses, bromegrasses, fescues and bluegrasses the spikelets are on pedicels (little stems) on the branches of a panicle. In some grasses, timothy and the millets, for example, the panicle branches and pedicels are so short that the head looks like a spike. In wheat, barley, rye, and their wild relatives, the wheatgrasses, wild barleys, and wild-ryes, the spikelets are sessile (without a stem) on opposite sides of a simple rachis, forming a spike. In gramagrasses the spikelets are sessile, but close together on one side of a rachis, forming onesided spikes which are borne few to several on a simple main axis. 


\section{IMPORTANT RANGE FORAGE GRASSES}

The grass family is so large, consisting of some 600 genera, that for convenience it has been divided into different tribes, 14 of which are found in the United States, and nine in California. The classification is based on the structure of the spikelets and their arrangement in the inflorescence. The following outline gives a general description of the nine California tribes. The key to tribes (p. 32) classifies them botanically. Compare key with the illustrations below.

1. The Fescue Tribe (Festuceae) contains the greatest number of genera, widely distributed, but most abundant in the temperate and circumpolar regions of the northern hemisphere. Poa, Festuca, and Bromus, especially, contain a large number of species of excellent forage grasses.

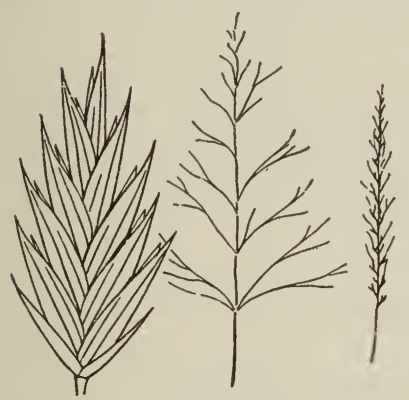

1. Festuceae

2. The grasses of the Barley Tribe (Hordeae) mostly occupy temperate and cold-temperate areas. To this small tribe belong the important cereals, wheat, bar-

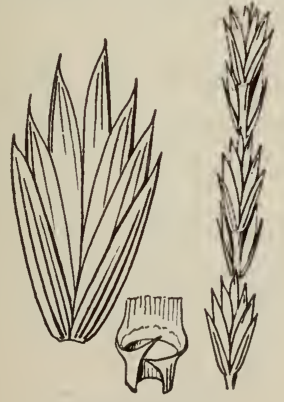

2. Hordeae ley, and rye, cultivated from prehistoric times, and also valuable hay and range grasses. A few of its members are injurious at maturity to grazing stock because of the barbed awns which work into the mouth, nostrils, and eyes.

3. The Oat Tribe (Aveneae) is relatively small, its genera mostly in OldWorld warm, temperate, and tropical regions, only about ten genera being native to the Americas.

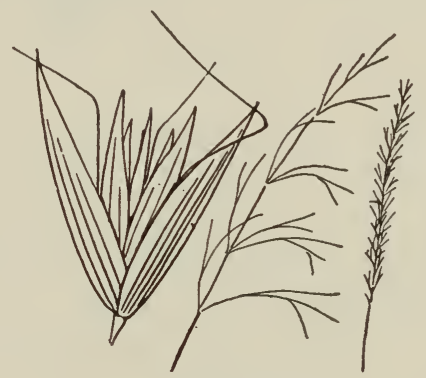

3. Aveneae

4. The genera of the large Timothy Tribe (Agrostideae) are widely distributed. Agrostis, Calamagrostis, and Stipa, especially, occupy the temperate and northern prairies, plains, and steppes of America and Eurasia, and are abundant again in temperate and cold-temperate regions of the southern hemisphere. Species of Aristida (threeawns) are characteristic of arid and semiarid tropics and warm temperate regions of both hemispheres, especially abundant in South Africa.

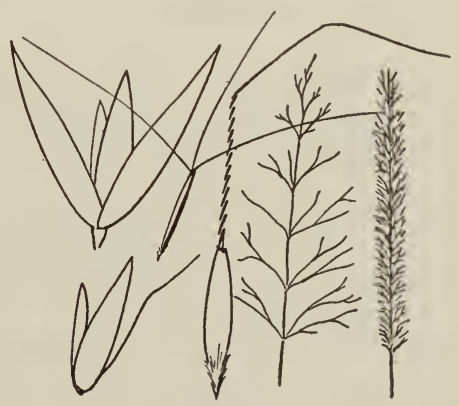

4. Agrostideae 
5. The small Curly Mesquite Tribe (Zoysieae) belongs mostly in the OldWorld tropics and the southern hemisphere, only four genera, two of them introduced, being found in the United States.

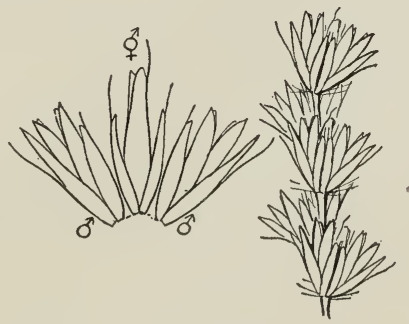

5. Zoysieae

6. The genera of the Grama Tribe (Chlorideae) mostly occupy warm temperate regions and tropics, but Beckmannia, rather artificially placed in this tribe, is a circumpolar genus. Spartina, belonging to this tribe, is the important land builder of our interior fresh water marshes and also on mudflats and estuaries along the seacoast. The region about Reclamation on San Pablo Bay was built up by Spartina foliosa.

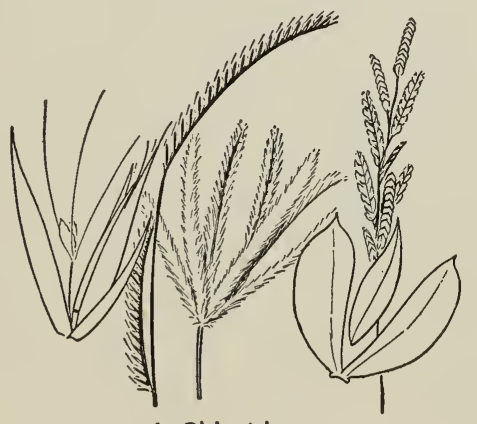

6. Chlorideae

7. The Canarygrass Tribe (Phalarideae) consists of only six genera, two native to the United States and two introduced. Phalaris is the largest and only important genus, $P$. arundinacea L., reed canarygrass, being a constituent of lowland hay and also a land builder in converting freshwater marshes to prairie.

8. The genera of the large Millet Tribe (Paniceae) are abundant in the warm

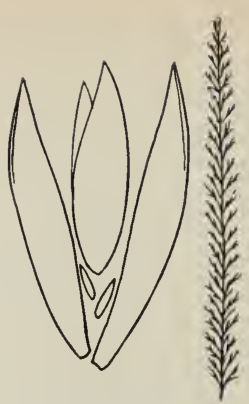

7. Phalarideae

temperate and tropical regions of both hemispheres. The tribe contains relatively few economic species. The cultivated Setarias (millets) are important food plants in parts of the Old World. Botanically the tribe is extremely interesting, with many highly specialized and curious forms.

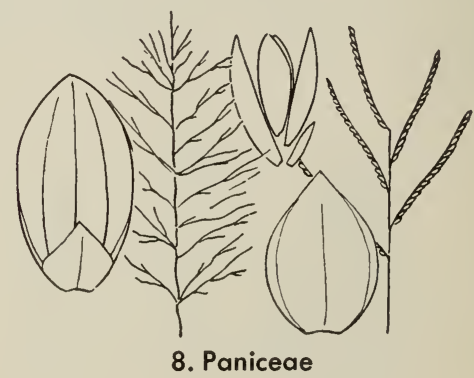

9. The Sorghum Tribe (Andropogoneae) likewise contains a large number of highly specialized genera. Sugarcane is the most important species. Sorghum is a food plant in parts of Africa and Asia, and is widely cultivated also for forage. The genera principally occupy the tropics and warm temperate regions of both hemispheres.

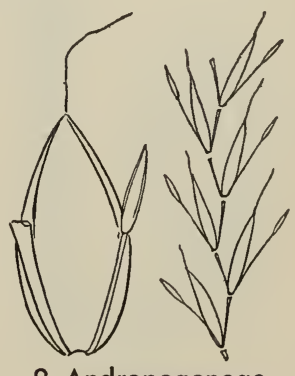

9. Andropogoneae 


\section{KEY TO TRIBES}

How to use the key: Consult the outermost series of paragraphs, and choose the one with which the grass in hand agrees. (Certain genera and species might reasonably be referred to more than one paragraph, and may be looked for under both paragraphs until closer distinctions are found.) Follow the key until it leads to a tribal name (in large type). Turn then to the page indicated in the parentheses after each tribal name, and there consult the further keys which break down the tribe into genera and species.
Note: The key gives tribal names in order of botanical classification. The text, however, discusses the tribes in order of forage which each contributes. Hence the numbers which precede the tribal names in the key and refer to the order of discussion in the text are not necessarily consecutive. The method of numbering by importance is also followed in the keys to the genera of tribes and to the species of genera. Remember that for localized areas this order of importance may be different than for the whole state.

Spikelets on pedicels in open or contracted panicles, or in racemes

Spikelets with 2-many florets

Glumes shorter than the lowest florets (see also Koeleria in Aveneae)

1. FESTUCEAE (p. 34)

Glumes or one of them as long, mostly longer than the lowest florets

3. AVENEAE (p. 74)

Spikelets with 1 perfect floret

Spikelets all alike (except in Phalaris paradoxa)

Spikelets without sterile florets below the perfect terminal one

4. AGROSTIDEAE (p. 82)

Spikelets with a sterile (sometimes staminate) floret below the perfect terminal one

Spikelets laterally compressed; sterile florets reduced to small scales adhering (in our genus) to the perfect floret

7. PHALARIDEAE (p. 109)

Spikelets dorsally compressed; falling entire

8. PANICEAE (p. 111 )

Spikelets of 2 kinds, staminate or neuter, and pistillate in the same inflorescence 9. ANDROPOGONEAE (p. 114)

Spikelets sessile on the rachis forming spikes, or in groups of 3, the group falling entire Spikelets in $3 \mathrm{~s}$ falling entire, the rachis continuous

5. ZOYSIEAE (p. 105)

Spikelets not in $3 \mathrm{~s}$ falling entire from a continuous rachis (in $3 \mathrm{~s}$ falling attached to a joint of the disarticulating rachis in Hordeum)

Spikelets on opposite sides of the rachis, the spike solitary

2. HORDEAE (p. 62)

Spikelets on one side of the rachis, forming 1-many small 1-sided spikes, these borne on a common axis

6. CHLORIDEAE (p. 105) 


\section{FESCUE-BLUEGRASS-BROMEGRASS TRIBE (FESTUCEAE)}

This tribe, embracing the all-important fescues, bluegrasses, and bromegrasses, includes the best range plants in the state.

The outstanding characters of the tribe are: Spikelets few- to several-flowered, pediceled in open or narrow panicles; florets falling from the glumes at maturity; culms mostly simple.

\section{KEY TO GENERA}

Spikelets of 2 kinds, the staminate and pistillate on separate plants; culms erect from creeping rhizomes, with numerous conspicuously 2 -ranked leaves

4. Distichlis (p. 53)

Spikelets all alike, the florets perfect

Spikelets strongly compressed, crowded in 1-sided clusters at the ends of stiff naked panicle branches; glumes and lemmas conspicuously ciliate on the keel

7. Dactylis (p. 60)

Spikelets not strongly compressed, if somewhat compressed glumes and lemmas not ciliate on the keel

Glumes papery; lemmas firm, strongly nerved; upper florets sterile, mostly reduced to a clubshaped rudiment infolded by the broad upper lemmas

5. Melica (p. 54)

Glumes not papery; upper florets like the rest, but reduced

Lemmas 3-nerved; rachilla continuous, paleas persistent after fall of lemmas

8. Eragrostis (p. 61)

Lemmas 5-9 nerved (intermediate nerves sometimes obscure in Poa); rachilla disarticulating Spikelets 15-30 mm long; grain flattish, adhering to the palea 1. Bromus (p. 34) Spikelets less than $15 \mathrm{~mm}$ long (sometimes $12-15 \mathrm{~mm}$ in Festuca californica); grain not adhering to the palea

Leaf blades boat-shaped at tip; lemmas awnless, often cottony at base or on the keel; spikelets small

3. Poa (p. 47)

Leaf blades pointed, not boatshaped; lemmas never cottony

Lemmas obtuse, the nerves parallel, not converging at the summit

Nerves prominent; tall plants of woods or fresh-water marshes 6. Glyceria (p. 59)

Nerves faint; lower plants of alkali soil

9. Puccinellia (p. 62)

Lemmas awned or pointed, the nerves converging at the summit 2. Festuca (p. 42)

\section{BROMEGRASSES (BROMUS)}

Bromegrasses are mostly rather tall, relatively coarse, perennials or annuals, growing in clumps; blades relatively soft and wide; spikelets larger than those of any other genus in California; lemmas mostly awned; seed large, thin, chaffy.

Of the 30 bromegrasses in the state, 16 are perennials and 14 annuals. Some 12 species of the group are important contributors to the annual range forage crop.

Perennials: The perennial bromes have a wider elevational range than the annuals, and are most abundant in the ponderosa-pine type or Transition zone. (Fig. 15.) They thrive on rich, deep, moderately moist soil, but will also grow on rather poor, depleted soils and fairly dry sites. As a consequence of the adapta- tion of many species to poor growing conditions, the perennial bromes make their appearance comparatively early in the establishment of a perennial plant cover, usually preceding the bluegrasses, fescues, and needlegrasses (52). These species rate among the best forage grasses on the western ranges. The large leafy plants yield an abundance of forage which is relished by all classes of stock during the growing season. Except for smooth brome, these grasses depend exclusively upon seed to reproduce. Under proper management and normal growth conditions an abundance of seed is produced and the range is adequately reseeded. The most abundant and important perennials are: California brome, smooth brome, narrow-flowered brome, woodland 


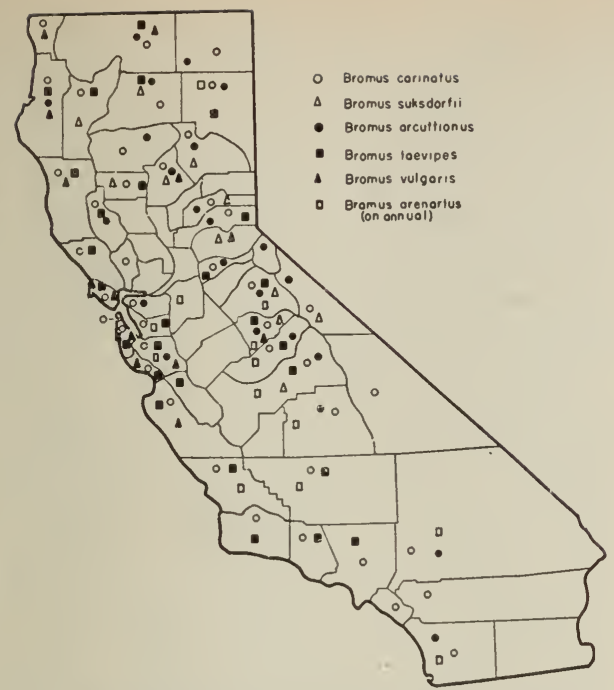

Fig. 15. Distribution of perennial bromegrasses.

brome, Orcutt brome, and Suksdorf brome.

Annuals: The annual brome grasses are important constituents of the forage in the valley and foothill ranges of California. (Fig. 16.) In the southern part of the state, and some other areas at lower elevations, they make up a major portion of the early forage crop on the annual ranges. The most important and widespread annual bromes are: Soft chess,

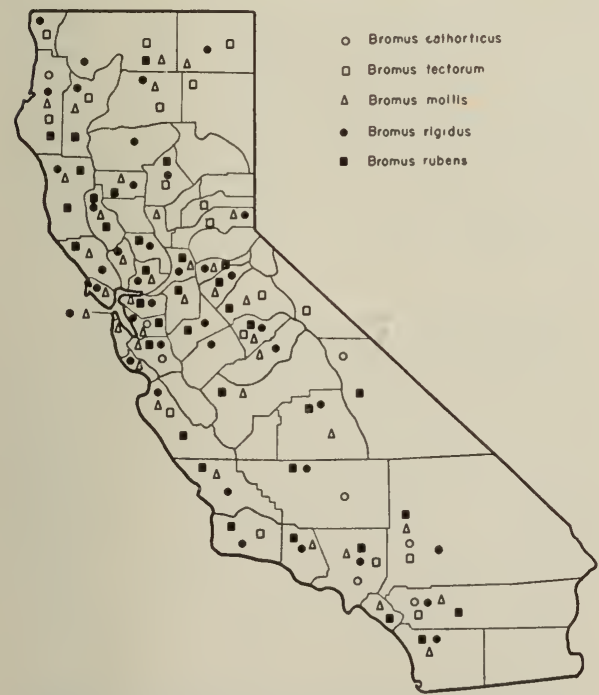

Fig. 16. Distribution of annual bromegrasses.
Australian chess, ripgut brome, red brome, and downy chess.

\section{Key to Species}

Plants perennial (or B. catharticus a winter annual)

Plants with creeping rhizomes 4. B. inermis Plants without creeping rhizomes

Spikelets flattened, the florets keeled

Florets pointed or awn-tipped only

2. B. catharticus

Florets distinctly awned

Sheaths scabrous to sparsely pilose; panicles usually open; spikelets loose, the relatively long rachilla joints exposed in blossoming time

1. B. carinatus

Sheaths, at least the lower, densely backwardly villous; panicle narrow, the stiff branches ascending; spikelets compact, the florets overlapping.

3. B. stamineus

Spikelets not flattened; the florets rounded on the back

Panicle narrow, the branches erect

8. B. suksdorfii

Panicle open, the branches spreading or drooping

Panicle branches short, stiffly spreading; blades short 7. B. orcuttianus Panicle branches long, more or less drooping; blades elongate

Sheaths and blades pilose; first glume 1-nerved; lemmas sparsely pubescent along the margin or nearly glabrous 5. B. vulgaris Sheaths and blades glabrous; first glume 3-nerved; lemmas densely pubescent along the margin

6. B. laevipes

\section{Plants annual}

Lemmas broad; florets not sharp-pointed at base

Panicle contracted; spikelets short-pediceled

9. B. mollis

Panicle open, the branches ascending or spreading

10. B. arenarius

Lemmas narrow, acuminate, the awns long

Panicle a dense ovoid head 12. B. rubens Panicle open, nodding, the branches spreading or drooping

Spikelets 5-7 cm long; awns rigid

11 . B. rigidus

Spikelets 1:5-2 cm long; awns not rigid 13. B. tectorum 


\section{Perennial Bromes}

1. CALIFORNIA BROMEGRASS (Bromus carinatus) is $2-31 / 4 \mathrm{ft}(60-100 \mathrm{~cm})$ tall, with stout culms, abundant foliage more or less finely hairy, the blades flat, roughmargined; panicles usually large, open, the large purplish spikelets borne towards the ends of the long spreading branches. Dwarfed plants commonly have narrow panicles. (Fig. 17.)

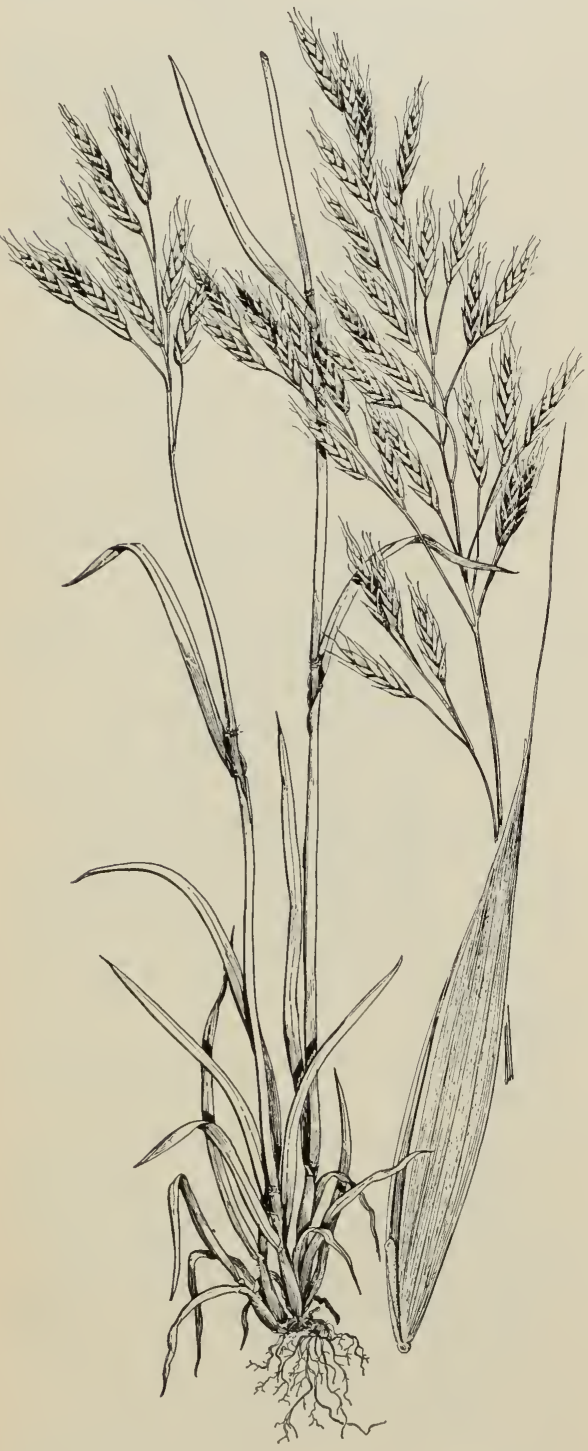

Fig. 17. California bromegrass (Bromus carinatus).
Distribution and habitat: California bromegrass occurs at elevations from sea level to $10,000 \mathrm{ft}$. Except for small areas, stands are scattered and the height is reduced at high elevations. It thrives best in the ponderosa pine type, or on lands of like elevation. Most common habitats are open woodland, grassy hillsides where the soil is good, and well-drained parks.

Forage value and reproduction: Although California bromegrass is relished by all classes of stock during the growing season, mature plants become harsh and fibrous. Even so, sheep relish the nutritious seed heads, and lambs fatten rapidly and economically when an abundance of well-filled seed heads is available (10). When grazed off early in the season, this species produces a good aftermath of foliage which is devoured with relish even late in the autumn. As its early spring growth is made at the expense of carbohydrates stored in the roots and stem bases the previous autumn, some form of protection must be given to the late growth of plants in order to maintain adequate stands. Protection in the form of deferred and rotation grazing, where plants are not grazed continuously during any one season nor at the same time in consecutive years, enables California bromegrass to deposit the required stores of carbohydrates (37). Seeds ripen in May and June in the lower elevations, and at higher elevations are mature and cast by late August. In favorable years, properly managed stands produce good seed crops.

\section{RESCUEGRASS (Bromus catharticus)} is a short-lived perennial or winter annual, 2-31/4 ft $(60-100 \mathrm{~cm})$ tall, with long rough blades and large drooping panicle (small and narrow in dwarfed plants) of large spikelets. Introduced from South America. Includes many "strains" some of which are annuals, others short-lived perennials. (Fig. 18.)

Distribution and habitat: Rescuegrass occurs most abundantly in the southern 


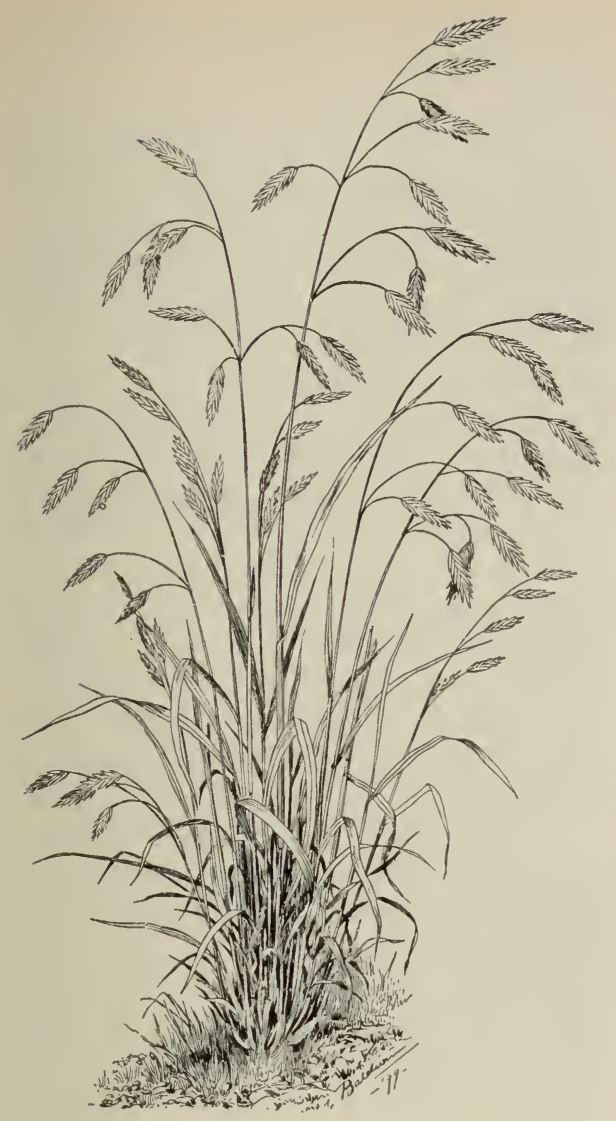

Fig. 18. Rescuegrass (Bromus catharticus).

half of California up to $3500 \mathrm{ft}$. The best growth is on rich, light soils of medium moisture. Under favorable conditions growth is rapid and luxuriant. Rescuegrass is somewhat tolerant of shade and succeeds in making early growth under stands of trees, especially along water courses and on the lower bench lands.

Forage value and reproduction: Wherever this species grows well it is valuable both for pasture and hay. The name "rescue" indicates the high esteem stockmen have for the plant as early forage on southern ranges. All classes of stock are fond of the leafage and seed heads, especially where winter growth is good. Although normally a winter annual, rescuegrass, if grazed before seeding, lives for several seasons and produces a large amount of herbage. The seed ripens in May and June, a large seed crop being produced under favorable conditions.

3. HARLAN BROMEGRASS (Bromus stamineus) is a tufted short-lived leafy perennial, 14-25 in (40-60 cm) tall; lower sheaths densely backwardly villous; panicle 9-17 cm long, the spikelets somewhat crowded on the rather short branches.

In recent years Harlan brome was discovered growing in a nursery on the University of California campus where it presumably had escaped from an introduction from Chile made by the late Professor P. B. Kennedy. Dr. J. Harlan, a graduate student under Dr. G. L. Stebbins, Jr., has included this species in his studies of bromes.

Dr. R. M. Love has stated that Harlan brome is adapted to a wide variety of conditions, and that it produces seed even under unfavorable climatic conditions. In poor sites it grows as an annual. It produces abundant winter and spring leafage and is recommended for range reseeding where California brome is present. Seed is available in commercial quantities.

4. SMOOTH BROMEGRASS (Bromus inermis) is leafy, 2-31/4 ft $(60-100 \mathrm{~cm})$ tall, with creeping rhizomes; panicles rather narrow but loose, erect, the numerous, often purplish spikelets $2-2.5 \mathrm{~cm}$ long, the lemmas awnless. Introduced from Europe. (Fig. 19.)

Distribution and habitat: Smooth bromegrass is one of the best domesticated species introduced into the far western mountains (12). In California it is adapted to the northeastern region where good stands are usually obtained in fairly moist, rather deep soils. Once established, smooth brome develops an extensive root system which binds the soil firmly and enables the plant to withstand grazing and severe drought. It has been widely used in the artificial reseeding of mountain ranges and has proved well adapted 


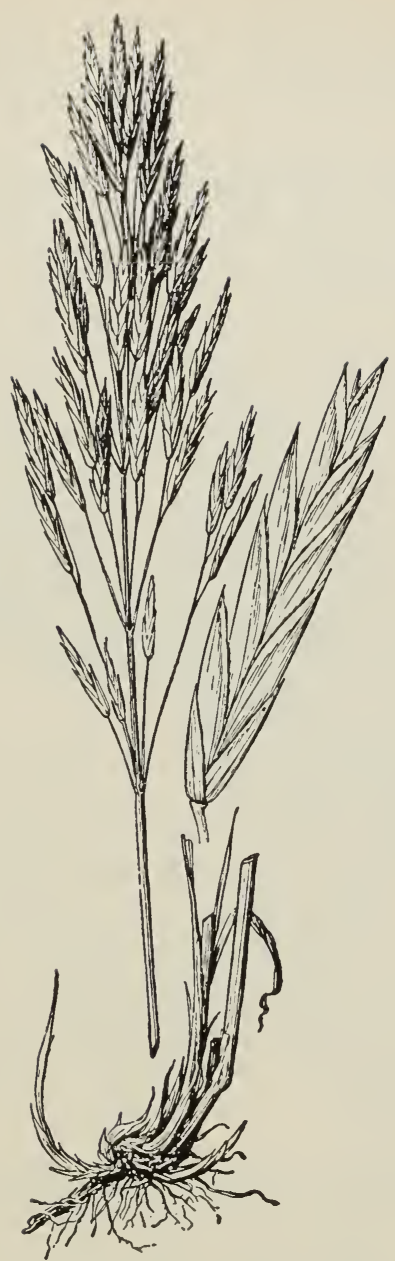

Fig. 19. Smooth Bromegrass (Bromus inermis).

for the rehabilitation of overgrazed, eroded, and burned-over range lands (7).

Forage value and reproduction: Smooth brome is valuable for pasturage when growing in pure stands. It is also valuable for hay when planted on good sites in mixture with alfalfa, yielding $11 / 2$ to $33 / 4$ tons per acre. The persistent rhizomes and long-lived habit of this grass make it an exceptionally good forage producer on far western ranges. Smooth brome is equal to timothy in feeding value, and chemical analysis indicates the high nutritive content is maintained until seed maturity (23). At elevations up to 9000 feet it normally produces an abundance of viable seed.

\section{NARROW-FLOWERED BROMEGRASS}

(Bromus vulgaris) is $21 / 2-4 \mathrm{ft}(75-120$ $\mathrm{cm}$ ) tall with sparsely pilose foliage, the blades to $10 \mathrm{~mm}$ wide; panicle nodding, spikelets long and narrow, the lemmas awned and sparsely pubescent near the margin or nearly glabrous.

Distribution and habitat: Narrowflowered bromegrass is widely distributed throughout the northern part of the state from sea level to about $7000 \mathrm{ft}$, where it is of value as stock food both on the winter and summer ranges. The largest herbage production is at intermediate elevations, but pure stands are seldom seen even under the best conditions. The grass occurs typically in woodlands and shady ravines.

Forage value and reproduction: Narrow-flowered brome has high rank as forage. In palatability and amount of forage produced it is second only to California bromegrass. The seed habits are fairly strong and reproduction is rapid under favorable conditions.

\section{WOODLAND BROMEGRASS (Bromus} laevipes) resembles narrow-flowered brome, but the foliage is glabrous, the blades somewhat narrower, and the lemmas densely pubescent along the margin.

\section{ORCUTT BROMEGRASS (Bromus or-} cuttianus) is relatively stout, $21 / 2-31 / 2 \mathrm{ft}$ (80-125 cm) tall, leafy below, nearly naked above, the blades shorter, firmer; panicle 10 to $15 \mathrm{~cm}$ long, often yellowish; branches stiffly spreading; lemmas scabrous, awned.

Woodland and Orcutt bromegrasses occur in woodlands at intermediate elevations, commonly growing in association with California and narrow-flowered bromegrasses, but are less abundant than these. In forage value and reproduction the Woodland and Orcutt bromes are similar to the associated grasses named. 
8. SUKSDORF BROMEGRASS (Bromus suksdorfii) is not so tall, the leaves softer, the short panicle branches erect or narrowly ascending; lemmas appressed, pubescent.

Suksdorf brome is a high mountain grass occurring from about 7000 to 10 ,$000 \mathrm{ft}$. It occupies roughly wooded areas and exposed slopes, much of which is not readily accessible to stock. While the leafage is palatable to grazing animals, the plant grows so sparsely over the greater part of the range as to yield but a small amount of herbage.

\section{Annual Bromes}

9. SOFT CHESS (Bromus mollis) is $1-2 \frac{1}{2}$ ft $(30-80 \mathrm{~cm})$ tall, in tufts, softly pubescent throughout, with dense panicles 5-10 $\mathrm{cm}$ long, of soft spikelets, the florets with slender awns 6-9 mm long. A native of Europe. (Fig. 20.)

Distribution and habitat: Soft chess is found throughout the state but is especially common in the coastal region from sea level up to 4000 feet. It is most common on clay loam and sandy soils but grows well on all soils that are well drained.

Forage value and reproduction: In forage rating soft chess ranks highest of the annual bromes, producing excellent forage when young. With its short, soft awns it can be grazed without injury even after seed maturity. On the San Joaquin Experimental Range (61) soft chess is reported to be the best of the annual grasses. The report states:

During the summer it has thus far been rated as the most important forage plant in the area. Soft chess also provides considerable winter feed but is grazed most heavily at the time it is reaching maturity, just after broadleaf filaree has begun to dry. In 1936, for example, it composed nearly 60 per cent of the forage at this growth stage. The seeds do not shatter readily and the plants are grazed extensively during the summer. Because of this, the grazing animals get more nutriment than they otherwise would from the dry stalks and leaves alone.

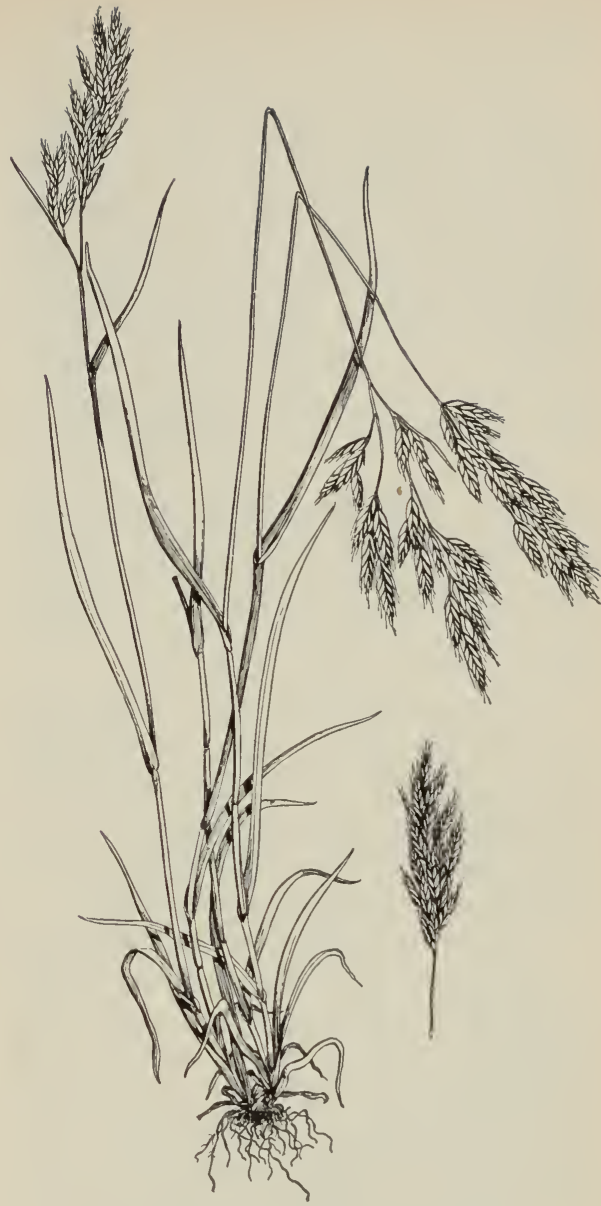

Fig. 20. Soft chess (Bromus mollis).

Chemical analyses (13) of soft chess at successive growth stages bear out the foregoing statement on the nutrient value of this plant. It was found to contain a relatively high percentage of protein at the time of blossoming, remaining high even after maturity because of the retention of the seeds. Soft chess produces a large, viable seed crop that matures in May and June, but is not shed until many weeks later.

10. AUSTRALIAN CHESS (Bromus arenarius) is $6-16$ in $(15-40 \mathrm{~cm})$ tall, softly pilose, the open nodding panicles 3-6 in (8-16 mm) long, the slender branches and pedicels strongly flexuous; spikelets 
with awns 10 to $16 \mathrm{~mm}$ long. A native of Australia.

Australian chess occupies dry sites and is fairly common in the Mojave desert and the foothills of the San Joaquin Valley. (Fig. 15.) Because of its scattered growth and the fact that leafage and seed heads are conspicuously hairy, its palatability ranks as intermediate. When young the entire available growth is taken with that of associated species, such as soft chess, foxtail fescue, and filaree.

11. RIPGUT (Bromus rigidus) is mostly $11 / 2^{-2} \mathrm{ft}(40-60 \mathrm{~cm})$ tall; foliage loosely pilose; panicle of relatively few large long-awned spikelets. A native of the Mediterranean region. (Fig. 21.)

Distribution and habitat: This species occurs generally throughout the annual type at elevations from sea level up to the ponderosa pine type. Ripgut seldom forms pure stands but frequently constitutes a fair proportion of the type.

Forage value and reproduction: In the early growth stages and until the plants head out in April and May, ripgut ranks high as a forage producer. A crude protein content of nearly 15 per cent just before flowering (13) may help to explain why the herbage is relished by cattle in the fore part of the grazing season.

At maturity the awns are particularly objectionable to all classes of stock. Accordingly, ripgut has also been called needle brome and devilgrass. However, the name "ripgut" probably better emphasizes the penetrating power of the hard sharp florets characteristic of this species at maturity. Careful management of ranges infested with this grass is required to favor the seeding and establishment of the more desirable forage grasses.

12. RED BROMEGRASS (Bromus rubens) is mostly $10-20$ in $(20-40 \mathrm{~cm})$ tall, leafy at base with erect, very dense, ovoid reddish or purplish panicles of long-awned spikelets, the awns 18-22 mm long, rigid, scabrous. (Fig. 22.)

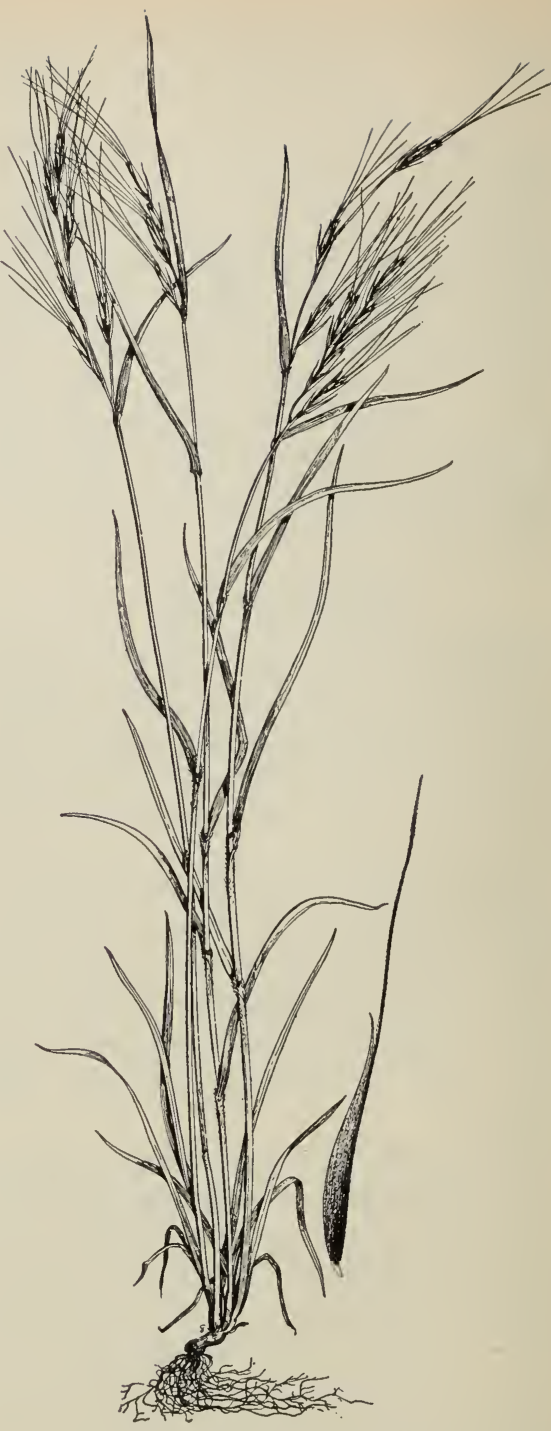

Fig. 21. Ripgut (Bromus rigidus).

Distribution and habitat: Red brome, also known as foxtail chess, is another introduced annual. This species is fairly widely distributed on the winter ranges throughout the state, and appears well adapted to shallow soils or clayey lands where the better perennials are mostly wanting. Red brome sometimes forms a dense cover and often occupies large areas to the practical exclusion of other plants. 


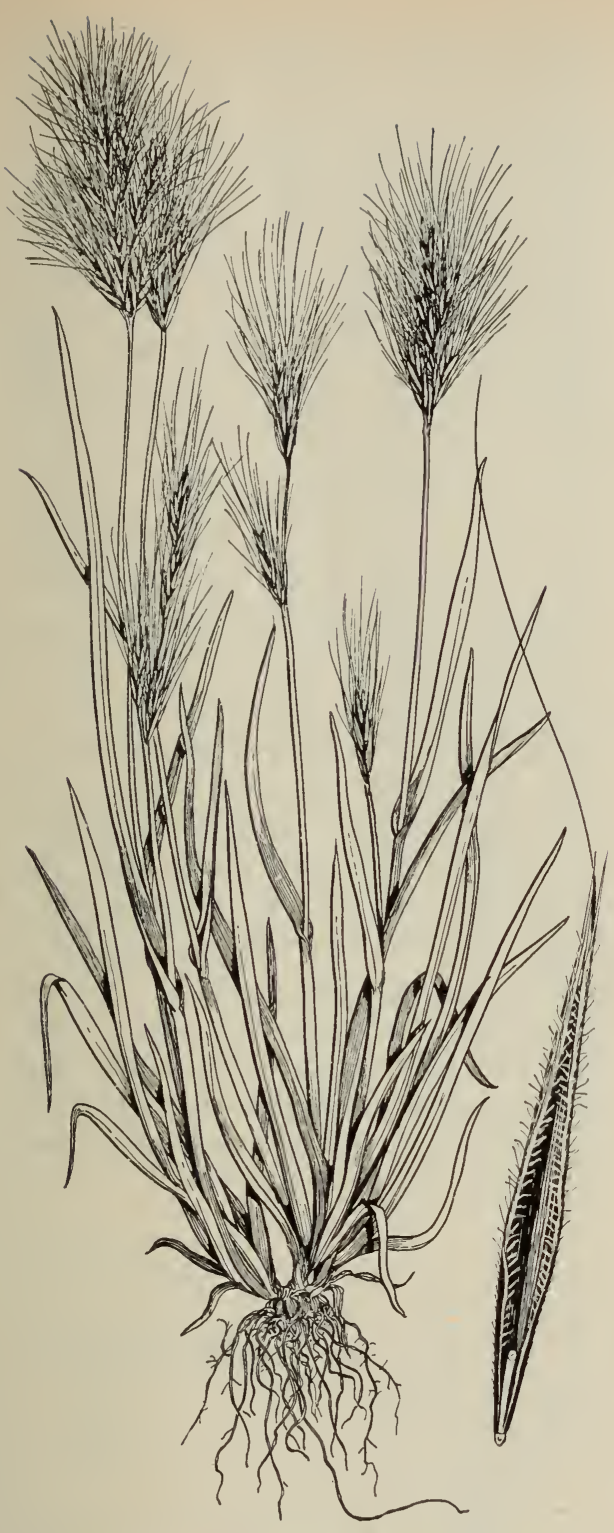

Fig. 22. Red bromegrass (Bromus rubens).

Forage value: Investigators on the San Joaquin Experimental Range (61) found that red brome furnishes fair feed during the winter, but that after maturity the herbage is not sought by livestock. The awns are rigid but not especially injurious. Chemical analysis of the forage samples collected on the Experimental Range revealed red brome to have about the same nutritional value as soft chess (13).

13. DOWNY CHESS (Bromus tectorum), also called cheatgrass, June brome, forms dense tufts $1-2 \mathrm{ft}(30-60 \mathrm{~cm})$ tall, the whole plant softly hairy; panicle manyflowered, mostly 10-12 cm long, the hairy spikelets nodding on flexuous branches. A native of the Mediterranean region. (Fig. 23.)

Distribution and habitat: Downy chess occurs principally on lava plateaus in northeastern California and to a lesser extent in the annual foothill type in the central and southern portion of the state. It grows on the poorer soils in the semi-

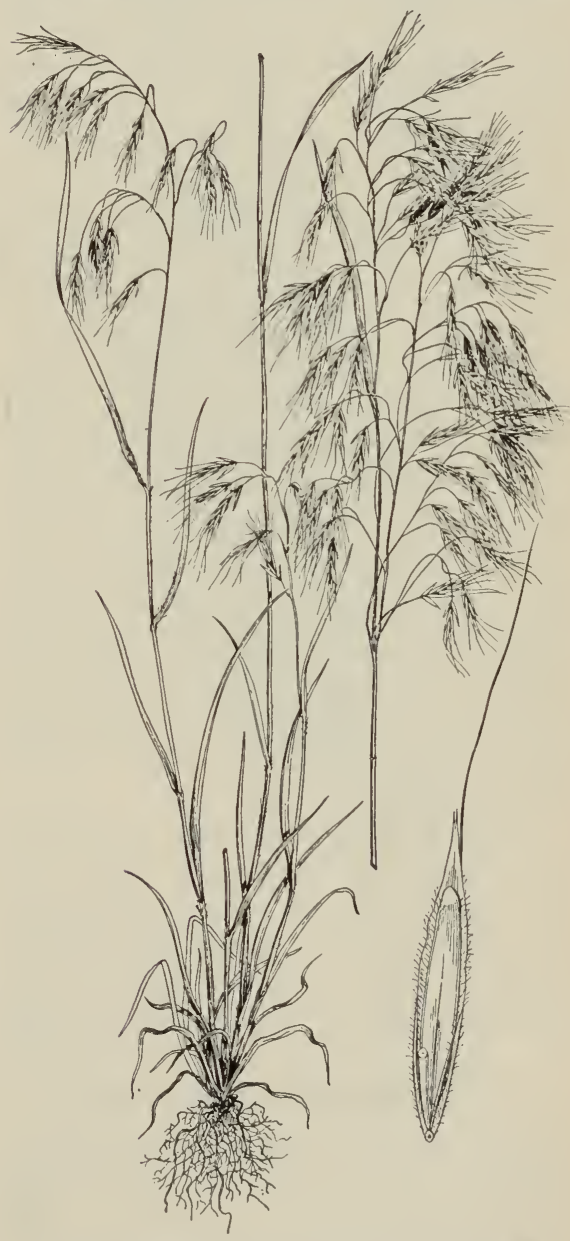

Fig. 23. Downy chess (Bromus tectorum). 
arid sections, where under heavy grazing it has replaced the more desirable forage plants.

Forage value and reproduction: Downy chess furnishes considerable early spring grazing, and remains tender and palatable until about the middle of May when it begins to mature and turn reddish (10). Although the awns are objectionable, as in red brome and ripgut, some grazing is provided by the dry plants after softening by late season rains. The best grazing value of downy chess is chiefly confined to a few weeks in the spring.

In Nevada (11) downy chess was found to compare favorably in nutrient values with associated perennialsnamely, bluebunch wheatgrass, Idaho fescue, and Sandberg bluegrass, at similar stages of growth and maturity. Forage production (dry weight per square foot of density) was slightly greater than the amount produced by Idaho fescue, about twice the amount produced by Sandberg bluegrass, but less than half the amount produced by bluebunch wheatgrass.

Studies in Idaho (26) revealed that forage yields of downy chess in early spring are drastically reduced if the area has been burned over early the previous year. Further research is needed to determine the value of this grass. In the meantime, good management of downy chess ranges is needed to reduce soil losses and maintain soil productivity. Production is highly variable from year to year, and soil loss may be high in seasons when the stand is sparse.

Where grazing is properly regulated and fires prevented, downy chess tends to be replaced by the more valuable species. An abundance of seed is produced except in years when the heads are attacked by a smut (Ustilago bromivora).

\section{FESCUEGRASSES (FESTUCA)}

Fescuegrasses are rather tall perennials (one low alpine fescue) and low or tall annuals; spikelets in narrow or open panicles; lemmas mostly awned.
Twenty-three fescuegrasses grow naturally on California range lands, 11 perennials and 12 annuals. Only some six species contribute appreciably to the forage crop, the rest occurring so sparsely as to merit little consideration.

Perennials: The perennials have a wide elevational distribution and are most abundant on deep, well-drained soils where they form a fair portion of the subclimax or climax herbaceous cover. On some conservatively grazed areas in northern California they are abundant enough to contribute appreciably to the forage crop. (Fig. 24.) The best stands are found at medium to high elevations in well-drained open timber sites and on high mountain slopes and glades. All are bunchgrasses and rank high as forage. The characteristically large amount of fine basal leafage is sought by all kinds of livestock from early spring until late in the season, well after seed maturity. Seed habits are fairly strong, and satisfactory reproduction may be expected where deferred and rotation grazing are practiced. The most widely distributed and important perennials are: Idaho fescue, western fescue, greenleaf fescue, tall

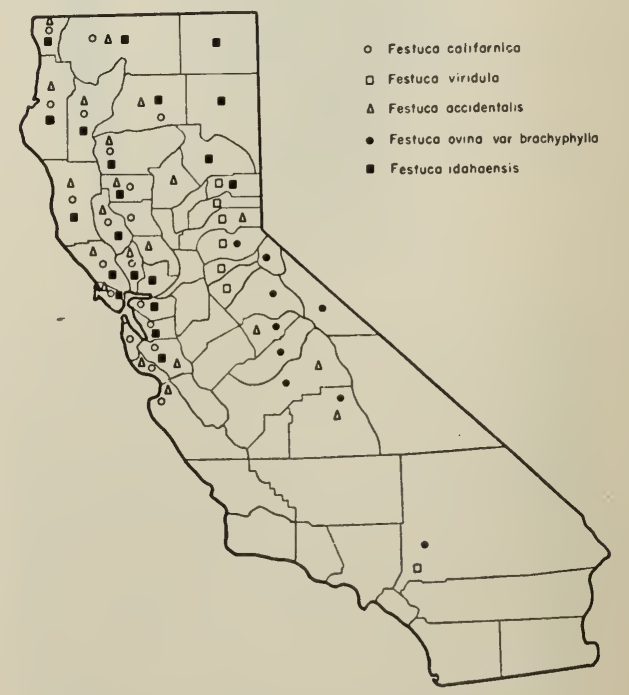

Fig. 24. Distribution of perennial fescues. 
fescue, alpine sheep fescue, and California fescue.

Annuals: The annual fescues occur in economic abundance chiefly in the valleys, foothills, and lower timber regions. In the foothills they contribute abundantly to the winter and spring forage. Some species are among the first plants to invade overgrazed areas, and heavily packed or thin soils. Foxtail fescue is the most prominent range species.

\section{Key to Species}

Plants perennial

Blades flat, coarse; culms tall, stout

Panicle narrow, the branches narrowly ascending; collar and mouth of sheath glabrous

4. F. arundinacea

Panicle open, the branches spreading or drooping; collar and mouth of sheath hairy

6. F. californica

Blades inrolled or very narrow (those of the culm flat or loosely rolled but soft in F. viridula)

Lemmas awnless

3. F. viridula

Lemmas awned

Plants in dense low tufts at upper altitudes 5. F. ovina var. brachyphylla Plants 1 to $3 \frac{1}{4} \mathrm{ft}(30-100 \mathrm{~cm})$ tall Blades rough, rather stiff; panicle narrow

1. F. idahoensis

Blades smooth, soft; panicle open

2. F. occidentalis

Plants annual

Lemmas with long hairs on the margin

Lemmas, without hairs on the margin

7. F. megalura

First glume about half as long as the second

8. F. dertonensis

First glume minute

9. F. myuros

\section{Perennial Fescues}

1. IDAHO FESCUE (Festuca idahoensis) is mostly $2-31 / 4 \mathrm{ft}(60-100 \mathrm{~cm})$ tall, densely tufted with abundant fine rough basal foliage; panicles narrow, 4-8 in (10-20 cm) long; spikelets 5-7 flowered, the awns 2-4 mm long. (Fig. 25.)

Distribution and habitat: Idaho fescue occurs most abundantly in the northern half of the state between elevations of 3000 and $7500 \mathrm{ft}$, the best stands being found on fairly dry, deep, well-drained

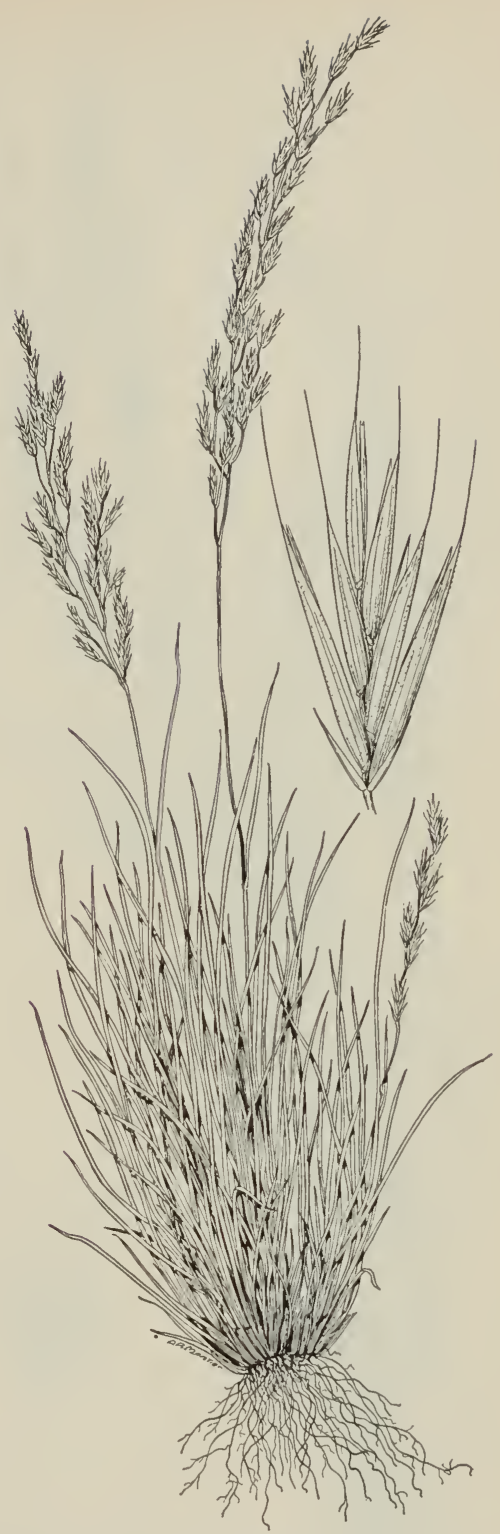

Fig. 25. Idaho fescue (Festuca idahoensis).

loamy or sandy soils. (Fig. 24.) Favorite habitats are open timber, notably ponderosa pine and lodgepole pine, and well-drained meadows and glades. Fair to good stands are sometimes found in thin soils of benchland, and on hillsides of various slopes and exposures, where this species competes for space with other 


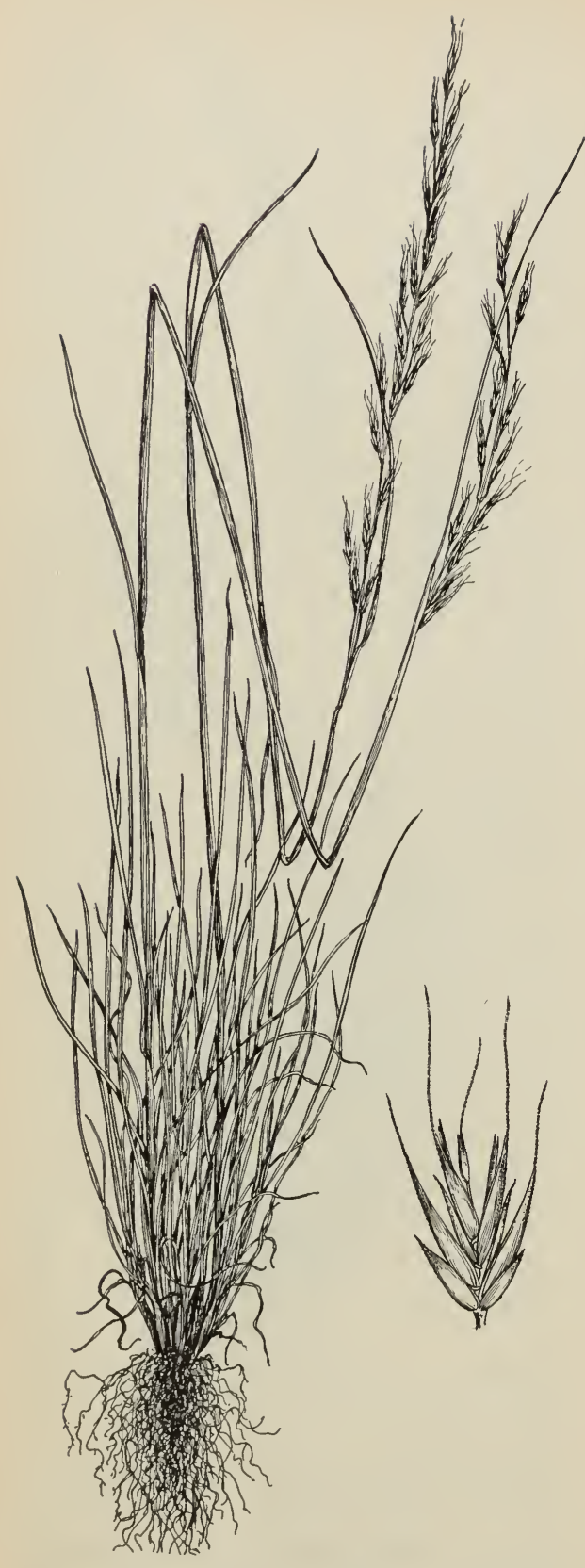

Fig. 26. Western fescue (Festuca occidentalis).

perennial bunchgrasses, forbs, and low shrubs. It does not endure deep shade.

Forage value and reproduction: Idaho fescue has high rank as forage, the leafage being sought from early spring to autumn by cattle, horses, and sheep, as well as by deer. Like most bunchgrasses, the herbage grows fibrous and less palatable upon approach of maturity in the autumn. Even at that time horses feed extensively upon it, and other animals consume the basal leafage about as well as that of most bunchgrasses. The mature growth is taken well by all stock in autumn and winter after rains have stimulated production of new leafage, for then the old growth is grazed with the young. Stands are well maintained under good management, for seed production and seed viability are fair to good (48).

2. WESTERN FESCUE (Festuca occidentalis) is densely tufted, the tall shining culms extending above an abundance of fine soft foliage; panicle 3-6 in (7-15 $\mathrm{cm}$ ) long, the slender distant branches naked at base; spikelets 3-5 flowered, the awns about $5 \mathrm{~mm}$ long. (Fig. 26.)

Distribution and habitat: Western fescue occurs from Monterey County (Big Sur) northward between elevations of about 500 to $8000 \mathrm{ft}$. Favorite habitats are oak woodland and the fertile redwoods, but it is also found on shaded rocky slopes and brushland of thin soils.

Forage value and reproduction: The herbage is highly palatable to all kinds of livestock, partly because of the abundant, rather delicate basal leaves. Even the flower stalks are taken by cattle and horses up to seed maturity. The stands, however, are seldom dense, and consequently the grass does not contribute as much feed as Idaho fescue on ranges where the two are associated. The relative sparseness of stands seems to be related to the seed habits, which are not particularly strong, and to the fact that the herbage is sought throughout the grazing season.

3. GREENLEAF FESCUE (Festuca viri$d u l a)$ is loosely tufted, mostly $2-31 / 4 \mathrm{ft}$ $(50-100 \mathrm{~cm})$ tall, reddish at base, with 
abundant soft foliage; panicle open, 3-6 in $(8-15 \mathrm{~cm})$ long; spikelets 3-6 flowered, 10-12 mm long, often purple-tinged.

Distribution and habitat: The most extensive stands of greenleaf fescue occur in the northern Sierra Nevada between 7000 and $10,000 \mathrm{ft}$ (2). Another distributional unit is found in the San Bernardino Mountains of southern California. (Fig. 24.) It is a common species on drained meadows, plateaus, grassy slopes, and open timberland. On deep, loamy soils this grass often forms the bulk of the herbaceous cover.

Forage value and reproduction: The forage rating of greenleaf fescue is high, no fescue perhaps outranking it in this respect. From early spring until the end of the grazing season all kinds of livestock feed greedily upon the herbage. A portion of the basal leafage remains green late in the autumn, thus retaining a relatively high palatability, even for sheep, after the herbage of many other grasses has fully matured. Seed production of vigorous plants is abundant, and reproduction is good where the large seeds are trampled into the ground by late autumn grazing (47).

4. TALL FESCUE (Festuca arundinacea) is robust, 3-6 ft $(90-180 \mathrm{~cm})$ tall; panicle to $1 \mathrm{ft}(32 \mathrm{~cm})$ long, narrow but loose, spikelets mostly 12 to $15 \mathrm{~mm}$ long.

Tall fescue, an introduced perennial, is being tested for its usefulness in the artificial reseeding of rangelands, including burned-over brushland. These introductions have resulted in occasional limited establishment of the grass in the native stand at intermediate to moderately high elevations. Although the growth of mature plants tends to be coarse, the herbage when green and succulent is taken by all livestock.

5. ALPINE SHEEP FESCUE (F estuca ovina var. brachyphylla) is low and tufted with a dense mass of short basal foliage; panicles narrow; spikelets short-awned. (Fig. 27.)

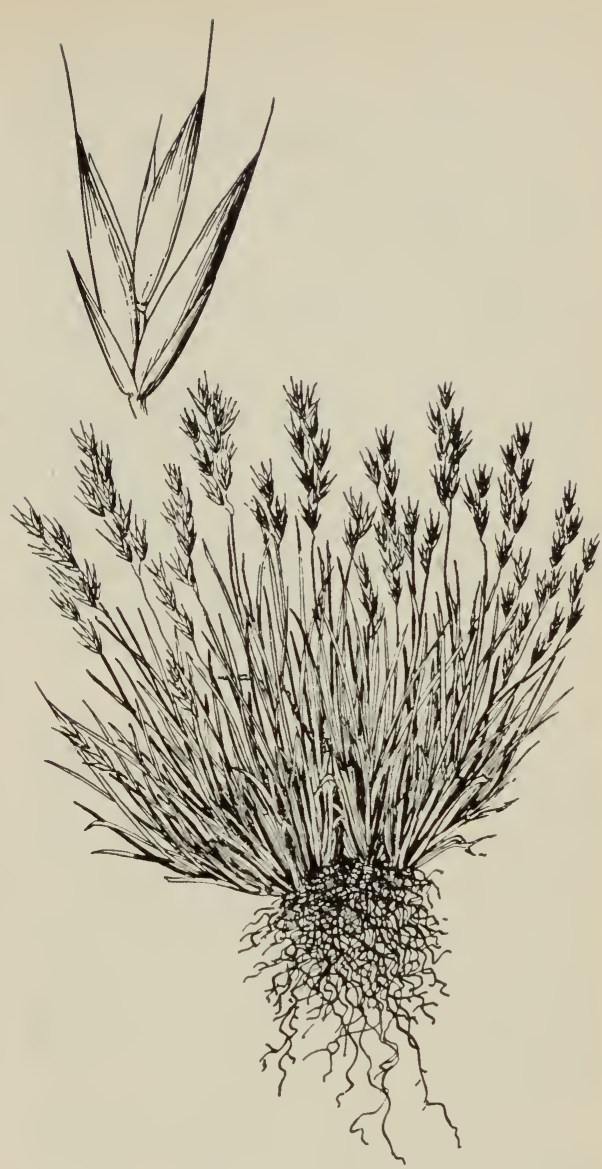

Fig. 27. Alpine sheep fescue (Festuca ovina var. brachyphylla).

Distribution and habitat: Alpine sheep fescue occurs most extensively in the Sierra Nevada from Inyo to Alpine Counties, and in the San Bernardino Mountains between 8000 and 12,000 ft. (Fig. 24.) The distribution is unusually wide elsewhere in the West. Favorite habitats are parks, open woodlands, meadows, benchlands, and hillsides where it occupies shallow to deep soils of diverse origin and character. Although usually growing in association with other bunchgrasses and forbs, it occasionally dominates the stand over restricted areas.

Forage value and reproduction: The forage value is of highest quality for all kinds of livestock. Growth is particularly 
early and rapid in the spring when it is taken in preference to many other plants rated as fair to good forage. The large amount of fine basal leafage is cropped eagerly by sheep practically up to maturity, while the fully cured growth is grazed moderately by cattle and closely by horses. This high palatability doubtless accounts for its decline in many areas under intensive grazing, despite its relatively strong seed production. Alpine sheep fescue has been used in artificial reseeding of mountain ranges with varying success. It has also been used for farm pasture establishment, and limitedly as a lawn grass, frequently with good success on sandy or loamy soils of medium productivity.

6. CALIFORNIA FESCUE (F estuca californica) forms large coarse clumps, mostly $3 \mathrm{ft}$ or more (90-120 cm) tall; blades harsh, flat or rolled, with a fringe of short hairs at the base; panicle open, mostly $8-10$ in (20-25 cm) long, the branches in distant pairs; spikelets 4-5 flowered, 10-18 mm long, the lemmas sharp-pointed or awn-tipped.

Distribution and habitat: The elevational range of California fescue is from near sea level to about $5000 \mathrm{ft}$. It is essentially a northern California species, occurring from Monterey (Big Sur) to the Oregon line in the coastal mountains. (Fig. 24.) It is most abundant in open ground and in open woods where it occupies a variety of soils. Seldom does it form a dense stand over extensive areas.

Forage value and reproduction: The forage rating is the lowest of the perennial species here mentioned. The herbage is coarse, and is harsh after approaching maturity. Sheep feed on the plant only in early spring, and cattle to midsummer, but horses relish it fairly well throughout the normal grazing season. Another reason for the low forage rank is the large number of seed stalks. The amount of seed produced is generally large.

\section{Annual Fescues}

Of the twelve annual species of Festuca only three are sufficiently abundant and contribute sufficient forage to justify mention. First in importance is foxtail fescue; among others, false foxtail fescue

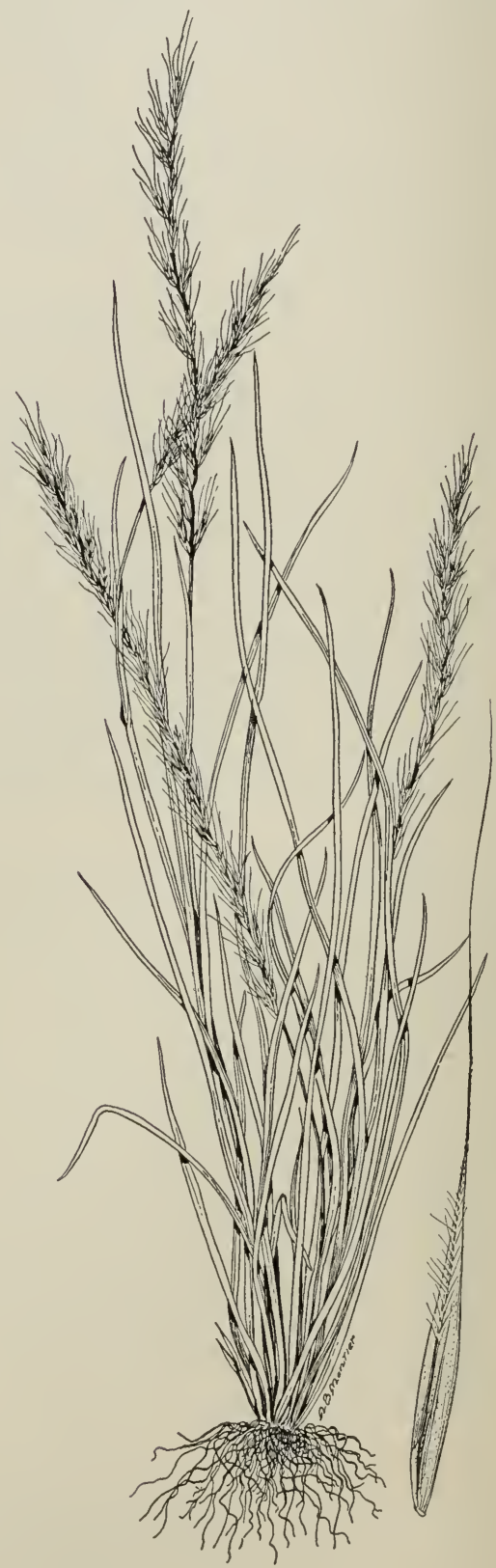

Fig. 28. Foxtail fescue (Festuca megalura). 
occasionally produces stands of moderate density in restricted areas.

7. FOXTAIL FESCUE (Festuca megalura), sometimes called six weeks fescue, is a native species recognized by its narrow many-flowered panicle of long-awned spikelets with lemmas ciliate on the margin. (Fig. 28.)

Distribution and habitat: Foxtail fescue occurs along the coast and the interior valleys and foothills from sea level to some $4500 \mathrm{ft}$. Favorite habitats are open thin or heavily packed arid soils, and recent chaparral burns. Moderate to heavy grazing seems to favor its abundance at the expense of more palatable grasses. On sample areas of the San Joaquin Experimental Range, near Fresno, foxtail fescue was listed as the second most common grass, where, over a period of five years, it composed from 9 to 17 per cent of the total cover. Moreover, it accounted for from 18 to 40 per cent of the grass vegetation for four of the five seasons of measurement, and was the third most abundant plant on the range (61). The stand may fluctuate widely from year to year, but tends to be distributed rather uniformly over extensive foothill areas.

Forage value and reproduction: Forage value of foxtail fescue is seasonally fairly good for cattle and horses, and fair for sheep, and the volume of leafage produced is large. The fact that it grows in association with various palatable forbs, such as filaree (Erodium spp.), trefoil (Lotus spp.), and popcorn flower (Plagiobothrys spp.) probably accounts in part for its moderate to fair utilization in the dry state in summer and fall.

The chief objection to foxtail fescue as forage is its early maturity-usually occurring between May 1 and May 15and the low nutrition of the forage thereafter (13). Accordingly, where foxtail fescue composes a large proportion of the forage, it is good practice to supplement the range in summer and fall with pro- tein-rich concentrates, and perhaps some green roughage to provide needed vitamin A.

Seed production is large and the seed viable even in poor growth years.

8. EUROPEAN FOXTAIL (Festuca dertonensis).

\section{FALSE FOXTAIL FESCUE (F estuca myu- ros).}

These grasses, very similar and both natives of Europe, occur most abundantly on the coastal ranges of the state, where they grow in scattered stands. Their habit of growth, time of maturity, and nutritive pattern are similar to those of foxtail fescue.

\section{BLUEGRASSES (POA)}

Bluegrasses are slender perennials or annuals, in tufts or with creeping rhizomes, forming a sod, with rather soft foliage, the blades long and narrow and with a boat-shaped tip; panicles narrow or open, the spikelets small, awnless.

Of the 33 bluegrasses growing on California range lands, 29 are perennials and four annuals. Of these only 11 species are abundant enough to contribute appreciably to the forage crop.

Perennials: As a group, the perennials are widely distributed in northern California, and at high elevations in other sections. They thrive on cool mountain ranges, where they furnish grazing from early spring to late summer, and remain palatable and nutritious throughout the season. (Figs. 29, 30.) Although occurring on a variety of sites, stands are usually best on rich, moist, well-drained soils, and are characteristic of meadows, grassy parks along stream banks, shaded woodlands, and in open sagebrush and wheatgrass types (10). Perennial bluegrasses are comparatively abundant in the development of a stable or climax cover. They nearly always replace the brome grasses, but frequently give way to certain species of needlegrasses and wheatgrasses (33). 


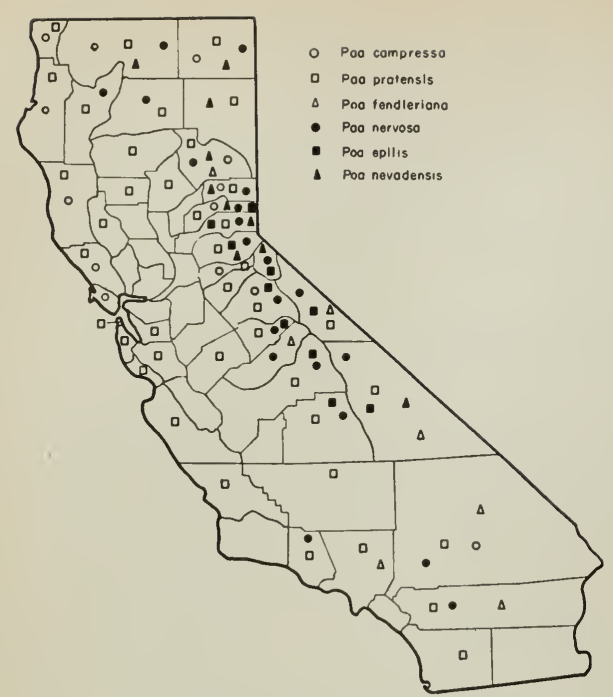

Fig. 29. Distribution of bluegrasses.

Relished by both livestock and wild game, the perennials rank among the most palatable range grasses. Although primarily used for pasturage, a few species are cut for hay. Most bluegrasses are good seed producers. Kentucky bluegrass and Canada bluegrass have the added means of propagation by rhizomes and are commonly used to reseed depleted mountain range lands. Other im.

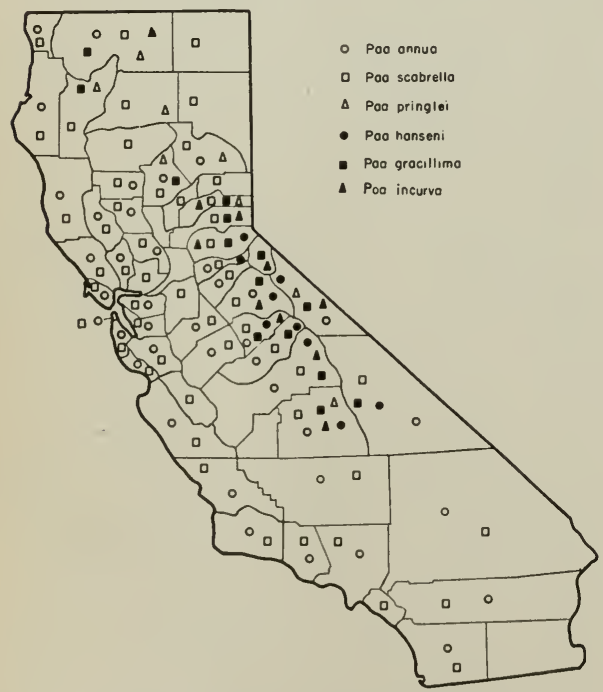

Fig. 30. Distribution of bluegrasses. portant California perennial bluegrasses are: muttongrass, pine bluegrass, Olney bluegrass, skyline bluegrass, Pringle bluegrass, Hansen bluegrass, Pacific bluegrass, and Nevada bluegrass.

Annuals: Annual bluegrasses occur in the more arid sections of the state. Several afford some early grazing in the deserts and foothills. Of these, only annual bluegrass $(P$. annua) is important as forage.

\section{Key to Species}

The authors are indebted to Dr. David A. Keck for his preparation of the accompanying key of Poa.

Plants annual. Commonly a dooryard weed; widespread at low elevations 11.P. annua Plants perennial

Creeping rhizomes present

Panicle open, pyramidal, its elongated lower branches lax and floriferous only in outer half; culms round

Lemmas glabrous or puberulent but not webbed at base; florets all female; rhizomes short. High montane 5. P. nervosa Lemmas with a tuft of cobwebby hairs at base; florets perfect; forming dense sods; very common $\quad$ 1. P. pratensis Panicle more contracted, oblong, its short lower branches not lax; lemmas not conspicuously webbed at base; forming thin sods; culms flattened, 2-edged; not common

2. P. compressa

Creeping rhizomes wanting; lemmas not webbed at base. All bunchgrasses

Lemmas glabrous or scabrid, but not pubescent or puberulent on lower part of nerves (see also $P$. scabrella)

Spikelets compressed, the lemmas keeled. All at high elevations

Lemmas less than $4 \mathrm{~mm}$ long; culms 10-25 cm high, often capillary

8. P. hanseni

Lemmas longer; culms stouter Lower lemmas mostly $6 \mathrm{~mm}$ or longer, the spikelet pale and shining; leaves firm, short, often recurved; culms mostly $20 \mathrm{~cm}$ or shorter. N. Calif. 7. P. pringlei Lower lemmas 4-5 mm long, the spikelet purple or green; basal leaves linear, elongated, culm leaves more 
or less flattened and wider; culms mostly $30-50 \mathrm{~cm}$ tall. Throughout the high Sierra Nevada

6. P. epilis

Spikelets little compressed, 6-8 $\mathrm{mm}$, the lemmas rounded dorsally, the keel obscure. A tall meadow grass of the Great Basin

10. P. nevadensis

Lemmas more or less hairy on back, keel or nerves, at least towards base (sometimes obscurely so and occasionally nearly glabrous in P. scabrella)

Spikelets compressed; lemmas keeled, very broad and rounded, villous on keel and marginal nerves. South and east of the Sierras

3. P. fendleriana

Spikelets little compressed, the lemmas rounded on back, crisp-puberulent towards base, the keel obscure

Spring-flowering and more or less ephemeral, summer-dormant; low elevations up to $5000 \mathrm{ft}$ or more; widespread 4.P. scabrella Summer-flowering and summer-active; montane to high alpine, mostly above $7000 \mathrm{ft}$

9. P. gracillima

\section{Perennial Bluegrasses}

1. KENTUCKY BLUEGRASS (Poa pratensis) at its best forms a complete sod, but usually grows in small patches, close together or distant, among other vegetation; it is $1-3 \mathrm{ft}(30-90 \mathrm{~cm})$ tall, the foliage soft and long; panicle open, the spikelets clustered towards the ends of the branches, the lower branches in a fascicle of five. (Fig. 31.)

Distribution and habitat: Although originally introduced from England, Kentucky bluegrass has become so widespread and abundant in some sections of the country that it is commonly regarded as a native. Stands in California are confined to northern coastal areas or cool mountain regions up to $10,000 \mathrm{ft}$. It will grow on a wide diversity of sites, but does best on well-drained loams rich in humus. Accordingly, this grass is found on the more productive mountain soils and moist sites, occurring in meadows, along streams, and in open and semishaded benchlands.

Forage value and reproduction: Ken-

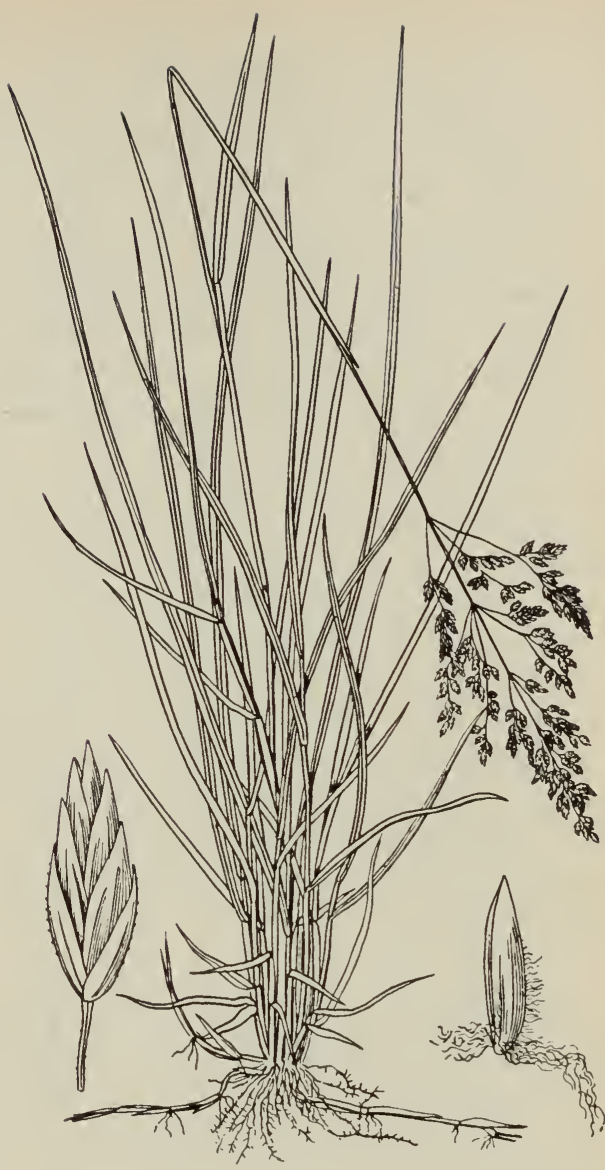

Fig. 31. Kentucky bluegrass (Poa pratensis).

tucky bluegrass furnishes nutritious forage relished by all classes of livestock, as well as by deer and elk. Before heading out in the spring, bluegrass usually contains nearly 20 per cent protein. Also, when kept from heading out, the percentage is nearly as high late in the season (39). If the moisture supply is ample and the temperature does not rise above $90^{\circ} \mathrm{F}$, the nutritious foliage remains green and palatable throughout the summer (10). Propagation by both seeds and rhizomes, even when heavily grazed, assures the successful reproduction of Kentucky bluegrass stands on favorable sites. Slowness of the species in establishing a stand has retarded its 
use for reseeding on some adapted sites. However, the permanence, heavy production of high quality forage, and ability of established stands to withstand heavy grazing counterbalance this disadvantage.

\section{CANADA BLUEGRASS (Poa com-} pressa) forms a looser sod than Kentucky bluegrass; culms flat, wiry, foliage less abundant; panicles narrower and denser. Introduced into North America from Europe.

Distribution and habitat: Canada bluegrass commonly occurs in California at elevations of 6000 to $10,000 \mathrm{ft}$. Although unable to compete with other grasses on good soils, it is frequently abundant on clay soils of low fertility, occurring in pure dense stands on eroded areas where subsoil has been exposed. Chemical analysis and feeding tests indicate that Canada bluegrass, though nutritious, is of somewhat less food value than Kentucky bluegrass because it contains more crude fiber (10).

Forage value and reproduction: Young foliage of Canada bluegrass is relished by all classes of livestock, and is grazed to some extent by deer and elk. When kept closely grazed the seed stalks, which become fibrous and harsh when mature, remain palatable throughout the grazing season. Heavy grazing also promotes reproduction from rhizomes. Seed habits of Canada bluegrass are good. In fact, it is more promising for reseeding the poorer and drier sites than Kentucky bluegrass, even succeeding on gravelly and thin soils over rock or clay (43).

3. MUTTONGRASS (Poa fendleriana) is pale green with an abundance of short, rather stiff, slightly rough foliage at base, and narrow dense pale panicles. (Fig. 32.)

Distribution and habitat: Muttongrass, an important native bluegrass, also called Fendler bluegrass and mutton bluegrass, occurs in the Sierra Nevada in central California and in the San Ber-

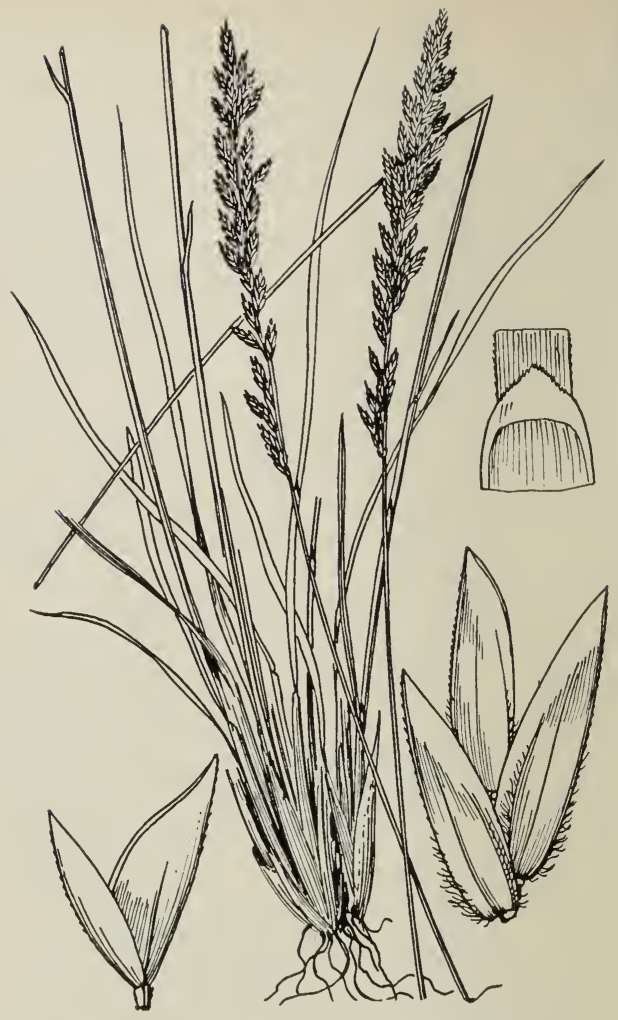

Fig. 32. Muttongrass (Poa fendleriana).

nardino Mountains in the south (2). It grows chiefly at higher elevations in open timbered areas and in well-drained parks and meadows. More drought-resistant than most bluegrasses, it also does well on drier, less fertile slopes where it frequently becomes abundant.

Forage value and reproduction: As growth begins early, muttongrass is ready for grazing in advance of most other range plants. Cattle and horses graze the immature foliage readily, and sheep eat considerable quantities of the basal leafage throughout the summer. In the Southwest it is regarded as one of the most nutritious forage plants, being prized for fattening sheep. Muttongrass produces a small seed crop of low viability, which probably accounts for its frequent failure in artificial range reseeding experiments (12). 
4. PINE BLUEGRASS (Poa scabrella) forms dense tufts as much as 4 in (10 $\mathrm{cm}$ ) across, with a mass of rather rough foliage at the base, mostly 4-7 in (10$18 \mathrm{~cm}$ ) high, the culms rather few to the tuft, reddish at the base, mostly $11 / 2$ to $21 / 2 \mathrm{ft}(45-75 \mathrm{~cm})$ tall; panicle narrow but loose; the spikelets not so flat as in most bluegrasses. (Fig. 33.)

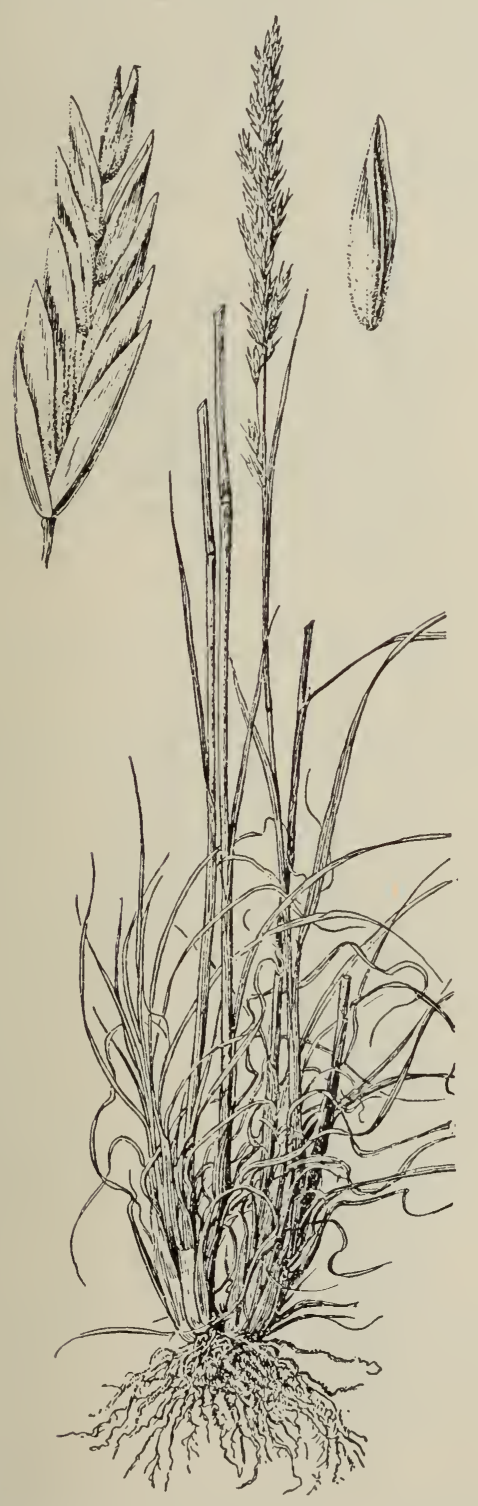

Fig. 33. Pine bluegrass (Poa scabrella).
Distribution and habitat: Pine bluegrass, widely distributed throughout California, occurs from near sea level on the coast to 9000 feet. It is most abundant in the upper ponderosa pine-sugar pine belt and in the Douglas fir forest (Transition and Canadian life zones), but is also important on ranges of low eleva tion in the coastal counties. It grows in open ground on gravelly or thin soils, and rocky outcrops, where it is one of the drought-enduring plants.

Forage value and reproduction: Pine bluegrass starts growth in December or January if moisture conditions are favorable on the foothill ranges. Protein and mineral contents of the young plants are high in this early growth stage (13). By the time of flowering two months later. however, the levels of both protein and minerals have dropped off considerably. In fact at seed maturity-just three months from the start of growth-the percentage of protein in pine bluegrass is below the minimum necessary to keep range animals in a thrifty condition.

Foraging animals relish the basal leafage of the grass, which is always grazed closely until after seed maturity. On summer ranges the fine, tender herbage is eagerly sought by lambs. Seed habits are moderately strong. At lower elevations seed ripens in May, but it is September before it is cast at higher altitudes.

\section{OLNEY BLUEGRASS (Poa nervosa) re-} sembles Kentucky bluegrass, but the foliage is paler and shorter; panicles more open; florets without cottony tuft at the base. An exceedingly variable species, its forms known under different names. A luxuriant form with rather rough leaves has been called Poa olneyae (described from Washington specimens).

Distribution and habitat: Olney bluegrass grows over a wide elevational range. It is most common on alpine meadows, open woods and grassy hillocks in the Sierra Nevada and high mountains in southern California. A comparatively 
drought-enduring species, it thrives on rather poor as well as on fertile soils. In many localities it is abundant and often forms the dominant vegetation, competing favorably with other herbs, especially non-turf-formers.

Forage value and reproduction: Olney bluegrass ranks high as forage. The palatable herbage and the ability to withstand heavy grazing combine to make it a valuable range grass. The leafy growth is relished by all stock and remains green throughout the summer. The seed, usually abundant and viable, matures about August or September. Young seedlings are vigorous and produce some forage the second year.

6. SKYLINE BLUEGRASS (Poa epilis) is erect from small to dense tufts; culms flat, 8-15 in $(20-40 \mathrm{~cm})$ tall; blades of basal tuft folded or involute, those of the culm flat, $2-3 \mathrm{~mm}$ wide; panicle narrow, 2-6 cm long; spikelets about $5 \mathrm{~mm}$ long; lemmas scaberulous.

7. PRINGLE BLUEGRASS (Poa pringlei) is densely tufted, 4-8 in $(10-20 \mathrm{~cm})$ tall, with a mass of short foliage at base, and narrow pale or silvery panicles, the spikelets about $6-8 \mathrm{~mm}$ long.

8. HANSEN BLUEGRASS (Poa hanseni) is related to the preceding, taller (15$30 \mathrm{~cm}$ ) and with longer, finer blades; panicles purplish, the spikelets smaller.

\section{PACIFIC BLUEGRASS (Poa gracillima)} forms large rather loose tufts, $1-2 \mathrm{ft}$ (30-60 cm) tall; panicles loose, 5-10 cm long, the branches few to several in whorls; spikelets $4-6 \mathrm{~mm}$ long.

These four species all occur at high altitudes in the Sierra Nevada in association with Suksdorf brome, nodding and bulbous melic grasses, and greenleaf fescue. They are similar to pine bluegrass in forage value but not in forage production, since they are not widely distributed and produce only a limited amount of seed.
10. NEVADA BLUEGRASS (Poa nevadensis) is rather coarse, grayish green, densely tufted, the blades long, narrow, inrolled, scabrous; panicles pale, narrow, somewhat interrupted; spikelets 6$8 \mathrm{~mm}$ long. (Fig. 34.)

Distribution and habitat: Nevada bluegrass occurs in the northeastern part of the state, where it grows at altitudes of from 4500 to $9000 \mathrm{ft}$. Though seldom abundant it is plentiful enough to furnish considerable forage throughout its range. It is a meadow species that grows luxuriantly on rich moist soils. Range stands are sometimes cut for hay. On the dry

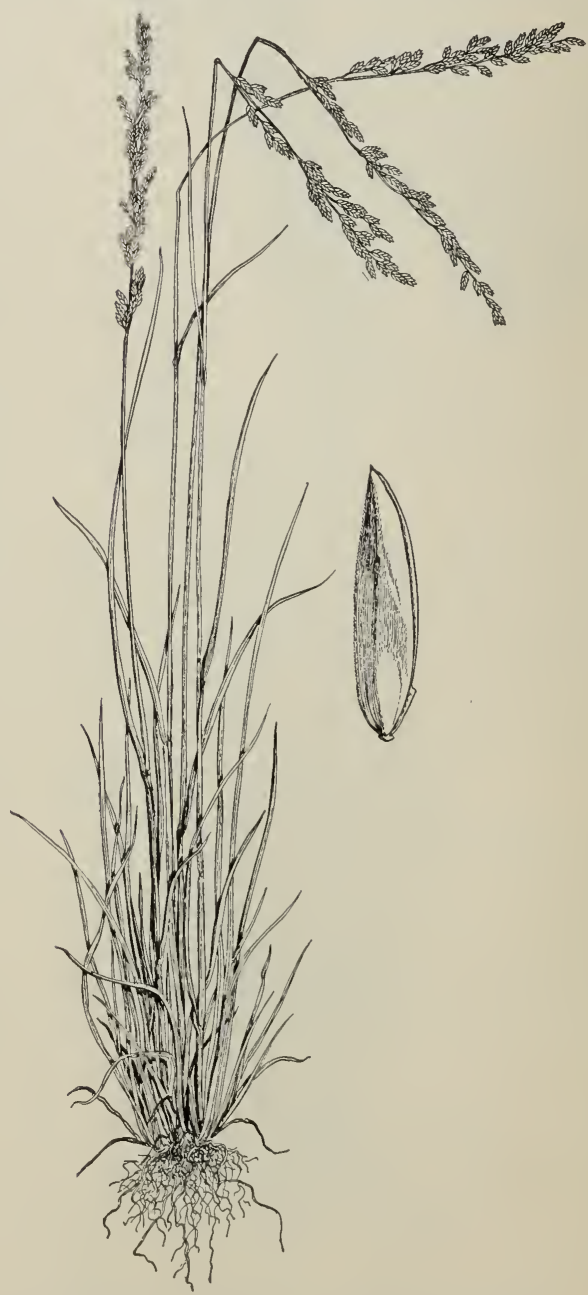

Fig. 34. Nevada bluegrass (Poa nevadensis). 


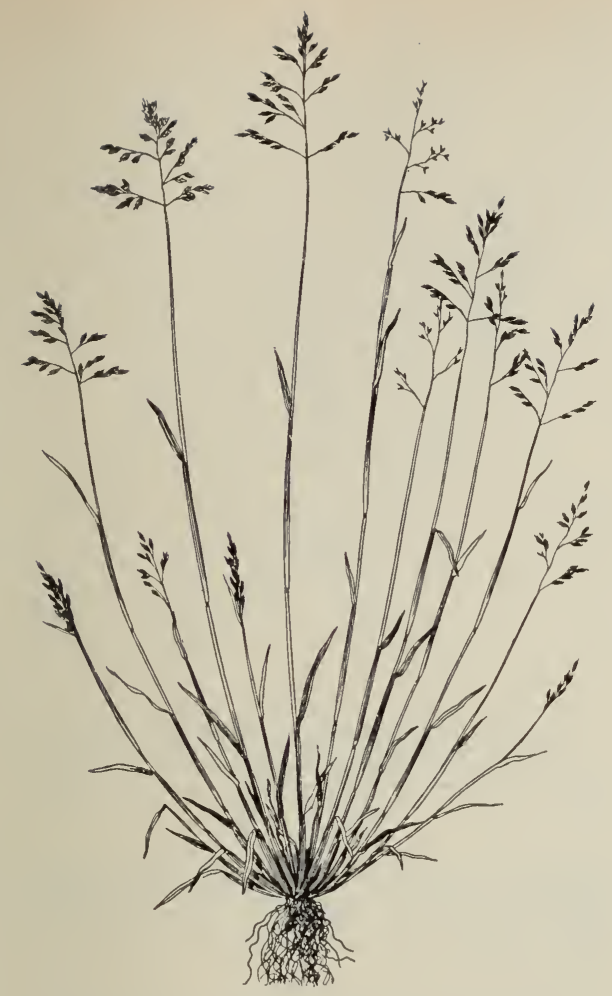

Fig. 35. Annual bluegrass (Poa annua).

meadows it commonly occurs in association with big sagebrush.

Forage value and reproduction: $\mathrm{Ne}$ vada bluegrass is leafier, stays green longer, and is more palatable than pine bluegrass but is not so widely distributed. Palatability is lowered at maturity, when the stalks and leaves become slightly tough. Seed habits are good, a large amount of seed of fair viability maturing from July to September. When deferred grazing is practiced, stands of Nevada seed and reproduce satisfactorily.

\section{Annual Bluegrasses}

11. ANNUAL BLUEGRASS (Poa annua) is a densely tufted winter annual, 6-10 in $(15-20 \mathrm{~cm})$ tall, sometimes taller, with soft bright green foliage and small pyramidal panicles. (Fig. 35.)

Distribution and habitat: Annual bluegrass is the most important of the four annual species. This low-growing winter annual ranges from sea level to timberline, growing on practically any nonacid soil where moisture is ample. Although not found on the desert, it appears seasonally with nearly all other plant associations, yet normally makes up but a small part of the total forage.

Forage value and reproduction: Annual bluegrass is readily grazed by stock during its period of succulence. Because of the low growth, sheep utilize the herbage to greater advantage than cattle. As in most annuals, the seed habits are strong. The seed crop matures from April to June in the foothills and in late summer in the mountains.

\section{SALTGRASSES (DISTICHLIS)}

Saltgrasses are grayish green perennials with strong extensively creeping rhizomes and wiry culms with numerous short stiff spreading blades and narrow panicles of rather long smooth spikelets. The staminate and pistillate spikelets are borne on separate plants. Flowering culms are sparsely produced in extensive areas of leafy plants.

Saltgrasses grow in saline soils and range from sea level to $6500 \mathrm{ft}$. Desert saltgrass, which occurs in the interior valleys, and saltgrass, which grows along the coast, are the two species of the genus in California. Although not particularly palatable, saltgrasses furnish considerable forage on alkaline range lands. When the stand is closely grazed, cattle take the young shoots. The herbage is not relished by sheep at any time.

\section{Key to Species}

Panicles condensed, the spikelets imbricate; keels of pistillate paleas with narrow entire wings

2. D. spicata

Panicles looser, the spikelets scarcely imbricate, the individual spikelets plainly visible; keels of pistillate paleas with broader serrate-erose wings

1. D. stricta 
1. DESERT SALTGRASS (Distichlis stricta) is 6-15 in (15-40 cm) tall, the panicle of long narrow spikelets often yellowish. (Fig. 36.)

Distribution and habitat: Desert saltgrass occurs in the interior valleys and deserts and on alkaline lands at higher elevations. This species is more widely distributed on California range lands than saltgrass and supplies an important part of the forage crop in the valleys, where it is commonly associated with alkali sacaton. (Fig. 37.) In northeastern California desert saltgrass is important in the succession of old lake beds. For example, in the dry part of Goose Lake it occupies the perimeter of alkali soils dominated by Pahute weed (Suaeda depressa), a species which is cut for hay during shortages of range and meadow feeds (50).

Forage value and reproduction: Where desert saltgrass is kept from becoming too rank by close grazing or mowing, cattle crop the young growth rather

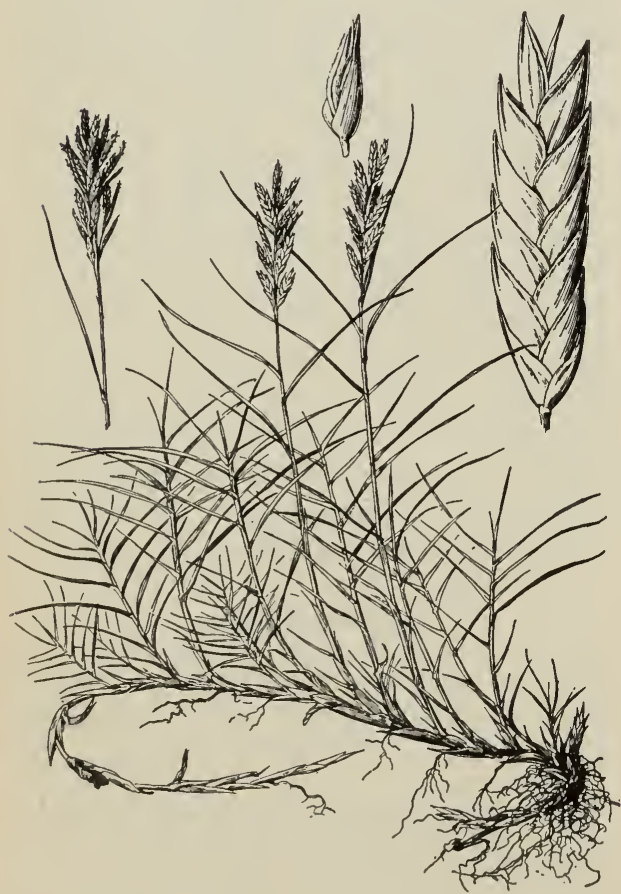

Fig. 36. Desert saltgrass (Distichlis stricta).

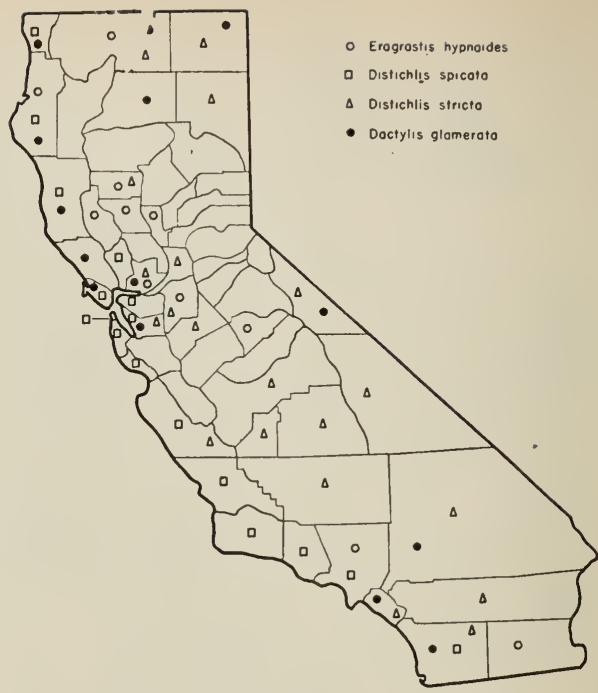

Fig. 37. Distribution of creeping lovegrass (Eragrostis hypnoides), saltgrasses (Distichlis spp.), and orchardgrass (Dactylis glomerata).

closely. They also graze the foliage when other sources of forage have dried or matured.

2. SALTGRASS (Distichlis spicata) is 10 to 30 , sometimes 40 , cm tall, mostly somewhat stouter than desert saltgrass; panicle pale or greenish.

The forage value of saltgrass is similar to that of desert saltgrass.

\section{MELICGRASSES (MELICA)}

Melicgrasses are loosely or rather densely tufted perennials, several species having swollen or bulb-like bases; panicles open or narrow, of mostly relatively large showy spikelets of $1-5$ fertile florets and 1-2 reduced sterile florets above.

Of the 13 species of melicgrasses in California, only eight are important forage plants. All are perennials of wide distribution but seldom occur in pure stands. (Figs. 38, 39.)

Melicgrasses range from sea level to $10,000 \mathrm{ft}$. They usually inhabit the summer ranges, being found in mountain meadows, parks, timbered areas, and brushlands. Comparatively early in the 


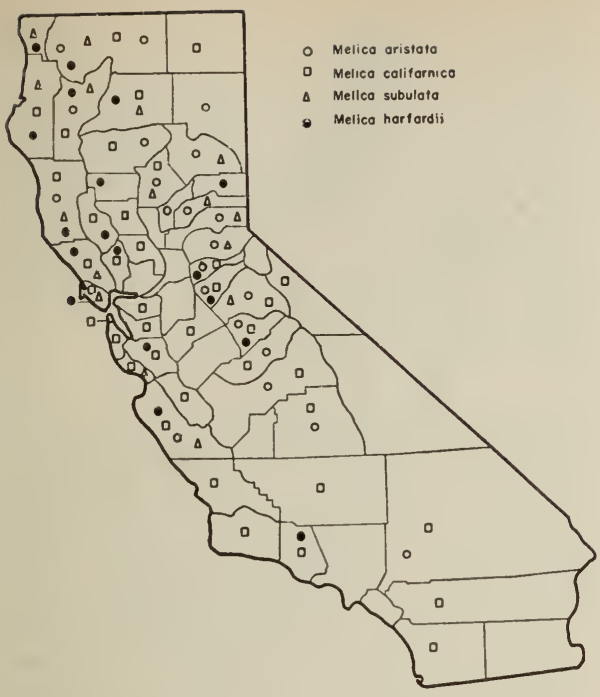

Fig. 38. Distribution of melicgrasses (Melica spp.).

course of plant succession, melicgrasses are frequently found in mixed grassweed types. They are commonly associated with bromegrasses, wheatgrasses, sedges, pentstemons, mountain dandelions, and bluebells (10). They prefer moist, fertile soils, but some species do well on the drier thinner soils of hillsides.

The melicgrasses are not of prime importance in beef and mutton production. Although moderately palatable, they do not make a dense growth except in restricted areas. Because of the sparse stand and scant foliage of most species, the melics must be classed as "fillers," that is, as food second in importance to more abundant (not necessarily more palatable) grasses.

Melicgrasses are grazed by all classes of livestock and to some extent by elk. Cattle and horses relish the foliage at all growth stages, and are especially fond of the flower stalks and seed heads. Sheep prefer the tender leafage early in the season, but return to graze it again in late fall. Individual plants produce a relatively large quantity of fertile seed.

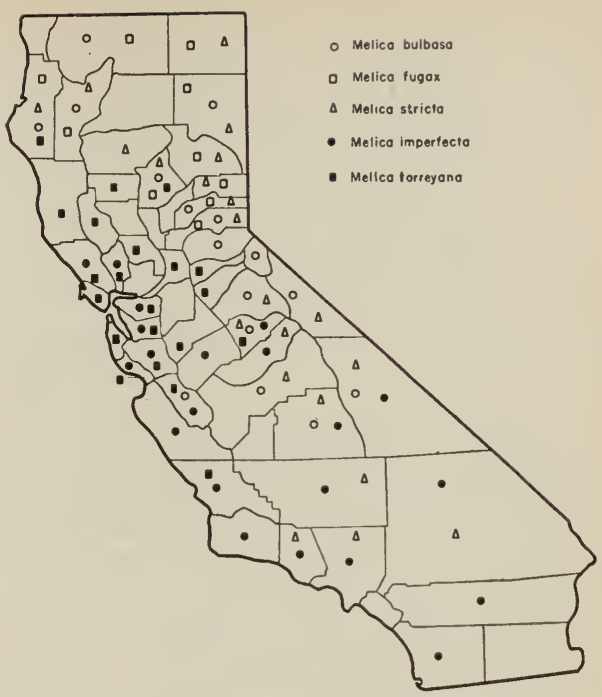

Fig. 39. Distribution of melicgrasses (Melica spp.).

Grazing after seed maturity tramples the seed crop into the soil and hastens revegetation of melicgrass stands. The most important range species in California are: awned melicgrass, California melicgrass, Alaska melicgrass, small melicgrass, bulbous melicgrass, purple melicgrass, nodding melicgrass, and smallflowered melicgrass.

\section{Key to Species}

Spikelets narrow, lemmas acuminate or awned; culms not bulbous at base

Lemmas awned or mucronate

Awn 6-10 mm long

1. M. aristata

Awn 1-2 mm long

3. M. harfordii

Lemmas acuminate, awnless 7. M. subulata

Spikelets broad; lemmas obtuse, awnless

Spikelets nodding on capillary pedicels

8. M. stricta

Spikelets not nodding; pedicels not capillary

Spikelets about $4 \mathrm{~mm}$ long with 1 or 2 fertile lemmas

Fertile floret glabrous, usually only 1

2. M. imperfecta

Fertile floret pubescent, usually 2

9. M. torreyana

Spikelets at least $7 \mathrm{~mm}$ long, mostly longer; fertile lemmas 2 or more 
Culms bulblike or swollen at base

Culms 8-16 in $(20-40 \mathrm{~cm})$ tall, rarely taller, in loose tufts with few to several bulblike bases attached; panicle branches spreading

6. M. fugax

Culms taller, the "bulbs" less swollen, less prominent; panicle narrow, the branches appressed

5. M. bulbosa

Culms not bulblike at base, but slightly swollen

4. M. californica

1. AWNED MELICGRASS (Melica aristata) is densely tufted, the slender culms $2-3 \frac{1}{4} \mathrm{ft}(60-100 \mathrm{~cm})$ tall, leafy; panicles narrow; spikelets narrow; lemmas with a slender awn. (Fig. 40.)

Distribution and habitat: Awned melicgrass is found in the Sierra Nevada from northern California south to Tulare County. The range in elevation is from 2500 to $7500 \mathrm{ft}$, where it grows in dry woods, grassy slopes, and medium moist meadows.

Forage value and reproduction: In

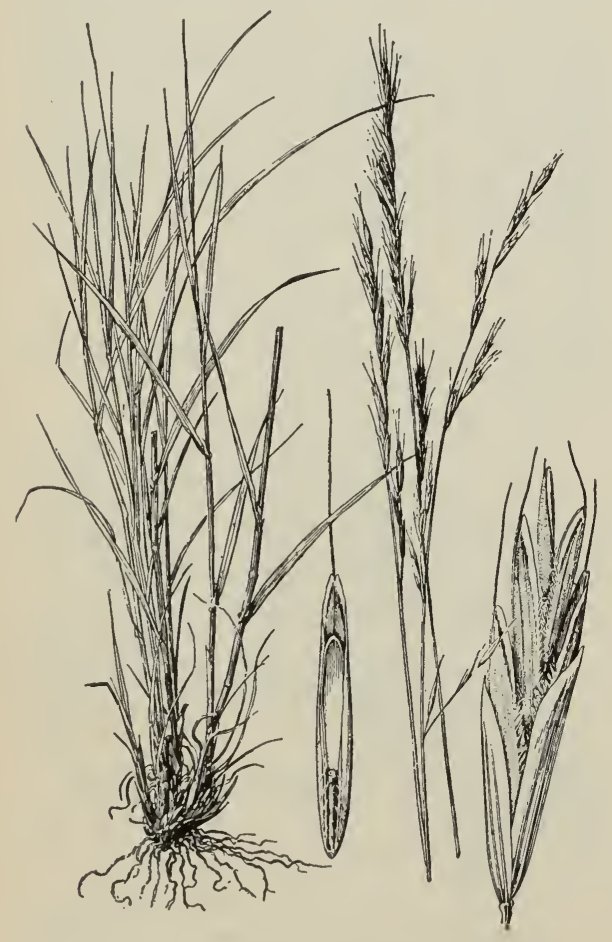

Fig. 40. Awned melicgrass (Melica aristata). spite of the awns, which are not particularly conspicuous, awned melic is grazed with relish by all classes of stock. At the time of seed maturity, however, the herbage becomes somewhat unpalatable to sheep. The flower stalks appear in May and June and the seed ripens in July and August. The amount of seed produced to a plant is small.

2. SMALL-FLOWERED MELICGRASS ( $\mathrm{Mel}$ ica imperfecta) is commonly $11 / 2-3 \mathrm{ft}$ $(45-90 \mathrm{~cm})$ tall in rather large tufts with abundant foliage, the lower sheaths brown, thin and papery; panicle 6-10 in $(15-30 \mathrm{~cm})$ long, the branches ascending or spreading, mostly in distant fascicles; spikelets about $4 \mathrm{~mm}$ long (smaller than in any other melic), purple-tinged. (Fig. 41.)

Distribution and habitat: Generally well distributed in California, smallflowered melic is found from sea level to about $6500 \mathrm{ft}$. The best stands occur in the foothill and low mountain lands, in pine woods, open chaparral, and on exposed hillsides. The plant is unusually tolerant of shade. In the coast ranges it grows on shallow, rather infertile soils, but rich moist or even seasonally wet lands are not adverse to its growth.

Forage value and reproduction:Smallflowered melic produces more choice forage than any other melic in the state. On the lower ranges growth begins with the autumn rains and continues through the winter and early spring. All classes of stock feed greedily upon the plant during this period, with the result that the stand is now waning seriously in many localities. In southern California the flower stalks begin to appear early in March and the seed ripens in May, but farther north flower-stalk production is delayed until May, and seed maturity up to late July. Seed habits are strong, a fairly large amount of seed being produced by strong healthy plants in favorable seasons. 


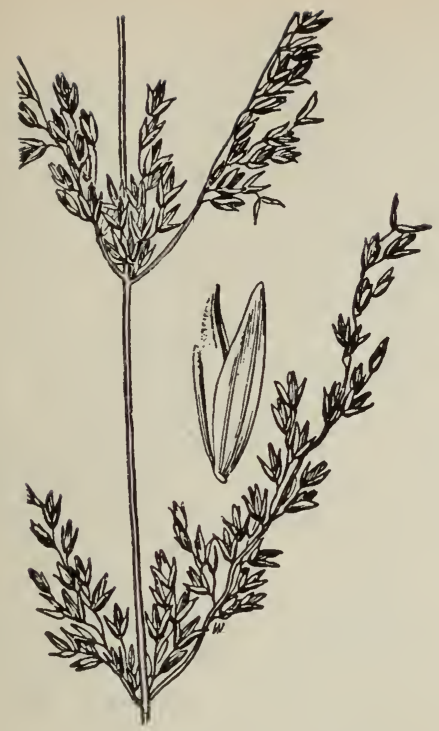

Fig. 41. Small-flowered melicgrass (Melica imperfecta).

3. HARFORD MELICGRASS (Melica harfordii) is densely tufted, mostly reddish and curved at base, 2-4. ft $(60-120 \mathrm{~cm})$ tall; blades elongate, scabrous; panicles slender; spikelets erect, purple, fading in age; lemmas pilose on the margin below, and with a minute awn from the obtuse apex.

Harford melicgrass occupies dryslopes and open woods at intermediate to low elevations from the northern part of the state to Ventura County. (Fig. 38.) Like other melics, this plant grows in scattered stands; and while it does not produce a large volume of forage it is taken with fair to good relish up to plant maturity, which varies from about June to August depending on locality.

4. CALIFORNIA MELICGRASS (Melica californica) is relatively robust, often 3 $\mathrm{ft}(90 \mathrm{~cm})$ or taller; lower sheaths persistent, brown and shredded; panicle narrow, mostly $6-8$ in $(15-20 \mathrm{~cm})$ long, tawny to purplish; spikelets shortpediceled, about 10-12 mm long.

Distribution and habitat: California melicgrass, a northern species, occurs in the northern coast ranges and at low to middle elevations in the Sierra Nevada (2). It ranges from sea level to about $5000 \mathrm{ft}$, occupying dry sites and ledges which are largely inaccessible to livestock.

Forage value and reproduction: Forage value of California melic is fair. Cattle graze it season long, but sheep and goats take only the succulent growth. The flower stalks appear in May and continue to be produced until early June. A fairly large seed crop reaches maturity in August. Judging from the abundance of California melic on protected areas, reestablishment of this plant should be possible under good grazing management.

5. BULBOUS MELICGRASS (Melica bulbosa) grows in dense clumps, the culms mostly 1-2 ft $(30-60 \mathrm{~cm})$ tall, the bases bulblike or sometimes only slightly swollen; panicles narrow, rather dense, the branches short, appressed; spikelets mostly 8-15 mm long.

Distribution and habitat: Bulbous melicgrass is most widely distributed on the eastern slope of the Sierra Nevada, occurring from Shasta County south to Tulare County. It occupies the drier sites in the intermountain region where it is known as Rocky Mountain melic grass.

Forage value and reproduction: $\mathrm{Al}$ though moderately relished by livestock, bulbous melic is not tall enough to be a heavy forage producer. However, the tender leafage is more acceptable to sheep than the coarser foliage of other melicgrasses. Seed habits of these two species are similar to those of Alaska melic.

\section{SMALL MELICGRASS (Melica fugax)} grows in loose tufts with numerous "bulbs" (short swollen internodes) at base; foliage pubescent; panicles 3-6 in $(8-15 \mathrm{~cm})$ long, at first narrow but the short branches spreading towards maturity; spikelets 8-14 $\mathrm{mm}$ long. (Fig. 42.) 


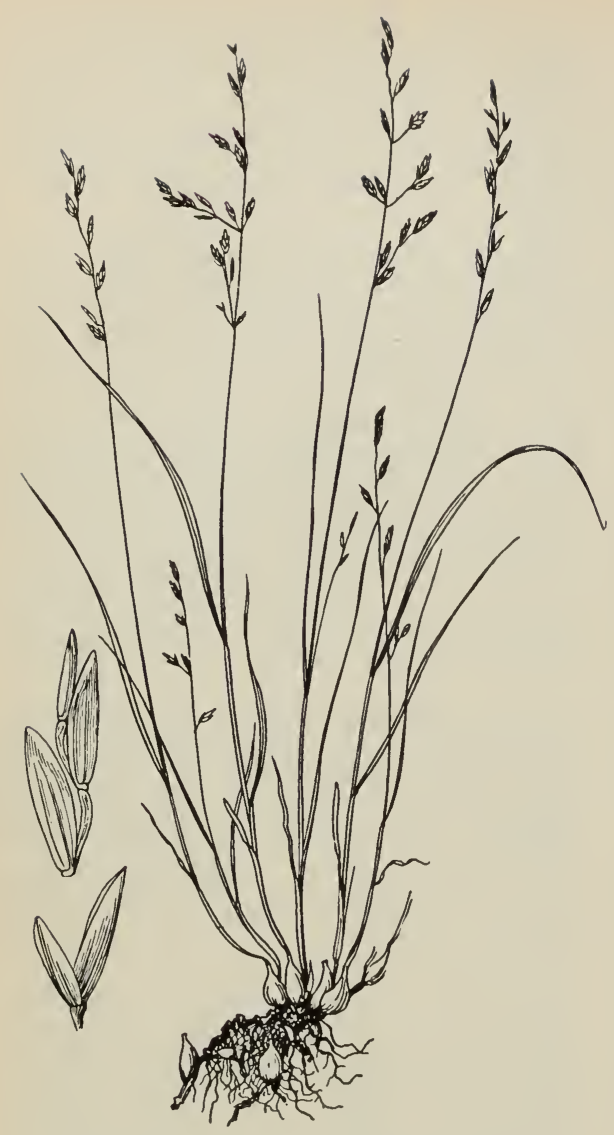

Fig. 42. Small melicgrass (Melica fugax).

Small melicgrass occurs in northeastern California on dry slopes above $5000 \mathrm{ft}$. It is most common in the ponderosa pine and juniper associations, where it occupies dry hillsides and open areas. The herbage of small melicgrass is of fairly high rank for cattle and horses, and good to fair for sheep. It is cropped rather closely throughout the grazing season. Reproduction is good where the range is grazed conservatively. The seed crop reaches maturity late in August.

7. ALASKA MELICGRASS (Melica subulata) is slender, usually about $31 / 4 \mathrm{ft}$ $(100 \mathrm{~cm})$ tall, the base somewhat bulblike; panicle 6-8 in (15-20 cm) long, narrow, or one or two of the short branches spreading; spikelets $1.5-2 \mathrm{~cm}$ long; loosely flowered.

Distribution and habitat: Alaska melic, another northern species, is found only in the northern part of the state, where it occurs from sea level to $7000 \mathrm{ft}$. Shady slopes, meadows, and semiwet areas are typical habitats.

Forage value and reproduction: Although palatable to all classes of stock, the scanty leafage places Alaska melic among the less valuable forage species of this genus. A seed crop of fair size is usually ripened and disseminated by early August.

8. NODDING MELICGRASS (Melica stricta) is densly tufted, purple at base, the culms $8-24$ in $(20-60 \mathrm{~cm})$ tall, leafy; panicle 3-6 in $(8-15 \mathrm{~cm})$ long, narrow, simple, the large handsome purple or pearly loosely flowered spikelets nodding on short capillary pedicels, falling entire. (Fig. 43.)

Nodding melicgrass is found in the extreme northern part of the state and at higher elevations in the Sierra Nevada south to Tulare County. Open ponderosa pine forests support the best stands. Though growing on rocky ledges and knolls, it responds to favorable environment, as indicated by the luxuriant stands along stream banks. Cattle relish the plant throughout the normal grazing season, whereas sheep graze the leafage closely only during the season of growth.

9. TORREY MELICGRASS (Melica torreyana) is loosely tufted, ascending from a decumbent base, $12-38$ in $(30-100 \mathrm{~cm})$ tall, mostly weak; blades lax; panicle $3-8$ in $(8-20 \mathrm{~cm})$ long, narrow, the slender branches loosely ascending; spikelets purplish, 4-6 mm long.

Distribution and habitat: Torrey melicgrass is essentially confined to the northern half of the state (fig. 39), where it occupies thickets, stream banks, and less commonly open areas of moderately moist soils at low to intermediate elevations. 


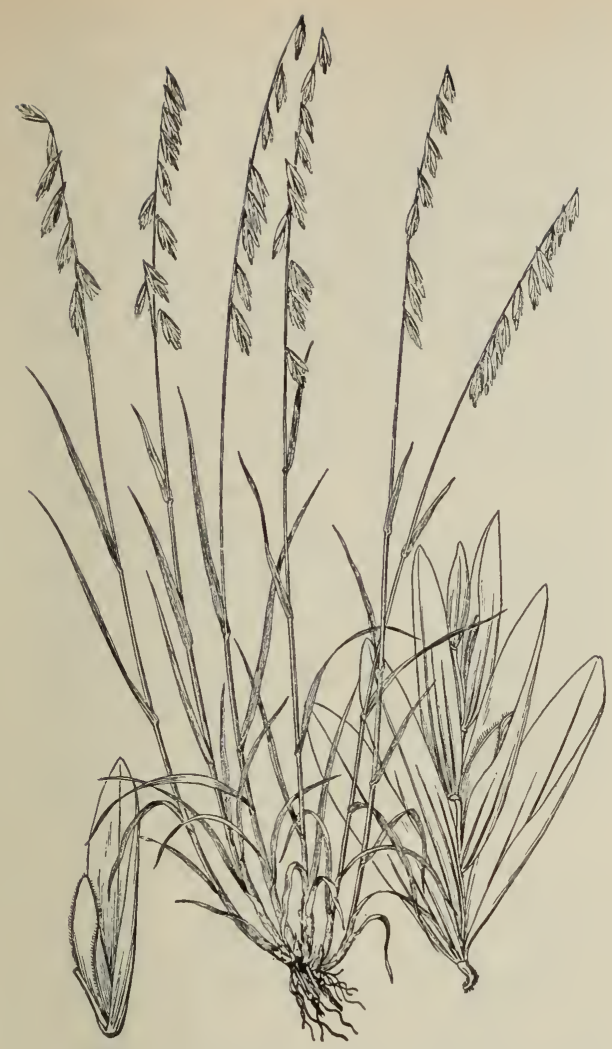

Fig. 43. Nodding melicgrass (Melica stricta).

Forage value and reproduction: The forage value of this grass is much the same as that of other melics, being palatable up to maturity to all stock. It grows in scattered stands and hence does not produce a large amount of seed.

\section{MANNAGRASS (GLYCERIA)}

Mannagrasses are mostly tall aquatic or marsh perennials with succulent culms, sometimes weak and readily falling; flat blades, and long panicles of severalflowered spikelets, the lemmas strongly parallel-nerved (appearing ridged), obtuse in our species.

Of the eight mannagrasses found in California, only two are widespread enough to be considered important for forage. (Fig. 44.) Although widely distributed, they are of limited local abun. dance. Sheep avoid wet ground and seldom graze upon mannagrasses, but cattle consume them more closely than the rushes (Juncus spp.) and sedges (Carex spp.) with which mannagrasses usually grow.

\section{Key to Species}

Spikelets ovate, 3-4 mm long; panicle open, drooping 1. G. elata

Spikelets linear, $1-1.5 \mathrm{~cm}$ long; panicle narrow, erect

2. G. borealis

1. TALL MANNAGRASS (Glyceria elata) grows in clumps, sometimes forming large tussocks, the leafy culms $2-3 \mathrm{ft}$ $(60-90 \mathrm{~cm})$ tall; panicles rather large, open, the branches drooping, with numerous small spikelets. (Fig. 45.)

Tall mannagrass is confined to moist or wet situations of medium elevation and is most abundant in the Sierra Nevada. (Fig. 44.) It is tolerant of shade and often forms an important part of the vegetation of marshy woodlands. The herbage of tall mannagrass is well liked by cattle, and is grazed by sheep late in the season when the site dries. The large crop of small seeds ripens in July and August.

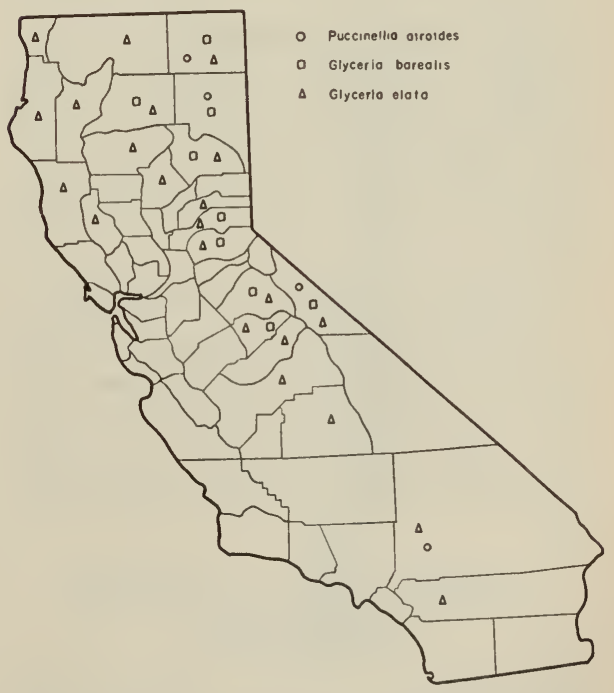

Fig. 44. Distribution of alkaligrass (Puccinellia airoides) and mannagrasses (Glyceria spp.). 


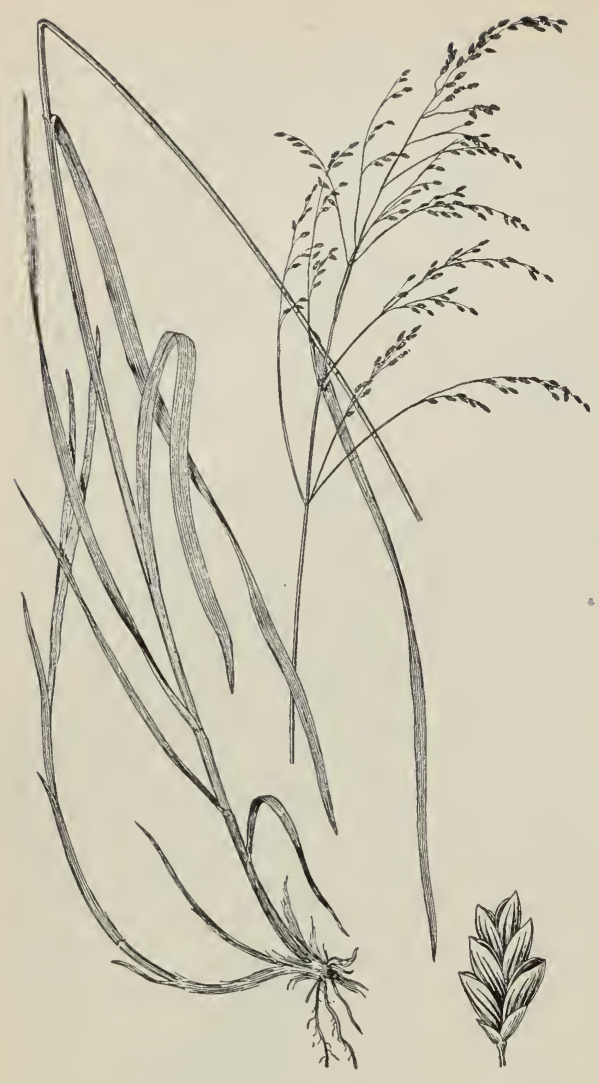

Fig. 45. Tall mannagrass (Glyceria 'elata).

2. NORTHERN MANNAGRASS (Glyceria borealis) is mostly subaquatic, weakstemmed, $2 \frac{1}{2}-3 \frac{1}{4} \mathrm{ft}(75-100 \mathrm{~cm})$ tall, with pale panicle $9-18$ in $(20-45 \mathrm{~cm})$ long, the narrow, pale spikelets appressed to the erect or ascending branches.

Northern mannagrass also is adapted to marshy sites. It is found in boggy areas on the margins of lakes, ponds, or rivers in northeastern California. (Fig. 44.) Northern mannagrass is seldom abundant enough to furnish much grazing.

\section{ORCHARDGRASS (DACTYLIS GLOMERATA)}

Orchardgrass is a tall coarse perennial growing in large tussocks; blades flat, elongate; panicles 10-20 cm long, of few stiffly spreading branches with densely clustered spikelets towards the ends; spikelets strongly compressed, the glumes and lemmas ciliate on the keel. Introduced from Eurasia. (Fig. 46.)

Distribution and habitat: Orchardgrass now grows naturally on many California range lands. (Fig. 37.) It is the only species in the genus in the United States, and has derived its name from its frequent occurrence in orchards. Being fairly tolerant of shade, it grows more in open woodlands than most meadow grasses. It occurs commonly in the north coastal region where it has been used successfully to reseed burns in loggedover redwood stands (51). It has been recommended for reseeding above 3000 $\mathrm{ft}$ in foothill and mountain ranges of northeastern California (36) .

Forage value and reproduction: Be-

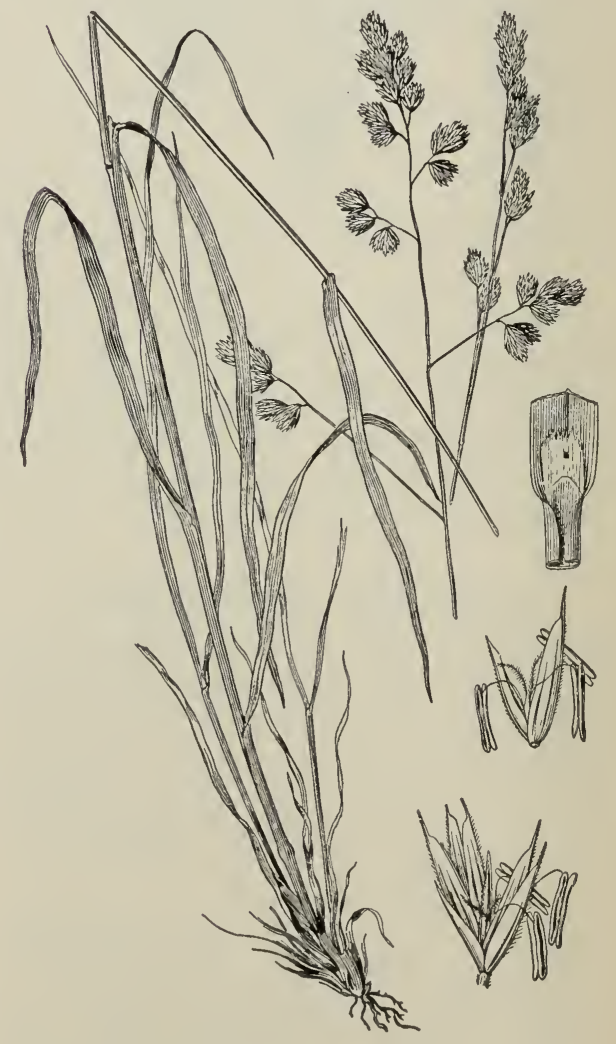

Fig. 46. Orchardgrass (Dactylis glomerata). 
fore flowering, orchardgrass is hardly surpassed in feeding value (8), and is readily taken by all livestock. It is also richer than most grasses in phosphorus and calcium (39). At maturity, however, it becomes woody and loses much of its nutritive content. Due to its early growth orchardgrass makes better pasturage when mixed with later maturing legumes and/or grasses. Although slow in getting established, orchardgrass is fairly drought resistant and does well in almost any soil.

\section{LOVEGRASSES (ERAGROSTIS)}

The California species are annuals, mostly shallow-rooted and weedy, branching from the base, and with scant foliage; panicles open, the small glabrous spikelets several-flowered. There are nine species in the state, three of them introduced weeds.

Though occurring over a wide range in California ranges, the lovegrasses furnish but little forage. They are somewhat palatable, but not abundant enough to contribute appreciably to the forage crop. Creeping lovegrass is the most common and widely distributed species.

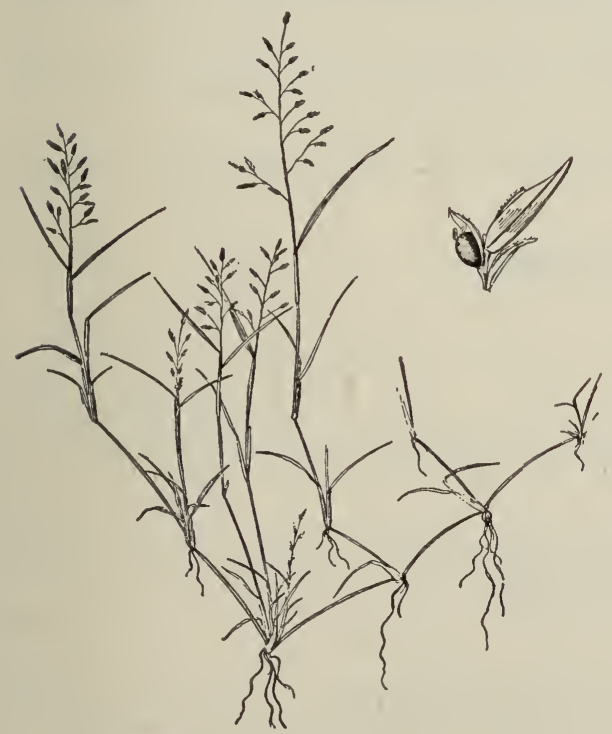

Fig. 47. Creeping lovegrass (Eragrostis hypnoides).
CREEPING LOVEGRASS (Eragrostis hypnoides) is low and slender, the culms widely creeping and sending up flowering branches, the whole sometimes extending several feet in favorable situations, the panicles open, $2-5 \mathrm{~cm}$ long; in dry places forming small dense mats, the panicles reduced, almost capitate. (Fig. 47.)

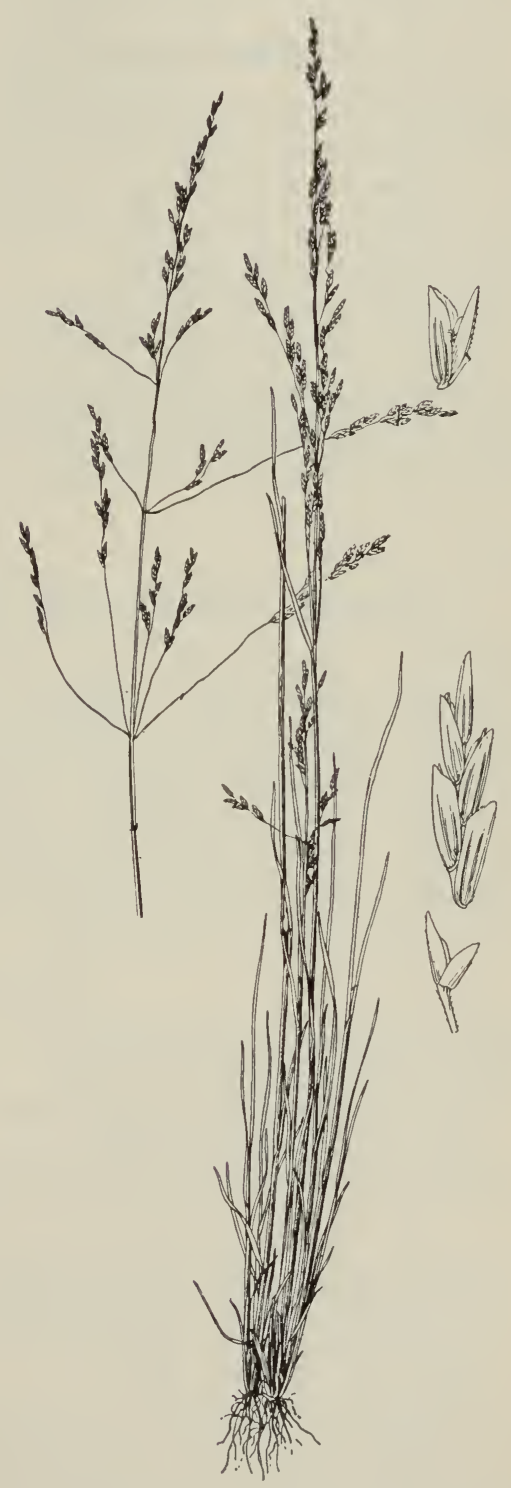

Fig. 48. Alkaligrass (Puccinellia airoides). 
Creeping lovegrass occurs at low elevations throughout the state, growing on damp sand bars in the northern coast ranges, and along sandy river banks in central and southern California. (Fig. 37.) Though palatable, the fine, prostrate plants do not furnish much grazing. Sheep utilize the herbage better than cattle. As in most annuals, a large seed crop matures early in the summer.

\section{ALKALIGRASS (PUCCINELLIA)}

Alkaligrasses are low, smooth-tufted annuals or perennials, with narrow blades, the panicles and spikelets resembling those of the bluegrasses, but the lemmas blunt and the nerves parallel.

Of the six species occurring in California only one, Nuttall alkaligrass, is important for forage. Alkaligrasses typically inhabit salt marshes or brackish areas along the coast, and alkaline val- leys or meadows of the interior. They are more palatable than most alkalienduring plants and produce good seed crops. (Fig. 44.)

NUTTALL ALKALIGRASS (Puccinellia airoides) is an erect, grayish, tufted perennial, mostly $1-2 \frac{1}{2} \mathrm{ft}(30-75 \mathrm{~cm})$ tall, with narrow rather short blades, open panicle, mostly $10-20 \mathrm{~cm}$ long, the small spikelets short-pediceled along the slender, ascending branches; lemmas fivenerved, obtuse. (Fig. 48.)

In California, alkaligrass is found only on the east slope of the Sierra Nevada and in the San Bernardino Mountains. It occupies moist alkaline meadows and furnishes considerable forage where common. The basal leafage of young plants is readily taken by livestock, and even the more mature herbage is grazed as aftermath when occurring in alfalfa stands cut for hay.

\section{WHEATGRASS AND BARLEYGRASS TRIBE (HORDEAE)}

Spikelets on opposite sides of a jointed or continuous rachis, forming 2-ranked spikes, the spikes solitary; spikelets (in species of forage value) rather large, the glumes persistent, the florets falling at maturity, or the rachis disjointing with 2-few spikelets persistent on each joint. The blades usually bear a small claw-like auricle on each side at the base. In Elymus condensatus and E. cinereus the spikes are usually compound, at least in part of the spike.

This small tribe includes our most important cereals, wheat, barley, and rye, and also several valuable forage grasses.

\section{KEY TO GENERA}

Spikelets single at each node of the rachis

Spikelets placed flatwise to the rachis

Plants perennial; spikelets compressed

10. Agropyron (p. 63)

Plants annual, spikelets cylindric

16. Aegilops (p. 73)

Spikelets placed edgewise to the rachis; first glume wanting except in the terminal spikelet

15. Lolium (p. 72)

Spikelets 2 or more at each node of the rachis

Glumes obsolete or reduced to short bristles; spikelets spreading at maturity 13. Hystrix (p. 69)

Glumes well developed; spikelets appressed or ascending

Rachis continuous (in our species)

11. Elymus (p. 65)

Rachis disjointing at maturity

Spikelets 2-3 flowered, 2 at each node of the rachis, both sessile

12. Sitanion (p. 68)

Spikelets 1-flowered, 3 at each node of the rachis, the lateral pair pediceled, their glumes usually reduced to awns, the floret reduced or rudimentary, rarely staminate

14. Hordeum (p. 70) 


\section{WHEATGRASSES (AGROPYRON)}

Wheatgrasses are mostly tall, firm-leaved, perennial bunch grasses with erect leafy culms and slender spikes; spikelets several-flowered, the glumes persistent, florets falling at maturity.

Eleven native wheatgrasses grow in California; only three-bearded wheatgrass, bluebunch wheatgrass, and slender wheatgrass-are of importance on the range. (Fig. 49.) Production of wheatgrasses on California ranges is small in comparison with other far western states. Good stands are restricted to the northeastern part of the state where they occur from 3000 to $10,000 \mathrm{ft}$. High in the successional stage of plant cover, wheatgrasses rank as excellent forage. They usually occupy fertile soils of rolling grassland or open timber stands, but are also found on drier slopes and benchlands in association with sagebrush and bitterbrush.

Wheatgrasses furnish nutritious forage throughout the grazing season. At lower elevations they are pastured in spring and fall, and in the mountains mainly during spring and summer. After seed maturity the stalks become too coarse

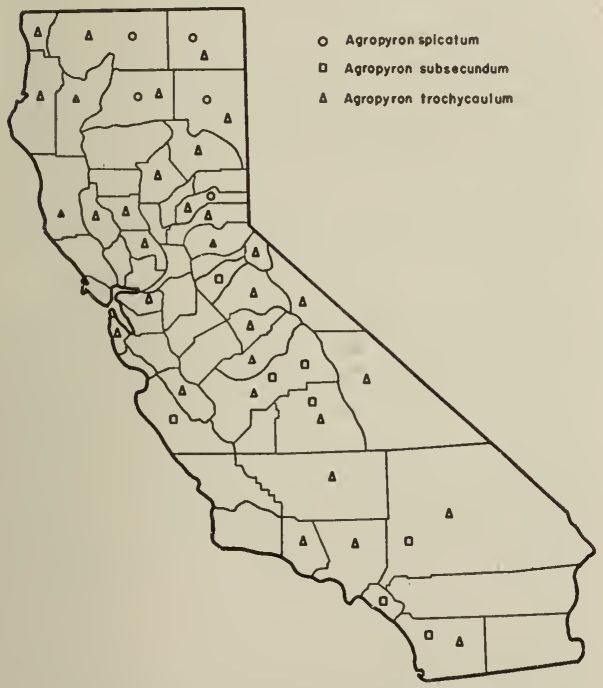

Fig. 49. Distribution of wheatgrasses (Agropyron spp.) and fibrous for sheep, but cattle readily eat the cured herbage and stalks. Both bearded and bluebunch wheatgrass depend on seed for reproduction. Vigorous plants produce large seed crops, and properly managed stands are adequately maintained.

\section{Key to Species}

Spikelets much compressed, crowded on the rachis, short-awned, the awn bent to one side.

Spikelets narrow, divergent from the rachis, glumes contorted

4. A. cristatum

Spikelets ascending to somewhat spreading; glumes not contorted

5. A. desertorum

Spikelets not compressed nor divergent

Lemmas awned

Awns straight, erect 3 . A. subsecundum

Awns bent, divergent

1. A. spicatum

Lemmas awnless

2. A. trachycaulum

\section{BLUEBUNCH WHEATGRASS (Agropy-}

ron spicatum) is $2-31 / 4 \mathrm{ft}(60-100 \mathrm{~cm})$ tall, often in very large tough clumps; blades $2-4 \mathrm{~mm}$ wide; spike slender, $31 / 2-6$ in $(8-15 \mathrm{~cm})$ long; spikelets rather distant; glumes usually about half as long as the spikelets; lemmas with divergent awns mostly $1-2 \mathrm{~cm}$ long.

Distribution and habitat: Bluebunch wheatgrass is most abundant in northeastern California where it occurs on lava soils at medium altitudes. It is fairly drought-resistant and does well on dry soils, especially those of good fertility. Although usually found on open, exposed slopes, it endures partial shade and is frequently associated with sagebrush. Close, repeated spring grazing, when herbage removal is most detrimental to the plant, has caused replacement of bluebunch wheatgrass by downy chess and sagebrush over a large part of the intermountain region (58).

Forage value and reproduction: Where abundant, bluebunch wheatgrass is a valuable forage plant. It is relished by all classes of stock, and is even grazed avidly late in the season, especially when fall rains stimulate new growth As compared to other range grasses, this 
grass has a relatively high late-season nutrient content, which probably accounts for its value as a winter feed. Seed production is good at medium elevations, but deferred grazing is needed to assure satisfactory reproduction of most stands.

2. SLENDER WHEATGRASS (Agropyron trachycaulum) resembles bearded wheatgrass, the spikes usually more slender, 4-10 in (10-25 cm) long, sometimes slightly twisted, appearing unilateral; spikelets mostly not overlapping; lem-

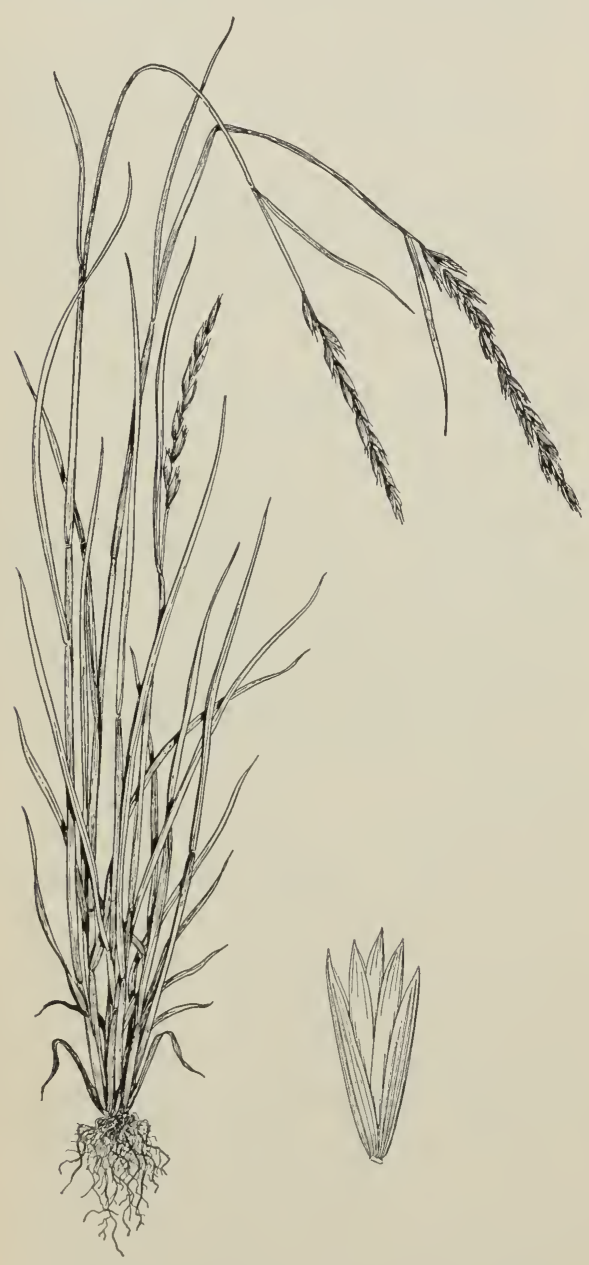

Fig. 50. Slender wheatgrass (Agropyron trachycaulum). mas awnless; glumes broad, nearly as long as the spikelet. (Fig. 50.)

Distribution and habitat: Slender wheatgrass is fairly abundant in northeastern California where it grows between 3000 and 10,000 ft. It is found in open woods, rocky exposed hillsides, upland plains, and on moist meadows.

Forage value and reproduction: The herbage of slender wheatgrass is choice feed for all grazing animals. Sheep graze the young herbage nearly as well as finer-leaved fescues and bluegrasses. Cattle and horses crop the foliage throughout the growing season. It is excellent winter feed and produces an abundance of seed. Although the grass has been used to some extent in artificial range reseeding, stands have been slow to establish.

3. BEARDED WHEATGRASS (Agropyron subsecundum) is mostly $2-31 / 4 \mathrm{ft}$ (60$100 \mathrm{~cm})$ tall, in large lumps; blades to 6-8 $\mathrm{mm}$ wide; spike $21 / 2-6$ in $(6-15 \mathrm{~cm})$ long; glumes broad, nearly as long as the spikelet; lemmas with straight awns mostly 1-2 cm long, sometimes shorter or longer. (Fig. 51.)

Distribution and habitat: Bearded wheatgrass occurs scatteringly in the mountains of central and northern California between 3500 and $9500 \mathrm{ft}$. Though typically inhabiting light soils of moist slopes and meadows, it is also found on dry hillsides and in partial shade of open timber or brush stands.

Forage value and reproduction: Bearded wheatgrass is highly palatable to all classes of livestock early in the season, when an abundance of basal leafage is produced. At seed maturity the awns make the forage less desirable, especially for sheep. This seasonal change in forage value is accompanied by a definite decline in the levels of essential nutrients. Early season foliage has a high nutrient content, but by September, when the plant is mature, levels of both crude protein and phosphorus 


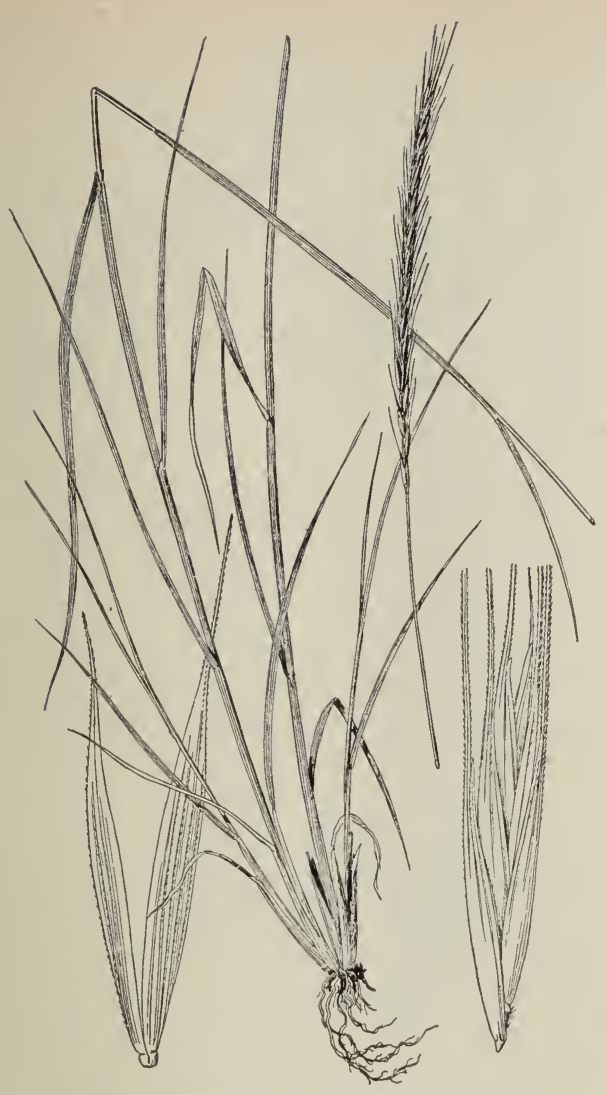

Fig. 51. Bearded wheatgrass (Agropyron subsecundum).

are often critically low (59). The fact that the awned seed heads are not readily grazed presumably favors reproduction.

4. CRESTED WHEATGRASS (Agropyron cristatum) has mostly shorter spikes with more widely spreading spikelets, the glumes somewhat contorted and with longer curved awns. Introduced from Russia.

This grass is sometimes mixed with desert wheatgrass. It is grown in experimental stations and is a valuable dryland grass.

5. DESERT WHEATGRASS (Agropyron desertorum) is densely tufted, 12-38 in $(30-100 \mathrm{~cm})$ tall, with dense spikes 2$3 \frac{1}{2}$ in $(5-9 \mathrm{~cm})$ long, the spikelets crowded and spreading; glumes and lemmas with short stiff commonly slightly bent awns. Introduced from Russia.

Formerly confused with crested wheatgrass, desert wheatgrass is now established on some range areas in the northeastern part of the state, and is beirg seeded by Forest Experiment Stations at intermediate elevations. It has sparingly escaped in Kern and Ventura counties.

\section{WILD-RYE GRASSES (ELYMUS)}

Wild-rye grasses are tall, mostly coarse perennials (one introduced annual), with leafy culms and slender to dense spikes; spikelets 2-6 flowered, 2-4 together at each node of a continuous rachis; glumes narrow, persistent, florets falling at maturity.

The 12 native wild-rye grasses in the state are perennials. Four species are valuable range grasses. An introduced annual has become a serious pest on many California ranges.

Wild-rye grasses are widely distributed in the state, occurring from near sea level in the valleys and along the coast to $10,000 \mathrm{ft}$ in the mountains. (Fig. 52.) They grow on a variety of sites, some

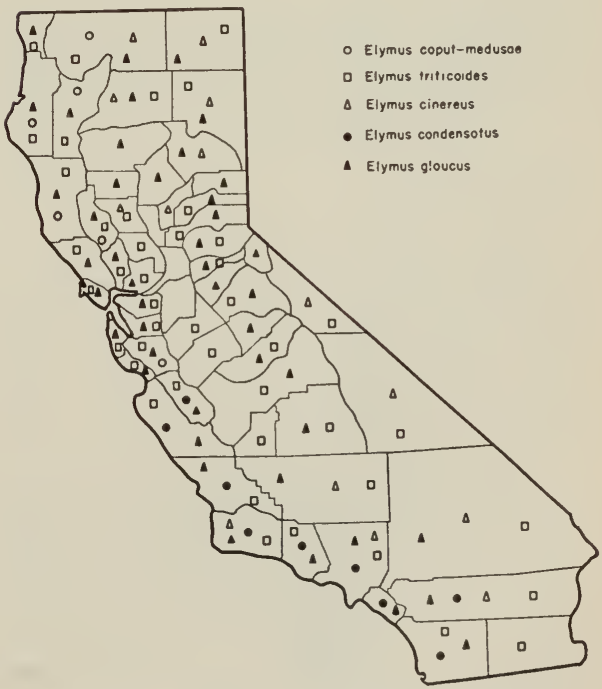

Fig. 52. Distribution of wild-rye grasses (Elymus spp.). 
species in moist valleys and meadows, others on dry hillsides and in open stands of brush and timber.

Wild-rye grasses are important forage plants. Although generally coarse and of low palatability when mature, they are sought by all kinds of livestock when green. The smaller, softer-leaved species are desirable food for most livestock during the growing season, whereas the larger, coarser bunch-formers furnish valuable winter forage. Most wild-ryes are strong seed producers, and two with poor seed habits (beardless and big wildrye) reproduce freely from rhizomes as well as by seed.

The most important perennials are: beardless wild-rye, ashy wild-rye, big wild-rye, and blue wild-rye.

\section{Key to Species}

\section{Plants perennial}

Rhizomes present

Spike slender, spikelets mostly in $2 \mathrm{~s}$; rhizomes slender, widely creeping

2. E. triticoides

Spike thick, mostly compound, with crowded short branches, spikelets in 3s$5 \mathrm{~s}$; rhizomes short, thick (commonly wanting in herbarium specimens)

3. E. condensatus

\section{Rhizomes wanting}

Lemmas awnless; spike dense, rarely compound, ashy

4. E. cinereus Lemmas awned; spike green, loose, spikelets not imbricate

Plants annual

1. E. glaucus

5. E. caput-medusae

1. BLUE WILD-RYE (Elymus glaucus) is a tufted leafy perennial, 2-4 $\mathrm{ft}(60-120$ cm) tall; foliage rather soft, the blades to $10-12 \mathrm{~mm}$ wide; spike erect to nodding, the spikelets with slender awns mostly $2-3.5 \mathrm{~cm}$ long. (Fig. 53. )

Distribution and habitat: Occurring throughout the state, blue wild-rye ranges from near sea level to $10,000 \mathrm{ft}$. It rarely forms pure stands, and grows on moderately moist woodlands but sometimes occupies dry hillsides where it withstands drought remarkably well.

Forage value and reproduction: In

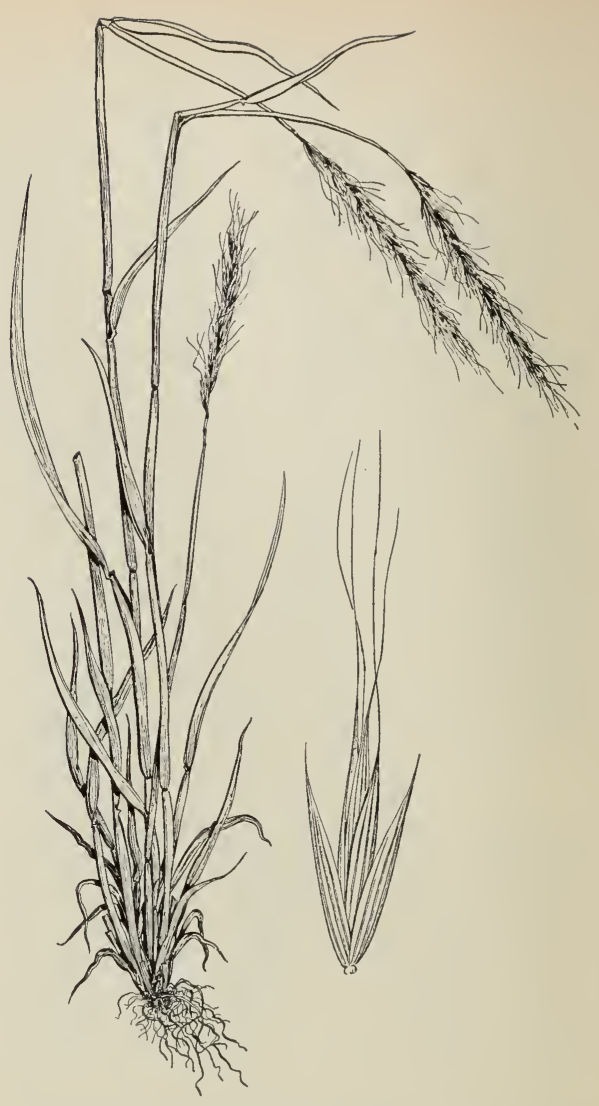

Fig. 53. Blue wild-rye (Elymus glaucus).

fertile areas where a dense growth of leafy foliage is produced, blue wild-rye is an important forage plant. It is eaten with relish by all livestock early in the season, but before long becomes too rank for sheep. An abundance of good seed is produced, ripening early in July in the foothills and late in August at higher altitudes. When deferred grazing is practiced, stands are measurably increased on winter ranges, where blue wild-rye is a valuable feed.

2. BEARDLESS WILD-RYE (Elymus triticoides) is a glaucous perennial with extensively creeping rhizomes, forming large colonies; culms $2-31 / 2 \mathrm{ft}(60-120$ $\mathrm{cm})$ tall; spike 4-6 in (10-15 cm) long, spikelets often purplish-tawny, some- 
times single at a node towards the summit, awnless.

Distribution and habitat: Beardless wild-rye, sometimes called alkali ryegrass, is adapted to moist bottomlands which are slightly brackish or alkaline, but is also found on mountain slopes and in open timber up to $10,000 \mathrm{ft}$. In irrigated sections or where water naturally collects, this species frequently forms pure stands.

Forage value and reproduction: Although the blades are too stiff and coarse to rank as superior forage, beardless wild-rye is grazed to an average degree by cattle and horses. At best it is only of secondary importance for forage. Adequate revegetation of stands is assured by heavy seed production and strong rhizomes.

\section{BIG WILD-RYE (Elymus condensatus)} is very robust, in large clumps with short thick rhizomes; culms usually $6-91 / 2 \mathrm{ft}$ (2-3 meters) tall; blades $1.5-3 \mathrm{~cm}$ wide; spike very dense, compound, 6-25 in (15-50 cm) long; spikelets commonly distorted by pressure; glumes and lemmas pointed.

Big wild-rye occurs along the coast in central and southern California, where it grows mostly on sand dunes, rocky slopes, and ravines. Rhizomes enhance the value of this species as a soil binder, and it is similar to ashy wild-rye in forage value and reproduction.

4. ASHY WILD-RYE (Elymus cinereus) is a robust bunchgrass; culms mostly $3 \mathrm{ft}$ $(90 \mathrm{~cm})$ or taller; foliage glabrous to harsh-puberulent, the blades 10-15 mm wide, coarse; spike mostly 10-20 cm long, thick dense, tawny; spikelets crowded, awnless.

Distribution and habitat: Formerly included with big wild-rye, ashy wild-rye grows on moist or dry slopes, along river banks, and in dry, rich soils, mostly at middle altitudes. Stands in northern California are found principally on the east slope of the Sierra Nevada; in the southern part of the state, they extend westward into the interior desert areas of Santa Barbara and Los Angeles counties.

Forage value and reproduction: $\mathrm{Be}$ cause of its coarse, rank habit ashy wildrye rates as rather inferior forage. Except for a short period in early spring the foliage is unusually harsh and tough. The leafage is not utilized as summer forage if more palatable feed is available. Cattle and horses, however, feed upon it after the herbage is softened by winter rains. Continued early-spring grazing has greatly reduced, or, indeed, sometimes all but eliminated, extensive stands of ashy wild-rye, formerly an important source of winter feed. Seed production is good, but careful grazing in early spring is necessary to allow establishment of the palatable young seedlings.

\section{MEDUSA-HEAD (Elymus caput-medu-} sae) is a slender weedy annual, 8-24 in $(20-60 \mathrm{~cm})$ tall, with scant foliage and short broad spikes; lemmas with slender spreading awns $5-10 \mathrm{~cm}$ long. Introduced from Europe. (Fig. 54.)

Distribution and habitat: Medusahead is rapidly spreading on ranges in the northern coastal counties southward to Solano County. Recently it has been reported in Placer County where it is ex-

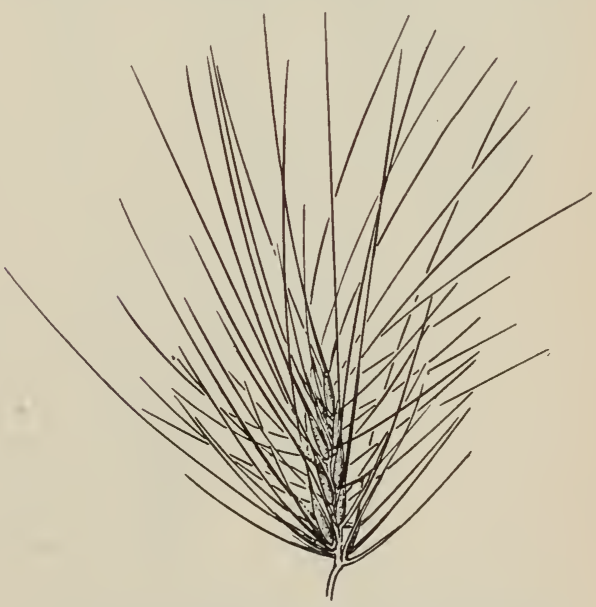

Fig. 54. Medusa-head (Elymus caput-medusae). 
tending its hold (45), especially on overgrazed ranges. It is found on open areas at low to medium altitudes.

Forage value and reproduction: Although medusa-head matures late, it is taken little or not at all by livestock at any growth stage. Its heavy seed production, characteristic of most annual grasses, contributes to its aggressiveness; on many ranges it occurs to the near exclusion of more valuable forage grasses.

\section{SQUIRRELTAILS (SITANION)}

Squirreltail grasses are relatively short, densely tufted perennials with very bristly spikes, the axis disjointing at the base of each segment, this remaining as a pointed stipe below the attached longawned spikelets. The three species of the U. S. are extremely variable and have received several names.

All three squirreltails are represented on California range lands. They are native bunchgrasses chiefly confined to dry, rocky, or semidesert plains, but also occur less abundantly in open woodlands at higher elevations. (Fig. 55.)

Squirreltails, before the heads develop, rank as fair to good forage for cattle,

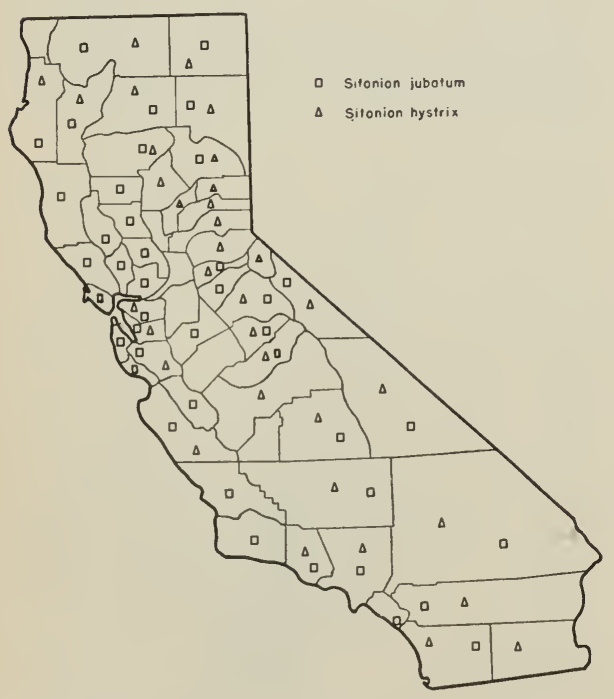

Fig. 55. Distribution of squirreltail grasses (Sitanion spp.). horses, and sheep. However, from their earliest appearance the bristly spikes are objectionable to livestock, and mature plants are seldom closely grazed, at least until the seeds have scattered, or autumn rains have softened the awns. Where squirreltails are abundant, the disjointed spikes work into the eyes, nose and mouth of grazing animals, causing much annoyance. On the whole, the plants are regarded as inferior after seed formation. Seed production is abundant; careful management is necessary to encourage more palatable species on squirreltailinfested ranges.

\section{Key to Species}

Spike much longer than broad Spike as broad as long, or broader

Glumes entire or 2-cleft

3. S. hanseni

Glumes cleft into at least 3 fine divisions

2. S. jubatum

1. SQUIRRELTAIL (Sitanion hystrix) has stiff erect to spreading culms 4-18 in (10-45 cm) tall, blades firm; spike 2-7 $\mathrm{cm}$ long, rarely longer; glumes sometimes split to the middle or with a bristle on one margin; awns of glumes and lemmas 2-10 cm long. (Fig. 56.)

Distribution and habitat: Squirreltail, also called bottlebrush squirreltail, is the most abundant species of the genus. It occurs in scattered stands mostly at high elevations, on dry, gravelly soils, or in saline situations. It also grows fairly commonly on hillsides and on alkaline flats in weed, grass, and brush associations (10).

Forage value: Palatability of squirreltail varies according to the season of the year. It is generally fair to good early in the spring, and is also grazed some when growth is resumed following late rains. What little forage value squirreltails have is offset by the injurious effects of their disjointed seedheads.

\section{BIG SQUIRRELTAIL (Sitanion jubatum)} is much like the preceding in habit, but is sometimes taller and the spike rather 


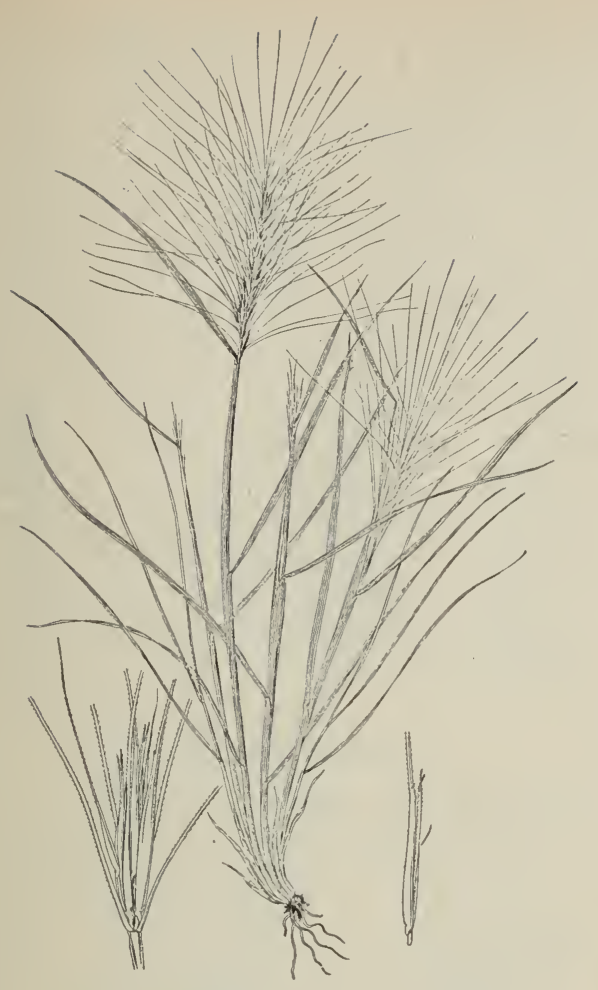

Fig. 56. Squirreltail (Sitanion hystrix).

thicker, and bushy from the numerous slender spreading awns, the awns of glumes and lemmas $3-10 \mathrm{~cm}$ long.

Big squirreltail is essentially confined to the lower elevations. Its forage value is similar to that of squirreltail.

3. HANSEN SQUIRRELTAIL (Sitanion hanseni) is taller and rather less coarse than the other species, mostly $2-3 \mathrm{ft}(60-90$ cm) tall; spike somewhat nodding, 4-8 in $(10-20 \mathrm{~cm})$ long, $3-5 \mathrm{~cm}$ wide, the slender awns $4-5 \mathrm{~cm}$ long.

Dr. G. L. Stebbins, Geneticist, University of California, believes this grass to be of hybrid origin, the parent species being Agropyron spicatum, A. trachycaulum, A. parishii, or Ely. mus glaucus and Sitanion hystrix or S. jubatum.

Hansen squirreltail is confined to the coastal range. It is similar in forage value to squirreltail, though ordinarily less common and so less important.

\section{BOTTLEBRUSH (HYSTRIX)}

Of the two bottlebrushes found in the U. S., one species is found on California range lands.

CALIFORNIA BOTTLEBRUSH (Hystrix californica) is a robust leafy erect perennial, the culms $31 / 2-61 / 2 \mathrm{ft}$ ( $1-2$ meters) tall; blades 1-2 cm wide; spike nodding, 510 in $(12-25 \mathrm{~cm})$ long; spikelets $3-4$ at a node, 3-4 cm long including the awns, somewhat spreading at maturity, the glumes obsolete. (Fig. 57.)

Distribution of California bottlebrush is confined to the coastal counties from Sonoma south to Santa Cruz. (Fig. 58.) It occupies shaded banks and wooded areas near the coast. The tall, coarse stems and broad leafage are palatable to

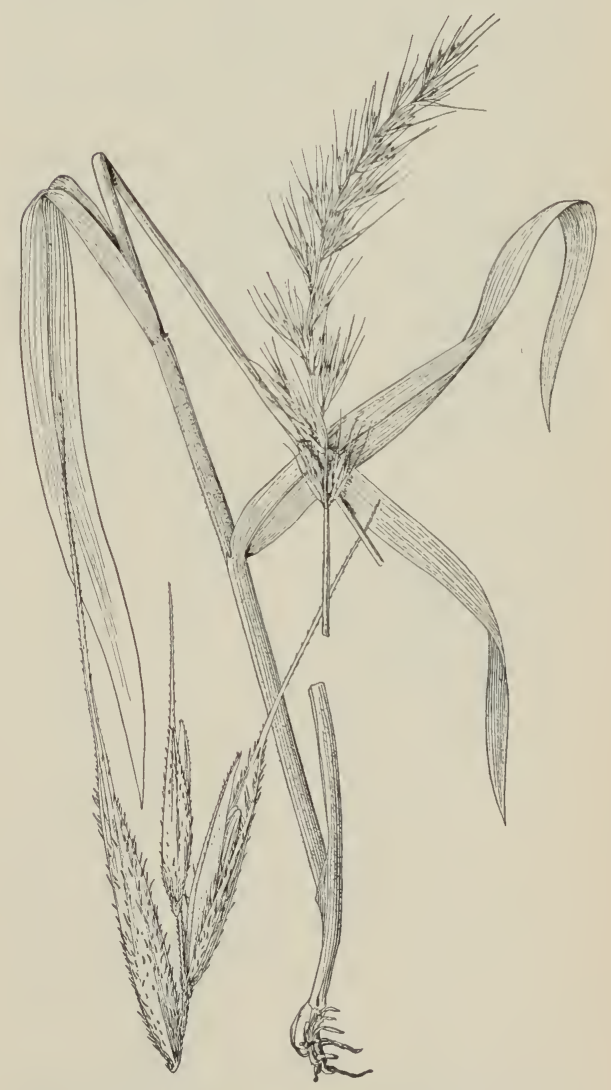

Fig. 57. California bottlebrush (Hystrix californica). 
cattle and horses, and the herbage is sought by sheep when young.

\section{BARLEYGRASSES (HORDEUM)}

Barleygrasses are tufted perennials or annuals, with dense bristly spikes; spikelets in $3 \mathrm{~s}$ at the nodes of a jointed rachis, the central spikelet sessile with 1 perfect floret and a prolonged rachilla segment, the lateral spikelets pediceled, the floret usually reduced or rudimentary; rachis disjointing at the base of each segment, this remaining as a stipe below the attached spikelets. The auricles at the base of the blades are wanting in all California species except $H$. leporinum and the cultivated barley, $H$. vulgare.

Seven barleygrasses grow on California range lands, of which four are important forage grasses. Two of these are perennials and two annuals.

Barleys enjoy a wide elevational range. Common on valley and foothill ranges, they also grow in the high mountains. (Fig. 58.) Though generally occupying open sites, such as meadows, dry grasslands, and parks, some species appear under brush or woodland cover.

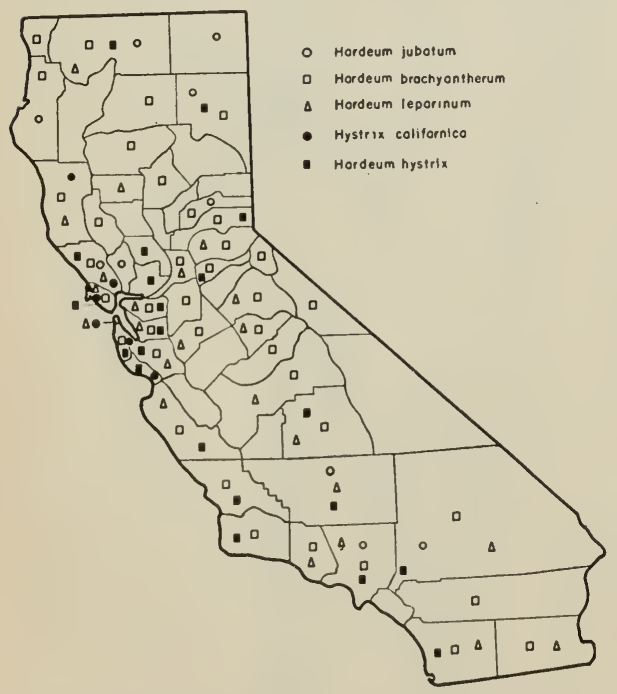

Fig. 58. Distribution of barleygrasses (Hordeum spp.) and California bottlebrush (Hystrix californica).
Because of the stiff sharply barbed awns, two species are mechanically objectionable to livestock, but are grazed with moderate relish in spring and early summer. After the objectionable spikes have dropped and growth is resumed in the fall, barleys furnish late grazing of fair quality. On the whole, when compared to bluegrasses, bromegrasses, or fescues, barleys provide distinctly inferior forage. Seeding habits are strong. Unless carefully grazed, stands spread rapidly on favorable sites, replacing the better forage plants. Rotation grazing, or early mowing on meadow lands infested with barley grasses, will prevent their reseeding and enable the later-maturing, desirable grasses to reproduce.

\section{Key to Species}

Plants perennial; awns slender

Awns 2-5 cm long

2. H. jubatum

Awns mostly less than $1 \mathrm{~cm}$ long

1. H. brachyantherum

Plants annual; awns stouter

Blades with prominent auricles at base

3. $\mathrm{H}$. leporinum

Blades without auricles

4. H. hystrix

1. MEADOW BARLEY (Hordeum brachy. antherum), to which the name $H$. nodosum has been misapplied, is a tufted leafy perennial, mostly $1-2 \frac{1}{2} \mathrm{ft}(30-75 \mathrm{~cm})$ tall, with blades 4-7 mm wide and erect spikes $2-8 \mathrm{~cm}$ long, about $7-10 \mathrm{~mm}$ wide (wider as awns spread at maturity), the joints, with spikelets, including awns, usually about $15 \mathrm{~mm}$ long; florets of lateral spikelets occasionally staminate. (Fig. 59.)

Distribution and habitat: Meadow barley is found chiefly in the foothills and mountains on moist soils along open stream banks or in meadows and parks. It withstands partial shade in brush or aspen stands, but thrives best in moist, open exposures where frequently it occurs in small, nearly pure stands.

Forage value and reproduction: Meadow barley is the most useful of the 


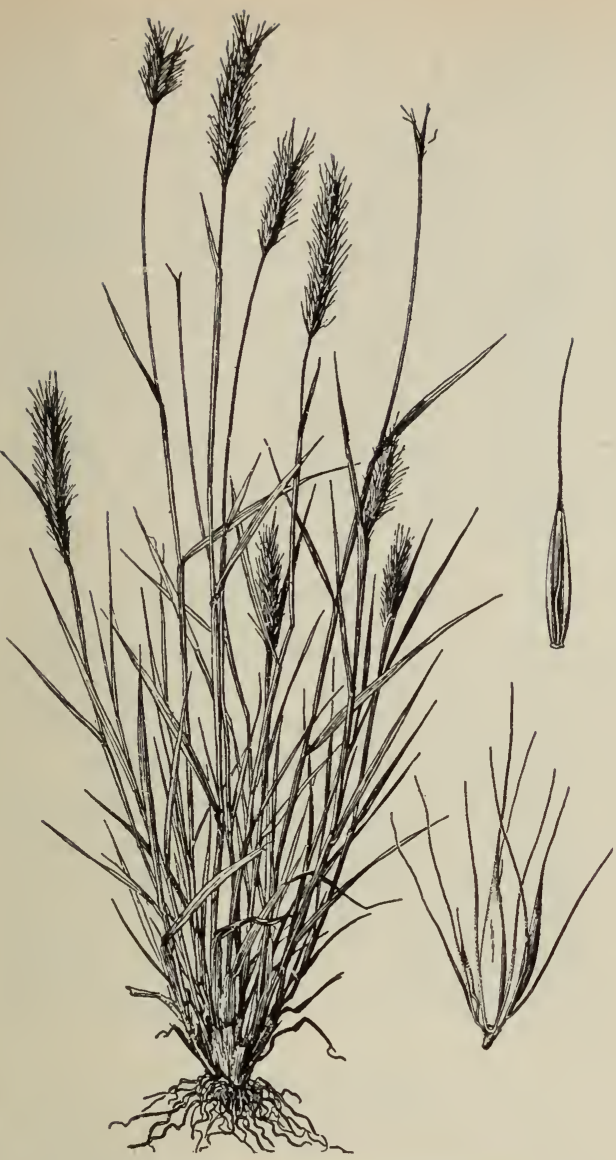

Fig. 59. Meadow barley (Hordeum brachyantherum).

barleygrasses in California. The young plants are readily taken by livestock.

\section{FOXTAIL BARLEY (Hordeum jubatum)} is a densely tufted perennial $1-2 \mathrm{ft}$ $(30-60 \mathrm{~cm})$ tall with a nodding spike 5-10 cm long, as wide or wider, the awns fine, mostly 4-6 cm long. (Fig. 60.)

Distribution and habitat: Foxtail barley, a noxious range grass, grows commonly on valley and foothill ranges, but also extends upward to subalpine elevations in the mountains. It occupies grasslands in moist saline or dry soils, and is also abundant in waste places and in grain and hay fields.

Forage value and reproduction: The forage is of fair quality up to the time the heads develop, but mature herbage is seldom grazed. The troublesome awns are especially injurious to elk and horses when these animals consume the mature herbage. It is inadvisable to feed lambing ewes on foxtail barley hay (11). On areas that cannot be plowed and reseeded, conservative grazing is necessary to reduce the stand of this grass. However, since the heads develop early, it is grazed for only a relatively short period. Under heavy grazing, it tends to replace more valuable forage plants, but the presence of foxtail barley - unlike meadow barley-is especially objectionable in hay (10).

\section{MOUSE BARLEY (Hordeum leporinum)} is a weedy branching annual, the culms mostly 4-8 in (10-20 cm) long; spikes partly enclosed in the inflated upper

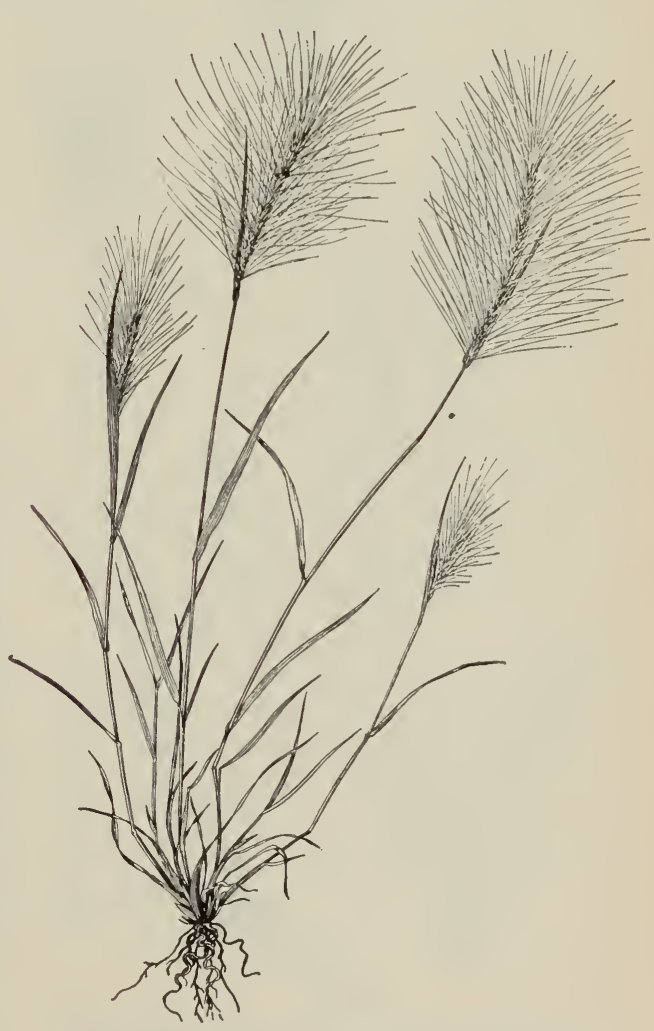

Fig. 60. Foxtail barley (Hordeum jubatum). 
sheaths, 5-10 cm long, rapidly breaking up, the broad lemmas of the sterile florets conspicuous in 2 rows down the middle; awns 3-6 cm long; fertile florets smaller than the sterile. From Europe. (Fig. 61.)

Mouse barley, a naturalized annual, has become the most common barley grass on California ranges. It is especially abundant in valleys and foothills where it frequently forms pure stands. It is of less value for forage than other barleys, and is mechanically most troublesome. Areas infested with this annual should be grazed early or mowed before the heads appear. Although a strong seed producer, mouse barley tends to be replaced under proper range use by the better forage species.

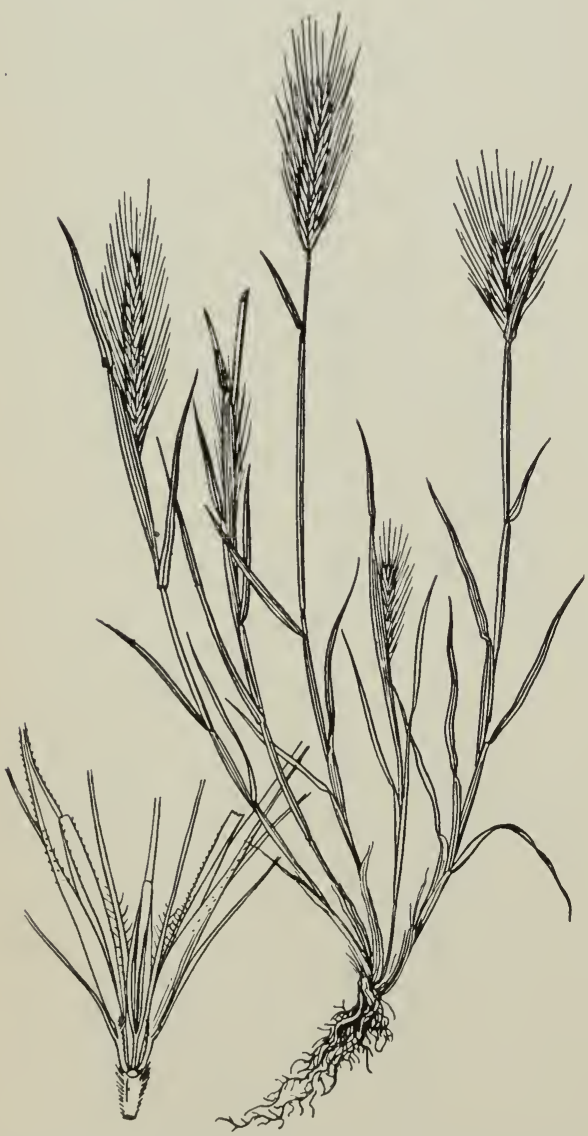

Fig. 61. Mouse barley (Hordeum leporinum).
4. MEDITERRANEAN BARLEY (Hordeum hystrix) is a weedy branching annual, geniculate at base, mostly 6-12 in (15$30 \mathrm{~cm}$ ) tall; foliage more or less pubescent; spike 1.5-3 cm long, the axis tardily breaking up; glumes setaceous. rigid, about $12 \mathrm{~mm}$ long; sterile florets reduced. Fields and waste places.

Mediterranean barley has a wide distribution (fig. 58) and is fairly abundant in some local areas. The young herbage is taken with associated forage plants, but the plant matures early and is then utilized but little.

\section{RYEGRASSES (LOLIUM)}

Ryegrasses are rather slender erect shortlived leafy perennials or annuals, with slender flat spikes; spikelets placed edgewise on the rachis, not overlapping.

Two old-world ryegrasses, perennial ryegrass and Italian ryegrass, occur commonly in California and provide desirable forage. Introduced from Europe, they are now common in the interior valleys and on the foothill ranges of the coast.

\section{Key to Species}

Glumes as long or longer than the spikelets

3. L. temulentum

Glumes shorter than the spikelets

Lemmas nearly or quite awnless

2. L. perenne

Lemmas, at least the upper, awned

1. L. multiflorum

1. ITALIAN (ANNUAL) RYEGRASS (Lolium multiflorum) resembles the following, but is mostly more robust, the blades commonly broader, less glossy; spikelets often longer, with 11-12 florets, the lemmas awned; auricles well developed. (Fig. 62.)

2. PERENNIAL RYEGRASS (Lolium perenne) is a short-lived perennial, $1-2 \mathrm{ft}$ $(30-60 \mathrm{~cm})$ tall, with glossy foliage, the blades 2-4 $\mathrm{mm}$ wide; spike usually slightly nodding, 15-25 cm long; spikelets 6-10 flowered, awnless or nearly so. 


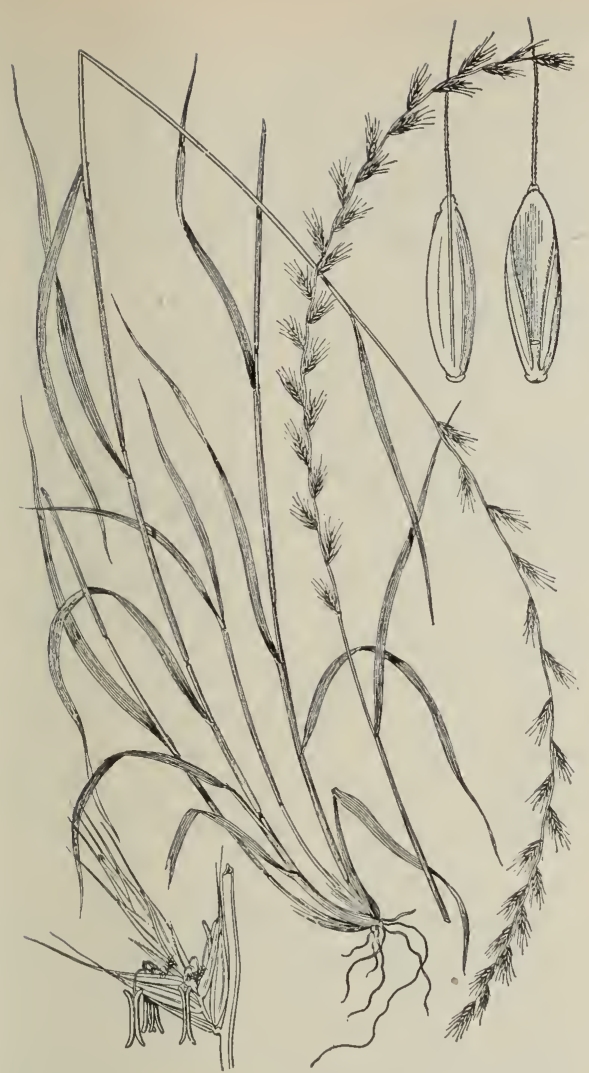

Fig. 62. Italian ryegrass (Lolium multiflorum).

The auricles at base of blades commonly obsolete on most or all leaves of each plant.

Italian ryegrass is the more valuable species because of its much greater abundance. Both are highly palatable to livestock. They start growth early in the season and contribute appreciably to the forage crop on the foothill ranges. Although best adapted to fertile, deep soils with abundant moisture, they are commonly used for reseeding burned or cleared brush ranges of the coast and interior (36). Since they require a moderately long, warm growing season in which to produce seed and complete their growth cycle, ryegrasses are not suited to seeding on high mountain ranges. Under favorable conditions a large seed crop ripens in July and August.

3. DARNEL (Lolium temulentum), sometimes called poison darnel, is a rather tall annual, with a somewhat stiffer spike 6-10 in $(15-25 \mathrm{~cm})$ long; spikelets appressed, the glume about 1 in $(20-25$ $\mathrm{mm}$ ) long, firm, pointed; florets plump, with a slender awn.

Darnel occurs most commonly in grainfields and waste places. It has been collected from Humboldt to San Diego counties. The seedheads of this grass occasionally poison cattle, horses, and sheep. Some investigators have concluded that a fungus containing the poisonous substances infests the seed. No outstanding cases of poisoning have been reported in California. Where practicable, the plant should be prevented from going to seed by mowing. In range reseeding, seed sources free from darnel should be used.

\section{GOATGRASS (AEGILOPS)}

Weedy annuals with scant, stiff foliage and cylindrical spikes, spikelets with long stiff rough awns. Introduced from eastern Europe, all injurious to grazing animals. Fortunately but one species is common in California, barb goatgrass (A. triuncialis). At maturity the spikes fall entire, forming a sharp-pointed, strongly barbed structure which works its way into the mouths and noses of grazing animals and into the wool of sheep. It occurs commonly as a weed in grainfields and waste ground, being locally common in Calaveras and El Dorado counties, and between Sacramento and Stockton. It is more scattered elsewhere. Its forage value at any season is practically nil. 


\section{OAT TRIBE (AVENEAE)}

Spikelets 2-several-flowered in open or contracted panicles; glumes usually as long or longer than the first lemma, commonly longer than all the florets; lemmas usually awned from the back, the awn mostly bent and twisted. Some genera in this tribe, e.g. Koeleria, approach Festuceae. A small tribe, but containing the cultivated oat and several important forage grasses, of which wild oats are especially valuable.

\section{KEY TO GENERA}

Spikelets awnless or lemmas rarely minutely awned

Spikelets awned

20. Koeleria (p. 79)

Spikelets large, $1.5-2 \mathrm{~cm}$ long, rarely $1 \mathrm{~cm}$; awns prominent

Spikelets 2-3 flowered, lemmas acuminate, toothed; plants annual

Spikelets several-flowered; lemmas bifid; plants perennial

17. Avena (p. 74)

Spikelets not more than $8 \mathrm{~mm}$ long, 2-3 flowered, awned

18. Danthonia (p. 75)

Spikelets falling entire; first floret awnless, the second with a hooked awn; plant velvety

Spikelets not falling entire, the glumes persistent; plants not velvety

Florets 2, the lower staminate, awned, the upper perfect, awnless

23. Holcus (p. 81)

Florets 2 or more, all alike except the reduced upper ones Lemmas keeled, the awn from above the middle Lemmas convex, awned from below the middle

22. Arrhenatherum (p. 81)

21. Trisetum (p. 79)

19. Deschampsia (p. 77)

\section{WILD OATS (AVENA)}

Two European introduced annual species of wild oats are found in California. Of these, wild oats is more abundant than slender wild oats, but both are high in forage value and respond similarly to grazing management. (Fig. 63.)

\section{Key to Species}

Teeth of lemma acute, short 1. A. fatua Teeth of lemma awned, $4 \mathrm{~mm}$ long

2. A. barbata

1. WILD OATS (Avena fatua) is a stout leafy annual, branching at base; culms mostly $1 \frac{1}{2}-2 \frac{1}{2} \mathrm{ft}(45-75 \mathrm{~cm})$ tall; panicle large, loose and open; spikelets pendulous, about $2.5 \mathrm{~cm}$ long, the glumes strongly nerved, shining; lower part of lemmas and rachillas clothed with long stiff brownish hairs. (Fig. 64.)

Distribution and habitat: Wild oats is an abundant and valuable grass of valley and foothill ranges. Although it does well on a variety of soils, best growth is obtained on moist, rich adobe lands, where it makes up the bulk of the early grazing.
Forage value and reproduction: Wild oats ranks high as a forage producer. It is palatable and nutritious until after the seed is cast. In the early growth stages, plants of wild oats are kept palatable by relatively high contents of crude protein

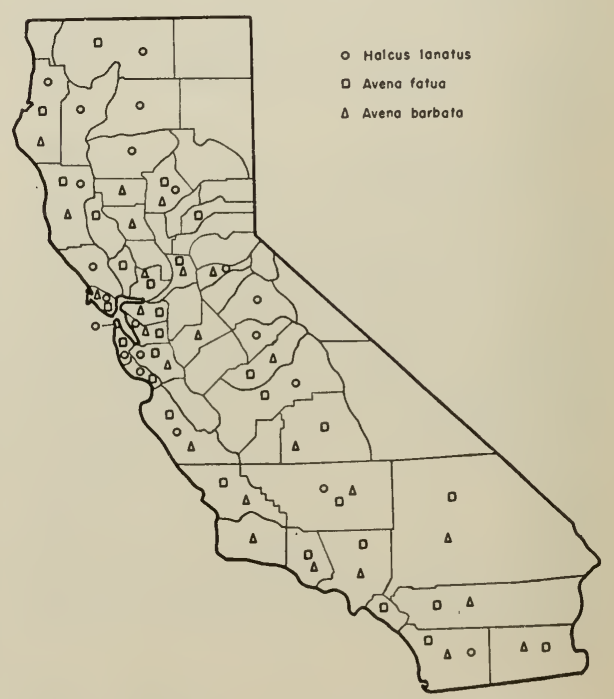

Fig. 63. Distribution of velvetgrass (Holcus lanatus) and wild oats (Avena spp.). 


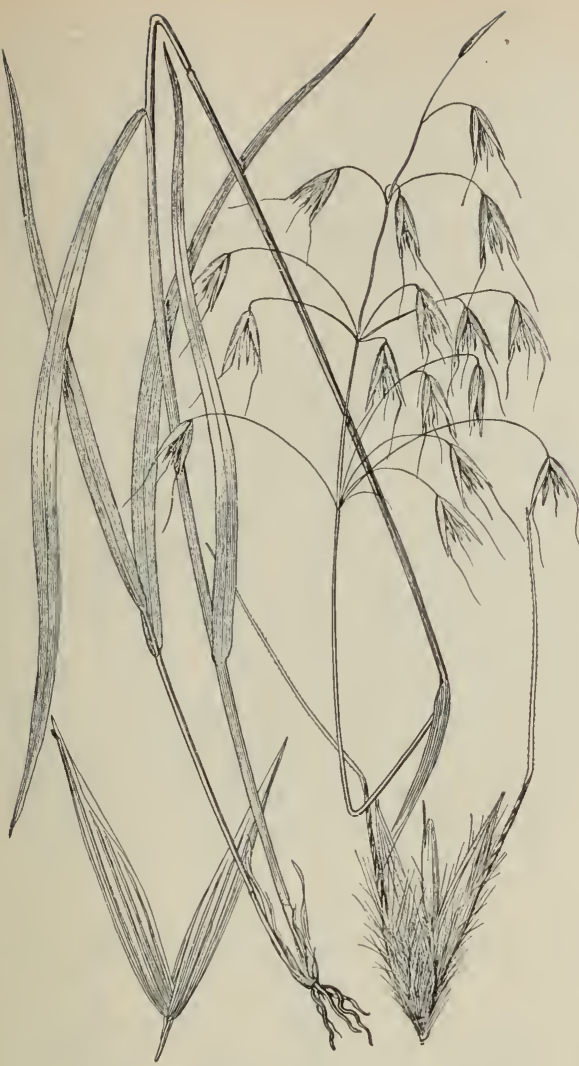

Fig. 64. Wild oats (Avena fatua).

and minerals. (Samples from which nutrient analyses were made probably contained both wild oats and slender wild oats.) By the time the plants dry, however, wild oats are the highest in fiber content of the annual forage plants. This, together with the fact of rapid decline in protein and minerals following maturity, probably accounts for the low value of wild oats as late forage (16). Hay yields from pure stands are as high as $11 / 2$ tons per acre. Stands of wild oats produce a heavy seed crop if grazing is deferred until after the middle of March. The seed is cast in June. Fall grazing assists in planting the seed and hastens revegetation of the stands.

2. SLENDER WILD OATS (Avena barbata) is similar to the preceding, mostly slen- der; panicle branches and pedicels filiform, teeth of the lemma awned, $4 \mathrm{~mm}$ long; the stiff hairs on lemma and rachilla pale or reddish.

Distribution: Slender wild oats is one of the most common range plants over the foothill section in general.

Forage value: This plant is considered good forage during the winter and spring growth period, when it makes more growth than many of the other species; but during the summer it is not readily taken by livestock (60). Chemical analyses of slender wild oats at varying growth stages reveal a marked decline in the levels of important constituents, especially of crude protein (13), when the plant dries.

\section{OATGRASSES (DANTHONIA)}

Oatgrasses are tufted shallow-rooted perennials, with small panicles with few rather large spikelets, the glumes exceeding the 5 or 6 florets; lemmas 2 toothed with a flat, twisted and bent awn from the base of the teeth. All our species bear self-pollinated 1-2-flowered spikelets at the lower nodes, enclosed in the sheaths, the nodes readily disjointing at maturity, the seed larger than that of terminal panicles.

Four oatgrasses grow scatteringly to fairly densely on California ranges, and contribute appreciably to the forage crop in some areas. (Fig. 65.) Oatgrasses range from sea level to $8000 \mathrm{ft}$. They thrive in open, moist parks or meadows, but at lower elevations grow in grassland, bush, or open timber stands. They are intermediate in the succession of grassland vegetation, and are commonly associated with bromegrasses, bluegrasses, and fescues.

Oatgrasses are leafy and palatable to livestock. Animals relish the large proportion of fine, basal leafage and graze the individual plants with gusto. At lower altitudes flower stalks appear in April, and by June the seed is cast. These dates are correspondingly later with in- 


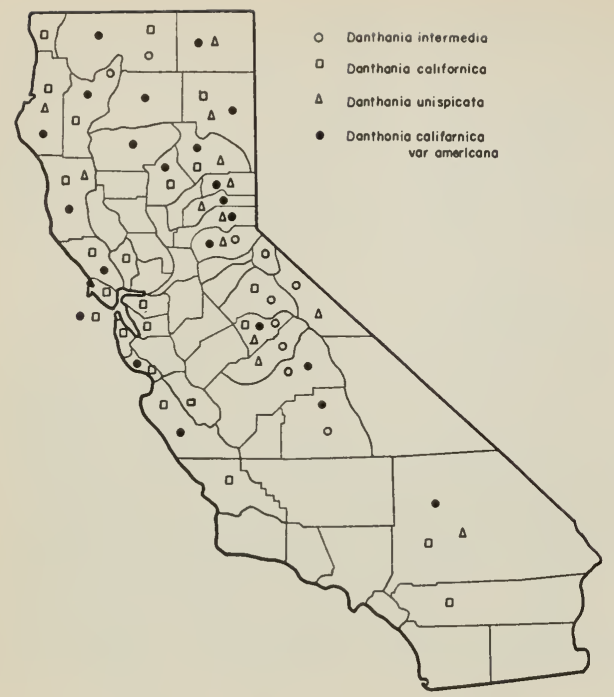

Fig. 65. Distribution of oatgrasses (Danthonia spp.).

creased elevation. Seeds are large and need trampling into the ground to assure good germination.

\section{Key to Species}

Spikelet usually solitary or with 1 or 2 reduced spikelets borne below it

4. D. unispicata

Spikelets few to several in an open or narrow panicle

Awns of teeth and dorsal awn of lemma much longer than the body of the floret

5. D. pilosa

Awns of teeth and dorsal awn of lemma shorter than the body of the floret

Panicle narrow, the pedicels appressed; spikelets mostly 4-6 1. D. intermedia Panicle open, the pedicels spreading or reflexed, spikelets $2-4$

Foliage glabrous; culms $1 \frac{1}{2}-3 \frac{1}{4} \mathrm{ft}(45-$ $100 \mathrm{~cm}$ ) tall

2. D. californica

Foliage pilose; culms mostly shorter; spikelets usually smaller

3. D. californica var. americana

\section{TIMBER OATGRASS (Danthonia inter-} media) is a densely tufted perennial, mostly $6-20$ in $(15-50 \mathrm{~cm})$ tall with a dense mass of short basal leafage; panicles narrow, 1-2 in $(2-5 \mathrm{~cm})$ long, the purple spikelets $12-15 \mathrm{~mm}$ long, on short pedicels, crowded. (Fig. 66.)
Distribution and habitat: Timber oatgrass is confined to the summer ranges in the Sierra Nevada in California. It occurs mostly in open, moist parks and meadows, but at lower altitudes it may grow in the shade of coniferous timber and more sparingly in the oakbrush cover.

Forage value and reproduction: The succulent basal leafage of timber oatgrass is well liked by livestock, but the plant is not abundant enough in California to be of outstanding forage value. It withstands heavy grazing, due probably to its production of large self-fertilized spikelets (cleistogenes) which are hidden at the lower stem joints. These basal cleistogamous spikelets enable stands to reproduce even though grazing retards the development of flower stalks, where normally the seed is produced.

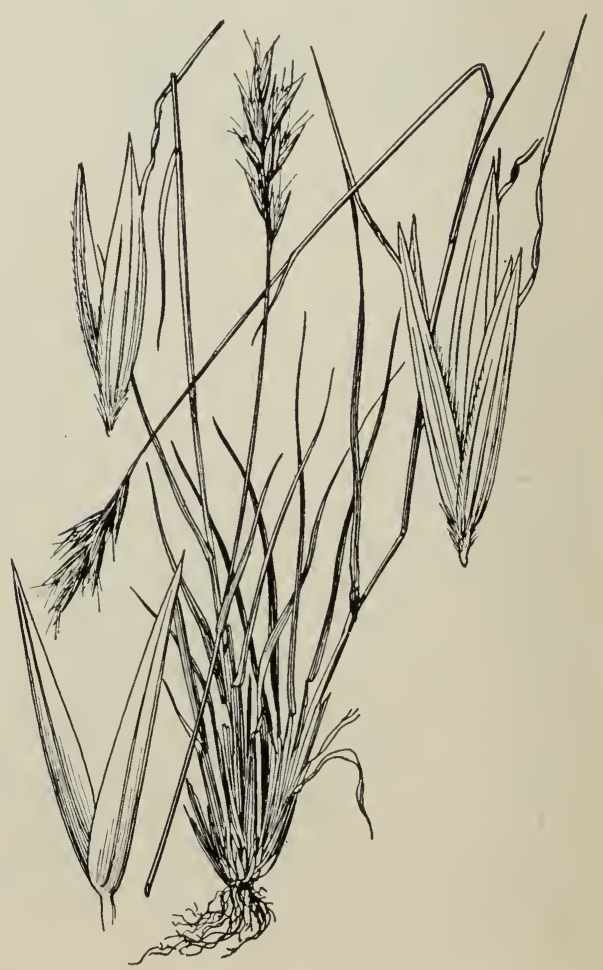

Fig. 66. Timber oatgrass (Danthonia intermedia). 


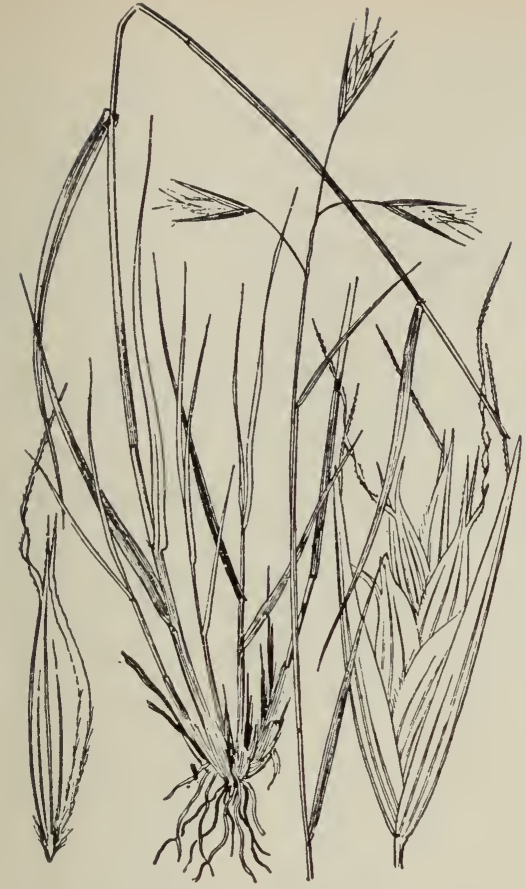

Fig. 67. Californic oatgrass (Danthonia californica).

2. CALIFORNIA OATGRASS (Danthonia californica $)$ is mostly $2-3 \mathrm{ft}(60-90 \mathrm{~cm})$ tall, sometimes shorter or taller, in dense leafy tufts, foliage glabrous; spikelets usually 3 or 4 , the glumes $15-20 \mathrm{~mm}$ long; teeth of the lemma awned, the flat middle awn 8-12 mm long. (Fig. 67.)

Distribution and habitat: California oatgrass, a fairly large, leafy perennial, occurs throughout the coast ranges and mountains of northern California. It thrives in both open and partly shaded grass areas up to $8000 \mathrm{ft}$.

Forage value: The early leafage of California oatgrass is avidly grazed by all stock, so much so, in fact, that observers have come to regard this plant as an "ice cream" plant on foothill ranges along the coast. (An "ice cream" or "dessert" plant is one which occurs sparingly and is prized by livestock above all others.)

3. AMERICAN OATGRASS (Danthonia californica var. americana) is similar to the preceding, but the culms are commonly spreading and not so tall; foliage pilose, sometimes sparingly so; spikelets mostly smaller. Intergrades with the species, plants up to $90 \mathrm{~cm}$ tall with pilose foliage and spikelets with glumes to 2 $\mathrm{cm}$ long occurring rather rarely.

This variety occurs on dry sites over the same general area as California oatgrass and, though less abundant, it has much the same forage value as the species.

4. ONE-SPIKE OATGRASS (Danthonia unispicata) is densely tufted, the culms $6-10$ in $(15-25 \mathrm{~cm})$ tall, widely spreading; foliage pilose, the hairs on the sheaths spreading or reflexed; panicle reduced to a single spikelet, often with 1 or 2 reduced spikelets below, pedicels appressed; glumes mostly 12-15 mm long.

Stands of one-spike oatgrass are limited to intermediate elevations in the Sierra Nevada and in northeastern California, where they occur on the high desert or lava areas. One-spike oatgrass is of about equal rank with timber oatgrass in forage.

\section{AUSTRALIAN OATGRASS (Danthonia} pilosa) is a densely tufted perennial, $1-21 / 2 \mathrm{ft}(30-75 \mathrm{~cm})$ tall, leafy; panicles rather loose, 2-3 in (5-8 cm) long; spikelets about 1 in $(2 \mathrm{~cm})$ long, the florets with a long hairy callus, glabrous on the back, the awns much longer than the florets. Introduced from Australia.

Australian oatgrass is locally abundant in Humboldt, Alameda, and Santa Barbara counties, and adjoining areas. The herbage is sought by livestock to about the same extent as that of the native perennial oatgrasses.

\section{HAIRGRASSES (DESCHAMPSIA)}

Hairgrasses are slender tufted perennials or annuals, with narrow or inrolled blades and loose or narrow panicles with 2-flowered spikelets, the lemmas truncate and toothed at summit, awned from near the base. 


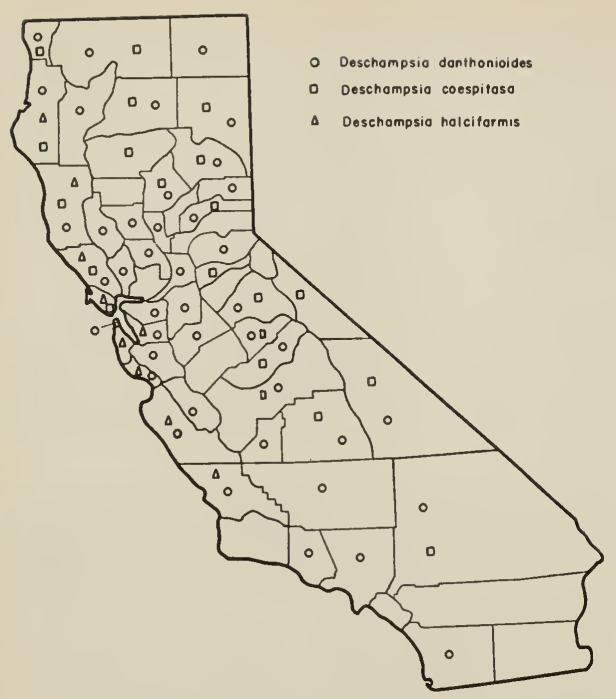

Fig. 68. Distribution of hairgrasses (Deschampsia spp.)

Four hairgrasses are found on California range lands. Of the three species important for forage, two are perennials and one an annual. (Fig. 68.)

\section{Key to Species}

Plants annual, awns bent 3. D. danthonioides Plants perennial; awns nearly straight

Panicle open

1. D. caespitosa

Panicle narrow, dense

2. D. holciformis

1. TUFTED HAIRGRASS (Deschampsia caespitosa) grows in dense tufts, $1 \frac{1 / 2^{-}}{}$ $31 / 4 \mathrm{ft}(45-100 \mathrm{~cm})$ tall, with abundant rather stiff foliage; panicle pyramidal, the branches whorled, spikelet-bearing towards the ends; spikelets $4-5 \mathrm{~mm}$ long, shining. (Fig. 69.)

Distribution and habitat: Tufted hairgrass occurs from Sonoma County in the Coast Range to the northern border of the state, and southward into Tulare County in the Sierra at altitudes between 5000 and $10,000 \mathrm{ft}$. It is best adapted to moist or semimarshy soils of open areas, where it frequently forms pure stands. On dry, shady sites it is not so luxuriant, and is found mixed with sedges, trisetums, and perennial forbs. Tufted hairgrass is the key indicator in determining condition and utilization of mountain meadows (44).

Forage value and reproduction: Animals admitted to tufted-hairgrass range before the plants are mature consume the leafage with relish. On its normally moist habitat, the plant furnishes fresh succulent grazing all summer. It reproduces well by stooling and is resistant to heavy grazing. The seed crop matures late and, though not generally large, appears to germinate well.

2. CALIFORNIA HAIRGRASS (Deschampsia holciformis) is rather robust, densely tufted, mostly 2-4 ft $(60-125 \mathrm{~cm})$ tall; panicle $4-81 / 2$ in $(10-25 \mathrm{~cm})$ long, narrow, dense, purplish to brownish; spikelets $6-8 \mathrm{~mm}$ long, the awn erect.

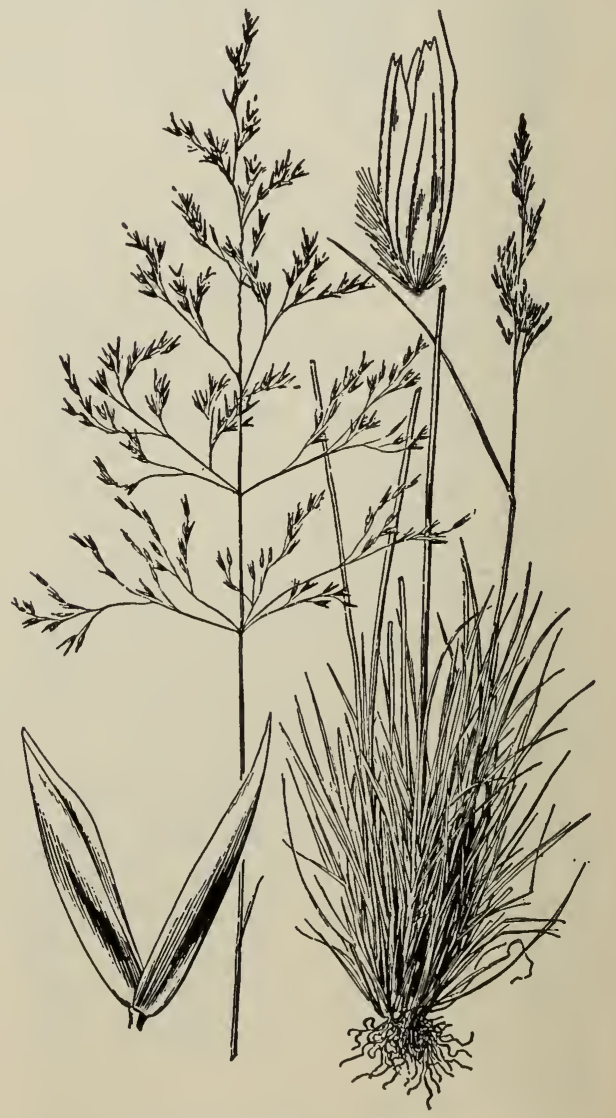

Fig. 69. Tufted hairgrass (Deschampsia caespitosa). 
California hairgrass is confined to a narrow coastal belt extending from San Luis Obispo County to the northern border of the state. Occurring principally in marshy and sandy areas near the coast, it is not always available to grazing animals. Although grazed by cattle and horses, it is not abundant enough to be considered more than a "filler."

\section{ANNUAL HAIRGRASS (Deschampsia} danthonioides) is a very slender, shallow-rooted annual, 6-24 in $(15-60 \mathrm{~cm})$ tall, with scant foliage; panicle open, $4-8$ or 10 in (10-25 cm) long; spikelets 5-8 mm long; awn bent.

Distribution and habitat: Annual hairgrass is widely distributed throughout the state. It occurs in the Coast Range, the mountains of northern California, and in the Sierra Nevada. It grows on all soil types from sea level to $10,000 \mathrm{ft}$.

Forage value: When green, the rather sparse foliage is eaten by livestock, but its period of succulence is too short to provide much nutritious grazing. Even where abundant, it is not of high forage value; it is consequently ranked as a filler along with California hairgrass.

\section{JUNEGRASS (KOELERIA CRISTATA)}

Junegrass, the only important forage species in this genus, is a densely tufted perennial, 1-2 ft $(30-60 \mathrm{~cm})$ tall with abundant foliage, and a narrow dense erect panicle 5-12 cm long; spikelets 2-flowered, compressed, 4-5 mm long, shining; lemmas awnless. (Fig. 70.)

Distribution and habi:at: Junegrass is most abundant in the coast ranges and the northern mountains of California, but also occurs at high altitudes in the Sierra from Tuolumne County south to Tulare County. (Fig. 71.) Its elevational range is from sea level to $10,000 \mathrm{ft}$. Although best adapted to well-drained soils of open timber stands, it also grows on dry, exposed sites. It is early in succession, and typically associated with various forbs and perennial bromegrasses.

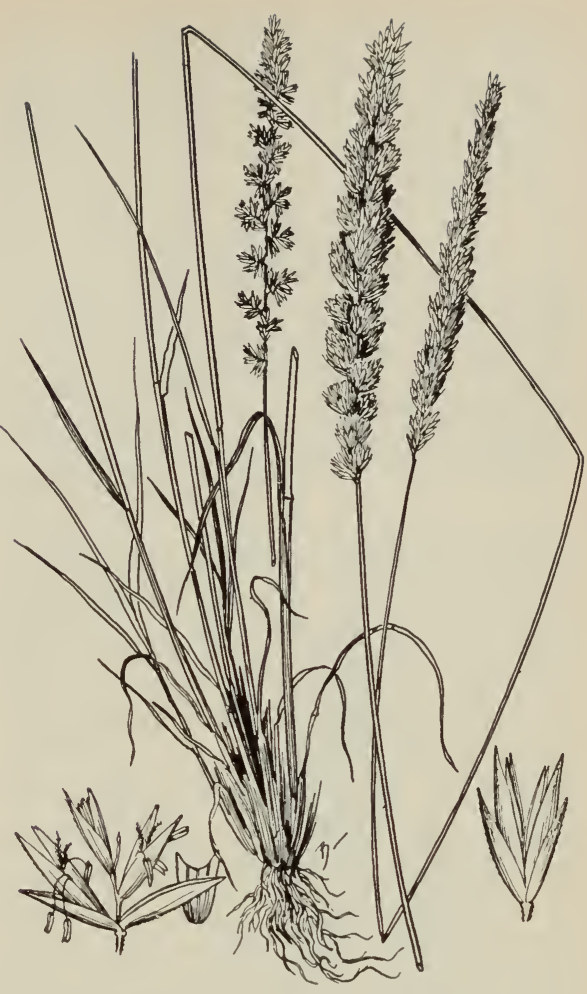

Fig. 70. Junegrass (Koeleria cristata).

Forage value and reproduction: The basal leafage of junegrass furnishes succulent forage for all classes of livestock. Sheep relish the early growth nearly as much as cattle and horses, but do not graze the stalks after seed maturity. On areas where junegrass is abundant, "range readiness"-the date when a range can be grazed without injury-is determined by the appearance of flower stalks, or at about ten days to two weeks after growth has started. Seed matures from July to September, the exact date depending on the altitude. The normally abundant seed crop, though of low viability, enables adequate maintenance of even heavily grazed stands.

\section{TRISETUM}

Trisetums are tufted leafy perennials with panicles of 2-3-flowered spikelets, the lemmas acute, awned from above the 
middle. Of the five trisetums in California only two species-nodding trisetum and spike trisetum-are abundant enough to be important forage producers. (Fig. 71.)

\section{Key to Species}

Panicle dense, spikelike

Panicle loose, open and nodding

Panicle relatively few-flowered, lax or drooping; florets distant

2. $T$. cernuum

Panicle many-flowered; florets not distant

3. $T$. canescens

\section{SPIKE TRISETUM (Trisetum spicatum)}

is densely tufted with abundant basal foliage; culms 8-20 in $(20-45 \mathrm{~cm})$ tall; panicle $2-4 \frac{1}{2}$ in $(5-12 \mathrm{~cm})$ long; spikelets 4-6 mm long; awns divergent, 5-6 mm long. (Fig. 72.)

Distribution and habitat: Spike trisetum is confined to the high summer ranges of the Sierra Nevada, where it occurs from $7000 \mathrm{ft}$ up. It is a tufted perennial bunchgrass typical of open, moist alpine and subalpine sites, but also withstands shade and dry soils. Although seldom occurring in pure stands, it is widely distributed over its entire range.

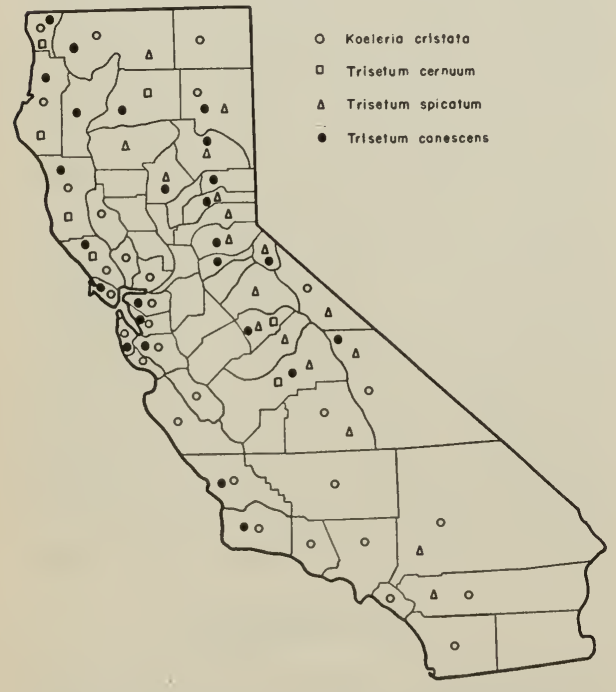

Fig. 71. Distribution of junegrass (Koeleria cristata) and trisetums (Trisetum spp.).

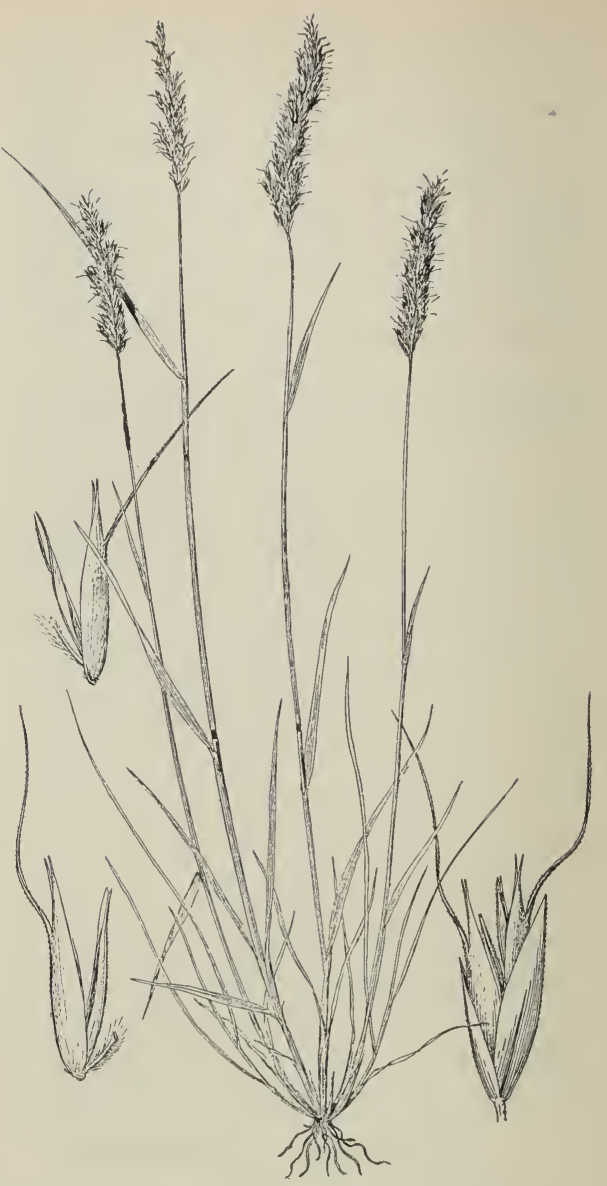

Fig. 72. Spike trisetum (Trisetum spicatum).

Forage value and reproduction: The tender basal leafage of spike trisetum remains succulent throughout the season and is avidly grazed by all kinds of livestock, even late in the autumn. At medium elevations the seed ripens in $\mathrm{Au}$ gust, whereas at higher altitudes seed maturity continues until inclement weather arrests development. Consequently the viability of seed at high altitudes is low (48).

2. NODDING TRISETUM (Trisetum cernuum) has lax culms $2-4 \mathrm{ft}(60-120$ $\mathrm{cm})$ tall, in smaller tufts, and lax blades 6-10 $\mathrm{mm}$ wide; panicle mostly $8-12$ in (20-30 cm) long, loose, drooping, the 
slender branches spikelet-bearing towards the ends; spikelets 8-12 mm long; awns spreading, 5-10 mm long.

Nodding trisetum occurs chiefly in the coast ranges of northern California, and in limited abundance in the San Jacinto Mountains in the southern part of the state. It is an important forage plant on timbered ranges, where it thrives in moist, shady woods up to $5000 \mathrm{ft}$. Although not as abundant as spike trisetum, the leafy foliage is palatable to most livestock.

3. TALL HAIRGRASS (Trisetum canescens $)$ is $2-4 \mathrm{ft}(60-120 \mathrm{~cm})$ tall, foliage usually softly pilose to canescent; panicle narrow but loose, 10-25 cm long; spikelets about $8 \mathrm{~mm}$ long; awns loosely twisted below, about $12 \mathrm{~mm}$ long.

This species occurs from Del Norte and Siskiyou counties in the Sierra and coastal mountains southward. It is a component of mountain meadow vegetation and grows along ravines and streams. The palatability rating is moderately high and the cover, though never dense, is utilized closely if grazed when succulent.

\section{TALL OATGRASS (ARRHENATHERUM ELATIUS)}

Tall oatgrass is a tall, leafy perennial with loose, narrow, shining panicle 6 to 12 in $(15-30 \mathrm{~cm})$ long, the short branches spikelet-bearing from the base; spikelets 7-8 mm long; awn of lower floret 12-15 mm long, geniculate. Cultivated in northern humid regions of the United States and widely spontaneous in the northeastern states. Introduced from Europe.

This grass is a long-lived perennial suitable for seeding permanent pastures. In California it has been used with some success in the northeastern portion and along the coast as far south as Santa Barbara County (36). In suitable habitats hay and pasturage yield is high. The herbage is relished by all stock.

\section{VELVETGRASSES (HOLCUS)}

Of the two species of this genus found in California, only one is important on the range lands.

VELVETGRASS (Holcus lanatus) is a tufted leafy grayish-velvety perennial, $11 / 2-3 \mathrm{ft}(45-90 \mathrm{~cm})$ tall, with dense soft purplish-gray panicles; spikelets falling entire; lower floret perfect, awnless, the upper staminate, the lemma with a hooklike awn near the summit. Originally introduced from Europe. (Fig. 73.)

Distribution and habitat: Velvetgrass

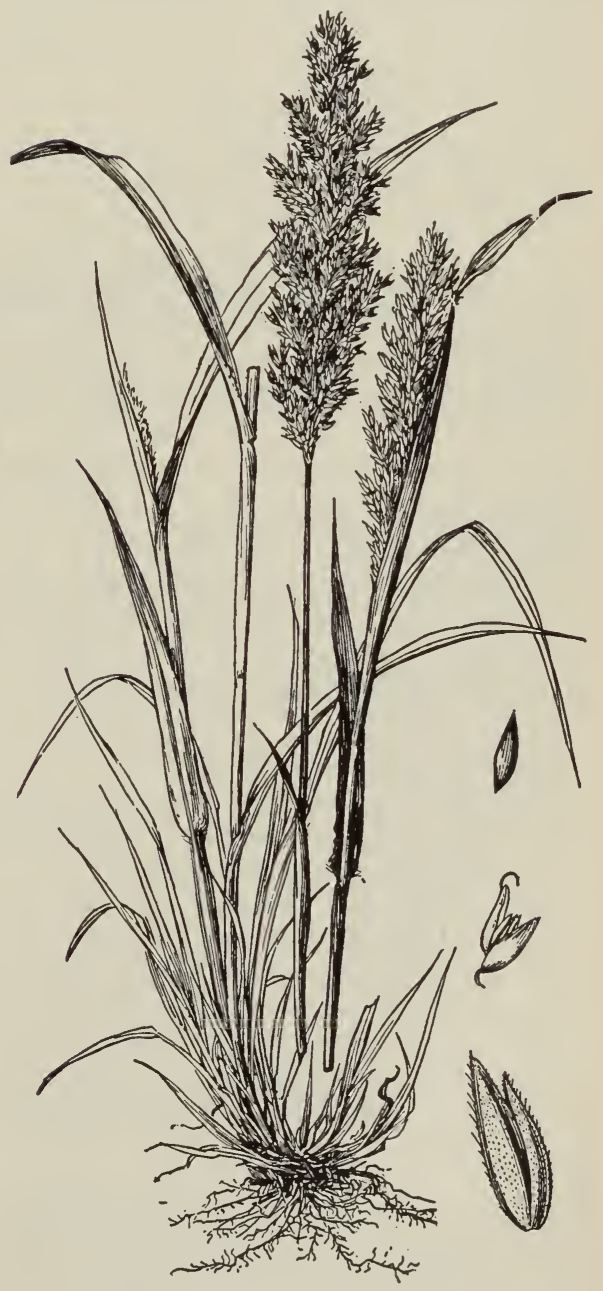

Fig. 73. Velvetgrass (Holcus lanatus). 
has become naturalized in many parts of the United States, and in virtually all but the desert regions of California. (Fig. 63.) It does best in moist meadows of low to medium altitudes throughout the state, but also grows well in light shade and on dry clay soil of the coastal range.

Forage value and reproduction: The soft velvety foliage is not greatly relished by stock, but is grazed to some extent before the seed stalks appear. Although thriving best on moist, rich soils, it is important on the range because of its capacity to grow on poor sites. It is a heavy seed producer and stands are easily maintained. Velvetgrass is low in the succession of plant cover and is often replaced by more desirable forage species when ranges are grazed conservatively.

\section{TIMOTHY TRIBE (AGROSTIDEAE)}

Spikelets l-flowered, in open or contracted panicles; glumes mostly well developed; lemmas awnless or awned, hardened in Stipa, Oryzopsis, and Aristida.

\section{KEY TO GENERA}

Lemma with a 3-parted awn, no line of demarcation between awn and lemma 31. Aristida (p. 102) Lemma awnless or with a simple awn

Lemma indurate, terete or nearly so, awned, a line of demarcation between awn and lemma Awn conspicuous, persistent, twisted and bent; lemma more or less cylindric, with a sharp hairy callus at base

25. Stipa (p. 86)

Awn readily falling, not twisted; callus short, oblique (sharp-pointed in $\mathrm{O}$. hymenoides)

30. Oryzopsis (p. 100)

Lemma membranous or thinner

Spikelets falling entire; glumes and lemma about equal

Spikelets not falling entire, glumes persistent

Glumes longer than the lemma

Glumes compressed, ciliate on the keel, abruptly awned; panicle dense, cylindric or ovoid

27. Phleum (p. 95)

Glumes not compressed, not ciliate on the keel

Glumes saccate at base; panicle dense, shining

Glumes not saccate; panicle open or contracted

32. Cinna (p. 103)

Floret bearing a tuft of hairs at the base, the hairs at least half as long as the lemma; palea well developed; rachilla prolonged behind the palea, hairy

26. Calamagrostis (p. 91)

Floret without hairs at base, or (in A. hallii) with hairs less than half as long as the lemma; palea usually small or wanting

24. Agrostis (p. 83)

Glumes shorter than the lemma (nearly as long in a few species of Muhlenbergia)

Lemma awned from the tip or mucronate, 3-nerved

Lemma awnless, not mucronate, 1-nerved

28. Muhlenbergia (p. 96)

29. Sporobolus (p. 99) 
24. REDTOPS Or BENTGRASSES (AGROSTIS)

Redtops are leafy perennials or annuals in tufts or with rhizomes; culms (of the perennials) simple; panicles narrow to open; spikelets small, the glumes longer than the florets; lemma awned or awnless; palea obsolete in most species, a small palea developed in $A$. palustris and $A$. alba; rachilla not prolonged.

There are 24 redtops in the state. Of the six perennials important for forage, two were introduced into the U. S. from Europe and have become naturalized on California range lands. (Fig. 74.)

Redtops grow over a wide elevational range. Native species commonly occur near sea level along the coast or in the valleys, and extend upward in the mountains to above timberline. They are moisture-loving and occupy moist to wet, rich soils in open meadows or partly shaded parks and woodlands. One species can even grow partially submerged in water, whereas others occupy relatively dry sites. Creeping bent, its name indicating its decumbent, stoloniferous habit of growth, is used as a lawn grass and on golf courses where Kentucky bluegrass

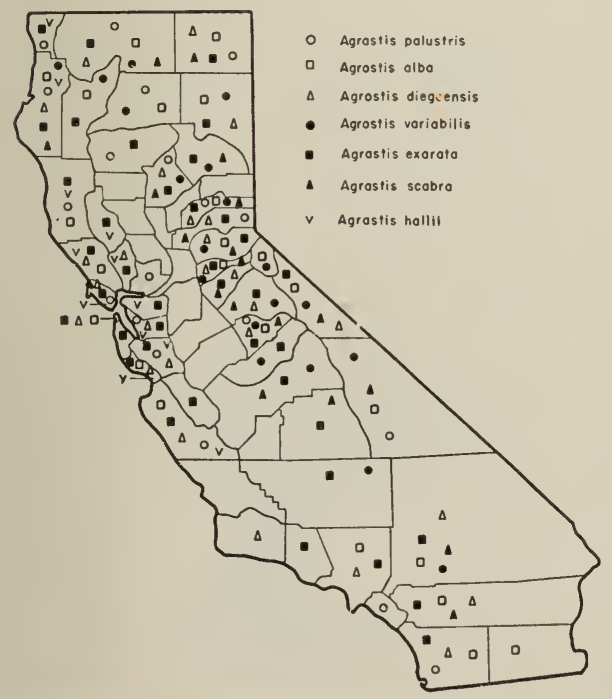

Fig. 74. Distribution of redtops (Agrostis spp.) does not thrive because of climate and soil.

Where plentiful, redtops are highly regarded as forage plants. As the habitat is damp or wet, they grow throughout the grazing season and furnish green forage after most plants have dried. Although all species are palatable when young, a few are not grazed readily after heading out. Cattle and horses utilize the herbage better than sheep. Redtops provide choice forage for elk, but deer do not greatly relish them (10). Meadow redtop and creeping bent are valuable hay grasses. All forms are strong seed producers, and the sod-formers endure heavy grazing.

\section{Key to Species}

Plants with creeping stolons or rhizomes

Plants stoloniferous, widely creeping: panicle narrow, rather dense

3. A. palustris

Plants with rhizomes

Panicle branches in whorls, spreading, somewhat contracted at maturity; spikelets $2 \mathrm{~mm}$ long 2. A. alba Panicle branches ascending; spikelets 3 $\mathrm{mm}$ long

Lemma awnless, hairs at base 1-2 mm long 5. A. hallii Lemma awned or awnless, hairs at base minute 4. A. diegoensis

Plants tufted

Panicle narrow

Culms slender, in dense tufts; blades seldom more than $1 \mathrm{~mm}$ wide 6 . A. variabilis Culms stout; blades mostly $3-8 \mathrm{~mm}$ wide

1. A. exarata

Panicle very open

7. A. scabra

1. SPIKE REDTOP (Agrostis exarata) varies greatly in size, the culms from 8 in$4 \mathrm{ft}(20-120 \mathrm{~cm})$ tall, the blades from narrow to $8 \mathrm{~mm}$ wide, and panicles $2-10$ in (5-30 cm) long, mostly $10-20 \mathrm{~cm}$, the many-flowered branches commonly in dense whorls (often distant at base of panicle), spikelet-bearing to the base; spikelets mostly 3-4 mm long, the glumes sharp-pointed, very scabrous on the keel.

Distribution and habitat: Spike redtop is widely distributed in the mountains of 
northern California. It extends southward in the Sierra Nevada to Tulare County to altitudes of $10,000 \mathrm{ft}$. Although a moisture-loving species, its water requirements are less exacting than those of some redtops. It occurs commonly along streams, in moderately moist meadows, and in moist semishaded woodlands.

Forage value and reproduction: All kinds of livestock relish the herbage of spike redtop throughout the growing season, partly because the herbage stays green until late in the summer. Being abundant and widely distributed it ranks next to meadow redtop in importance, and is the most valuable native redtop found on California range lands. Stands produce a moderate seed crop of fair viability, ripening in August and September according to altitude.

2. REDTOP (Agrostis alba) has erect relatively stout culms, 2-4 ft $(60-120 \mathrm{~cm})$ tall, and strong creeping rhizomes; blades 5-8 mm wide, scabrous; panicles mostly pyramidal-oblong, $4 \frac{1}{2} 2^{-8}$ in (12$20 \mathrm{~cm}$ ) long, open, the branches whorled, spreading but somewhat contracted at maturity; spikelets about 2 mm long. Introduced from Europe.

Distribution and habitat: Redtop, or meadow redtop, has become common in California. It is more widely distributed than creeping bent, and occurs throughout the Coast and Sierra ranges up to $8000 \mathrm{ft}$. Redtop grows best on rich, sandy, or clay loams, but does well on a variety of soils whenever sufficient moisture is available. Intolerant of shade, it rarely grows in timber but is common in meadows, open parks, and along stream banks. Redtop stands do well on acid soil like creeping bent, but can also withstand drier areas.

Forage value and reproduction: Although somewhat less palatable than some other cultivated grasses, redtop ranks as good forage for cattle and horses, and as fairly good for sheep. On moist sites the plant remains green all summer and is grazed with moderate relish season-long. It is a common hay plant where better-liked grasses do not thrive. Although yields are high, the feeding value of redtop hay is increased when the grass is mixed with other grasses and clovers. Good reproduction is assured by heavy seed crops and strong rhizomes.

\section{CREEPING BENT (Agrostis palustris)} produces long stolons in suitable situations, or dense mats among other vegetation; panicles narrow, rather dense, $2-4$ in $(5-10 \mathrm{~cm})$ long; spikelets about $2 \mathrm{~mm}$ long. Introduced from Europe. (Fig. 75.)

Distribution and habitat: Now naturalized on many ranges in northern California, creeping bent is common on tidelands and along sloughs in the coastal

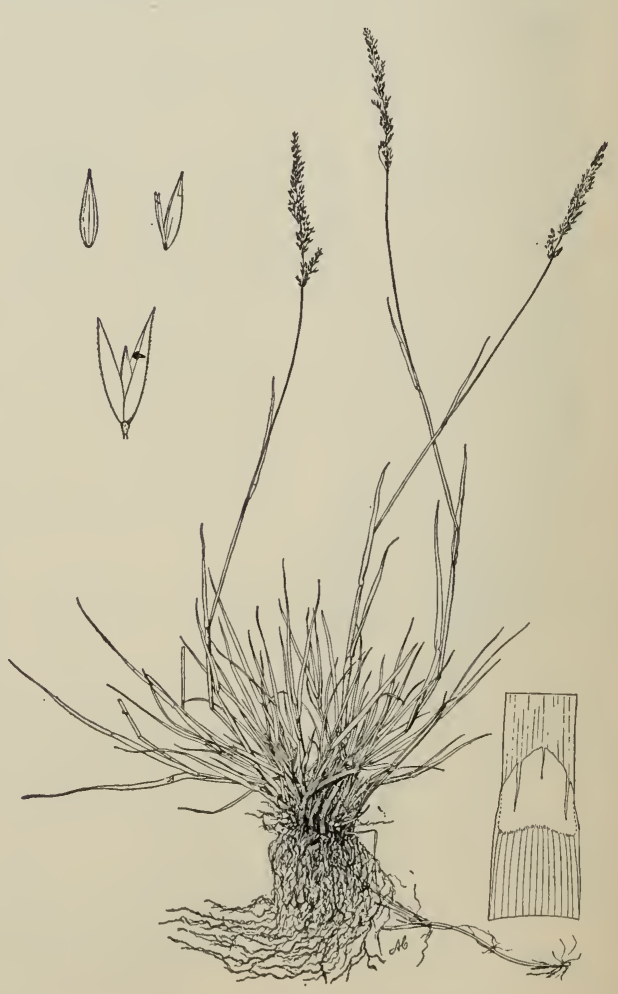

Fig. 75. Creeping bent (Agrostis palustris). 
counties, while in the interior it occurs mostly along ditches and on wet meadows up to $8000 \mathrm{ft}$. Established stands endure infrequent overflows and continued partial submersion in water, but the species also does well on subirrigated sites that become dry for short periods in the summer. Creeping bent thrives on rich, peaty soils, even on those too acid for many other lawn or forage plants.

Forage value and reproduction: When young, creeping bent produces abundant palatable leafage. Unless stands are heavily grazed, however, the herbage soon becomes tough and unpalatable. It does not provide the choicest of hay except when mixed with more palatable grasses and legumes. Creeping bent furnishes good grazing for cattle and horses from early spring to late fall but is seldom used by sheep. Seed production is good, and the creeping stolons enable adequate maintenance of even heavily grazed stands.

\section{LEAFY REDTOP (Agrostis diegoensis)} resembles the preceding, on the average taller, blades often longer; panicle longer, narrower, the branches ascending; spikelets $3 \mathrm{~mm}$ long, the lemma awned or awnless. (Fig. 76.)

Distribution and habitat: Leafy redtop is the most abundant of the native sod-formers. It is found in moist sites from Monterey County northward along the coast, and in the northern Sierra Nevada to $7500 \mathrm{ft}$. It also occurs in the coastal mountains from Los Angeles south to San Diego.

Forage value and reproduction: Although growth is rather scattered over most of its range, the abundance of palatable leafage per plant is large. Livestock relish the herbage and the wellrooted plants withstand grazing well. The seed ripens in August in the southern part of the state, and in September at the higher elevations in northern California.

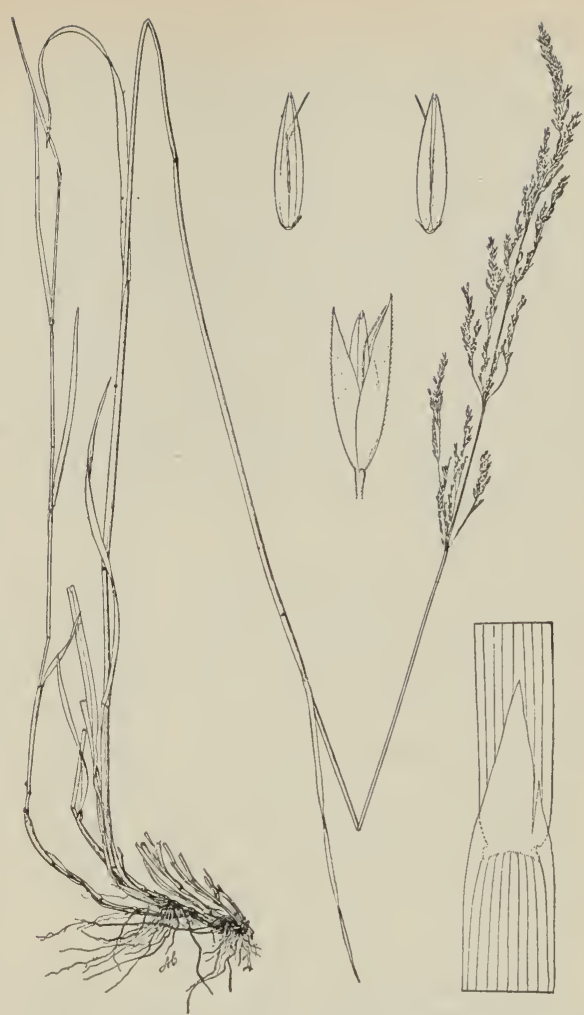

Fig. 76. Leafy redtop (Agrostis diegoensis).

5. HALL'S REDTOP (Agrostis hallii) is much like leafy redtop, on the average not so tall, the panicle commonly more lax, chiefly distinguished by the conspicuous hairs at the base of floret.

Distribution of Hall's redtop is mostly in woods near the coast, from Santa Barbara County northwards into Oregon. The forage rating is similar to that of leafy redtop.

6. MOUNTAIN REDTOP (Agrostis variabilis) forms small dense tufts; culms slender, 4-10 in $(10-25 \mathrm{~cm})$ tall, with soft fine basal foliage; panicles narrow, rather dense, $1-31 / 2$ in $(2.5-9 \mathrm{~cm})$ long, usually purple, spikelets about $2 \mathrm{~mm}$ long.

As the name indicates, mountain redtop is important only at high altitudes. It occurs in the Hudsonian and AlpineArctic life zones of the High Sierra and 
other mountains in northern California, mostly above $6000 \mathrm{ft}$. Moist soil is required for good development. The fine, basal leafage is palatable to all livestock.

7. TICKLEGRASS (Agrostis scabra) grows in dense small tufts; culms mostly $1-2 \frac{1}{2}$ $\mathrm{ft}(30-75 \mathrm{~cm})$ tall with fine basal foliage; panicles mostly $6-10$ in (15-25 cm) long and nearly as wide, sometimes larger, the elongate very slender scabrous brittle branches dividing and spikeletbearing towards the ends; spikelets about $2.5 \mathrm{~mm}$ long.

Distribution and habitat: Ticklegrass distribution in California is limited to the northeast, and in the Sierra Nevada up to $12,000 \mathrm{ft}$. It is characteristic of the cooler and higher range areas where it is moderately abundant in meadows, along streams, and in dry to moist, open woodlands. Being intermediate in succession of the herbaceous cover, ticklegrass grows on scablands, burned-over areas, and on moist denuded sites.

Forage value and reproduction:Ticklegrass is well liked when young, but is little utilized after heading out. Elk graze upon the grass in winter, but the large panicles with elongate very fine, rough, brittle branches are objectionable to domestic livestock, and discourage use of the fine short leaves (10). At seed maturity, in August and September, the broad panicle sometimes breaks away and is carried by the wind like a tumbleweed $(20)$.

\section{NEEDLEGRASSES (STIPA)}

Needlegrasses, also simply referred to as stipas in California, are tall tufted perennials, mostly with rather fine foliage; panicles mostly long and narrow; spikelets narrow, the glumes often papery,

${ }^{4}$ Members of the Division of Agronomy, and a few other Californians, prefer "stipa" as the common name for species of the genus Stipa. They feel that "needlegrass" may cause confusion with ripgut (Bromus rigidus) by some stockmen. The authors prefer "needlegrass" because it is the all-western common name and appears extensively in the literature. acuminate; floret nearly cylindric with a sharp, bearded callus at base; lemma indurate, convolute, the margins overlapping, bearing a prominent awn, the junction of body and awn evident, usually marked by a crown of short hairs, the awn twisted below, geniculate, persistent.

There are 20 needlegrasses in California. All are perennials, but only seven species are plentiful enough to contribute appreciably to the forage crop.

Needlegrasses are widely distributed throughout the state (figs. 77, 78), and grow from sea level to $10,000 \mathrm{ft}$. Stands are most abundant on the foothill and valley ranges of central and southern California at intermediate elevations. They usually occur on open slopes or in thin stands of timber and brush. Although adapted to a variety of well drained soils, needlegrasses attain maximum density and growth on clay and sandy loams. They are high in the succession of plant cover, and follow brome grasses, fescues, and bluegrasses in invasion and establishment on disturbed areas. Decline in the importance of needlegrasses is not surprising when it is

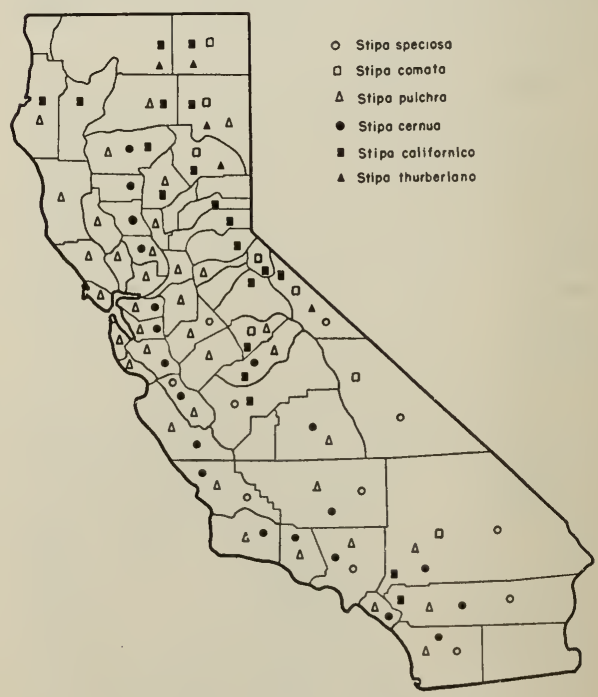

Fig. 77. Distribution of needlegrasses (Stipa spp.). 


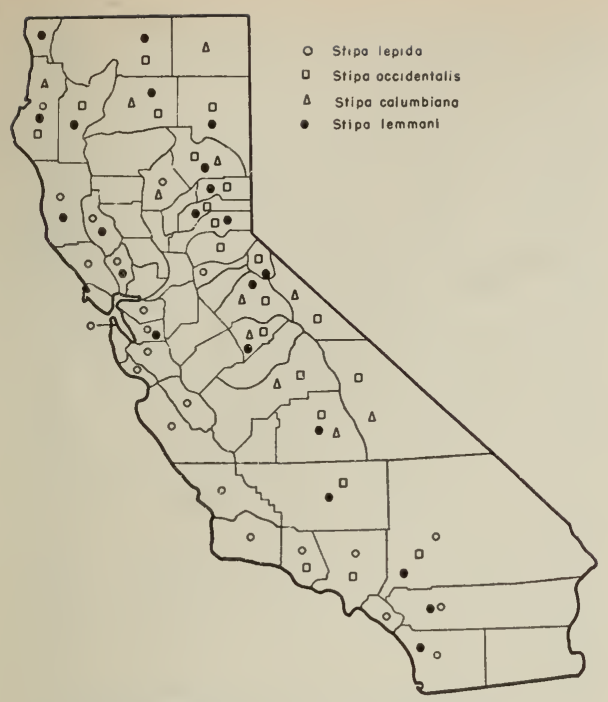

Fig. 78. Distribution of needlegrasses (Stipa spp.).

realized that areas where they formerly abounded are now principally occupied by the state's large agricultural industry (2).

As a group, needlegrasses are leafy bunchgrasses which rank as good forage. for sheep and good to choice for cattle and horses. The mature herbage is inclined to be fibrous and tough, but the basal leafage remains green over a long growing period and cures well on the ground. Needlegrasses are valuable for late fall and winter grazing on the coast ranges, where they remain succulent for as long as nine or ten months (53). In the interior valley and foothill areas they dry almost as early as do the bulk of the annual species (61). On the foothill ranges, bromes, fescues, and other annuals generally furnish much of the palatable winter feed, but the needlegrasses are grazed closely when the herbage is young, and during periods of drought when annuals supply relatively little forage. Needlegrasses are reportedly equivalent to timothy in protein and nitrogenfree extract content, but are somewhat higher in fiber (23). The sharp-pointed seeds are occasionally troublesome. They sometimes work into the tissues of the mouth, tongue, and ears of domesitc livestock and game animals. As the seeds are cast soon after maturity, however, the troublesome period is rather short.

Moderately grazed stands produce large viable seed crops maturing between June and August. Seeds are planted by the alternate twisting and untwisting action of the long awns during dry and wet weather. This self-planting mechanism helps to maintain properly managed stands and adds to the aggressive-

\section{Key to Species}

Awn once bent; first segment of awn long plumose, the hairs 5-8 $\mathrm{mm}$ long

8. S. speciosa

Awn twice bent; first segment of awn shortplumose or scabrous

Lemma appressed-villous with white hairs Culms robust, 3-6 ft (1-2 m) tall; panicle rather thick, purplish 11. S. coronata Culms slender, mostly not more than $3 \frac{1}{4}$ $\mathrm{ft}(1 \mathrm{~m})$ tall; panicle slender, pale

Hairs towards summit of lemma much longer than those below

6. S. californica

Hairs short all over the lemma

5. S. occidentalis

Lemmas not villous, short-pubescent or partly glabrous

Awn very slender and flexuous, $10-15 \mathrm{~cm}$ long

7. S. comata

Awn stouter, distinctly bent

Awn short-plumose below; ligule 3-6 $\mathrm{mm}$ long

9. S. thurberiana

Awn scabrous only; ligule 1-2 mm long

Panicle open, drooping or nodding Lemma 8-10 mm long

Floret fusiform; awn 4-6 cm long

1. S. pulchra

Floret cylindric; awn 6-11 cm long

2. S. cernua

Lemma $6 \mathrm{~mm}$ long 3. S. lepida

Panicle narrow, erect or nearly so Glumes broad; floret fusiform

10. S. lemmoni

Glumes narrow, thin, floret slender 4. S. columbiana 
ness of needlegrasses on the range. They sometimes increase considerably on freshly burned chaparral lands. They are recommended for artificial reseeding of brush-cleared California ranges (36). Seed is not yet commercially available.

\section{PURPLE NEEDLEGRASS (Stipa pulchra)} is densely tufted, the culms $2-31 / 4 \mathrm{ft}$ $(60-100 \mathrm{~cm})$ tall; leafy at base; panicle 6-8 in (15-20 cm) long, nodding; spikelets purplish; lemma dark, nearly glabrous except at base and summit. (Fig. 79.)

Distribution and habitat: Purple needlegrass is found in the Coast Range

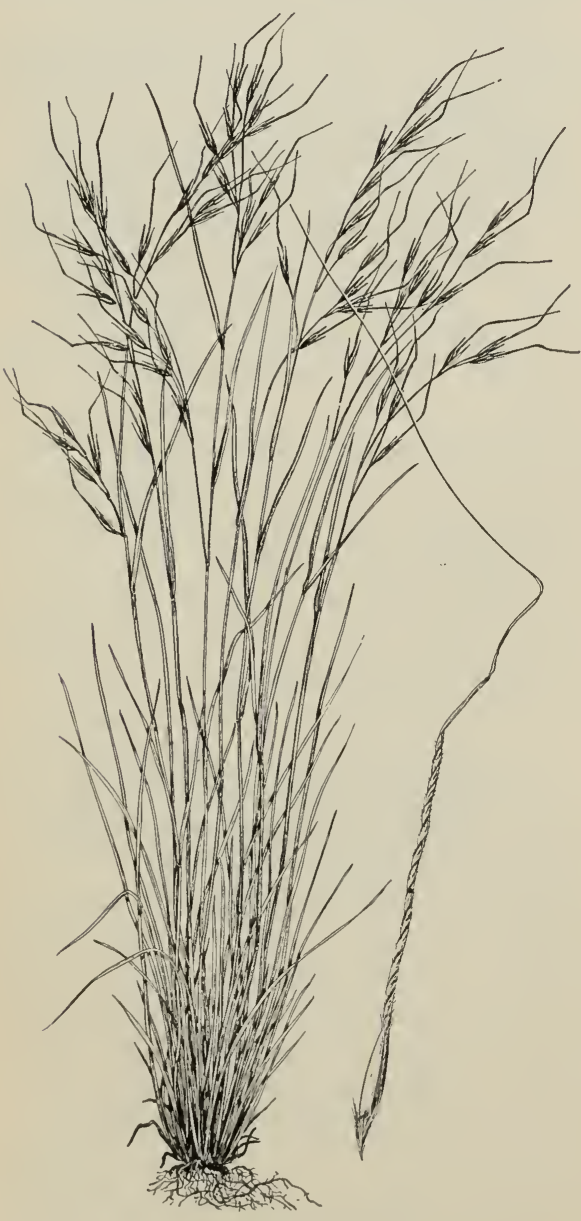

Fig. 79. Purple needlegrass (Stipa pulchra). from Humboldt County south to San Diego County, and in the Sacramento and San Joaquin valleys, mostly below $3000 \mathrm{ft}$. It is most abundant in the Coast Range where it inhabits the warmer slopes, open well-drained flats, and sparsely timbered areas of the foothills and valleys. Purple needlegrass is high in the successional stage of plant cover. Under proper management it usually replaces bromegrasses, some fescues, and annuals. Although adapted to many sites, the most persistent and dense stands are found on sandy loams.

Forage value and reproduction: Purple needlegrass is grazed with relish over a long growing period in the Coast Range. In this region the large amount of basal leafage remains green for nine or ten months and is cropped by all classes of livestock. In the interior valleys growth is less succulent and the roughish leafage is grazed only in early spring or in times of drought, and then chiefly by cattle and horses. The production of purple needlegrass on the foothill ranges has been reduced by improper grazing practices. Heavy grazing during the period of maximum growth, usually during May, has apparently prevented storage of adequate food reserves in stem bases and roots, and consequently reduced growth the subsequent year (53). A management plan designed to favor this grass should include a rotation to obtain light stocking, in alternation with complete rest, during the intervals of rapid growth. Seed habits are strong and the mature crop is cast in early summer.

2. NODDING NEEDLEGRASS (Stipa cer$n u a)$ is similar to purple needlegrass $(S$. pulchra) but is more slender, usually more leafy at base; panicle about $1 / 3$ the entire length of the plant, drooping; lemma cylindric, the awn longer, more flexuous.

Distribution and habitat: Nodding needlegrass closely resembles purple needlegrass, and was only recently segre- 
gated from the latter as a distinct species (56). When the two grow together as they frequently do, notably in Glenn County and in the southern Coast Range, nodding needlegrass is easily distinguished by its lighter color, narrower leaves, and more slender flower stalks and spikelets. It occurs chiefly in the San Joaquin and Sacramento valleys, the valleys of southern California, and on the edges of deserts. It is more droughtresistant than purple needlegrass.

Forage value and reproduction: The fine leaves of nodding needlegrass are readily taken by livestock. In the interior valleys it matures early and the grazing season is normally short. The dry leafage is grazed some, however, in times of drought when other forage is scarce. The vigorous seed habits are similar to those of purple needlegrass.

3. FOOTHILL NEEDLEGRASS (Stipa lep$i d a)$ is densely tufted and leafy at base; culms 2 to $3 \frac{1}{4} \mathrm{ft}(60-100 \mathrm{~cm})$ tall; panicle loose and open, drooping, 6-8 in (15-20 cm) long, sometimes longer, the branches distant; lemma about $6 \mathrm{~mm}$ long, dark, sparsely pubescent with white hairs; awn 2.5-4 cm long.

Distribution and habitat: Foothill needlegrass is principally a plant of the Coast Range from Humboldt County south to San Diego County. It is also found on the Sierra Nevada foothills in the upper San Joaquin Valley. It grows from sea level up to timbered areas, and commonly occurs with oakbrush and melicgrasses on sandy soils of granitic origin.

Forage value and reproduction: The fine basal leafage of foothill needlegrass is grazed with much relish throughout the season, and remains green and palatable after the annual vegetation has dried. This grass withstands much shading and if present in brush stands, makes rapid growth after a fire (36). Seed is cast in June, and stands respond favorably to grazing management.
4. COLUMBIA NEEDLEGRASS (Stipa columbiana), sometimes called small needlegrass or porcupine grass, grows in dense leafy tufts with few culms to the tuft, the culms $15-25$ in $(40-65 \mathrm{~cm})$ tall; panicle 4-8 in (10-20 cm) long, narrow, rather dense, purplish; lemma 6-7 mm long, pubescent, awn 2-2.5 cm long.

Distribution and habitat: Columbia needlegrass grows most commonly in the Sierra Nevada between about 7000 and 10,000 ft. Drought-enduring, it inhabits dry soils of open woodland types, and is often associated with bluegrasses and with other subalpine grasses or weeds.

Forage value and reproduction: The foliage of Columbia needlegrass is relished throughout the foraging season. Because of its fine, soft-leaved herbage, sheep graze this grass more closely than any other needlegrass. A plentiful seed crop ripens in August and September. Adequate reproduction of most stands is secured, especially on sheep ranges where the seeds, although not troublesome, are usually left to mature (10). In the Intermountain Region Columbia needlegrass (porcupine grass) is an important species of the porcupine grassyellowbrush consociation. Next to the wheatgrass-dominated stand it constitutes the highest and most stable type, and is probably the better of the two as a forage producer considering all classes of livestock (49).

\section{WESTERN NEEDLEGRASS (Stipa occi-} dentalis) grows in small tufts with a mass of fine foliage at base; culms mostly $10-15$ in $(25-40 \mathrm{~cm})$ tall; panicle narrow but loose, 4-8 in (10-20 cm) long, pale; lemma and awn finely whitepubescent.

Distribution and habitat: Western needlegrass is common in the Sierra Nevada from 3000 to $11,000 \mathrm{ft}$. Although usually occurring in scattered clumps it occasionally forms the most conspicuous 
vegetation on hillsides or ridgetops in open timber. With its deeply penetrating root system western needlegrass withstands drought better, especially in the seedling stage, than do most species (48).

Forage value and reproduction: Foliage of western needlegrass ranks as good forage for all classes of livestock. The early growth is highly palatable, but the mature leafage is somewhat tough for sheep. As it matures late, its forage value is high in the fall when other grasses have dried. Reproduction is good from a seed crop that ripens in July and August, but stands are not as aggressive as those of some other needlegrasses.

\section{CALIFORNIA NEEDLEGRASS (Stipa} californica) is usually $1 \mathrm{~m}$ or taller, with elongate flat to involute blades; panicle narrow, to $40 \mathrm{~cm}$ long, pale and shining, lemmas pale, loosely white-villous.

This grass occupies open woods and dry rocky sites from the San Jacinto Mountains, and in the Sierra Nevada from Nevada County to Mariposa County and northward into Oregon. (Fig. 77.) Its elevational range is from 4000 to 10,000 $\mathrm{ft}$. Herbage is palatable to all livestock, but its use is restricted due to the relatively short season of mountain grazing.

\section{NEEDLE-AND-THREAD (Stipa comata)} also grows in dense clumps, culms 2-3 ft $(60-90 \mathrm{~cm})$ tall, with abundant fine but rough basal foliage; panicle loose, pale, $1 / 3-1 / 2$ the entire height of the plant; lemma pale, 8-12 $\mathrm{mm}$ long, the slender awn loosely curly.

Distribution and habitat: Needle-andthread is essentially confined to the east slope of the Sierra Nevada, where the stand is generally scattered. It grows up to about $8000 \mathrm{ft}$. At low altitudes it occurs on semidesert plains and foothills, and in the mountains grows on dry, sandy soils in the ponderosa pine belt of the Transition life zone.

Forage value and reproduction:
Needle-and-thread is valuable spring forage. It begins growth early while many other grasses are still dry, and greens up after rains come in the fall. Early growth is relished by all classes of stock, and cattle and horses graze the green growth after advent of autumn rains. The hard, sharp florets of mature plants are objectionable to stock, especially sheep, but not for long as the seeds drop as they ripen. A fair seed crop is produced under moderate grazing. Unprotected stands decline rapidly, however, from lack of reproduction.

\section{DESERT NEEDLEGRASS (Stipa speci-} osa) grows in large dense clumps, the culms $1-1 \frac{1}{2} \mathrm{ft}(30-45 \mathrm{~cm})$ tall, with elongate involute blades, often falling from the old brown basal sheaths; panicle narrow, 4-6 in (10-15 cm) long, the plumose lower segment of awn conspicuous.

Distribution and habitat: As the name implies, desert needlegrass grows in arid regions of southern California. It is most abundant in the Mojave Desert and the area east of the Sierra Nevada north to Mono County. It occurs on dry, sandy or gravelly soils up to $6000 \mathrm{ft}$, where it is frequently associated with oaks and sagebrush.

Forage value and reproduction: Desert needlegrass is a compact bunchgrass with considerable basal leafage. The young herbage is palatable to all classes of livestock. When mature the fine basal leaves, intermingled with the coarse stems and flowering stalks, are grazed some by cattle and horses, but little by sheep. A seed crop of fair size matures in May and June.

\section{THURBER'S NEEDLEGRASS (Stipa thur-} beriana) is densely tufted with a mass of scabrous to puberulent filiform leaves at base; panicles 8 to $15 \mathrm{~cm}$ long, the awns white-plumose.

This grass occupies open woods and dry rocky areas in the mountains from 
Mono County northward. (Fig. 77.) The abundant basal leafage provides considerable forage per plant, but the stand is seldom dense.

10. LEMMON NEEDLEGRASS (Stipa lemmoni) is densely tufted with mostly short subfiliform basal foliage, the culm blades to $2 \mathrm{~mm}$ wide; panicle narrow, mostly 10-12 cm long, pale to purplish; spikelets relatively plump, the glumes broad, the lemma fusiform.

Distribution and habitat: Lemmon needlegrass grows at intermediate and high elevations on the mountains and foothills of San Diego County and in the Sierra Nevada from Mariposa County to Siskiyou County. (Fig. 78.) It frequently occupies barren rocky well-drained soils of open woods and plains. The forage yield per plant is moderately large but the stand is seldom dense. Nevertheless the fine basal herbage contributes a considerable amount of choice forage which is sought by all kinds of livestock.

\section{LARGE NEEDLEGRASS (Stipa coro-} nata) is the largest of the California needlegrasses, robust and 1-2 meters tall; blades elongate with scabrous involute tips; panicle contracted, rather dense, 30-40 cm long; lemmas clothed with long white hairs extending into a silky white brush at the apex; awn 4-5 cm long.

Large needlegrass occupies open ground on the coastal range from San Mateo County southward into Lower California. The coarse, rather harsh herbage is grazed limitedly by cattle, but cropped most closely by horses and burros.

\section{REEDGRASSES (CALAMAGROSTIS)}

Reedgrasses are leafy perennials in tufts or with rhizomes, the culms simple, not branching; panicles narrow and dense to open; spikelets small, the glumes longer than the florets; lemma awned from the back, hairy on the callus; rachilla prolonged behind the palea as a minute hairy bristle.

Twelve perennial reedgrasses grow naturally on California range lands, but only four are important forage grasses. (Fig. 80.) The other eight species are either of scattered occurrence or limited distribution.

Reedgrasses enjoy a wide elevational range, occurring in scattered stands from sea level along the coast to alpine meadows in the Sierra Nevada. The moisture requirements of different species vary considerably. Some grow on wet acid sites, whereas others are adapted to dry or saline situations (10). They usually grow best on moist soils in open timber stands. On dry sites reedgrasses are frequently associated with fescues and bluegrasses, but in wet meadows they mingle with sedges, rushes, and redtops.

Reedgrasses are generally classed as fillers. Some species, however, where locally abundant, furnish the bulk of early forage on mountain ranges. All classes of livestock graze the young growth with moderate relish, but cattle make better use of the herbage than

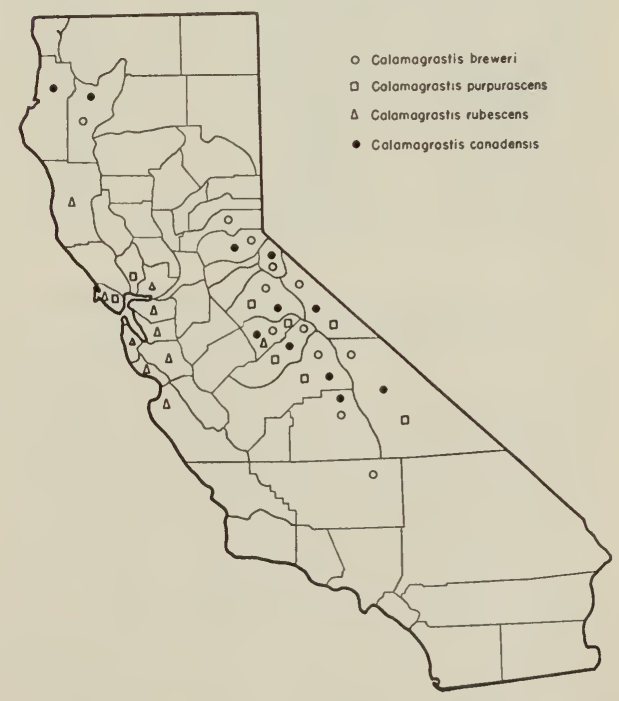

Fig. 80. Distribution of reedgrasses (Calamagrostis spp.). 
sheep. As the season advances reedgrass herbage becomes harsh and tough, and is eaten little where more tender herbage is available. Big game animals consume appreciable amounts. Elk graze several species moderately; deer to a lesser extent. Reedgrasses are not as a rule strong seed producers, but the limited seed crop that fully matures usually germinates well.

The reedgrasses important on California range lands are pine reedgrass and bluejoint among the sod-formers, and Brewer reedgrass and purple reedgrass of the bunch habit of growth.

\section{Key to Species}

Panicle open, the branches spreading

Plants without rhizomes, densely tufted, the blades capillary

1. C. breweri

Plants with creeping rhizomes; blades flat, to 4-8 $\mathrm{mm}$ wide

4. C. canadensis

Panicle narrow, dense or somewhat loose

Glumes 6-8 mm long; awn of lemma exceeding the glumes; panicle purplish; collar of sheath glabrous

2. C. purpurascens

Glumes 4-5 mm long; awn of lemma shorter, exserted from side of glumes; collar of sheath pubescent, sometimes obscurely so

3. C. rubescens

1. BREWER REEDGRASS (Calamagrostis breweri) is densely tufted with a mass of fine foliage at base; culms slender, 6-12 in $(15-30 \mathrm{~cm})$ tall; panicle very open, few-flowered, $1 \frac{1}{2}-3$ in $(3-8 \mathrm{~cm})$ long; spikelets 3-4 $\mathrm{mm}$ long, purple, the geniculate awn exceeding the glumes. (Fig. 81.)

Distribution and habitat: Brewer reedgrass is typical of high meadow lands in the Sierra. It occurs at 7000 to 12,000 $\mathrm{ft}$ from Plumas County south to Tulare County, and is found in more scattered stands in higher north coast ranges. Though seldom forming pure stands, it is sometimes the dominant species in moist, open, or partly shaded sites.

Forage value and reproduction: The fine leafage is highly palatable to all classes of livestock and is well liked by deer. Succulent forage is produced

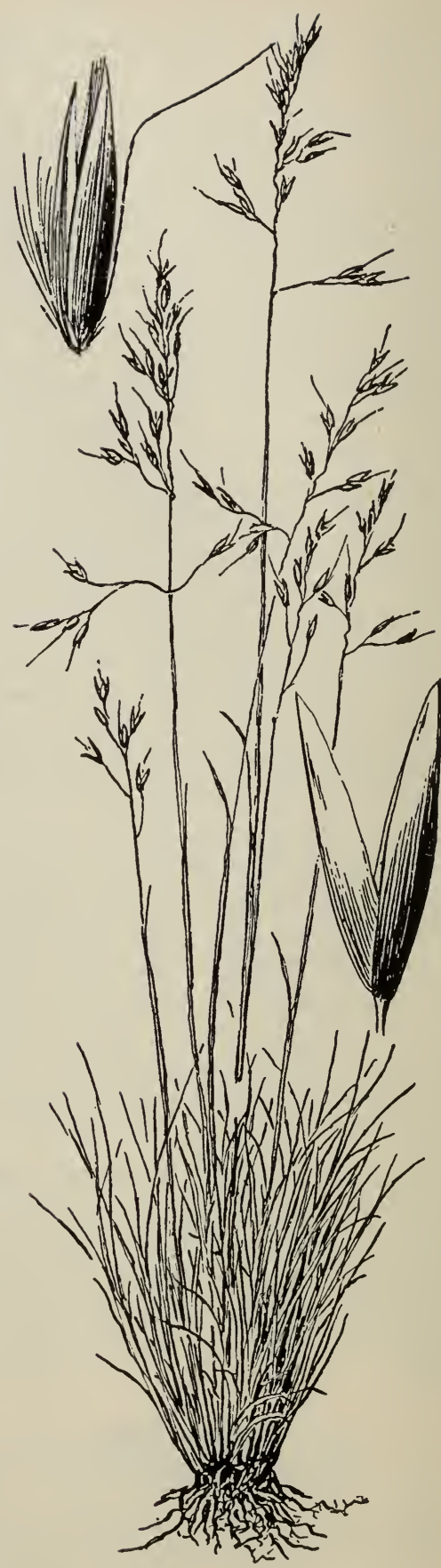

Fig. 81. Brewer reedgrass (Calamagrostis breweri). 
throughout the summer grazing season. It is the most valuable species of the socalled "shorthair" ranges of the high Sierra, where it is commonly associated with shorthair sedge (Carex exserta) and other subalpine and alpine plants. The moderate seed crop matures unevenly and is scattered from early August until well into September.

2. PURPLE REEDGRASS (Calamagrostis purpurascens) is densely tufted (sometimes with short rhizomes); culms 1530 in $(40-75 \mathrm{~cm})$ tall; foliage rough, blades $2-4 \mathrm{~mm}$ wide; panicles narrow, dense, 3-6 in (7-15 cm) long, purplish or pinkish, the awns rather prominent. (Fig. 82.)

Distribution and habitat: Purple reedgrass grows sparingly over the Sierra Nevada, but becomes abundant in the vicinity of Yosemite National Park and Mt. Whitney at altitudes above 10,000 $\mathrm{ft}$. It does well on rocky outcrops and poor granitic soils where moisture is limited.

Forage value and reproduction: In the spring the herbage is readily taken by all livestock, but by midsummer it is grazed with moderate relish only by cattle and horses. Purple reedgrass is a bunchgrass and depends on seed for reproduction. Considering the altitude at which it grows, fair seed crops are produced.

3. PINE REEDGRASS (Calamagrostis rubescens) grows in rather small tufts, producing numerous short rhizomes; foliage softer than in the preceding, the lower sheaths mostly purple; panicle narrow, $3-6$ in $(7-15 \mathrm{~cm})$ long, dense or sometimes slightly open, pale or purplishtinged. (Fig. 83.)

Distribution and habitat: Because of its common association with ponderosa pine, pine reedgrass is also called pinegrass. In California it is most abundant in the Coast Range from Monterey County northward into Oregon. It ranges from

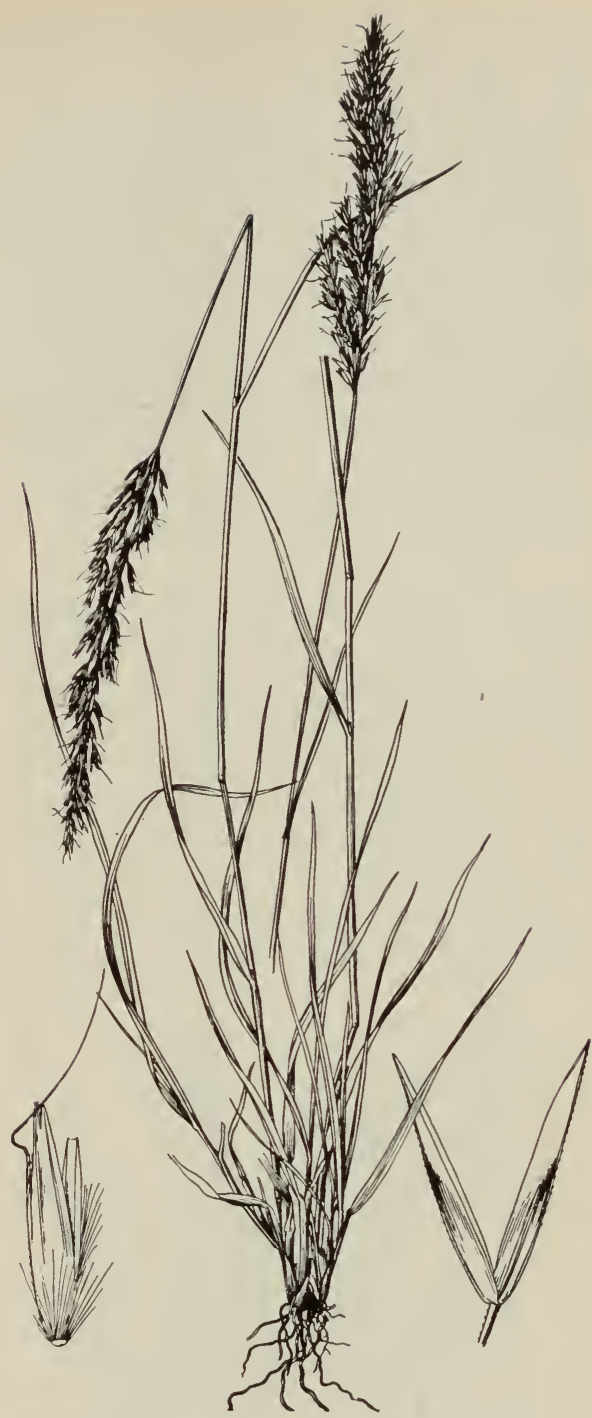

Fig. 82. Purple reedgrass (Calamagrostis purpurascens).

sea level along the coast to $10,000 \mathrm{ft}$ in the Sierra, where it is not very plentiful. Although usually found on well-drained soils, the creeping rhizomes and deepfeeding roots of the plant permit establishment of stands on droughty sites as well.

Forage value and reproduction: The forage value of pine reedgrass varies with the season. Early growth is relished 
by all stock, and where pastured heavily the leafage is taken well into the summer. When the plant begins to mature and seed stalks appear, the harsh fibrous leafage is not attractive to grazing animals. Both game animals and domestic stock take some of the foliage in the fall after it is softened by rains. Comparatively few flower stalks are produced, but the limited seed crop which matures in late summer germinates well. With their strong rhizomes, stands of pine reedgrass withstand heavy grazing and are valuable for watershed protection.

4. BLUEJOINT (Calamagrostis canadensis) is rather coarse, with numerous creeping rhizomes; culms 2-4 ft (60$120 \mathrm{~cm}$ ) tall, leafy, the blades to $6-8 \mathrm{~mm}$ wide; panicle pale, lax, 4-8 in (10-20 $\mathrm{cm}$ ) long, the slender branches spreading or ascending; spikelets about $4 \mathrm{~mm}$ long. (Fig. 84.)

Distribution and habitat: Bluejoint, also called bluejoint reedgrass, is a ro-

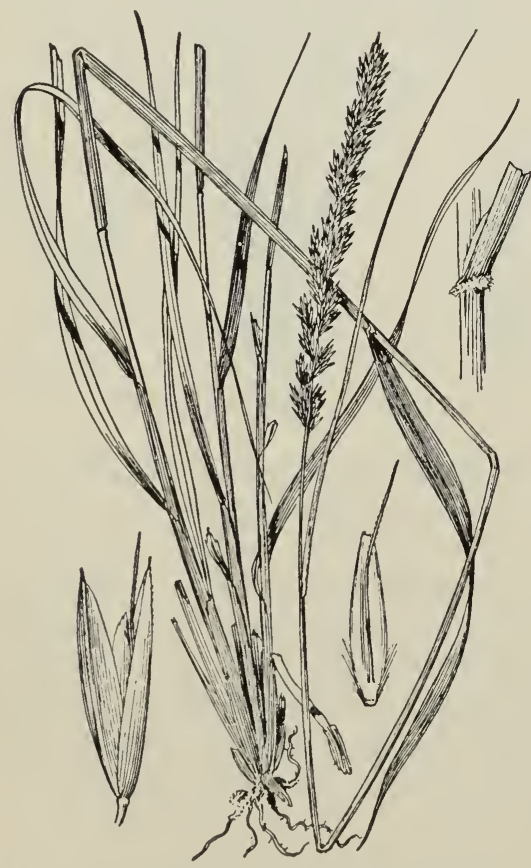

Fig. 83. Pine reedgrass (Calamagrostis rubescens).

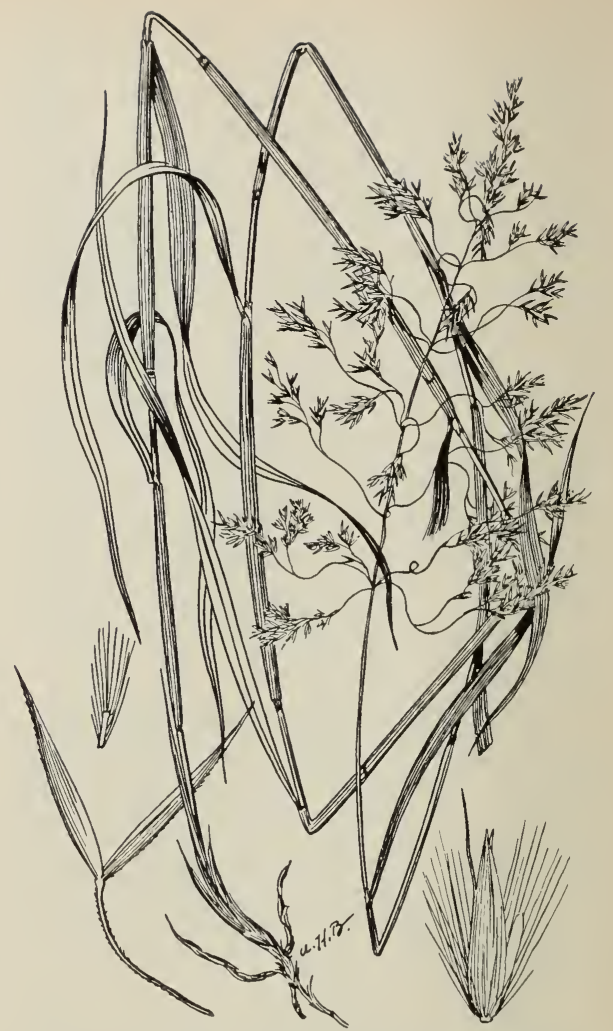

Fig. 84. Bluejoint (Calamagrostis canadensis).

bust sod-former that grows in open parks on wet soil in the Sierra Nevada and less abundantly in Trinity, Siskiyou, Shasta, and Mendocino counties of northern California. It is a marsh grass, occupying undrained meadows, swamps, and stream banks between 4000 and 10; $000 \mathrm{ft}$.

Forage value and reproduction: $\mathrm{Al}$ though palatable to all stock when young, bluejoint grows in habitats too wet for sheep until the herbage has become tough and undesirable. Cattle and horses graze the leafage throughout the season, but leave the coarse flower stalks. The species is considered good elk feed and is grazed lightly by deer (10). A good seed crop of high viability ripens in August or September. Stands are bountifully reproduced by both seeds and rhizomes. 


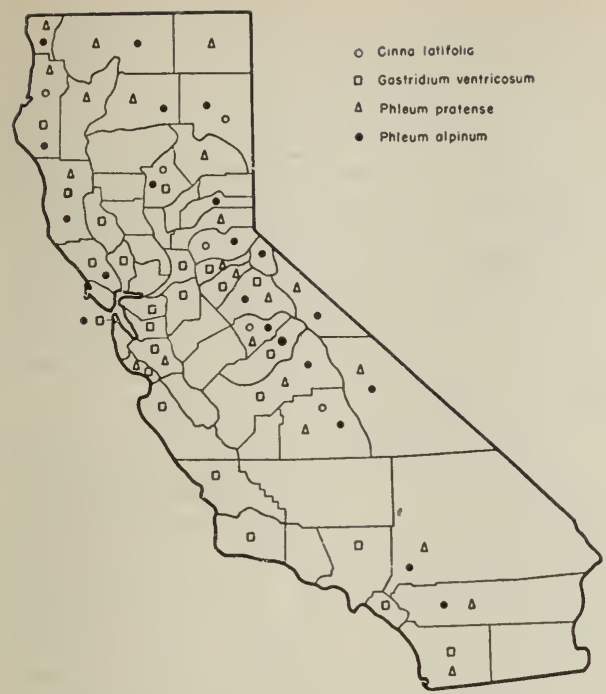

Fig. 85. Distribution of common timothy (Phleum pratense), alpine timothy (P. alpinum), drooping woodreed (Cinna latifolia), and nitgrass (Gastridium ventricosum).

\section{TIMOTHY (PHLEUM)}

Alpine timothy and common timothy are both found on California ranges. (Fig. 85.) They are densely tufted leafy perennials with flat blades and dense ovoid or cylindric panicles; spikelets flat, the glumes abruptly short-awned, the floret small and round.

\section{Key to Species}

Panicle ovoid or oblong, usually not more than twice as long as wide

1. P. alpinum

Panicle cylindric, several times longer than wide

2.P. pratense

\section{ALPINE TIMOTHY (Phluum alpinum)} is mostly $1-1 \frac{1}{2} \mathrm{ft}(30-40 \mathrm{~cm})$ tall, the culms curved or decumbent at base; panicle 8-10 $\mathrm{mm}$ thick, rarely more than $1 \frac{1}{2}$ in $(4 \mathrm{~cm})$ long, commonly shorter, bristly. (Fig. 86.)

Distribution and habitat: Alpine timothy is most abundant on summer ranges in the Sierra Nevada up to altitudes of $11,000 \mathrm{ft}$. It occurs less abundantly along the coast from Marin County northward and in Siskiyou, Modoc, and Riverside counties. It typically inhabits moist, mucky soils of meadows, swales, or bogs, where it is commonly associated with redtops, bluegrasses, meadow sedges, rushes, and hairgrass. Stands are sometimes dense and nearly pure, but are more commonly scattered and of secondary importance as range forage.

Forage value and reproduction: Alpine timothy is relished by all livestock and is highly palatable to elk and deer

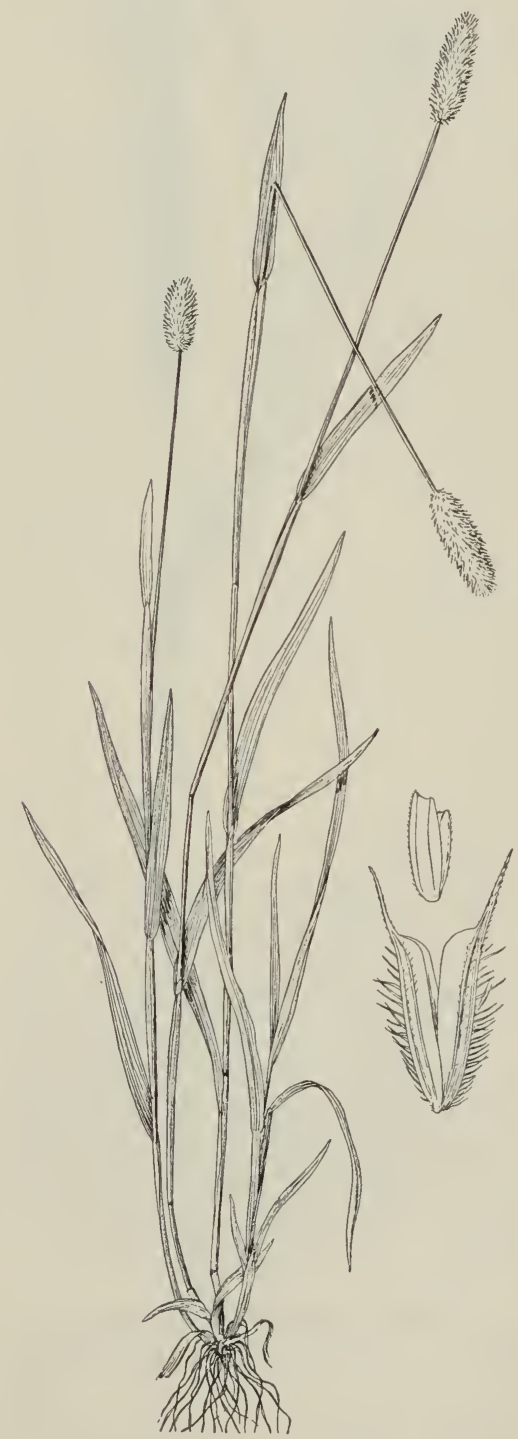

Fig. 86. Alpine timothy (Phleum alpinum) 


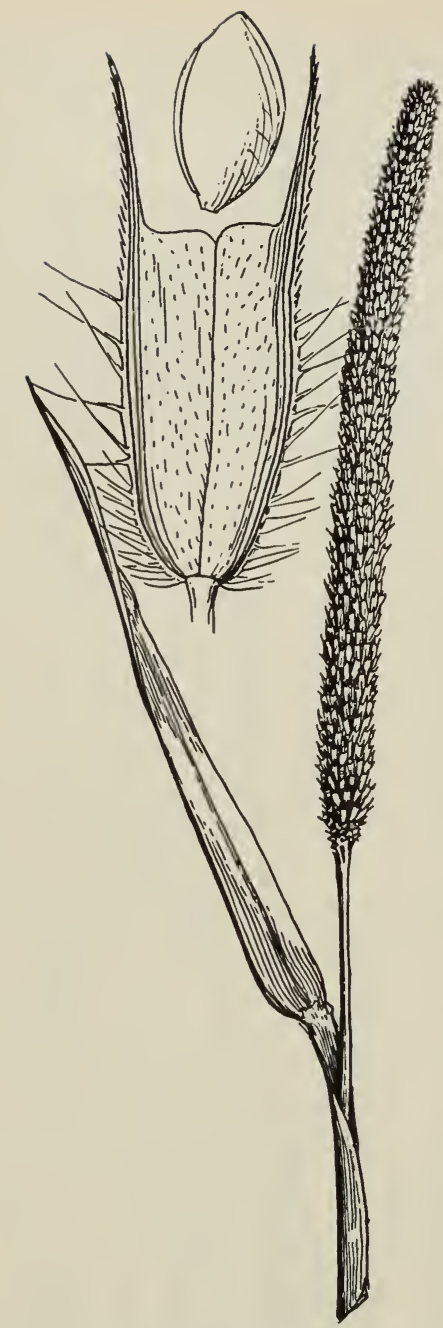

Fig. 87. Common or cultivated timothy (Phleum pratense).

(10). Early in the season sheep avoid its wet habitats but avidly graze the nutritious foliage in late summer. Stands are resistant to trampling and the species reproduces by basal shoots as well as by seed. The seed crop, highly fertile for a subalpine plant, ripens in August and September.

2. COMMON TIMOTHY (Phleum pratense) is taller, up to $3 \mathrm{ft}(90-100 \mathrm{~cm})$ tall, the culms swollen at base; blades elongate; panicle commonly $5-10 \mathrm{~cm}$ long, often longer. (Fig. 87.)
Distribution and habitat: Timothy, a cultivated species, is widely scattered on ranges throughout the state up to 9000 $\mathrm{ft}$. It competes successfully with native vegetation only where moisture and soil conditions are favorable for its growth. Although occurring on a variety of sites, it thrives best on well-drained, moist clay or loam soils. It withstands some shade and is commonly found in meadows, grassy parks, and along streams.

Forage value and reproduction: Lush, early growth of timothy is palatable to all stock. Stands in the flowering stage are commonly cut for hay, which is an ideal feed for horses, but for cattle and sheep is more desirable when mixed with clovers. If cut before full bloom, timothy hay is especially high in nutritive value. Until it reaches a height of four or five inches the plant is more palatable pasturage than Kentucky bluegrass (39). Due to its high palatability and rapid growth-stands are established the first year after planting-timothy has been used for reseeding on moist sites throughout the western range country. When seeded in mixtures with other perennial grasses, timothy is replaced in a few years by the slower-developing but longer-lived species. Except at high elevations, properly managed stands are maintained by good seed crops.

\section{MUHLYGRASSES (MUHLENBERGIA)}

Muhlygrasses are mostly perennials (a few small annuals) with narrow blades and narrow to open panicles of small spikelets; lemma 3-nerved, awned or awnless. Plants variable in habit.

Fourteen species grow rather sparsely on California ranges. Eleven are perennials and three are annuals. Of these, only four perennials and one annual are important for forage. (Fig. 88.)

Muhlies as a group are confined chiefly to the arid and desert sections in the central and southern part of the state. However, their elevational range is wide 


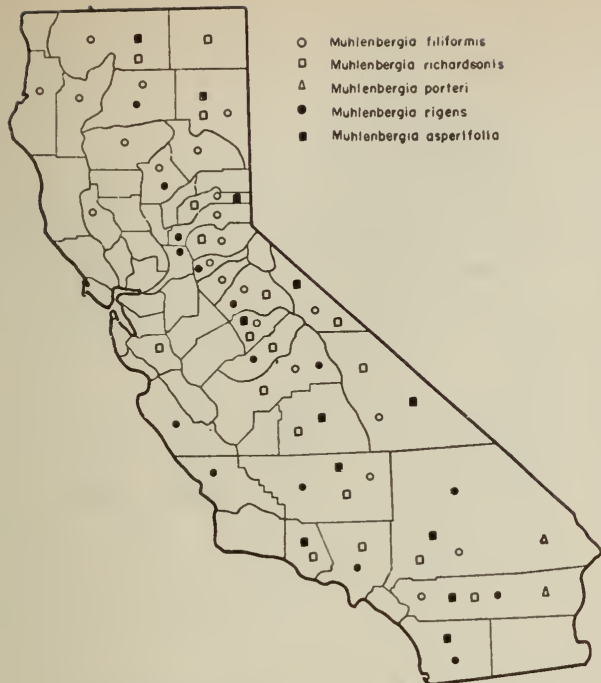

Fig. 88. Distribution of muhlygrasses (Muhlenbergia spp.).

and several species are found in the high Sierras and in northern California. They seldom grow in pure stands and are usually scattered over a wide variety of life zones and soils. For example, in the desert areas muhlies frequently occur on light sandy soils, but sometimes grow in mountain meadows on deep, heavy adobe soils. Some species grow in damp or moist sites, while others are adapted to dry, exposed hillsides.

The forage value of muhlygrasses varies greatly. Several of the more palatable ones have become seriously depleted on the arid ranges of southern California. As a whole they are most valuable for spring and summer use, for livestock graze the more matire plants only when other feed is scarce. The perennials in the early growth stages are relished by cattle and sheep alike. The tufted annuals are too short for cattle to utilize effectively, but they do contribute to the forage supply on sheep ranges. Muhlies produce fair to good seed crops that mature in August or September. Conservative grazing is needed if the former productivity of the perennial forms is to be restored on desert ranges.

\section{Key to Species}

Plants annual, in soft tufts or mats

5. M. filiformis

Plants perennial

Panicle narrow, spikelike

Plants in low tufts, with creeping scaly rhizomes; panicles not more than 4 in (10 $\mathrm{cm}$ ) long, usually shorter

1. M. richardsonis

Plants tall, without rhizomes; panicles 12 in $(30 \mathrm{~cm})$ or longer

4. M. rigens

Panicle open, the slender branches spreading Plants with slender creeping rhizomes; $\begin{array}{ll}\text { spikelets awnless } & 3 . \mathrm{M} \text {. asperifolia }\end{array}$ Plants without rhizomes; spikelets awned 2. M. porteri

1. MAT MUHLY (Muhlenbergia richardsonis), also called dwarf muhly, grows in tough bunches or mats with hard scaly rhizomes; culms nodulose-roughened, branching from the lower nodes, mostly 6-18 in (15-45 cm) long; blades commonly $1-2$ in $(2.5-5 \mathrm{~cm})$ long; panicles mostly $2-3 \frac{1}{2}$ in $(5-9 \mathrm{~cm})$ long, dense but often interrupted; spikelets $2-3 \mathrm{~mm}$ long, the glumes and lemma pointed. (Fig. 89.)

Distribution and habitat: Mat muhly, also called dwarf muhly, is most abundant in the Sierra Nevada of central and

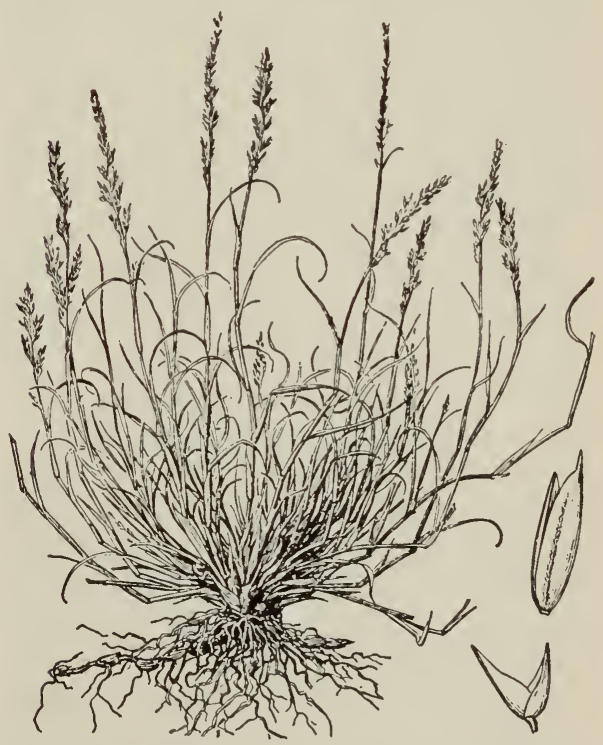

Fig. 89. Mat muhly (Muhlenbergia richardsonis). 
northern California, but is found to a lesser extent in the San Jacinto and San Bernardino mountains of southern California. The best stands occur mostly between 7000 and $10,000 \mathrm{ft}$ on sandy, gravelly, or clay loam soils, and are commonly associated with bromegrasses and wild-ryes. Mat muhly grows typically in dry meadows, parks, and open flats of the Transition and Canadian life zones, occasionally extending down into the sagebrush areas of northeastern California. Stands are usually patchy and closely matted.

Forage value and reproduction: Since the leafage becomes tough and unpalatable as the plant approaches maturity, mat muhly is grazed closely only early in the season. Cattle and horses utilize the herbage to better advantage than do sheep, but the hard stems and scant herbage are not especially attractive to stock. The rather small seed crop ripens in August and September. Stands of mat muhly nevertheless withstand heavy grazing and reproduce well, due to the sodforming habit.

\section{BUSH MUHLY (Muhlenbergia porteri)} grows in large loose masses; culms woody at base, spreading and freely branching; foliage rather sparse; panicle at maturity about as broad as long; spikelets on long delicate pedicels, purplish, the lemmas awned. (Fig. 90.)

Distribution and habitat: Bush muhly, formerly called Porter muhly, is a shrubby-looking grass occurring only in the southeastern part of California on the desert ranges. It occupies the lower plains and foothills up to some $5000 \mathrm{ft}$. Early settlers maintain that the plant was an important and abundant mesa grass in pioneers days of stock ranching (63). In contrast, present stands are scattered and found chiefly under the protection of dense shrub growth.

Forage value and reproduction: Bush muhly is palatable to all classes of stock. The coarse stems are readily eaten even

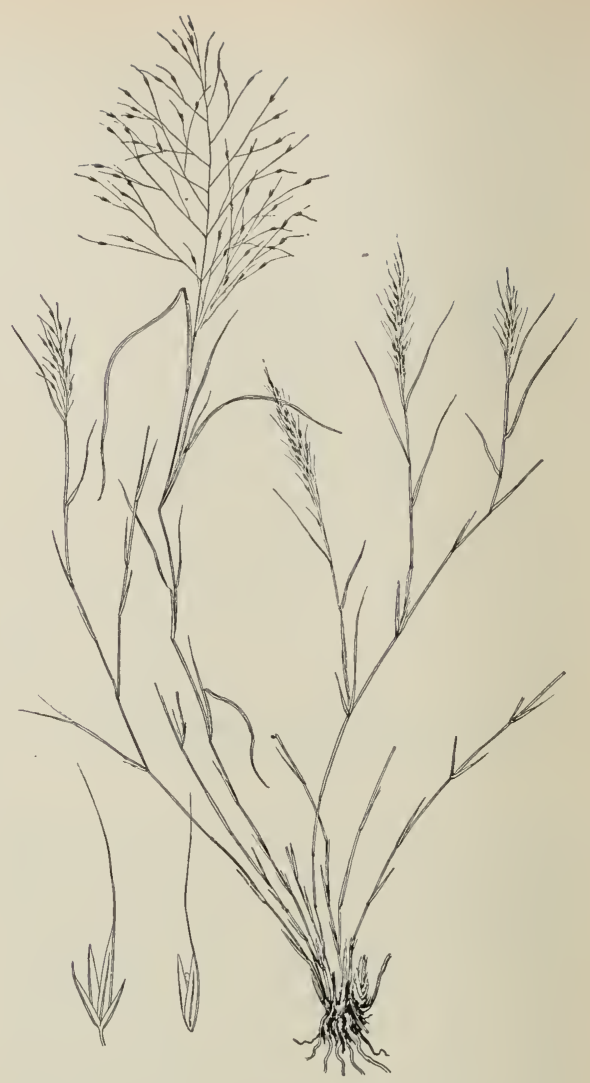

Fig. 90. Bush muhly (Muhlenbergia porteri).

in winter, and if moisture is available they remain green throughout most of the year. A seed crop of fair size ripens in July and August. Protection during early spring months is needed to favor seedling establishment.

\section{ROUGH-LEAVED DROPSEED (Muhlen-} bergia asperifolia) is low and spreading, leafy at base, with slender creeping rhizomes; culms branching at base, 6-15 in $(15-40 \mathrm{~cm})$ long; panicles large and open with fine branches, the longpediceled spikelets $1.5-2 \mathrm{~mm}$ long, the panicles breaking away at maturity, rolling as tumbleweeds.

Distribution and habitat: Roughleaved dropseed is well distributed from Siskiyou County south through the Sierra Nevada to Bakersfield. It is also found in 
the mountains of San Bernardino, Riverside, and San Diego counties. It is typical of moist, saline adobe meadows up to $7000 \mathrm{ft}$.

Forage value and reproduction: The rather fine foliage does not have high preference rating and is similar in palatability and forage value to saltgrass. It withstands heavy grazing, and reproduction by creeping runners is good.

4. DEERGRASS (Muhlenbergia rigens) is a coarse bunchgrass $2-41 / 2 \mathrm{ft}$ (90-135 $\mathrm{cm}$ ) tall, with long involute rough blades; panicles pale, slender, spikelike, up to 30 in $(60 \mathrm{~cm})$ long; spikelets about $3 \mathrm{~mm}$ long, awnless. (Fig. 91.)

Distribution and habitat: Deergrass is abundant along the coast from Monterey south to San Diego and in the foothills of the Sierra Nevada up to $5000 \mathrm{ft}$. It occu-

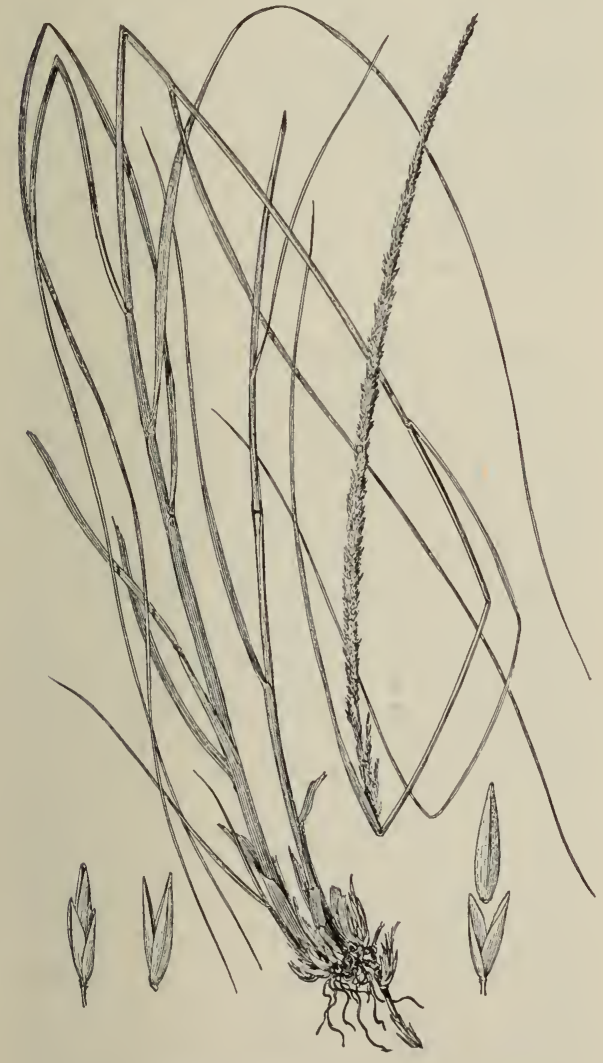

Fig. 91. Deergrass (Muhlenbergia rigens). pies well-drained, open ground or thinly timbered areas. When ample moisture is available early in the season, it forms a fairly dense cover.

Forage value and reproduction: Until the numerous coarse flower stalks are fully developed, the herbage is relished by cattle and horses and is eaten limitedly by sheep. After seed maturity the herbage is seldom grazed and is usually classed as a "filler." The mature stalks of deergrass are commonly used in basketry. Abundance of viable seed is produced in July and August.

\section{SLENDER MUHLY (Muhlenbergia fili-} formis) is a tufted annual, often forming soft mats with fine foliage; culms mostly 4-6 in $(10-15 \mathrm{~cm})$ tall, sometimes taller; panicle slender, usually not more than 2 in $(5 \mathrm{~cm})$ long; spikelets $2 \mathrm{~mm}$ long, awnless.

Distribution and habitat: Slender muhly is a mountain species of northern California, extending south as far as Tulare County in the Sierra Nevada. Stands also occur in the San Jacinto Mountains. It is early in succession and adapted to sandy, gravelly, or peaty soils of granitic origin. In moist mountain meadows it is frequently associated with sedges and rushes.

Forage value and reproduction: The short, fine leafage, interspersed with numerous flower stalks, is not highly relished by cattle or sheep. It furnishes considerable forage on the summer ranges where plentiful, and is abundantly reproduced by viable seed crops.

\section{ALKALI SACATON (SPOROBOLUS AIROIDES)}

Alkali sacaton is a coarse perennial that grows in large tough bunches; culms $20-40$ in $(50-100 \mathrm{~cm})$ tall; blades elongate, becoming involute; panicle nearly half the entire height of the plant, at maturity half to $2 / 3$ as wide as long, the stiff slender branches and branchlets widely spreading; spikelets $2-2.5 \mathrm{~mm}$ 


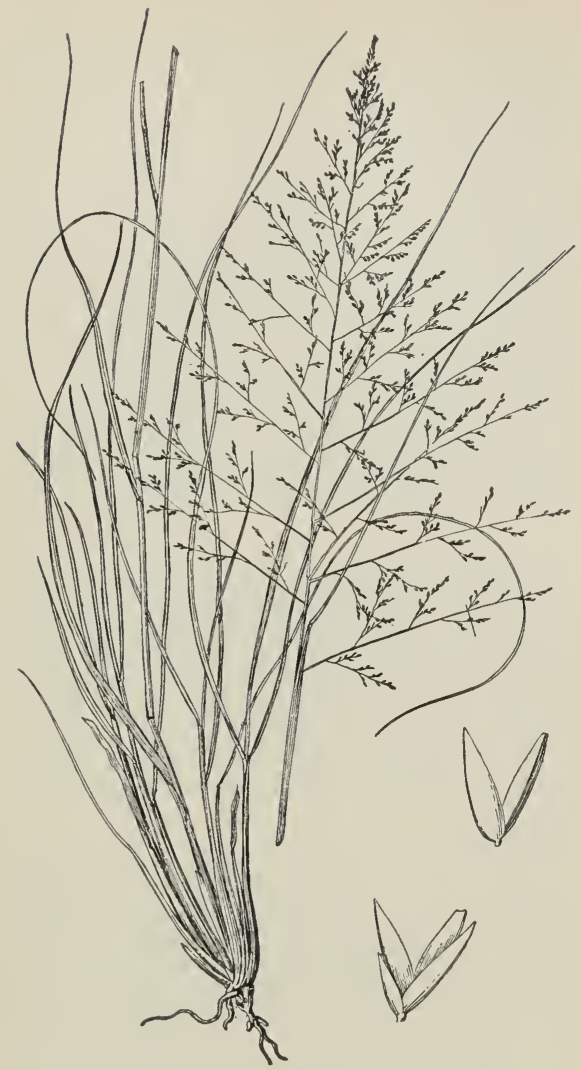

Fig. 92. Alkali sacaton (Sporobolus airoides).

long; floret plump, lemma 1-nerved; palea splitting as the grain ripens. (Fig. 92.)

Distribution and habitat: Alkali sacaton is common on alkali flats, or in dry saline soils up to $4000 \mathrm{ft}$. (Fig. 94.) In the San Joaquin Valley it is frequently associated with saltgrass. Although it thrives best on rich, slightly moist sites, it also grows on dry rocky soils of the lower benchlands.

Forage value and reproduction: Alkali sacaton is the only species of the dropseed genus important as forage on California ranges. For an alkali-enduring grass the species is high in forage value. The leafage is more palatable than that of most associated grasses, but is too coarse for sheep. Cattle graze the tender spring leafage closely, and take it throughout the season with moderate relish where it is kept cropped back and thus prevented from getting too rank and tough. Stands of alkali sacaton withstand heavy grazing well, and good seed crops provide for adequate reproduction.

\section{RICEGRASSES (ORYZOPSIS)}

Ricegrasses are perennials with long blades and open panicles; spikelets plump, the glumes broad, about equal; lemma indurate, broad, with a short, blunt, oblique callus (short-pointed in Indian ricegrass) and a deciduous awn; palea enclosed by the edges of the lemma.

Of the five species growing in California, only three are important as forage. Indian ricegrass is a native perennial, whereas smilo has been naturalized from the Mediterranean region.

\section{Key to Species}

Culms mostly $3 \mathrm{ft}$ ( 1 meter) or more tall; panicle $20-30 \mathrm{~cm}$ long; lemmas smooth 2. O. miliacea Culms rarely more than $2 \mathrm{ft}(60 \mathrm{~cm})$ tall; panicle less than $15 \mathrm{~cm}$ long; lemma pubescent

Panicle narrow; spikelets narrow; lemma elliptic, appressed pubescent, with a long flexuous awn

3. O. kingii

Panicle nearly as broad as long; lemma turgid, densely long-pilose with white hairs

1. O. hymenoides

1. INDIAN RICEGRASS (Oryzopsis hymenoides) is densely tufted, $1-2 \mathrm{ft}(30$ $60 \mathrm{~cm})$ tall; blades slender, involute, nearly as long as the culms; panicle very open, 3-6 in (7-15 cm) long, about as wide, the slender branches in pairs, divaricately branching; pedicels capillary, flexuous; glumes 6-7 mm long, the tips widely gaping; lemma fusiform, turgid, black, densely clothed with long white hairs; awn about $4 \mathrm{~mm}$ long. (Fig. 93.)

Distribution and habitat: Indian ricegrass, one of the most important forage species on ranges east of the Sierra Nevada, occurs from Siskiyou County south to San Bernardino County, and also extends into the southern Coast Range below Los Angeles. (Fig. 94.) It is unusually drought-enduring and occupies dry, sandy soils of semidesert ranges. It 


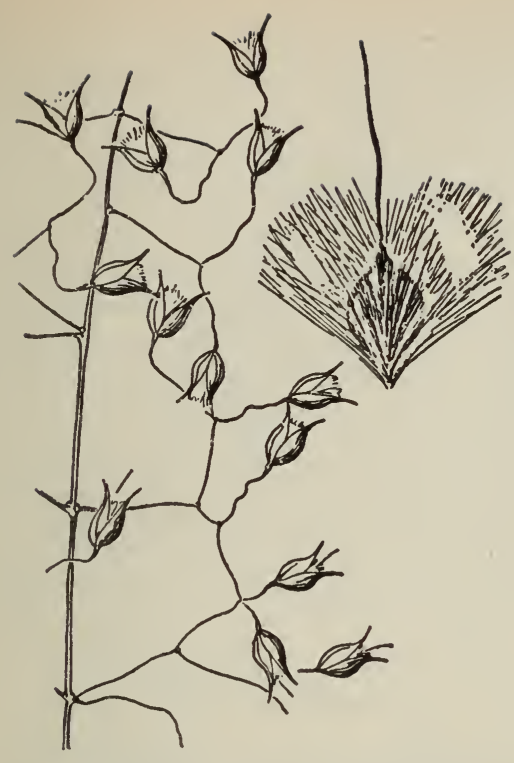

Fig. 93. Indian ricegrass (Oryzopsis hymenoides).

occurs more scatteringly on grass or brush areas of the foothills, and on exposed slopes at higher elevations.

Forage value and reproduction: Indian ricegrass produces abundant basal leaf-

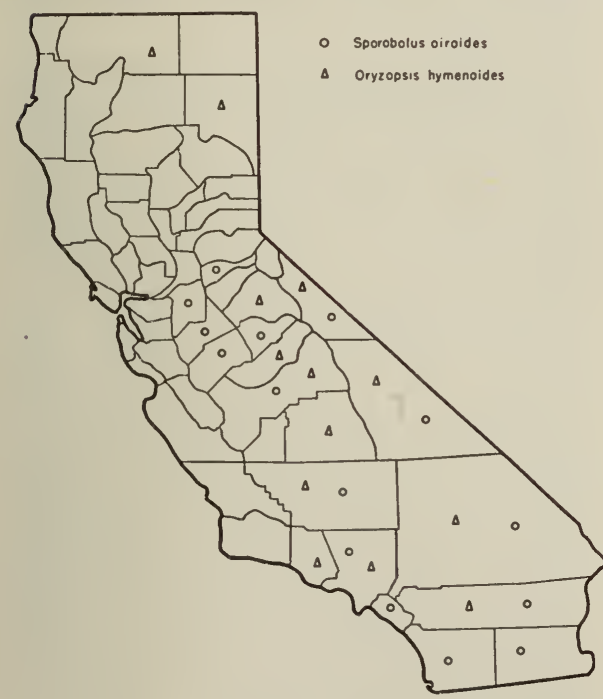

Fig. 94. Distribution of alkali sacaton (Sporobolus airoides) and Indian ricegrass (Oryzopsis hymenoides). age which cures well on the ground and is greatly relished by livestock in winter. The large crop of plump seeds adds to its nutritive value. Unfortunately, heavy grazing in early spring has depleted most stands, and a system of deferred grazing will be required to protect the young growth and restore the formerly productive capacity of Indian ricegrass ranges.

2. SMILO (Oryzopsis miliacea) forms hard clumps; culms robust, sometimes branching, 2-4 ft $(60-150 \mathrm{~cm})$ tall, very leafy, the flat blades 5-10 mm wide; panicle 8-12 in (20-30 cm) long, narrow but loose, the numerous slender branches in distant whorls, ascending, spikeletbearing towards the ends; spikelets about $3 \mathrm{~mm}$ long, acuminate; lemma narrowly obovate, pale, glabrous; awn about $4 \mathrm{~mm}$ long. Introduced from the Mediterranean region.

Smilo occurs along the California coast from San Diego to Mendocino counties. Because of its adaptation to dry soils, it is sometimes seeded for forage on dryland farms in the Central Valley, but a satisfactory stand is often difficult to obtain. It is also used in reseeding chaparral burns. The young growth is fairly palatable to livestock, but if allowed to go ungrazed the herbage soon becomes too rank and coarse for pasturage. If stands are not pastured too heavily late in the season, good reproduction of seed may be expected.

3. KING RICEGRASS (Oryzopsis kingii) is a slender perennial $7-14$ in $(20-40$ $\mathrm{cm}$ ) tall, with a dense tuft of filiform leaves at the base, and a small panicle of shining spikelets with conspicuous curved awns.

King ricegrass occupies dry open ground in the mountains of Mono and Inyo counties westward to Mariposa and Fresno counties up to $11,000 \mathrm{ft}$. Although growing sparsely, forage production in some localities is sufficient to be of some consideration in range management. 


\section{THREEAWNS (ARISTIDA)}

Threeawns are annuals or perennials, with slender, often wiry culms, tufted or branching from the base; spikelets narrow, the glumes acuminate or awntipped; floret with a needle-like callus at base; lemma indurate, convolute, bearing a prominent 3-cleft awn, no line of demarcation between lemma and awn.

There are 13 threeawns in California, but only two species, one annual and the other perennial, occur extensively on range lands. (Fig. 95.)

Although found on a variety of sites, threeawns usually occupy dry, rocky soils of the valley, foothill and desert ranges, especially in the central or southern part of the state. They are earlier in the succession of grasslands than most forage species and frequently become abundant on depleted ranges. Under proper management they usually give way to the more desirable needlegrasses with which they are commonly associated (10).

Mest threeawns are grazed with fair relish when young, and where more palatable plants are not available they furnish

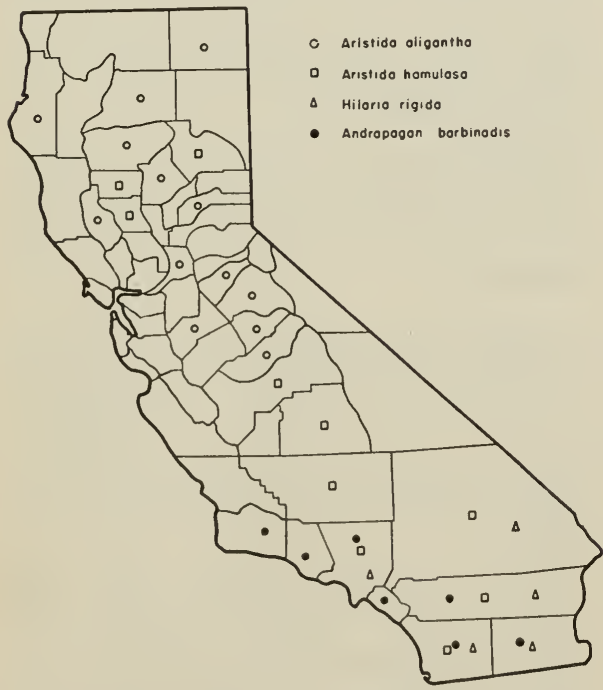

Fig. 95. Distribution of prairie threeawn (Aristida oligantha), Arizona threeawn (A. hamulosa), big galletagrass (Hilaria rigida), and cane beardgrass (Andropogon barbinodis). limited forage on early ranges. The hard, sharp florets with the three-pronged awns become troublesome to livestock as soon as the seed heads dry. After the seeds of perennial threeawns are cast the dry foliage is cropped limitedly in late winter and early spring; but with the coming of autumn rains the mixture of young green shoots induces livestock to graze this feed rather closely. Chemical analyses indicate the nutritive value of threeawns to be fair at most growth stages, but the fiber content is high (39). Grazing animals aid in distributing the heavy seed crops by transporting them through attachment of awns to the wool or skin.

\section{Key to Species}

Plants annual; panicle branches ascending

1. A. oligantha

Plants perennial; panicle branches stiffly spreading

2. A. hamulosa

1. PRAIRIE THREEAWN (Aristida oligantha) is a wiry branching annual $1-2 \mathrm{ft}$ $(30-60 \mathrm{~cm})$ tall; panicles loose, 4-8 in $(10-20 \mathrm{~cm})$ long, the branches ascending; spikelets narrow, the glumes $1-1 \frac{1}{2}$ in $(2-3 \mathrm{~cm})$ long; lemma about $2 \mathrm{~cm}$ long, the spreading awns $4-7 \mathrm{~cm}$ long. (Fig. 96.)

Distribution and habitat: Prairie threeawn is most abundant in the Sacramento and lower San Joaquin valleys. Stands are usually scattered but occasionally become locally abundant on dry hillsides. They also occur on moister sites and are common on sheep ranges.

Forage value and reproduction: Although fairly palatable in the early growth stage, prairie threeawn does not produce much forage until livestock have left for the summer ranges. By the time the animals return in the fall the mature herbage, with its troublesome seed heads, is nearly worthless for grazing. Since the seeds of this grass are well distributed by the grazing livestock, it commonly invades heavily used ranges.

2. ARIZONA THREEAWN (Aristida hamulosa) is a densely tufted perennial with 


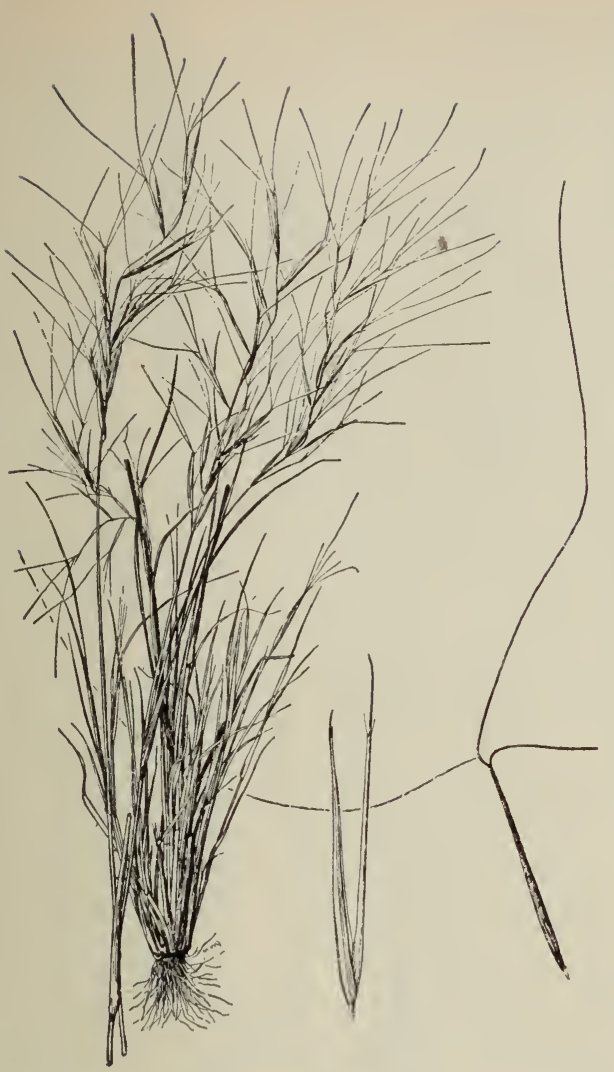

Fig. 96. Prairie threeawn (Aristida oligantha).

rigid ascending or spreading culms $1-2$ $\mathrm{ft}(30-60 \mathrm{~cm})$ long, and long blades; panicle $1 / 3-1 / 2$ the entire length of the plant, the branches stiffly spreading; spikelets appressed to the branches, glumes 1-1.2 cm long, the lemma nearly equal; awns not widely spreading, mostly about $2 \mathrm{~cm}$ long, the lateral a little shorter than the central.

Distribution and habitat: Formerly included in spreading threeawn (Aristida divaricata), Arizona threeawn is a deeprooted perennial which occurs on flats and gravelly hills up to $4000 \mathrm{ft}$. It is found commonly in the lower Sacramento and upper San Joaquin valleys and along the coast of southern California below Los Angeles. It does well on south and west exposures where, on the foothill ranges, it is associated with needlegrasses and squirreltails. The coarse basal leafage is not highly relished by livestock except in early spring and late autumn after the seed has dropped and other forage is scarce. Stands are most abundant on heavily grazed ranges.

\section{DROOPING WOODREED (CINNA LATIFOLIA)}

Drooping woodreed is a tall slender perennial with flat blades $10-15 \mathrm{~mm}$ wide; panicle very loose, drooping, the branches spikelet-bearing towards the ends; spikelets falling entire, glumes and lemma equal, the floret on a minute stalk, lemma with a minute awn from below the tip. (Fig. 97.)

Distribution and habitat: Drooping woodreed is the only species of this genus found in California. It occurs at middle

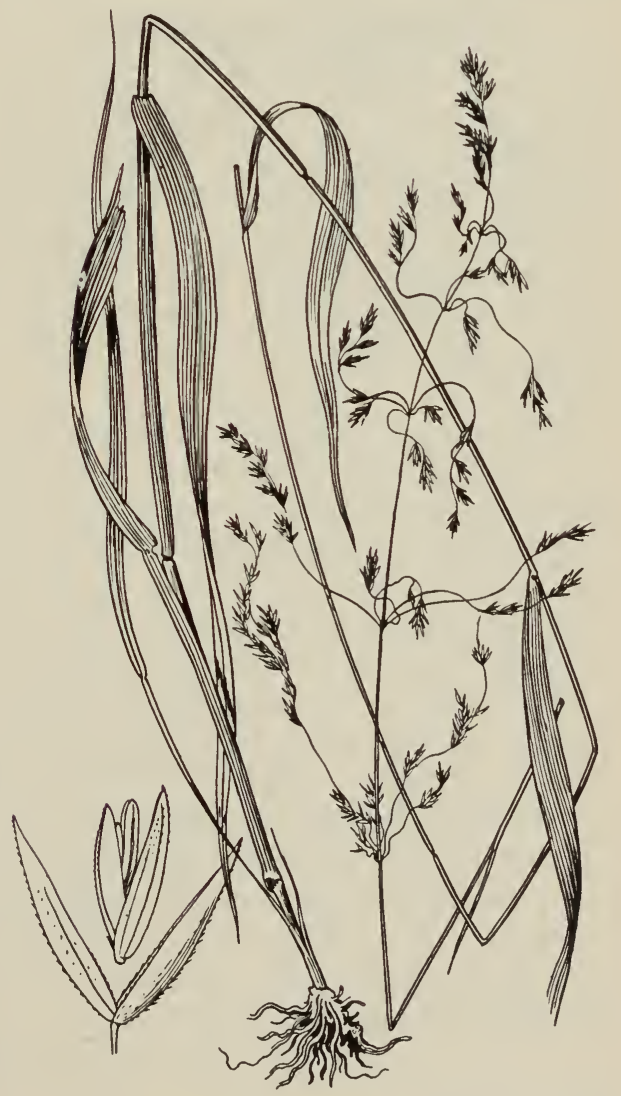

Fig. 97. Drooping woodreed (Cinna latifolia). 
altitudes in the Sierra Nevada from Butte County south to Tulare County, and in the mountains of the northeastern part of the state, principally in Trinity, Shasta, and Siskiyou counties. (Fig. 85.) Its favorite habitat is moist or wet, heavy soils in the shade of timber stands.

Forage value and reproduction: Although highly palatable, drooping woodreed is only of secondary forage value because of its limited distribution. On the summer ranges the broad, rather sparse leafage remains green and tender throughout the grazing season, and is relished by all foraging animals. Because of the damp situations in which it usually grows it is not grazed by sheep early in the season. A good seed crop of good viability is matured in August and September.

\section{NITGRASS (GASTRIDIUM VENTRICOSUM)}

Nitgrass is a weedy annual 8-15 in $(20-40 \mathrm{~cm})$ tall, with scant foliage and dense cylindrical pale shining panicles $2-31 / 2$ in $(5-9 \mathrm{~cm})$ long; spikelets about $5 \mathrm{~mm}$ long, the glumes swollen at base, much longer than the minute, hairy, awned floret. Introduced from Europe. (Fig. 98.)

Distribution and habitat: Collections in the University Herbarium indicate that this annual grass was common in the Bay Area as early as 1900. More recently it has become a pest in the coastal counties, and in the interior counties of northern California up to $4000 \mathrm{ft}$. Nitgrass is often abundant on overgrazed foothill ranges and on recently burned chaparral lands. (Fig. 85.)

Forage value and reproduction: Nitgrass at any growth stage is grazed little or not at all by stock. This fact, together with that of the large viable seed crop produced in late spring, contributes to its rapid spread in the state.

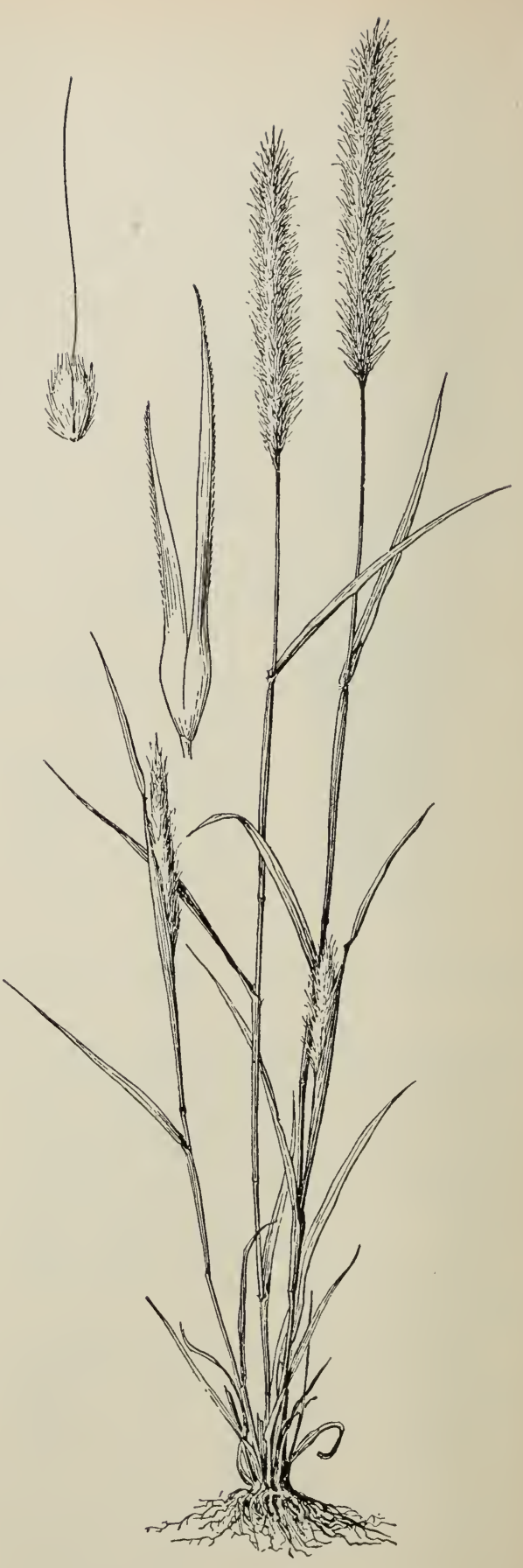

Fig. 98. Nitgrass (Gastridium ventricosum). 


\section{CURLY MESQUITE TRIBE (ZOYSIEAE)}

Spikelets in groups (short spikes) of 3 , sessile along a main axis, falling entire; central spikelet fertile, l-flowered; lateral spikelets staminate, 2-flowered; glumes somewhat asymmetric, lobed and awned at the summit.

\section{BIG GALLETAGRASS (HILARIA RIGIDA)}

Big galletagrass is a robust perennial, forming tough clumps; culms solid,

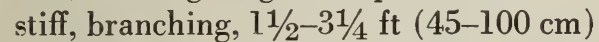
tall. The culms and foliage are densely felty-pubescent; spikelets sessile, in groups of 3 , the groups falling from the axis entire, the central spikelet fertile, the lateral spikelets staminate, the group about $8 \mathrm{~mm}$ long, densely bearded at base; glumes and lemmas lobed or lacerate at the summit, ciliate and with short slender awns. (Fig. 99.)

Distribution and habitat: Big galleta inhabits the dry plains and deserts of southern California. (Fig. 95.) It occupies sand dunes and other barren areas up to $5000 \mathrm{ft}$.

Forage value and reproduction: Although dry and stemmy, big galleta is highly palatable, especially to cattle and horses. It is unusually drought-enduring and "greens up" quickly following good rains. Jepson refers to it as the most valuable forage grass on the desert (30). While reproduction is obtained largely by rhizomes or decumbent culms, a fairly large seed crop matures in June.

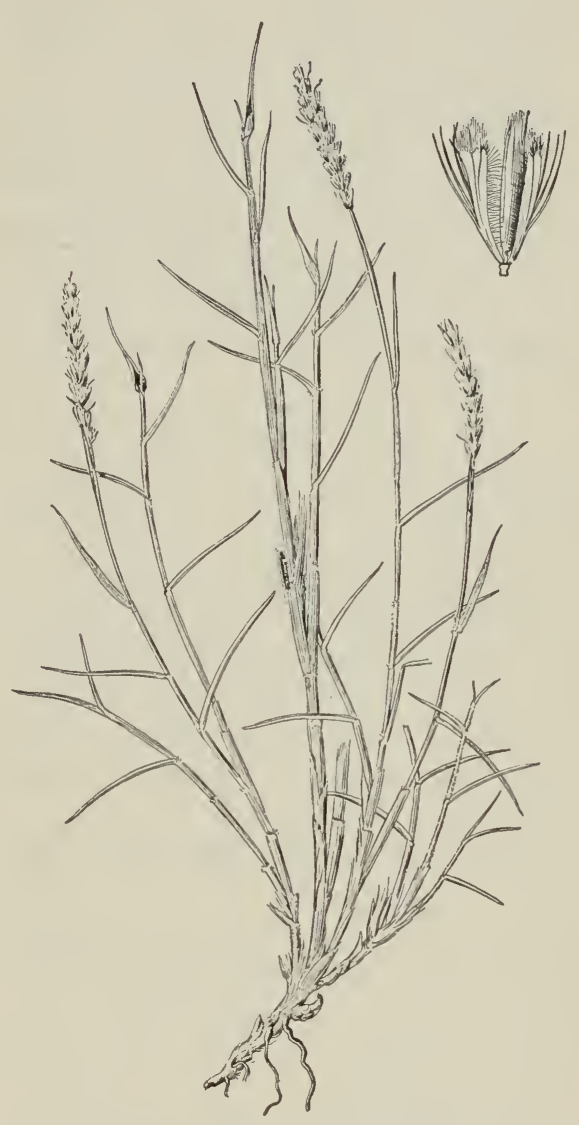

Fig. 99. Big galletagrass (Hilaria rigida).

\section{GRAMA TRIBE (CHLORIDEAE)}

Spikelets 1-several flowered, sessile on one side of a slender continuous rachis, forming l-sided spikes, these digitate or racemose on a common axis.

\section{KEY TO GENERA}

Spikelets I-flowered without additional modified sterile florets

Spikes slender, digitate; glumes persistent

37. Cynodon (p. 107)

Spikes rather thick, racemose on a slender axis; spikelets falling entire 36. Beckmannia (p. 107)

Spikelets with 1 perfect floret and 1 or 2 additional modified sterile florets above

Spikes digitate, feathery

38. Chloris (p. 108)

Spikes racemose, not feathery

35. Bouteloua (p. 106) 


\section{GRAMAGRASSES (BOUTELOUA)}

Gramagrasses have few to several spikes, racemose on a common axis; spikelets with 1 perfect floret and 1 or 2 rudimentary florets borne on a short rachilla above, the spikelets crowded; lemmas and rudiments with short awns.

The gramagrasses are poorly represented on California range lands (fig. 100 ), only two species being important enough to mention. Six weeks grama, an annual, and blue grama, a long-lived perennial, furnishes a limited amount of forage on ranges in the southern part of the state.

\section{Key to Species}

Plants perennial

1. B. gracilis

Plants annual

2. B. barbata

1. BLUE GRAMA (Bouteloua gracilis) is a densely tufted perennial with a mass of fine foliage at base; culms erect, 8-20 in $(20-50 \mathrm{~cm})$ tall; spikes usually 2 (sometimes 1 or 3 ), 2.5-5 cm long, curvedspreading at maturity; spikelets about 5 mm long.

Blue grama is a drought-enduring per-

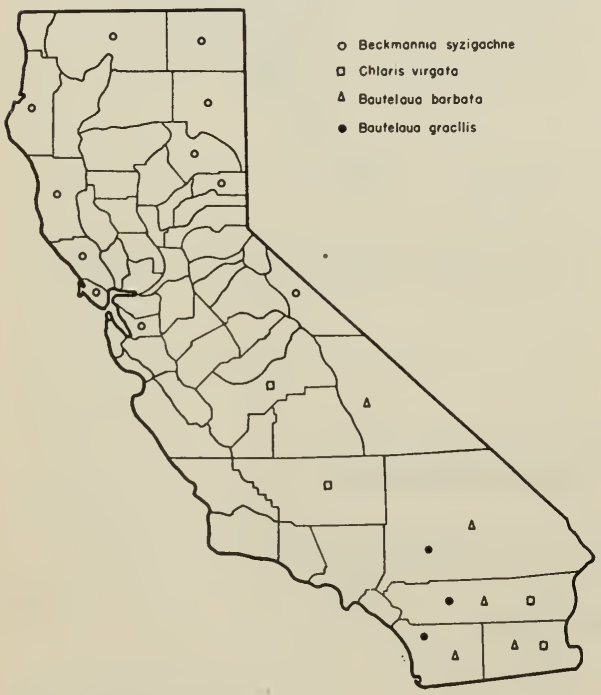

Fig. 100. Distribution of sloughgrass (Beckmannia syzigachne), feather fingergrass (Chloris virgata), six-weeks grama (Bouteloua barbata), and blue grama (B. gracilis).

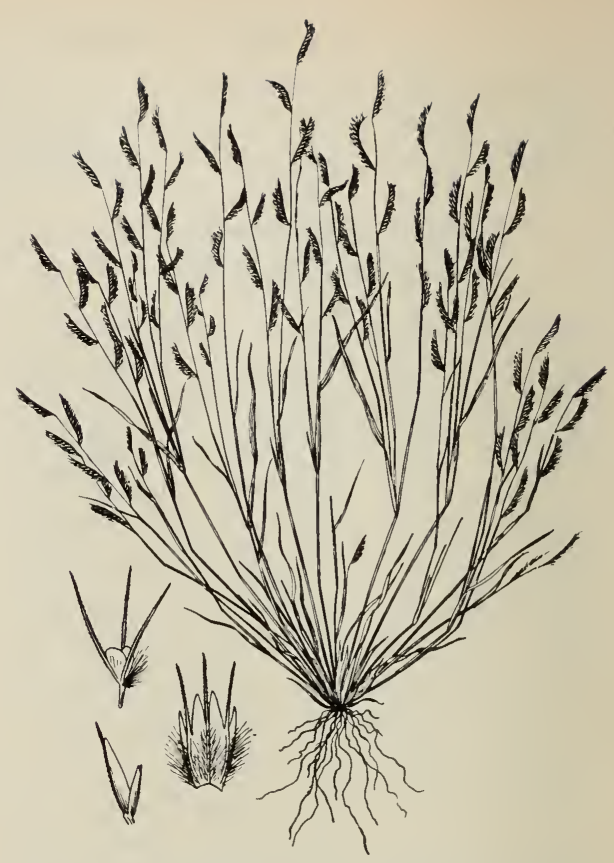

Fig. 101. Six weeks grama (Bouteloua barbata).

ennial which, together with buffalo grass, makes up the bulk of the forage on the short-grass ranges east of the Rocky Mountains. In California it grows abundantly only on open, dry slopes in the San Bernardino Mountains up to $7000 \mathrm{ft}$. It is relished by livestock during all seasons of the year and would be an important forage plant if it were more widely distributed. A good seed crop is produced in August and September.

2. SIX WEEKS GRAMA (Bouteloua barbata) is a low-tufted branching and spreading annual, the slender culms 6-15 in $(15-30 \mathrm{~cm})$ long; foliage scant; spikes 4 to $7,1-2 \mathrm{~cm}$ long; spikelets $2.5-4 \mathrm{~mm}$ long, about as wide. (Fig. 101.)

Distribution and habitat: Six weeks grama is most abundant in the arid portions of San Bernardino, Imperial, and Riverside counties. Along the Colorado River and on flats in the Mojave Desert it occurs in association with prickly pear (Opuntia). It grows up to $5000 \mathrm{ft}$ and, as its name implies, completes its growth 


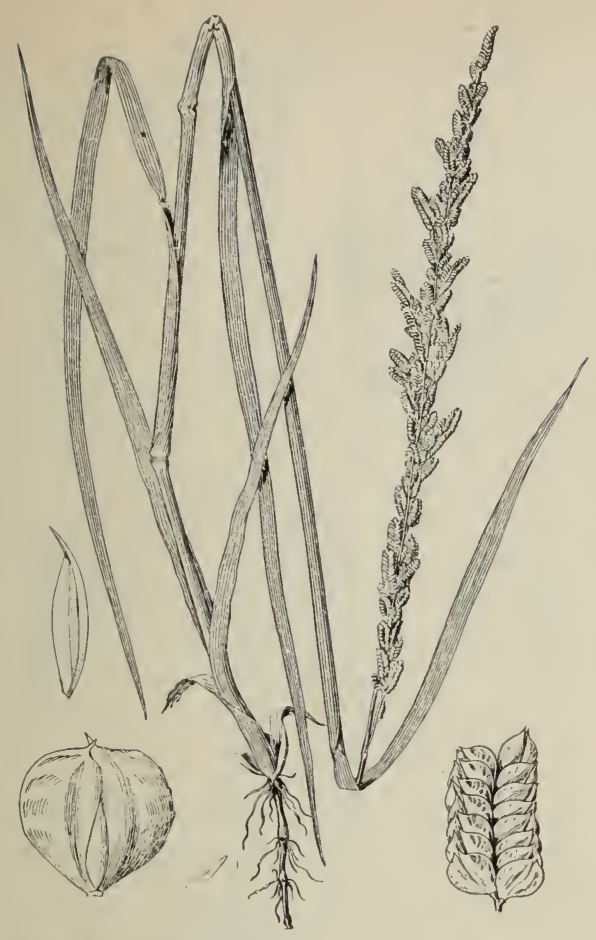

Fig. 102. Sloughgrass (Beckmannia syzigachne).

cycle in a short time following favorable rains.

Forage value: Six weeks grama is palatable to all livestock, but contributes to the forage crop only for short, irregular periods depending on moisture conditions.

\section{SLOUGHGRASS (BECKMANNIA SYZIGACHNE)}

Sloughgrass is a stout lush leafy annual, $1-3 \frac{1}{4} \mathrm{ft}(30-100 \mathrm{~cm})$ tall, with numerous short spikes short-peduncled on an erect axis 4-10 in (10-25 cm) long; spikelets 1-flowered, $3 \mathrm{~mm}$ long, about as wide, falling entire; glumes broad, somewhat inflated and transversely wrinkled; floret narrow, boatshaped, acuminate. (Fig. 102.)

Distribution and habitat: Sloughgrass grows in wet places, along sloughs, and in adobe meadows, from Mono County north in the Sierra Nevada, and in the Coast Range from San Francisco Bay northward. It ranges from sea level to 6500 ft. (Fig. 100.)

Forage value and reproduction: Cattle and horses graze the grass rather closely throughout the season, and it has a higher preference rating than the associated rushes and sedges. Sheep relish the herbage before it becomes coarse, but make little use of it because of its wet habitat. Stands produce a large viable seed crop.

\section{BERMUDAGRASS (CYNOEON DACTYLON)}

Bermudagrass is a perennial, extensively creeping by scaly rhizomes or strong flat stolons; flowering culms flat, wiry, and leafy, $4-15$ in $(10-40 \mathrm{~cm})$ tall; spikelets small, 1-flowered, flat, sessile, in slender digitate spikes, $2.5-5 \mathrm{~cm}$ long; lemma slightly longer than the glumes, the rachilla prolonged behind the palea as a slender bristle. (Fig. 103.)

Distribution and habitat: Bermuda-

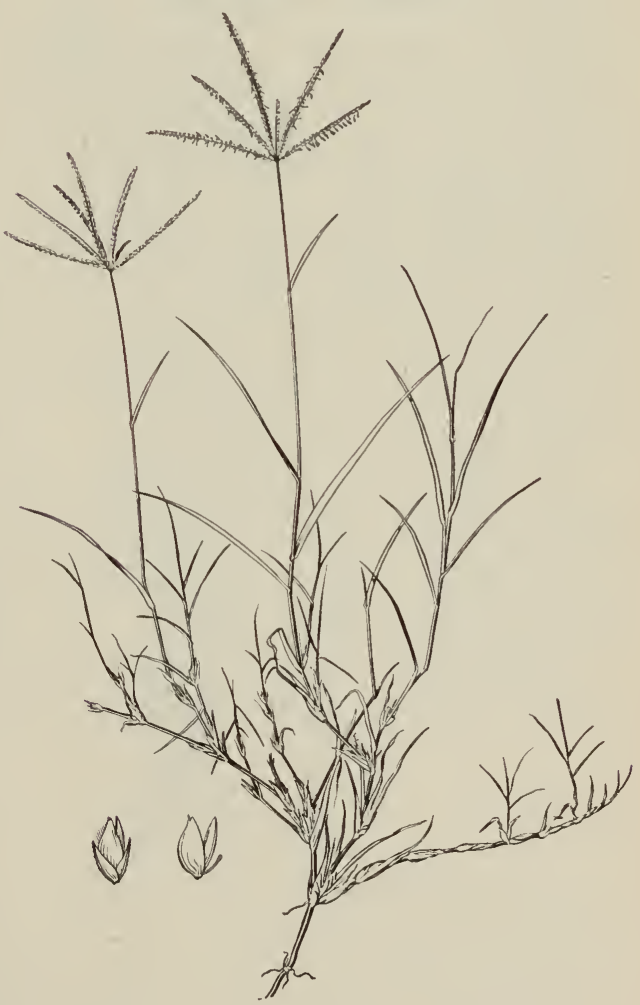

Fig. 103. Bermudagrass (Cynodon dactylon). 
grass is a valuable turf-forming representative of the grama tribe. In the warmer parts of the state it is commonly used as a lawn grass. It is widely distributed in the Sacramento, San Joaquin, and Imperial valleys, where it is frequently a troublesome weed and an undesirable constituent of some irrigated pastures. Bermudagrass grows well on soils ranging from light sands to heavy clays, and is drought-resistant and alkalitolerant.

Forage value and reproduction: Young growth is palatable to livestock, but the mature herbage becomes harsh and fibrous. Unless abundant moisture is available throughout the grazing season, Bermudagrass does not produce much pasturage. Reproduction both by seed and by rhizomes and stolons is good.

\section{FEATHER FINGERGRASS (CHLORIS VIRGATA)}

Feather Fingergrass is a tufted leafy annual, ascending to spreading, 8-24 in $(20-60 \mathrm{~cm})$ long, with flat culms and keeled sheaths, the upper inflated; spikes several, digitate, $1-3$ in $(3-8 \mathrm{~cm})$ long, pale, feathery; spikelets crowded, with 2 florets, the lower perfect, the lemma hump-backed and hairy on the keel, longciliate and with a slender awn at the summit, the upper floret sterile, the lemma truncate, awned. (Fig. 104.)

Distribution and habitat: Feather fingergrass inhabits southern plains and foothills up to $5000 \mathrm{ft}$. (Fig. 100.) It grows in dry soils along the Colorado River and in Riverside County.

Forage value and reproduction: Feather fingergrass is the only native

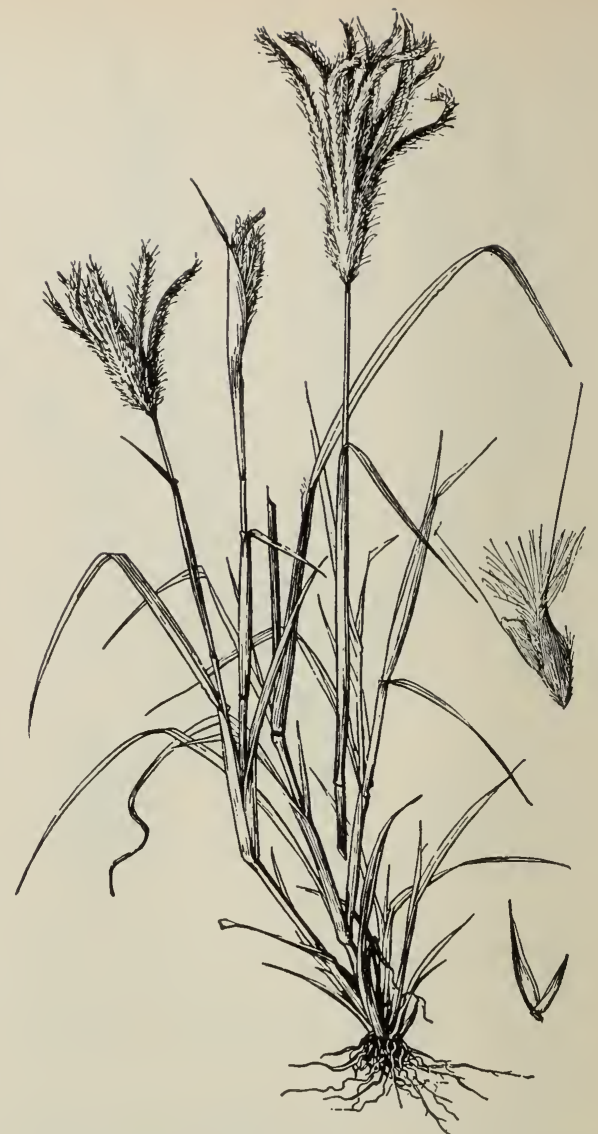

Fig. 104. Feather fingergrass (Chloris virgata).

Chloris species valuable as forage. The introduced Rhodesgrass ( $C$. gayana) is being used some for irrigated pasture on warmer, alkaline sites (31), but does not endure much cold. Feather fingergrass is relished in the early part of the grazing season, but mature plants become stemmy and the feathery seed heads are not sought by livestock. A fairly large seed crop is cast during May and June. 


\section{CANARYGRASS TRIBE (PHALARIDEAE)}

Of the four genera of this tribe known to occur in California, only three have any forage value.

Lower florets awned

\section{KEY TO GENERA}

Lower florets awnless

Lower florets reduced to minute scales; panicle spikelike

Lower florets well developed, sterile; panicle narrow but loose

40. Anthoxanthum (p. 110)

39. Phalaris (p. 109)

41. Ehrharta (p. 110)

\section{CANARYGRASS (PHALARIS)}

Leafy annuals or perennials, with dense panicles; spikelets with 1 terminal perfect floret and 2 (rarely 1 ) scalelike sterile lemmas below, these falling attached to the mature floret; glumes keeled, often winged on the keel, longer than the floret; fertile lemma coriaceous, laterally compressed.

\section{Key to Species}

Plants annual; spikelets in clusters falling entire; glumes of outer spikelets club-shaped

3. P. paradoxa var. praemorsa Plants perennial; glumes persistent on the pedicels, none club-shaped

Panicle ovoid, about $2 \mathrm{~cm}$ thick; spikelets 6-8 mm long

2. P. californica

Panicle cylindric, mostly $6-15 \mathrm{~cm}$ long, 1.5 $\mathrm{cm}$ thick; spikelets 5-6 $\mathrm{mm}$ long

1. P. tuberosa var. stenoptera

1. HARDINGGRASS (Phalaris tuberosa var. stenoptera) is perennial from strong loosely branching rhizomes; culms stout, $21 / 2-41 / 2 \mathrm{ft}(75-150 \mathrm{~cm})$ tall, very leafy, blades $5-10 \mathrm{~mm}$ wide; panicles $5-15 \mathrm{~cm}$ long; glumes 5-6 mm long; fertile lemma 4. $\mathrm{mm}$ long, with but 1 minute sterile lemma. (Fig. 105C.)

Distribution and habitat: Hardinggrass is an introduced perennial that has been found suitable for reseeding California brush ranges and retired grainficlds $(36,51)$. It thrives best on heavy black soils and on deep volcanic loams, but will produce well on lighter soils underlaid by heavier strata $(31,32)$.

Forage value and reproduction: The large dense leafy tufts are relished by all classes of livestock. Hardinggrass is one of the few perennials to make good growth in winter when most other plants are dormant. It produces fair seed crops, but new stands are not readily established except under skillful management.

\section{CALIFORNIA CANARYGRASS (Pha-} laris californica) is a perennial often in

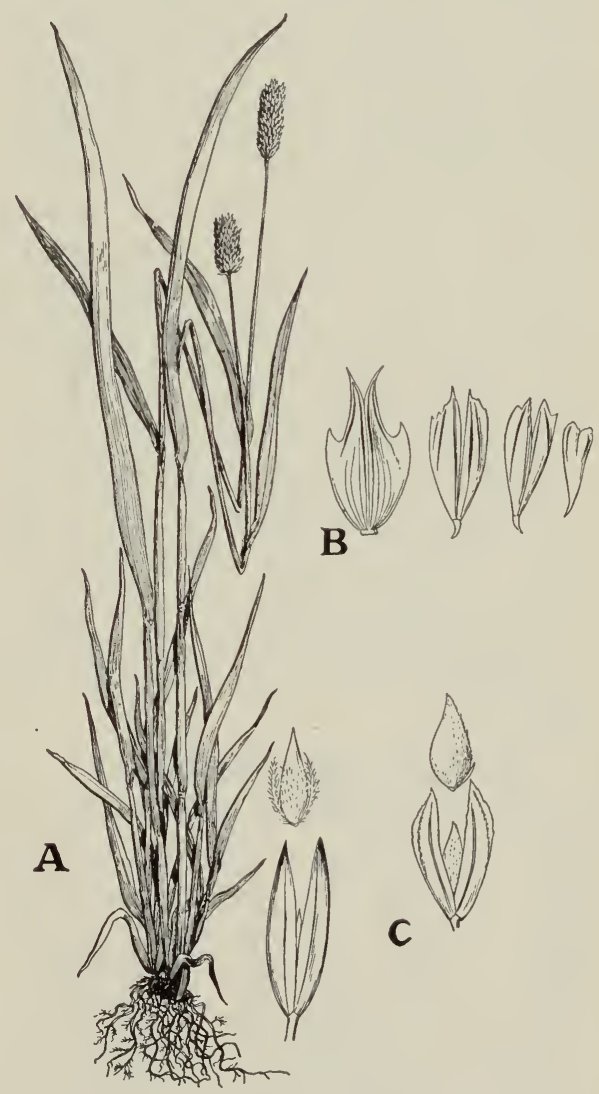

Fig. 105. A, California canarygrass (Phalaris californica); B, club canarygrass (P. paradoxa var. praemorsa), showing fertile and sterile spikelets; C, spikelet and floret of Hardinggrass ( $P$. tuberosa var. stenoptera). 
dense tussocks; culms $2 \frac{1}{2}-41 / 2 \mathrm{ft}$ (75$160 \mathrm{~cm}$ ) tall, very leafy, the blades 8-15 mm wide; panicle ovoid $1-21 / 2$ in $(2-5$ $\mathrm{cm}$ ) long, about $2 \mathrm{~cm}$ thick, often purpletinged; glumes 6-8 $\mathrm{mm}$ long; fertile lemma about $4 \mathrm{~mm}$ long, the narrow sterile lemmas $1 / 2-2 / 3$ as long, ciliate. (Fig. 105A.)

California canarygrass is a native species found in the coastal regions north of San Luis Obispo County at low altitudes. It grows in moist, open ground or swampy places in woods, and provides good forage where abundant.

3. CLUB CANARYGRASS (Phalaris paradoxa var. praemorsa) is a tufted branching annual, spreading at base; culms 824 in $(20-60 \mathrm{~cm})$ tall; panicle $1 \frac{1}{2}-3$ in (4-8 cm) long, about $1 \mathrm{~cm}$ thick; spikelets in groups of 7,1 fertile, surrounded by 6 sterile, the group falling entire; glumes of fertile spikelets with a toothlike wing on the keel, the apex acuminate, the pair resembling sharp horns above the club-shaped glumes. Originally introduced from the Mediterranean region. (Fig. 105B.)

Club canarygrass is common in grain fields from San Diego County north to the Sacramento Valley (45). The foliage, like that of most canarygrasses, is readily eaten by livestock, and the plant adds to the forage value of the aftermath growth of grain crops, especially in rice fields.

\section{SWEET VERNALGRASS (ANTHOXANTHUM ODORATUM)}

Sweet vernalgrass is a tufted fragrant perennial with flat blades and spikelike panicles; spikelets narrow, the glumes unequal, exceeding the florets; sterile florets pilose with golden hairs, awned, the awn of the first straight, of the second longer and bent; fertile floret much smaller, brown, smooth and shining. Naturalized from Europe.

Sweet vernal occupies meadows and waste ground of low elevation in Humboldt and Del Norte counties. Although producing a fair amount of leafage it is of low palatability to stock, and should not be confused with good forage grasses.

\section{VELDTGRASSES (EHRHARTA)}

Veldtgrasses are mostly leafy; spikelets with 2 sterile lemmas about as large as the fertile lemma, or longer, the three falling together. Several species are native to South Africa; a few are found in Australia, mostly introduced. Two have been sparingly introduced in California.

\section{Key to Species}

Culms weak, freely branching; spikelets 3-3.5 $\mathrm{mm}$ long; sterile lemmas glabrous 1 . E. erecta Culms erect, simple; spikelets $7 \mathrm{~mm}$ long; sterile lemmas long-pilose

2. E. calycina

\section{LEAFY VELDTGRASS (Ehrharta erecta)} is a weak-stemmed branching leafy perennial with flat blades and loose panicles 6-15 cm long; spikelets pale, 3-3.5 mm long, blunt; sterile lemmas glabrous, the second cross-wrinkled. Introduced from South Africa.

2. VELDTGRASS (Ehrharta calycina) is an erect perennial $1-2 \frac{1}{2} \mathrm{ft}(30-75 \mathrm{~cm})$ tall, with flat blades and loose narrow panicles; spikelets about $7 \mathrm{~mm}$ long, purplish, spreading or nodding on slender pedicels; sterile lemmas loosely longpilose. Introduced from South Africa in Australia, whence seed was obtained for experiments at Davis, California.

Both species show some promise as drought-resistant bunchgrasses for range lands in California. Preliminary seeding trials of veldtgrass in Orange County have shown some promise of success to date. Livestock seem to relish its herbage. 


\section{MILLET TRIBE (PANICEAE)}

Spikelets with 1 terminal perfect floret and below this a sterile floret and 2 glumes; fertile lemma and palea indurate, the palea enclosed by the margins of the lemma; glumes and sterile lemma usually simulating 3 glumes; spikelets falling entire.

\section{KEY TO GENERA}

Inflorescence nct hidden in the upper sheath

\section{Spikelets awnless}

Spikelets subsessile and crowded on a flat rachis, forming racemes; first glume typically wanting

Spikelets pediceled in panicles, biconvex; first glume developed

42. Paspalum (p. 111)

spikelets with glumes or sterile lemma awned

Inflorescence hidden in the upper sheath; creeping perennial

43. Panicum (p. 112)

44. Echinochloa (p. 112)

45. Pennisetum (p. 113)

\section{PASPALUM}

\section{Key to Species}

Spikelets fringed on the margin with white hairs; plants erect

1. P. dilatatum

Spikelets not fringed; plants creeping

2. P. distichum

\section{DALLISGRASS (Paspalum dilatatum)} is a tufted leafy perennial $2-31 / 2 \mathrm{ft}(60$ $150 \mathrm{~cm}$ ) tall, ascending or erect from a decumbent base; blades elongate, 5-12 $\mathrm{mm}$ wide; spikelets subsessile and crowded in racemes, the few to several rather thick racemes $21 / 2-3$ in $(6-8 \mathrm{~cm})$ long, borne on a slender axis, the spikelets compressed, ovate, pointed, about 3 $\mathrm{mm}$ long, the margin fringed with long white silky hairs. Introduced from South America. (Fig. 106.)

Distribution: Dallisgrass is grown for pasturage in irrigated sections of central and southern California.

Forage value and reproduction: The basal leafage is relished by livestock while young but is less palatable as it matures. Although it starts growth late in the spring and becomes dormant in the fall, during the summer Dallisgrass recovers more rapidly from grazing than any other grass (31). Dallisgrass has a strong root system. Seed production is large and stands are gradually extending their range in irrigated sections.

2. KNOTGRASS (Paspalum distichum) is a widely creeping leafy perennial, often making fairly dense carpet along irrigation ditches; racemes usually 2 , suberect; spikelets about $3 \mathrm{~mm}$ long, acute, nearly glabrous; first glume sometimes developed on a few spikelets.

Knotgrass is a midsummer forage plant of considerable usefulness in the moister areas of the California foothills.

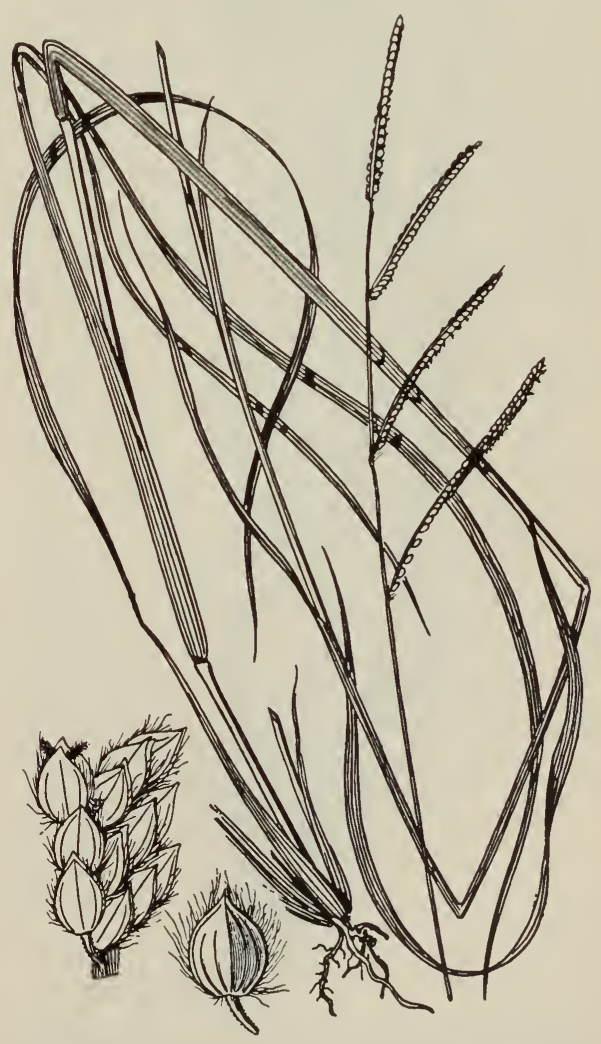

Fig. 106. Dallisgrass (Paspalum dilatatum). 
(Fig. 108.) Palatability of the herbage is high.

\section{PACIFIC PANICUM (PANICUM PACIFICUM)}

Pacific Panicum is a slender tufted pilose perennial, very leafy at base; spring culms $10-20$ in $(25-30 \mathrm{~cm})$ tall, leafy; panicle $2-4$ in $(5-10 \mathrm{~cm})$ long, open,

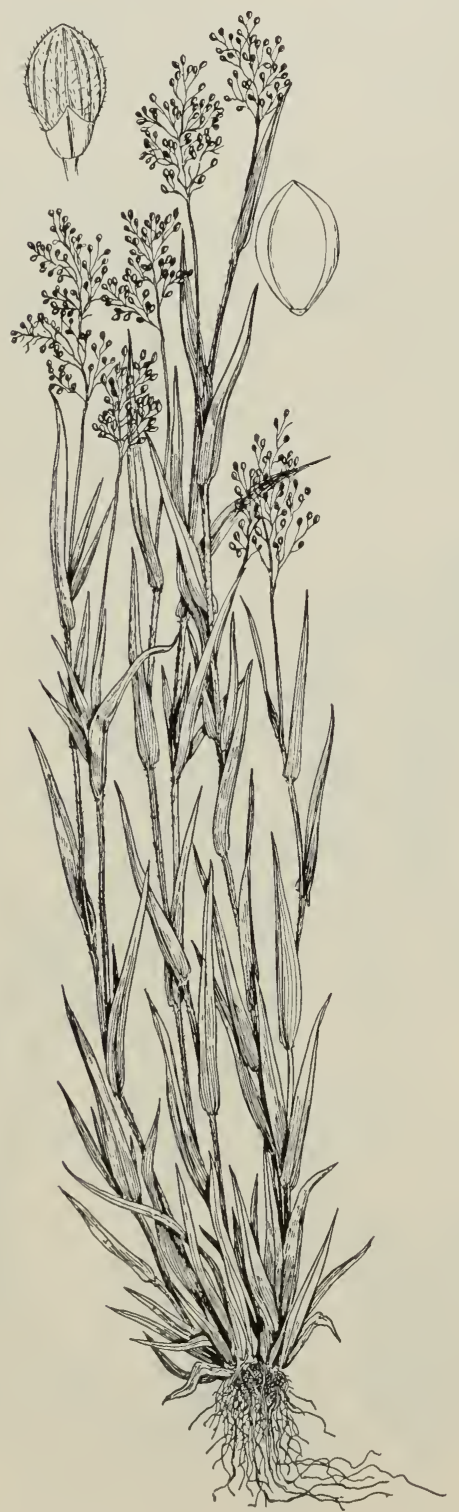

Fig. 107. Pacific panicum (Panicum pacificum). Spring growth stage.

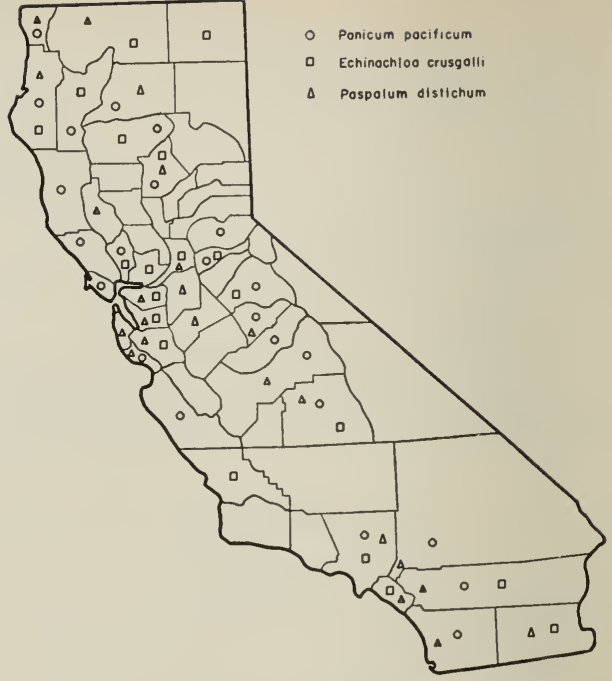

Fig. 108. Distribution of pacific panicum (Panicum pacificum), barnyardgrass (Echinochloa crusgalli), and knotgrass (Paspalum distichum).

nearly as broad; spikelets turgid, about $2 \mathrm{~mm}$ long; culms branching and spreading in July and August, producing short very leafy shoots with reduced panicles. (Fig. 107.)

Distribution and habitat: Pacific panicum grows along the coast and in the Sierra Nevada on sandy soils of granitic origin. (Fig. 108.) It is most common in damp areas and is found in the mountains up to $6000 \mathrm{ft}$. The vernal growth is fairly leafy and upright, whereas the autumnal growth is more prostrate and spreading.

Forage value: Of the 14 species of panicum in California this is the only one that affords much grazing. The plants are pastured rather closely throughout the season but are not abundant enough to furnish more than limited forage.

\section{BARNYARDGRASS (ECHINOCHLOA CRUSGALLI)}

Barnyardgrass is a coarse glabrous leafy annual, branching at base, the culms $2-3 \frac{1}{2} \mathrm{ft}(60-120 \mathrm{~cm})$ tall, at first rather succulent, drying compressed, ridged or angled; blades elongate, 5-15 


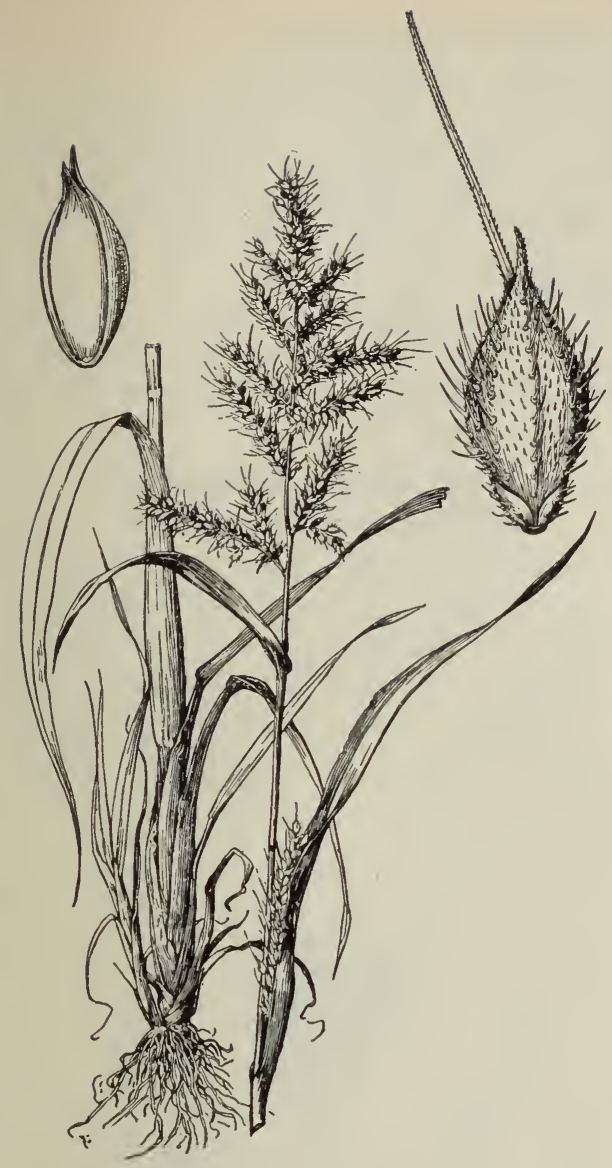

Fig. 109. Barnyardgrass (Echinochloa crusgalli).

$\mathrm{mm}$ wide; panicle $4-8$ in $(10-20 \mathrm{~cm})$ long, the thick spikelike branches ascending or spreading, often purplish; spikelets subsessile, irregularly crowded; the glumes and sterile lemma bristly-hispid at maturity, the sterile lemma with an awn 2-15 $\mathrm{mm}$ long, variable in a single branch; fertile lemma indurate, acuminate-pointed, the tip of the palea not enclosed. (Fig. 109.)
Distribution and habitat: Barnyardgrass, also called watergrass, is an introduced annual that is found in all agricultural sections of California (Fig. 108.) It occurs in moist pastures, in irrigated fields and orchards, and along streams and ditches (45).

Forage value and reproduction: The rapidly maturing foliage is not particularly palatable to stock. When growing on cropland the plants usually remain ungrazed until the herbage has become coarse and dry. The cultural practices used in the production of rice, cotton and beans have been favorable to the spread of this grass. Seed production is prodigious and barnyardgrass rapidly spreads to cultivated lands and livestock lots kept bare by trampling.

\section{KIKUYUGRASS (PENNISETUM CLANDESTINUM)}

Kikuyugrass is an extensively creeping leafy perennial with sparsely pilose foliage; flowering culms compressed, the few-flowered inflorescence enclosed in the upper sheath, only the inconspicuous long stigmas and stamens protruding. First introduced into California from Africa some 20 years ago.

Once established, Kikuyugrass is tenacious and little injured by grazing. It has been planted to prevent erosion in San Diego County (45). It does not endure severe winter weather, hence is most suitable for revegetation in the milder climatic units of California, as along the coast. In a few localities it is regarded as a pest in lawns and orchards. Kikuyugrass is an excellent forage grass in highland valleys in Peru, where it is grown by English sheepmen. 


\section{SORGHUM TRIBE (ANDROPOGONEAE)}

Spikelets in pairs, one sessile and perfect, the other pediceled, staminate or neuter, the pairs borne on a continuous or a disarticulating rachis, the rachis solitary, in pairs, or several to many on a common axis, or on the branches of a panicle; fertile spikelets consisting of one perfect terminal floret and, below this, a staminate or neuter floret, the lemmas thin or hyaline; glumes firm or indurate, awnless.

\section{KEY TO GENERA}

Racemes of several to many joints, solitary, digitate, or aggregate in a panicle

46. Andropogon (p. 114)

Racemes reduced to 1 or few joints, these peduncled in a compound panicle 47 . Sorghum (p. 114)

\section{CANE BEARDGRASS (ANDROPOGON BARBINODIS)}

Cane beardgrass is a tufted perennial, knotty at base; culms 2-31/2 ft (60-130 $\mathrm{cm}$ ) tall, dry and solid, the nodes whitebearded; spikelets in pairs, at each node of a jointed rachis, one sessile and perfect, the other pediceled, sterile and reduced to small glumes; rachis joints and pedicels white silky-haired; racemes 2-6 cm long, crowded on a simple axis, forming a feathery panicle $3-4$ in $(7-10 \mathrm{~cm})$ long, the axis readily breaking; perfect spikelets 5-6 mm long, with a delicate geniculate awn about $2 \mathrm{~cm}$ long. (Fig. 110.)

Distribution and habitat: Cane beardgrass, or plumed beardgrass, grows in valleys and on low hills of southern California from Santa Barbara to San Diego and eastward. (Fig. 95.) Although found on a variety of sites, it commonly grows on well-drained soils. This grass is unusually drought-resistant and is invaluable on ranges where the annual rainfall is as low as 5-6 in (10). It is frequently found along dry washes or gullies but generally only in scattered stands.

Forage value and reproduction: Like most beardgrasses or bluestems-the large group of important forage grasses of the Great Plains to which cane beardgrass belongs-this species is relished by all stock until seed maturity. It is more palatable to cattle and horses than to sheep. Flower stalks appear in February and a fair seed crop matures in April and May.

\section{JOHNSONGRASS (SORGHUM HALEPENSE)}

Johnsongrass is a robust perennial with strong creeping rhizomes; culms 2$4 \mathrm{ft}(60-150 \mathrm{~cm})$ tall, leafy, the blades elongate, $1-2 \mathrm{~cm}$ wide; panicle $6-10$ in (15-35 cm) long, loose or rather dense; spikelets in pairs, one sessile and perfect,

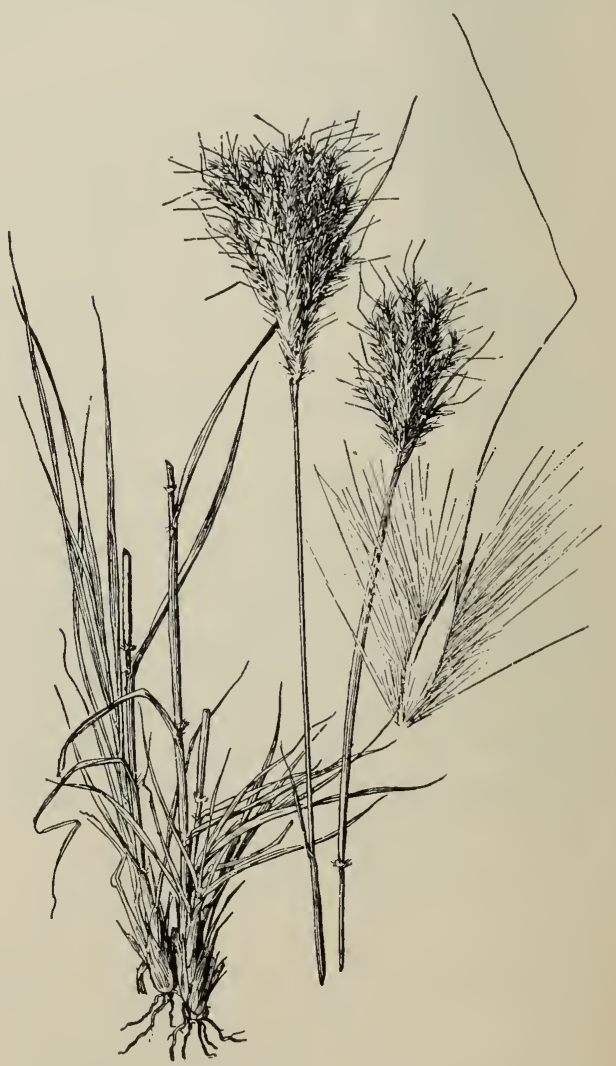

Fig. 110. Cane beardgrass (Andropogon barbinodis). 


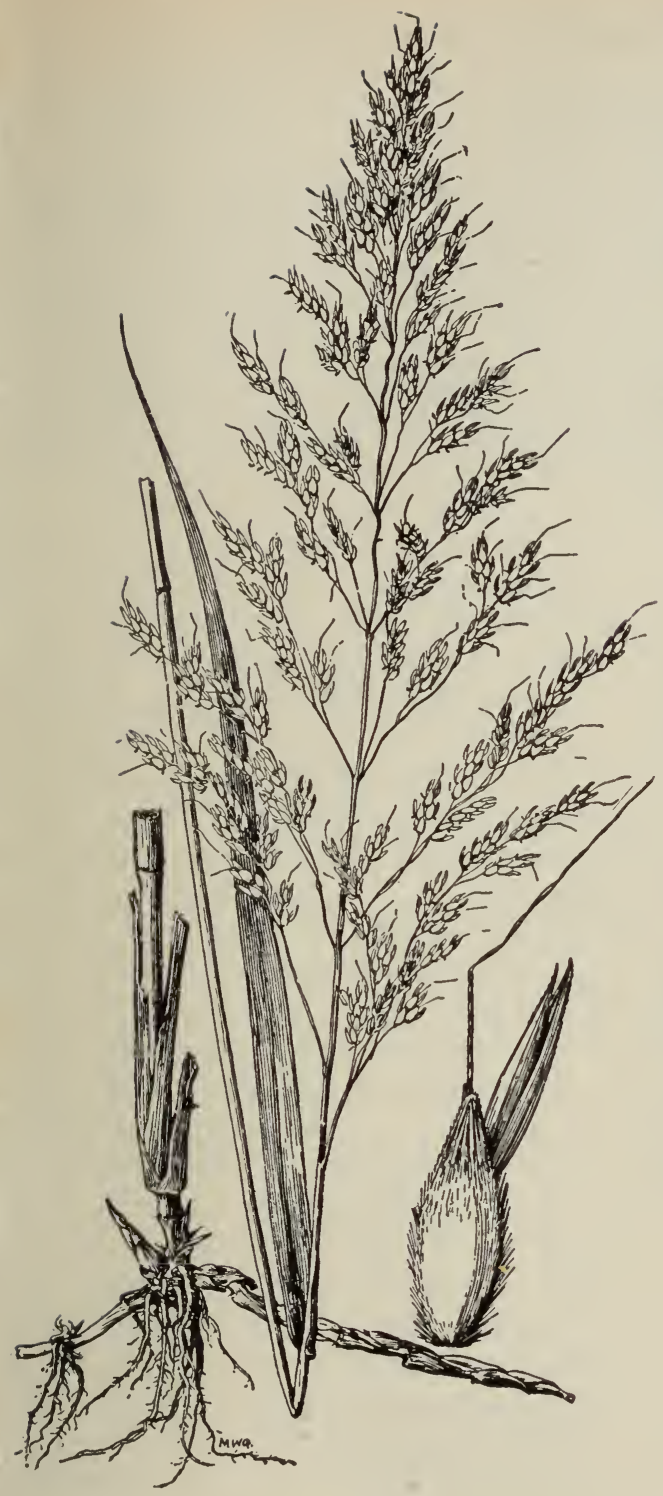

Fig. 111. Johnsongrass (Sorghum halepense). the other pediceled, staminate or empty, 1 to 5 pairs in short racemes, these borne on the branches of a compound panicle; perfect spikelets about $5 \mathrm{~mm}$ long, plump, with a delicate bent awn about 1 cm long, readily falling; rachis joints and pedicels short-hairy. (Fig. 111.)

Distribution and habitat: Johnsongrass is an aggressive perennial with strong rhizomes that has become a serious pest in many agricultural areas of California. It grows over a wide range of soil and moisture conditions, but is most abundant on cultivated areas.

Forage value and reproduction: The leafage is relished by all classes of livestock. As a forage plant Johnsongrass suffers by becoming sodbound when the soil is not occasionally stirred. Heavy grazing by hogs who relish the rhizomes is sometimes used as a control measure on badly infested fields. Under certain conditions Johnsongrass causes hydrocyanic poisoning. Young plants are more toxic than mature ones, especially when growth is interrupted, as by frost or drought (45). Johnsongrass makes palatable hay, and when fed as such causes no poisonous effects. Reproduction is vigorous by means of rhizomes, yet a large amount of good seed is produced. 


\section{A CHECKLIST OF CALIFORNIA GRASSES}

The following is an inclusive list of grasses growing naturally in California. It is arranged by tribes and genera. For an alphabetical list of the range grasses discussed in the preceding sections, consult the Index, pp. 128-130.

Names used in Hitchcock's Manual of the Grasses of the United States (20), 1935 and 1950, or in Jepson's Manual of the Flowering Plants of California (30), not here listed as valid are given in parentheses after the name to which they are referred, in the following way. Synonyms, i.e., names based on the same species, are given with authorities; for example, Bromus porteri Nash appears in parentheses after $B$. anomalus Rupr. Names erroneously applied are given without authorities as "misapplied"; thus, the California species of Crypsis is found to be the Egyptian species, C. niliaca Fig. \& De Not., not the European C. aculeata (L.) Ait., and therefore the latter is given in parentheses as "misapplied."

\section{FESTUCEAE}

\section{Bromus L.}

B. catharticus Vahl (B. unioloides (Willd.) H. B. K.)

B. breviaristatus Buckl. (B. subvelu. tinus Shear)

B. carinatus Hook. \& Arn.

B. arizonicus (Shear) Stebbins

B. marginatus Nees

B. maritimus (Piper) Hitchc.

$B$. polyanthus Scribn.

$B$. inermis Leyss.

$B$. erectus Huds.

B. suksdorfii Vasey

B. orcuttianus Vasey

var. hallii Hitchc.

B. grandis (Shear) Hitchc.

$B$. laevipes Shear

B. vulgaris (Hook.) Shear

B. ciliatus $\mathrm{L}$.

B. anomalus Rupr. (B. porteri Nash)

B. brizaeformis Fisch. \& Mey.

$B$. secalinus $\mathrm{L}$.

B. commutatus Schrad.

var. apricorum Simonkai

$B$. mollis L. (B. hordeaceus misapplied)

B. molliformis Lloyd

B. racemosus $\mathrm{L}$.

B. scoparius L.

B. japonicus Thunb.

$B$. arvensis $\mathrm{L}$.

B. arenarius Labill.

B. rigidus Roth

var. gussonei (Parl.) Coss. \& Dur.

B. sterilis L.
B. rubens L.

$B$. madritensis $\mathrm{L}$.

B. tectorum $\mathrm{L}$. var. glabratus Spenner

B. trinii Desv. var. excelsus Shear

Brachypodium Beauv.

B. distachyon (L.) Beauv.

\section{Festuca L.}

$F$. octoflora Walt. var. hirtella Piper

F. megalura Nutt.

F. dertonensis Aschers. \& Graeb. (F. bromoides misapplied)

F. myuros L.

$F$. pacifica Piper var. simulans Hoover

$F$. confusa Piper

F. grayi (Abrams) Piper

$F$. arida Elmer

$F$. reflexa Buckl.

$F$. microstachys Nutt.

F. eastwoodae Piper

$F$. tracyi Hitchc.

F. subuliflora Scribn.

F. subulata Trin.

F. elmeri Scribn. \& Merr. var. conferta (Hack.) Hitchc.

$F$. elatior L.

$F$. arundinacea Schreb. (F. elatior var. arundinacea (Schreb.) Wimm.)

$F$. californica Vasey

$F$. viridula Vasey ( $F$. howellii Hack.)

F. rubra L.

F. occidentalis Hook. 
F. ovina L. var. brachyphylla (Schult.) Piper (F. brachyphylla Schult., F. supina misapplied)

F. idahoensis Elmer

\section{Scleropoa Griseb.}

S. rigida (L.) Griseb.

\section{Puccinellia Parl.}

$P$. parishii Hitchc.

P. simplex Scribn.

P. lemmoni (Vasey) Scribn.

P. distans (L.) Parl.

$P$. airoides (Nutt.) Wats. \& Coult. ( $P$. nuttalliana (Schult.) Hitchc.)

$P$. grandis Swallen (P. nutkaensis, $P$. paupercula var. alaskana, and $P$. angustata misapplied)

Glyceria R. Br. (Panicularia Heist.)

G. borealis (Nash) Batchelder

G. leptostachya Buckl.

G. occidentalis (Piper) J. E. Nels. ( $G$. fluitans misapplied)

$G$. declinata Breb. (G. cookei Swallen)

G. pauciflora Presl.

$G$. erecta (Hitchc.) Hitchc. (G. californica Beetle)

G. striata (Lam.) Hitchc. (G. nervata (Willd.) Trin.)

G. elata (Nash) Hitchc.

\section{Pleuropogon R. Br.}

$P$. californicus (Nees) Benth.

$P$. refractus (A. Gray) Benth.

$P$. hooverianus (Benson) J. T. Howell

$P$. davyi Benson

\section{Hesperochloa Rydb.}

H. kingii (S. Wats.) Rydb. (Poa kingii S. Wats., Festuca kingii Cassidy, $F$. confinis Vasey)

\section{Poa L.}

$P$. bolanderi Vasey

$P$. howellii Vasey \& Scribn.

$P$. bigelovii Vasey \& Scribn.

$P$. annua $\mathrm{L}$.

P. compressa $\mathrm{L}$.

$P$. macrantha Vasey

$P$. douglasii Nees

$P$. confinis Vasey

$P$. rhizomata Hitchc.

P. atropurpurea Scribn.

$P$. nervosa (Hook.) Vasey
P. kelloggii Vasey

$P$. pratensis $\mathrm{L}$.

$P$. arctica $\mathrm{R} . \mathrm{Br}$.

$P$. trivialis $\mathrm{L}$.

P. leptocoma Trin.

P. bulbosa L.

$P$. palustris $\mathrm{L}$.

$P$. fendleriana (Steud.) Vasey

P. longiligula Scribn. \& Will.

$P$. rupicola Nash

$P$. cusickii Vasey

$P$. napensis Beetle

$P$. unilateralis Scribn.

$P$. epilis Scribn.

$P$. pringlei Scribn.

$P$. lettermani Vasey

$P$. hanseni Scribn.

P. scabrella (Thurb.) Benth.

$P$. gracillima Vasey

$P$. secunda Presl (P. sandbergii Vasey)

P. canbyi (Scribn.) Piper

$P$. nevadensis $\mathrm{Vasey}$

P. juncifolia Scribn. (P. brachyglossa Piper)

P. ampla Merr.

\section{Briza L.}

B. maxima L. •

B. minor $\mathrm{L}$.

\section{Eragrostis Beauv.}

E. oxylepis Nutt. (E. secundiflora misapplied)

E. hypnoides (Lam.) B.S.P.

E. pilosa (L.) Beauv.

E. diffusa Buckl. (E. caroliniana misapplied)

E. orcuttiana Vasey

E. lutescens Scribn.

E. cilianensis (All.) Lutati (E. megastachya (Koel.) Link)

E. poaeoides Beauv.

E. barrelieri Daveau.

E. neomexicana Vasey

E. mexicana (Hornem.) Link

E. arida Hitchc.

Dissanthelium Trin.

D. californicum (Nutt.) Benth.

\section{Monanthochloe Engelm.}

M. littoralis Engelm. 
Distichlis Raf.

D. spicata (L.) Greene

var. nana Beetle

D. stricta (Torr.) Rydb. (D. dentata Rydb., pistillate plant)

\section{Dactylis L.}

D. glomerata L.

\section{Cynosurus L.}

C. echinatus $\mathrm{L}$.

\section{Lamarckia Moench (Achyrodes} Boehmer)

L. aurea (L.) Moench

\section{Arundo L.}

A. donax $\mathrm{L}$.

\section{Cortaderia Stapf}

C. selloana (Schult.) Aschers. \& Graeb.

\section{Ampelodesmos Beauv.}

A. mauritanicus (Poir.) Dur. \& Schinz.

\section{Phragmites L.}

$P$. communis Trin.

\section{Melica L.}

$M$. aristata Thurb.

M. harfordii Boland.

M. subulata (Griseb.) Scribn.

$M$. geyeri Munro

var. aristulata J. T. Howell

M. spectabilis Scribn.

M. bulbosa Geyer (M. bella Piper)

$M$. fugax Boland.

M. inflata (Boland.) Vasey

$M$. stricta Boland.

M. torreyana Scribn.

M. imperfecta Trin.

var. refracta Thurb.

var. flexuosa Boland.

var. minor Scribn.

$M$. frutescens Scribn.

M. californica Scribn. (M. bulbosa

Geyer ex Thurb.)

var. nevadensis Boyle

\section{Ectosperma Swallen}

E. alexandrae Swallen

Tridens Roem. \& Schult. (formerly included in Triodia R. Br.)

T. pulchellus (H.B.K.) Hitchc.

T. muticus (Torr.) Nash
Neostapfia Davy (formerly included in Anthochloa Nees)

N. colusana (Davy) Davy

Orcuttia Vasey

O. greenei Vasey

O. californica Vasey var. inaequalis (Hoover) Hoover var. viscida Hoover

O. tenuis Hitchc.

O. pilosa Hoover

Blepharidachne Hack.

B. kingii (S. Wats.) Hack.

\section{HORDEAE}

\section{Agropyron Gaertn.}

A. cristatum (L.) Gaertn.

A. desertorum (Fisch.) Schult.

A. repens (L.) Beauv.

A. smithii Rydb.

A. subsecundum (Link) Hitchc. ( $A$. caninum misapplied)

A. trachycaulum (Link) Malte ( $A$. tenerum Vasey, $A$. pauciflorum (Schwein.) Hitchc.)

A. pringlei (Scribn. \& Smith) Hitchc.

A. scribneri Vasey

A. spicatum (Pursh) Scribn. \& Smith

A. arizonicum Scribn. \& Smith var. laeve Scribn. \& Smith (A. laeve Hitchc.)

A. saxicola (Scribn. \& Smith) Piper

A. saundersii (Vasey) Hitchc.

\section{Aegilops L.}

A. triuncialis $\mathrm{L}$.

\section{Elymus L.}

E. caput-medusae L.

E. mollis Trin.

E. vancouverensis Vasey

E. triticoides Buckl.

var. pubescens Hitchc. var. multiflorus Gould.

E. simplex Scribn. \& Will. (E. triticoides var. simplex Hitchc.)

E. pacificus Gould (Agropyron arenicola Davy)

E. salinus Jones

E. condensatus Presl

E. cinereus Scribn. \& Merr.

E. glaucus Buckl. var. jepsoni Davy 
E. virescens Piper

E. macounii Vasey

E. aristatus Merr.

E. canadensis L.

\section{Sitanion Raf.}

S. hanseni (Scribn.) J. G. Smith (S. anomalum J. G. Smith)

S. jubatum J. G. Smith

S. hystrix (Nutt.) J. G. Smith

\section{Hystrix Moench}

H. californica (Boland.) Kuntze

\section{Hordeum L.}

H. jubatum L.

H. brachyantherum Nevski (H. boreale Scribn. \& Smith; H. nodosum var. boreale (S. \& S.) Hitchc.; $H$. nodosum misapplied)

H. californicum Covas \& Stebbins

H. depressum (Scribn. \& Smith) Rydb.

H. pusillum Nutt.

H. hystrix Roth. (H. gussonianum Parl.)

H. arizonicum Covas (Yuma Field Sta., Bard Cal., one specimen only)

$H$. leporinum Link. (H. murinum misapplied)

H. stebbinsii Covas

\section{Lolium L.}

L. perenne $\mathrm{L}$.

L. multiflorum Lam.

L. temulentum $\mathrm{L}$.

L. strictum Presl

\section{Monerma Beauv.}

M. cylindrica (Willd.) Coss. \& Dur. (Lepturus cylindricus (Willd.) Trin.)

\section{Parapholis C. E. Hubb.}

P. incurva (L.) C. E. Hubb. (Pholiurus incurvus (L.) Schinz. \& Thell.)

\section{Scribneria Hack.}

S. bolanderi (Thurb.) Hack.

\section{AVENEAE}

\section{Schismus Beauv.}

S. barbatus (L.) Thell.

S. arabicus Nees

\section{Koeleria Pers.}

K. cristata (L.) Pers.

K. phleoides (Vill.) Pers.
Sphenopholis Scribn.

S. obtusata (Michx.) Scribn. (S. obtusata var. lobata Scribn.)

\section{Trisetum Pers.}

T. wolfii Vasey

T. cernuum Trin.

T. spicatum (L.) Richt. (T. congdonii Scribn. \& Merr.; T. sesquiflorum misapplied)

T. canescens Buckl.

$T$. flavescens (L.) Beauv.

\section{Deschampsia Beauv.}

D. danthonioides (Trin.) Munro (Aira danthonioides Trin.)

D. elongata (Hook.) Munro (Aira elongata Hook.)

D. atropurpurea (Wahl.) Scheele

D. caespitosa (L.) Beauv. (Aira caespitosa L.)

D. holciformis Presl (Aira holciformis (Presl) Steud.)

\section{Aira L. (Aspris Adans.)}

A. praecox $\mathrm{L}$.

A. caryophyllaa $\mathrm{L}$.

A. elegans Willd.

\section{Avena $\mathbf{L}$.}

1. fatua $\mathrm{L}$.

A. barbata Brot.

\section{Arrhenatherum Beauv.}

A. elatius (L.) Presl var. bulbosum (Willd.) Spenner.

Holcus L. (Notholcus Nash)

H. lanatus $\mathrm{L}$.

H. mollis $\mathrm{L}$.

Danthonia Lam. \& DC.

D. intermedia Vasey

D. californica Boland.

var. americana (Scribn.) Hitchc.

(D. americana Scribn.)

D. unispicata (Thurb.) Munro

D. pilosa R. Br. (escaped from cultivation)

D. semiannularis (Labill.) R. Br. (escaped from cultivation)

\section{AGROSTIDEAE}

\section{Calamagrostis Adans.}

C. bolanderi Thurb.

C. breweri Thurb.

C. foliosa Kearney 
C. purpurascens $\mathrm{R}$. Br.

C. rubescens Buckl.

C. nutkaensis (Presl) Steud.

C. densa Vasey

C. koeleroides Vasey

C. canadensis (Michx.) Beauv.

C. inexpansa A. Gray

C. californica Kearney

C. crassiglumis Thurb.

\section{Ammophila Host.}

A. arenaria (L.) Link

\section{Agrostis L.}

A. avenacea $\mathrm{Gmel}$. (A. retrofracta Willd.)

A. hooveri Swallen

A. thurberiana Hitchc.

A. semiverticillata (Forsk.) C. Christ. (A. verticillata Vill.)

A. palustris Huds. (A. maritima Lam.)

A. alba L.

A. tenuis Sibth. var. aristata (Parn.) Druce

A. humilis Vasey

A. exigua Thurb.

A. hendersoni Hitchc.

A. kennedyana Beetle

A. microphylla Steud. (A. exarata var. monolepis misapplied)

A. aristiglumis Swallen

A. hallii Vasey var. pringlei (Scribn.) Hitchc.

A. hooveri Swallen

A. lepida Hitchc.

A. pallens Trin.

A. diegoensis $\mathrm{V}$ asey

A. blasdalei Hitchc. (A. breviculmis misapplied)

A. variabilis Rydb. (formerly included in $A$. rossae Vasey)

A. exarata Trin.

var. pacifica Vasey

var. monolepis (Torr.) Hitchc.

A. ampla Hitchc.

A. scabra Willd. (formerly included in A. hiemalis Walt.)

A. idahoensis Nash

A. oregonensis Vasey

A. longiligula Hitchc.

\section{Cinna L.}

C. latifolia (Trevir.) Griseb.

\section{Alopecurus L.}

A. pallescens Piper

A. aequalis Sobol.

A. geniculatus L.

A. carolinianus Walt.

A. howellii Vasey

A. myosuroides Huds.

A. saccatus Vasey

\section{Polypogon Desf.}

$P$. monspeliensis (L.) Desf.

$P$. maritimus Willd.

$P$. interruptus H.B.K. (P. lutosus misapplied)

\section{Phleum L.}

$P$. pratense $\mathrm{L}$.

$P$. alpinum $\mathrm{L}$.

\section{Gastridium Beauv.}

G. ventricosum (Gouan) Schinz \& Thell.

\section{Lagurus L.}

L. ovatus L.

\section{Muhlenbergia Schreb.}

M. minutissima (Steud.) Swallen (Sporobolus minutissimus (Steud.) Hitchc.; S. microspermus and $S$. confusus misapplied)

M. microsperma (DC) Kunth

$M$. filiformis (Thurb.) Rydb.

M. utilis (Torr.) Hitchc. (M. repens misapplied to California plants)

M. richardsonis (Trin.) Rydb. ( $M$. squarrosa (Trin.) Rydb.)

M. glauca (Nees) Mez (M. lemmoni Scribn.)

M. asperifolia (Nees \& Mey.) Parodi (Sporobolus asperifolius Nees \& Mey.)

M. andina (Nutt.) Hitchc.

M. californica Vasey

M. mexicana (L.) Trin. forma setiglumis (S. Wats.) Fernald (M. foliosa var. setiglumis (S. Wats.) Scribn.)

M. jonesii (Vasey) Hitchc.

M. montana (Nutt.) Hitchc.

$M$. porteri Scribn.

M. rigens (Benth.) Hitchc. (Epicampes rigens Benth.)

\section{Sporobolus R. Br.}

S. flexuosus (Thurb.) Rydb.

$S$. contractus Hitchc. 
S. airoides (Torr.) Torr.

S. wrightii Munro

\section{Crypsis Ait.}

C. niliaca Fig. \& De Not. (C. aculeata misapplied)

\section{Heleochloa Host}

H. schoenoides (L.) Host

\section{Oryzopsis Michx.}

O. miliacea (L.) Benth. \& Hook.

O. kingii (Boland.) Beal

O. bloomeri (Boland.) Ricker

O. micrantha (Trin. \& Rupr.) Thurb.

O. webberi (Thurb.) Benth.

O. hymenoides (Roem. \& Schult.)

Ricker

\section{Stipa L.}

S. speciosa Trin. \& Rupr.

S. stillmanii Boland.

S. coronata Thurb.

var. depauperata (Jones) Hitchc. ( $S$. parishii Vasey)

S. comata Trin. \& Rupr.

var. intermedia Scribn. \& Tweedy

S. pulchra Hitchc.

S. cernua Stebb. \& Love

S. lepida Hitchc.

var. andersonii (Vasey) Hitchc.

S. thurberiana Piper

S. elmeri Piper \& Brodie

S. latiglumis Swallen

S. occidentalis Thurb.

S. californica Merr. \& Davy

S. lemmoni (Vasey) Scribn.

$S$. columbiana Macoun (S. minor

(Vasey) Scribn.)

var. nelsoni (Scribn.) Hitchc.

S. lettermani Vasey

S. williamsii Scribn.

S. diegoensis Swallen

$S$. pinetorum Jones

S. arida Jones

\section{Aristida L.}

A. californica Thurb.

A. glabrata (Vasey) Hitchc.

A. orcuttiana Vasey (A. schiedeana misapplied)

A. oligantha Michx.

A. adscensionis $\mathrm{L}$.

A. divaricata Humb. \& Bonpl.
A. hamulosa Henr. (A. divaricata misapplied)

A. glauca (Nees) Walp. (A. reverchoni Vasey)

A. purpurea Nutt.

A. wrightii Nash

A. longiseta Steud. var. robusta Merr.

A. fendleriana Steud.

A. parishii Hitchc.

\section{Hilaria H.B.K.}

\section{ZOYSIEAE}

H. jamesii (Torr.) Benth.

$H$. rigida (Thurb.) Benth.

\section{Leptochloa Beauv.}

\section{CHLORIDEAE}

L. filiformis (Lam.) Beauv.

L. fascicularis (Lam.) A. Gray

L. uninervia (Presl) Hitchc.

\section{Eleusine Gaertn.}

E. indica (L.) Gaertn.

\section{Dactyloctenium Willd.}

D. aegyptium (L.) Beauv.

\section{Cynodon Rich.}

C. dactylon (L.) Pers.

\section{Beckmannia Host}

B. syzigachne (Steud.) Fernald (B. erucaeformis misapplied)

\section{Spartina Schreb.}

S. foliosa Trin. (S. leiantha Benth.)

$S$. gracilis Trin.

\section{Chloris Swartz}

C. gayana Kunth

C. virgata Swartz

C. verticillata Nutt.

\section{Bouteloua Lag.}

B. aristidoides (H.B.K.) Griseb.

B. curtipendula (Michx.) Torr.

B. radicosa (Fourn.) Griffiths

B. barbata Lag. (B. arenosa Vasey)

B. rothrockii Vasey

B. hirsuta Lag.

B. gracilis (H.B.K.) Lag.

B. eriopoda (Torr.) Torr.

B. trifida Thurb.

\section{PHALARIDEAE}

\section{Hierochloe R. Br.}

$H$. occidentalis Buckl.

\section{Anthoxanthum L.}

A. odoratum L.

A. aristatum Boiss. 
Ehrharta Thunb.

E. calycina J. E. Smith

E. erecta Lam.

\section{Phalaris L.}

$P$. paradoxa L.

var. praemorsa (Lam.) Coss. \& Dur.

$P$. canariensis $\mathrm{L}$.

$P$. brachystachys Link

P. minor Retz.

$P$. caroliniana Walt.

$P$. angusta Nees

$P$. lemmoni Vasey

P. californica Hook. \& Arn.

$P$. arundinacea $\mathrm{L}$.

P. tuberosa L. var. stenoptera (Hack.)

Hitchc.

\section{Leersia Swartz}

L. oryzoides (L.) Swartz

\section{PANICEAE}

Digitaria Heist. (Syntherisma Walt.)

D. sanguinalis (L.) Scop.

D. decumbens Stent

D. ischaemum (Schreb.) Muhl.

\section{Stenotaphrum Trin.}

S. secundatum (Walt.) Kuntze

\section{Eriochloa H.B.K.}

E. aristata Vasey

E. gracilis (Fourn.) Hitchc.

\section{Paspalum L.}

$P$. distichum $\mathrm{L}$.

$P$. dilatatum Poir.

$P$. urvillei Steud. (P. larrañagai

Arech.)

\section{Panicum L.}

$P$. lindheimeri Nash

P. huachucae Ashe

$P$. occidentale Scribn.

$P$. pacificum Hitchc. \& Chase

$P$. thermale Boland.

P. shastense Scribn. \& Merr.

$P$. scribnerianum Nash

$P$. arizonicum Scribn. \& Merr.
P. dichotomiflorum Michx.

$P$. capillare $\mathrm{L}$. var. occidentale Rydb.

( $P$. barbipulvinatum Nash)

$P$. hillmani Chase

P. hirticaule Presl

$P$. miliaceum L.

$P$. agrostoides Spreng.

$P$. urvilleanum Kunth

\section{Echinochloa Beauv.}

E. colonum (L.) Link

E. crusgalli (L.) Beauv. var. zelayensis (H.B.K.) Hitchc.

Setaria Beauv. (Chaetochloa Scribn.)

S. lutescens (Weigel) Hubb.

$S$. carnei Hitchc.

S. geniculata (Lam.) Beauv.

S. verticillata (L.) Beauv.

S. viridis (L.) Beauv.

S. sphacelata (Schum.) Stapf \& C. E. Hubb.

\section{Pennisetum Rich.}

$P$. villosum $\mathrm{R}$. Br.

$P$. clandestinum Hochst.

\section{Cenchrus L.}

C. pauciflorus Benth. (C. longispinus (Hack.) Fernald)

\section{ANDROPOGONEAE \\ Imperata Cyrillo}

I. brevifolia Vasey (I. arundinacea ssp. Hookeri Rupr., I. hookeri Rupr. ex Hack.)

\section{Andropogon L.}

A. cirratus Hack.

$A$. virginicus $\mathrm{L}$.

A. glomeratus (Walt.) B.S.P.

A. barbinodis Lag. ( $A$. saccharoides misapplied)

\section{Sorghum Moench}

S. halepense (L.) Pers. (Holcus halepensis L.)

S. sudanense (Piper) Stapf (S. vulgare var. sudanense (Piper) Hitchc.) 


\section{LITERATURE CITED}

1. Abrams, LeRoy.

1923. An illustrated Flora of the Pacific states. (Grasses by Hitchcock.) Stanford University, California. 1: 103-255

2. BEETLE, A. A.

1947. Distribution of the native grasses of California. Hilgardia 17(9) : 309-57.

3. BentLEy, J. R., and M. W. Talbot.

1948. Annual-plant vegetation of the California foothills as related to range management. Ecology 29(1) : 72-79.

4. California Forest Study Committee.

1947. The forest situation in California. Calif. State Printing Office, Sacramento, California:

2: 1-57. See especially pp. 48-50.

5. Canfield, R. H.

1942. A short cut method for estimating grazing use. Southwestern Forest and Range Expt. Sta. Res. Note No. 99: 1-5.

6. Chase, Agnes.

1937. First hook of grasses. 125 p. W. A. Silveus, San Antonio, Texas.

7. Christ, J. H.

1934. Reseeding burned-over lands in northern Idaho. Idaho Agr. Expt. Sta. Bul. 201: 1-28.

8. Clark, Geo. H., and M. O. Malte.

1913. Fodder and pasture plants. Dept. of Agr. Dom. Canada: 1-143.

9. Clements, F. E.

1920. Plant indicators. Carnegie Inst. Wash. Pub. 290 : 1-388.

10. Dayton, W. A., and Associates.

1937. Range Plant Handbook. Prepared by Forest Service. 512 p. U. S. Dept. Agr. Gov.

Printing Office, Washington, D.C. Grass section: 1-125.

11. Fleming, C. E., M. A. Shipley, and M. R. Miller.

1942. Bronco grass (Bromus tectorum) on Nevada ranges. Nev. Agr. Expt. Sta. Bul. 159: 1-21.

12. Forsling, C. L. and W. A. Dayton.

1931. Artificial reseeding of western mountain range lands. U. S. Dept. Agr. Cir. 178: 1-48.

13. Gordon, A. and A. W. Sampson.

1939. Composition of common California foothill plants as a factor in range management.

Calif. Agr. Expt. Sta. Bul. 627 : 1-95.

14. Grover, D. I.

1945. Range condition, a classification of the annual forage type. 16 p. Corning S. C. District, Corning, Calif. U. S. Dept. Agr., Soil Cons. Ser., Pacific Coast Region. Processed.

15. Guilbert, H. R., G. H. Hart, K. A. Wagnon, and H. Goss.

1944. The importance of continuous growth in beef cattle. Calif. Agr. Expt. Sta. Bul. 688: 1-35.

16. Hart, G. H., H. R. Guilbert, and H. Goss.

1932. Seasonal changes in the composition of range forage and their relation to nutrition of animals. Calif. Agr. Expt. Sta. Bul. 543: 1-62.

17. Hart, G. H., and H. R. GuilberT.

1933. Vitamin-A deficiency as related to reproduction of range cattle. Calif. Agr. Expt. Sta. Bul. 560: 1-30.

18. HENDRY, G. W.

1931. The adobe brick as an historic source. Agricultural History 5(3) : 110-127.

Нiтснсоск, A. S.

19. 1914. Text-book of grasses, with especial reference to the economic species of the United States. 276 p. The Macmillan Co., New York.

20. 1935. Manual of the grasses of the United States. U. S. Dept. Agr. Misc. Publ. 200: 1-1040. (Revised by Agnes Chase [1951]: 1-1051.)

21. 1936. Genera of grasses of the United States with special reference to the economic species. U. S. Dept. Agr. Bul. 772: 1-307. (Revised by Agnes Chase.)

22. Hitch Cock, A. S. and A. Chase.

1931. Grass. Smithsn. Sci. Ser. $11: 201-250$.

23. Hopper, T. H. and L. L. NesbitT.

1930. The chemical composition of some North Dakota pasture and hay grasses. N. Dak. Agr. Expt. Sta. Bul. 236: 1-38.

24. Hormay, A. L.

1944. Moderate grazing pays. U. S. Dept. Agr., Forest Service. Leaflet No. 239: 1-8. 
25. Hormay, A. L. and A. FausetT.

1942. Standards for judging the degree of forage utilization on Calif. annual-type ranges. U. S. Dept. Agr., Calif. For. and Range Expt. Sta. Tech. Note 21 : 1-13. Processed.

26. Hull, A. C. and J. F. Pechanec.

1947. Cheatgrass-a challenge to range research. Jour. For. 45 (8) : 555-564.

27. HUMPHREY, R. R.

1947. Range forage evaluation by the range condition method. Jour. For. 45(1) : 10-16.

28. INGEL, $H$.

1908. The mineral constituents of foods. Jour. Agr. Sci. 3: 22-31.

29. Jensen, H. A.

1947. A system for classifying vegetation in California. Calif. Fish and Game 33(4) : 199-266.

30. JEPSON, WILLIS L.

1925. A manual of the flowering plants of California. 1238 p. (Grasses by Hitchcock, A. S., and Agnes Chase: 72-144.) Associated Students' Store, University of California, Berkeley, California.

31. Jones, B. J., and J. B. Brown.

1947. Irrigated pastures in California. Calif. Agr. Ext. Ser. Cir. 125: 1-48.

32. JonEs, B. J., and R. M. Love.

1945. Improving California ranges. Calif. Agr. Expt. Sta. Cir. 129: 1-48.

33. Lommasson, $\mathrm{T}$.

1939. The significance of the spread of Sandberg bluegrass as a result of the drought period, 1931-1936. U. S. Forest Service Northern Region. (Dev. in R. Mgt.) No. 1 : 1-4. Mimeographed.

34. Lommasson, T., and C. JENSEN.

1943. Determining utilization of range grasses from height-weight tables. Jour. For. 41 (8) : $589-93$.

35. Love, R. M.

1947. Interspecific and intergeneric hybridization in forage crop improvement. Jour. Am. Soc. Agron. 39(1) : 41-46.

36. Love, R. M., and B. J. Jones.

1947. Improving California brush ranges. Calif. Agr. Expt. Sta. Cir. 371 : 1-31.

37. McCarty, Edward C.

1938. The relation of growth to the varying carbohydrate content in mountain brome. U. S. Dept. Agr. Tech. Bul. 598: 1-24.

38. MilleR, R. F.

1942. Sheep production in California. Calif. Agr. Expt. Sta. Cir. 49: 1-79.

39. Morrison, F. B.

1937. Feeds and feeding. Twentieth edition. 1050 p. Morrison Pub. Co., Ithaca, N.Y.

40. Parker, K. W., and P. V. Woodhead.

1944. What's your range condition. Amer. Cattle Producer 26 (6) : 8, 9, 11.

41. Pechanec, J. F. and G. D. Pickford.

1937. A comparison of some methods used in determining percentage utilization of range grasses. Jour. Agr. Res. 54(10) : 753-65.

42. Pickford, G. D. and E. H. Reid.

1942. Basis for judging subalpine grassland ranges of Oregon and Washington. U. S. Dept. Agr. Cir. 655: 1-37.

43. PIPER, C. V.

1922. Important cultivated grasses. U. S. Dept. Agr. Farmers' Bul. 1254: 1-38.

44. REID, E. H. and G. D. PickFoRD.

1946. Judging mountain meadow range condition in eastern Oregon and eastern Washington. U. S. Dept. Agr. Cir. 748: 1-31.

45. Robbins, W. W., M. K. Bellue, and W. S. Ball.

1941. Weeds of California. 491 p. State Dept. Agr., Sacramento, California.

46. Rogers, J. B.

1945. Range condition, a classification of the annual grass-weed forage type. Contra Costa S. C. District, Walnut Creek, Calif. 9 p. U. S. Dept. Agr., Soil Conservation Service, Pacific Coast Region. Processed.

47. Sampson, A. W.

1914. Natural revegetation of range lands based upon growth requirements and life history of the vegetation. Jour. Agr. Res. 3(2) : 93-147. 
48. 1917. Important forage plants, their life history and forage value. U. S. Dept. Agr. Bul. 545: $1-63$.

49. 1919. Plant succession in relation to range management. U. S. Dept. Agr. Bul. 791 : 1-76.

50. 1932. The forage value of Pahute weed (Suaeda depressa) in Goose Lake. Preliminary report: p. 7. School of Forestry Library, Berkeley, California.

51. 1944. Plant succession on burned chaparral lands in northern California. Calif. Agr. Expt. Sta. Bul. 685 : 1-144.

52. Sampson, A. W. and A. Chase.

1927. Range grasses of California. Calif. Agr. Exp. Sta. Bul. 430: 1-94.

53. Sampson, A. W. and E. C. McCarty.

1930. The carbohydrate metabolism of Stipa pulchra. Hilgardia 5(4) : 61-100.

54. Stanley, E. B. and C. W. Hodgson.

1938. Seasonal changes in the chemical composition of some important Arizona range grasses. Ariz. Agr. Expt. Sta. Tech. Bul. 73: 451-66.

55. Stebbins, G. L., Jr.

1947. Improved forage grasses to be put to field trials. California Agriculture 1 (4) : 1-2.

56. Stebins, G. L. JR., and R. M. Love.

1941. An undescribed species of Stipa from California. Madrono 6(4) : 137-41.

57. Stewart, G., R. H. Walker, and R. Price.

1939. Reseeding range lands of the intermountain region. U. S. Dept. Agr. Farmers' Bul. 1823: 1-25.

58. Stoddart, L. A.

1946. Some physical and chemical responses of Agropyron spicatum to herbage removal at various seasons. Utah Agr. Expt. Sta. Bul. 324: 1-24.

59. Stoddart, L. A. and J. E. Greaves.

1942. The composition of summer range plants in Utah. Utah Agr. Expt. Sta. Bul. 305: 1-22. 60. TаLвOT, M. W.

1937. Indicators of southwestern range conditions. U. S. Dept. Agr. Farmers' Bul. 1782: 1-35.

61. TALbot, M. W. and H. H. Biswell.

1942. The forage crop and its management. In: Hutchison, C. B., and E. I. Kotok. The San Joaquin experimental range. Calif. Agr. Expt. Sta. Bul. 663: 13-49.

62. Talbot, M. W. and A. L. Hormay.

1945. First-season records of cattle weights from a pine-timber range and a mountain meadow range. Calif. For. and Range Expt. Sta. Res. Note 44: 1-8.

63. THORNBER, J. J.

1910. The grazing ranges of Arizona. Ariz. Agr. Expt. Sta. Bul. 65: 245-360.

64. Valentine, K. A.

1946. Determining the grazing use of grasses by scaling. Jour. For. 44(7) : 528-30.

65. Young, V. A.

1945. Proper grazing use on southern California annual range. 11 p. U. S. Dept. Agr., Soil Conservation Service, Region Seven. Processed. 


\section{A LIST OF TECHNICAL WORDS USED IN THIS BULLETIN, AND THEIR MEANINGS}

Acuminate. Gradually tapering to a sharp point. Compare acute.

Acute. Sharp-pointed, but less tapering than acuminate.

Apex. Summit, tip.

Appressed. Lying against an organ. The branches of an inflorescence may be appressed to the main axis or the hairs on a stem may be appressed to the surface.

Articulate. Jointed. Certain spikelets are articulate with the pedicel; certain awns with the lemma.

Attenuate. Gradually narrowed to a slender apex or base.

Auricle. An ear. Applied to earlike lobes at the base of blades and to the small lobes at the summit of the sheath in Hordeae.

Awn. A slender bristle at the end (rarely on the back or edge) of an organ. In grasses the awn is usually a continuation of the midnerve (sometimes also of the lateral nerves) of the glumes or lemmas, rarely of the palea.

Axil. The angle between an organ and its axis. Applied especially to the angle between a leaf and its stem and between a branch or pedicel and its axis. Axillary. Growing in an axil.

Axis. The main stem of an inflorescence, especially of a panicle. Compare rachis.

Base. Lowest part, at the base of an organ.

Blade. The part of the leaf above the sheath.

Callus. A thickened part. The indurate downward extension of the mature lemma in Stipa, Aristida, and some other genera. Structurally such a callus is part of the rachilla. In some Andropogoneae the callus is an oblique part of the rachis which extends downward from the spikelet. Callus hairs. The hairs at the base of the floret of Calamagrostis and some other genera.

Canescent. Gray-pubescent or hairy.

Capillary. Very slender or hairlike.

Ciliate. Fringed with hairs on the margin (like an eyelash).

Cleistogamous. Applied to flowers or florets when fertilized without opening.

Compressed. Flattened laterally, as of spikelets or sheaths. If the organ is also sharply keeled, it is said to be compressed-keeled.

Continuous. Said of the rachis or other organ which does not disarticulate. The opposite of articulate or disarticulating.
Convolute. Rolled longitudinally. Said mostly of blades, one edge being inside and the other outside.

Coriaceous. Leathery in texture.

Culm. The jointed stem of grasses.

Decumbent. Reclining on the ground, but with ascending apex. Said of stems or culms.

Digitate. Several members arising from the summit of a support. Said especially of racemes or spikes from the summit of a peduncle, as in Digitaria or Cynodon.

Disarticulating. Separating at maturity. Compare articulate.

Distant. Set apart, not close together.

Divaricate. Widely and stiffly divergent as the branches of certain open panicles, e.g. Oryzopsis hymenoides.

Dorsal. Relating to the back of an organ.

Elliptic. Shaped like an ellipse. Said of blades and other flat surfaces.

Erose. Irregularly notched at apex as if gnawed. Said of glumes and lemmas.

Exserted. Protruding. The awns of some species of Calamagrostis are exserted, protruding beyond the spikelet.

Fascicle. A little bundle or cluster. Said of clustered leaves, branches of a panicle, and spikes or racemes on an axis.

Filiform. Threadlike.

Flexuous. Bent alternately in opposite directions.

Floret. The lemma and palea with included flower (stamens and pistil). Florets may be perfect, staminate, pistillate, neuter, sterile, and so on.

Floriferous. Bearing flowers (florets).

Fusiform. Spindle-shaped.

Geniculate. Bent abruptly. Said of awns and the lower nodes of the culm.

Glabrous. Without hairs.

Glaucous. Covered with a waxy coating that gives a bluegreen color, as in the leaf of the cabbage or the bloom of the grape.

Glumes. The pair of bracts at the base of a spikelet.

Hispid. Pubescent with stiff or rigid hairs.

Imbricate. Overlapping, as the lemmas in many spikelets.

Indurate. Hard.

Inflorescence. The flowering part of a plant.

Internode. The part of a stem between two successive nodes. 
Interrupted. The continuity broken. Said especially of dense inflorescences whose continuity is broken by gaps.

Involute. Rolled inward from the edges, the upper surface within. Said of blades.

Keel. The sharp fold at the back of a compressed sheath, blade, glume, or lemma. The palea and sometimes the glumes and lemmas may be two-keeled. Keel is used because of the similarity to the keel of a boat.

Lemma. The bract of a spikelet above the pair of glumes.

Ligule. The thin appendage on the inside of a leaf at the junction of sheath and blade.

Lobe. A segment of an organ, usually rounded or obtuse. Applied especially to the divisions of a cleft lemma. Lobed, with lobes.

Mucronate. Provided with a mucro, or minute awn or excurrent midnerve of an organ.

Nerved. Having nerves, the vascular veins (mostly longitudinal) of the blades, glumes, and lemma.

Neuter. Without stamens or pistils. Said of florets or spikelets.

Nodulose. Roughened with minute knobs.

Obovate. Inversely egg-shaped (i.e., inversely shaped like the longitudinal section of an egg).

Obtuse. Rounded at the apex. Contrasted with acute.

Palea. The inner bract of a floret.

Panicle. An inflorescence with a main axis and subdivided branches. It may be compact and spikelike, or open.

Pedicel. The stalk of a spikelet.

Peduncle. The stalk or stem of an inflorescence.

Perfect. Applied to flowers having both stamens and pistils.

Persistent. Remaining attached, either after other parts have been shed, or for a considerable period. The paleas of certain species of Eragrostis persist after the fall of the lemmas.

Pilose. Pubescent with soft straight hairs.

Pistillate. Applied to flowers bearing pistils only and to an inflorescence or a plant with pistillate flowers.

Plumose. Feathered, having fine hairs on each side. Said chiefly of awns.

Puberulent. Diminutive of pubescent. Minutely pubescent.

Pubescent. Covered with hairs. Applied especially when the hairs are short and soft.

Raceme. An inflorescence in which the spikelets are pediceled on a rachis. Racemose. In racemes.
Rachilla. A small rachis. Applied especially to the axis of a spikelet.

Rachis. The axis of a spike or raceme.

Reflexed. Bent backward.

Rhizome. An underground stem; rootstock. The rhizomes of grasses are usually slender and creeping. They bear scales at the nodes.

Saccate. Bag or sac-shaped.

Scaberulous. Minutely scabrous.

Scabrid, scabrous. Rough to the touch. Covered with minute points, teeth, or very short stiff hairs.

Serrate. Saw-toothed. Having sharp teeth.

Sessile. Without a pedicel or stalk. The opposite of pediceled. Said of blades, spikelets, and other organs.

Setaceous. Bristlelike.

Sheath. The lower part of the leaf that encloses the stem.

Sod. Turf, the stratum of soil filled with roots of grasses and herbs.

Spike. An unbranched inflorescence in which the spikelets are sessile on a rachis.

Spikelet. The unit of inflorescence in grasses, consisting of two glumes and one or more florets.

Stamen. The part of the flower that bears the pollen. Staminate. Containing stamens only. Also applied to an inflorescence or a plant with staminate flowers.

Sterile. Without pistils. A sterile floret may be staminate or neuter. It may even lack a palea, and consist of nothing but a lemma.

Stipe. A minute stalk to an organ. Applied especially to a pistil. Also sometimes to the prolongation of a rachilla as in Calamagrostis.

Stolon. A modified propagating stem above ground creeping and rooting or curved over and rooting at the tip. Stoloniferous. Bearing stolons.

Teeth. Pointed lobes or divisions.

Terete. Cylindric and slender, as the usual unflattened stems or culms of grasses.

Truncate. Ending abruptly, as if cut off horizontally.

Turgid. Swollen.

Villous. Pubescent with long soft hairs.

Webbed. Having a cluster of slender soft hairs at the base of the floret, as in certain species of Poa.

Whorl. A cluster of several branches about the axis of an inflorescence. 


\section{INDEX TO CALIFORNIA RANGE FORAGE GRASSES}

This index includes all grasses described in the section "Important Range Forage Grasses," pp. 31-115. The grasses are listed by both their botanical and common names.

For a checklist of all grasses growing naturally in California, see pp. 116-122.

Aegilops triuncalis, 73

Agropyron cristatum, 65

A. desertorum, 65

A. spicatum, 63

A. subsecundum, 64

A. trachycaulum, 64

Agrostis alba, 84

A. diegoensis, 85

A. exarata, 83

A. hallii, 85

A. palustris, 84

A. scabra, 86

A. variabilis, 85

Alaska melicgrass, 58

Alkali sacaton, 99

Alkaligrass, 62

Alpine sheep fescue, 45

Alpine timothy, 95

American oatgrass, 77

Andropogon barbinodis, 114

Annual bluegrass, 53

Annual hairgrass, 79

Anthoxanthum odoratum, 110

Aristida hamulosa, 102

A. oligantha, 102

Arizona threeawn, 102

Arrhenatherum elatius, 81

Ashy wild-rye, 67

Australian chess, 39

Australian oatgrass, 77

Avena barbata, 75

A. fatua, 74

Awned melicgrass, 56

Barleygrass, 70

Barb goatgrass, 73

Barnyardgrass, 112

Bearded wheatgrass, 64

Beardless wild-rye, 66

Beckmannia syzigachne, 107

Bentgrass, 83

Bermudagrass, 107

Big galletagrass, 105

Big squirreltail, 68

Big wild-rye, 67

Bluebunch wheatgrass, 63

Blue grama, 106

Bluegrass, 47

Bluejoint, 94

Blue wild-rye, 66

Bottlebrush, 69

Bouteloua barbata, 106

B. gracilis, 106
Brewer reedgrass, 92

Bromegrass, 34

Bromus arenarius, 39

B. carinatus, 36

B. catharticus, 36

B. inermis, 37

B. laevipes, 38

B. mollis, 39

B. orcuttianis, 38

$B$. rigidus, 40

B. rubens, 40

B. stamineus, 37

B. suksdorfii, 39

B. tectorum, 41

B. vulgaris, 38

Bulbous melicgrass, 57

Bush muhly, 98

Calamagrostis breweri, 92

C. canadensis, 94

C. purpurascens, 93

C. rubescens, 93

California bottlebrush, 69

California bromegrass, 36

California canarygrass, 109

California fescue, 46

California hairgrass, 78

California melicgrass, 57

California needlegrass, 90

California oatgrass, 77

Canada bluegrass, 50

Canarygrass, 109

Cane beardgrass, 114

Cheatgrass (downy chess), 41

Chloris gayana, 108

C. virgata, 108

Cinna latifolia, 103

Club canarygrass, 110

Columbia needlegrass, 89

Common timothy, 96

Creeping bent, 84

Creeping lovegrass, 61

Crested wheatgrass, 65

Cynodon dactylon, 107

Dactylis glomerata, 60

Dallisgrass, 111

Danthonia californica, 77

D. californica var. americana, 77

D. intermedia, 76

D. pilosa, 77

D. unispicata, 77

Darnel, 73 
Deergrass, 99

Deschampsia caespitosa, 78

D. danthonioides, 79

D. holciformis, 78

Desert needlegrass, 90

Desert saltgrass, 54

Desert wheatgrass, 65

Devilgrass (ripgut), 40

Distichlis spicata, 54

D. stricta, 54

Downy chess, 41

Drooping woodreed, 103

Dwarf muhly, 97

Echinochloa crusgalli, 112

Ehrharta calycina, 110

E. erecta, 110

Elymus caput-medusae, 67

E. cinereus, 67

E. condensatus, 67

E. glaucus, 66

E. triticoides, 66

Eragrostis hypnoides, 61

European foxtail, 47

False foxtail fescue, 47

Feather fingergrass, 108

Fendler bluegrass (muttongrass), 50

Fescuegrass, 42

Festuca arundinacea, 45

F. californica, 46

F. dertonensis, 47

F. idahoensis, 43

F. megalura, 47

F. Myuros, 47

F. occidentalis, 44

$F$. ovina var. brachyphylla, 45

F. viridula, 44

Fingergrass, 108

Foothill needlegrass, 89

Foxtail barley, 71

Foxtail chess (red bromegrass), 40

Foxtail fescue, 47

Gastridium ventricosum, 104

Glyceria borealis, 60

G. elata, 59

Goatgrass, 73

Gramagrass, 106

Greenleaf fescue, 44

Hairgrass, 77

Hall's redtop, 85

Hansen bluegrass, 52

Hansen squirreltail, 68

Hardinggrass, 109

Harford melicgrass, 57

Harlan bromegrass, 37

Hilaria rigida, 105

Holcus lanatus, 81

Hordeum brachyantherum, 70
H. hystrix, 72

H. jubatum, 71

H. leporinum, 71

Hystrix californica, 69

Idaho fescue, 43

Indian ricegrass, 100

Italian (annual) ryegrass, 72

Johnsongrass, 114

June bromegrass (downy chess), 41

Junegrass, 79

Kentucky bluegrass, 49

Kikuyu grass, 113

King ricegrass, 101

Knotgrass, 111

Koeleria cristata, 79

Large needlegrass, 91

Leafy veldtgrass, 110

Leafy redtop, 85

Lemmon needlegrass, 91

Lolium multiflorum, 72

L. perenne, 72

L. temulentım, 73

Lovegrass, 61

Mannagrass, 59

Mat muhly, 97

Meadow barley, 70

Mediterranean barley, 72

Medusa-head, 67

Melica aristata, 56

M. bulbosa, 57

M. californica, 57

M. fugax, 57

M. harfordii, 57

M. imperfecta, 56

M. stricta, 58

M. subulata, 58

M. torreyana, 58

Melicgrass, 54

Mountain redtop, 85

Mouse barley, 71

Muhlenbergia asperifolia, 98

M. filiformis, 99

M. rigens, 99

$M$. richardsonis, 97

M. porteri, 98

Muhlygrass, 96

Mutton bluegrass (muttongrass), 50

Muttongrass, 50

Narrow-flowered bromegrass, 38

Needle-and-thread, 90

Needle bromegrass (ripgut), 40

Needlegrass, 86

Nevada bluegrass, 52

Nitgrass, 104

Nodding melicgrass, 58 
Nodding needlegrass, 88

Nodding trisetum, 80

Northern mannagrass, 60

Nuttall alkaligrass, 62

Oatgrass, 75

Olney bluegrass, 51

One-spike oatgrass, 77

Orchardgrass, 60

Orcutt bromegrass, 38

Oryzopsis hymenoides, 100

O. kingii, 101

O. miliacea, 101

Pacific bluegrass, 52

Pacific panicum, 112

Panicum pacificum, 112

Paspalum dilatatum, 111

$P$. distichum, 111

Perennial ryegrass, 72

Pennisetum clandestinum, 113

Phalaris californica, 109

P. paradoxa var. praemorsa, 110

P. tuberosa var. stenoptera, 109

Phleum alpinum, 95

$P$. pratense, 96

Pine bluegrass, 51

Pine reedgrass, 93

Plumed beardgrass (cane beardgrass), 114

Poa annua, 53

P. compressa, 50

P. epilis, 52

P. fendleriana, 50

$P$. gracillima, 52

P. hanseni, 52

P. nervosa, 51

$P$. nevadensis, 52

P. olneyae (Olney bluegrass), 51

P. pratensis, 49

P. pringlei, 52

P. scabrella, 51

Poison darnel (darnel), 73

Porcupinegrass, 89

Porter muhly (bush muhly), 98

Prairie threeawn, 102

Pringle bluegrass, 52

Puccinellia airoides, 62

Purple needlegrass, 88

Purple reedgrass, 93

Red bromegrass, 40

Redtop, 83, 84

Reedgrass, 91

Rescuegrass, 36

Rhodesgrass, 108

Ricegrass, 100

Ripgut, 40

Rough-leaved dropseed, 98

Ryegrass, 72

Saltgrass, 53,54

Sitanion hanseni, 69
S. hystrix, 68

S. jubatum, 68

Six weeks fescue, 47

Six weeks grama, 106

Skyline bluegrass, 52

Slender muhly, 99

Slender wheatgrass, 64

Slender wild oats, 75

Sloughgrass, 107

Small-flowered melicgrass, 56

Small melicgrass, 57

Small needlegrass, 89

Smilo, 101

Smooth bromegrass, 37

Soft chess, 39

Sorghum halepense, 114

Spike redtop, 83

Spike trisetum, 80

Sporobolus airoides, 99

Squirreltail, 68

Stipa, 86

Stipa californica, 90

S. cernua, 88

S. columbiana, 89

S. comata, 90

S. coronata, 91

S. lemmoni, 91

S. lepida, 89

S. occidentalis, 89

S. pulchra, 88

S. speciosa, 90

S. thurberiana, 90

Suksdorf bromegrass, 39

Sweet vernalgrass, 110

Tall fescue, 45

Tall hairgrass, 81

Tall mannagrass, 59

Tall oatgrass, 81

Threeawn, 102

Thurber's needlegrass, 90

Ticklegrass, 86

Timber oatgrass, 76

Timothy, 95

Torrey melicgrass, 58

Trisetum, 79

Trisetum canescens, 81

T. cernuum, 80

T. spicatum, 80

Tufted hairgrass, 78

Veldtgrass, 110

Velvetgrass, 81

Western fescue, 44

Western needlegrass, 89

Wheatgrass, 63

Wild oats, 74

Wild-rye grass, 65

Woodland bromegrass, 38

Woodreed, 103 
The authors wish to make grateful acknowledgment to the following persons for their help in preparing this bulletin: To Aida Montier, for a number of the grass drawings and other sketches; to Dr. David D. Keck of the Carnegie Institution of Washington, Division of Plant Pathology, for his preparation of the key to the genus Poa and all systematic consideration of this genus; and to Dr. R. E. Storie, Division of Soil Science of the University, for his discourse on grassland soils.

In checking distributions and verifying data, the authors have made effective use of the grass herbarium of the U. S. National Herbarium and the herbarium of the University of California at Berkeley. The distribution maps are based upon the collections in these herbaria. A good many of the illustrations were lent by the U. S. Department of Agriculture. 
